\title{
Geologic Field-Trip Guide to the Volcanic and Hydrothermal Landscape of the Yellowstone Plateau
}

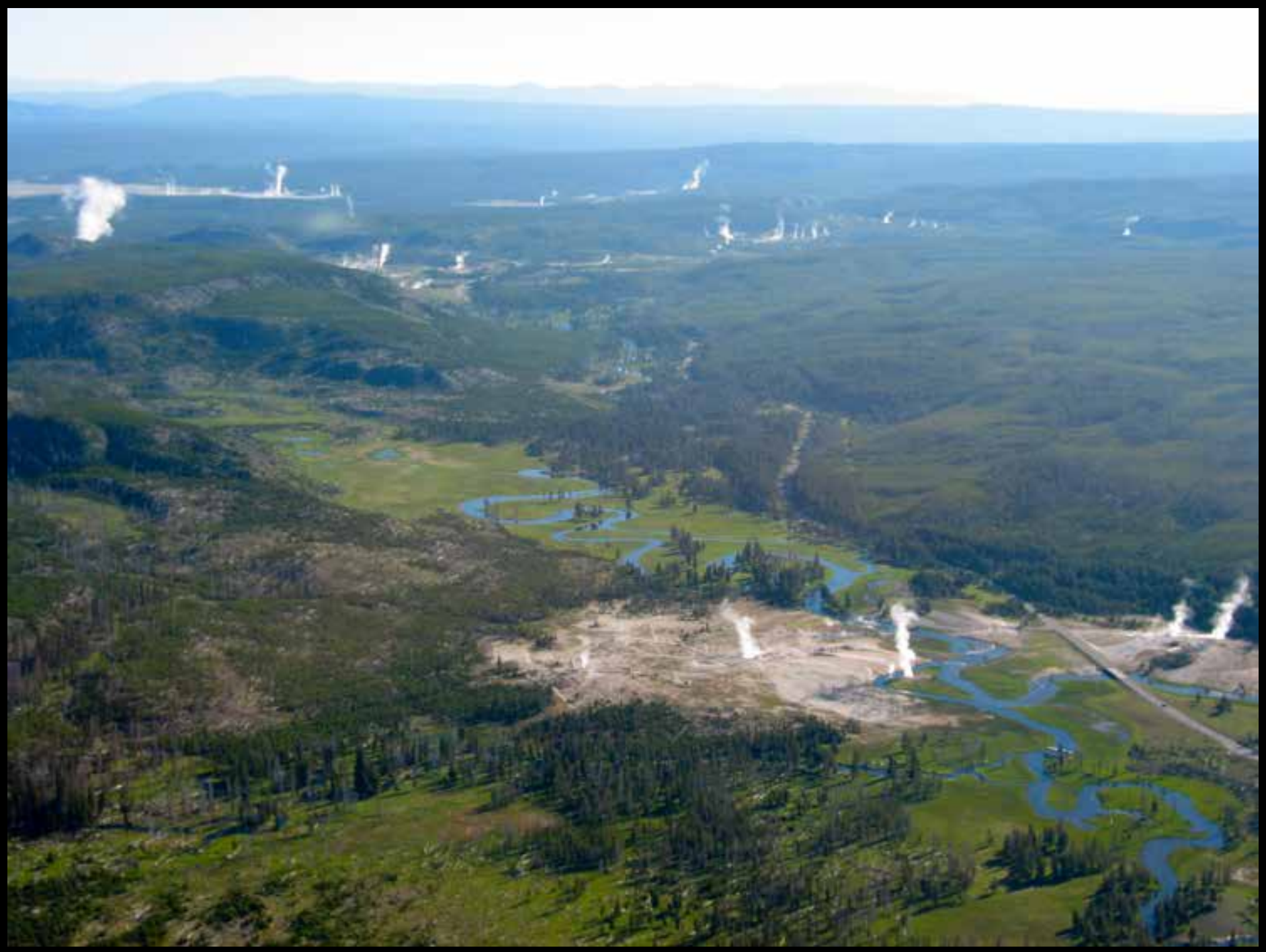

Scientific Investigations Report 2017-5022-P 
Cover: View north over Biscuit Basin in Yellowstone National Park's Upper Geyser Basin. The Firehole River flows north into the Midway and Lower Geyser Basins in the background. Near Biscuit Basin, the river occupies the area between the South Biscuit Basin and West Yellowstone rhyolite lava flows to the west and the Mallard Lake rhyolite flow to the east. U.S. Geological Survey photo by Ken McGee, 2006. 


\section{Geologic Field-Trip Guide to the Volcanic and Hydrothermal Landscape of the Yellowstone Plateau}

By Lisa A. Morgan, W.C. Pat Shanks, Jacob B. Lowenstern, Jamie M. Farrell, and Joel E. Robinson

Scientific Investigations Report 2017-5022-P 


\title{
U.S. Department of the Interior \\ RYAN K. ZINKE, Secretary
}

\section{U.S. Geological Survey William H. Werkheiser, Acting Director}

\author{
U.S. Geological Survey, Reston, Virginia: 2017
}

For more information on the USGS - the Federal source for science about the Earth, its natural and living resources, natural hazards, and the environment-visit https://www.usgs.gov or call 1-888-ASK-USGS.

For an overview of USGS information products, including maps, imagery, and publications, visit https://store.usgs.gov.

Any use of trade, firm, or product names is for descriptive purposes only and does not imply endorsement by the U.S. Government.

Although this information product largely is in the public domain, it may also contain copyrighted materials as noted in the text. Permission to reproduce copyrighted items must be secured from the copyright owner.

Suggested citation:

Morgan, L.A., Shanks, W.C.P., Lowenstern, J.B., Farrell, J.M., and Robinson, J.E., 2017, Geologic field-trip guide to the volcanic and hydrothermal landscape of the Yellowstone Plateau: U.S. Geological Survey Scientific Investigations Report 2017-5022-P, 100 p., https://doi.org/10.3133/sir20175022P.

ISSN 2328-0328 (online) 


\section{Preface}

The North American Cordillera is home to a greater diversity of volcanic provinces than any comparably sized region in the world. The interplay between changing plate-margin interactions, tectonic complexity, intra-crustal magma differentiation, and mantle melting have resulted in a wealth of volcanic landscapes. Field trips in this series visit many of these landscapes, including (1) active subduction-related arc volcanoes in the Cascade Range; (2) flood basalts of the Columbia Plateau; (3) bimodal volcanism of the Snake River Plain-Yellowstone volcanic system; (4) some of the world's largest known ignimbrites from southern Utah, central Colorado, and northern Nevada; (5) extension-related volcanism in the Rio Grande Rift and Basin and Range Province; and (6) the spectacular eastern Sierra Nevada featuring Long Valley Caldera and the iconic Bishop Tuff. Some of the field trips focus on volcanic eruptive and emplacement processes, calling attention to the fact that the western United States provides opportunities to examine a wide range of volcanological phenomena at many scales.

The 2017 Scientific Assembly of the International Association of Volcanology and Chemistry of the Earth's Interior (IAVCEI) in Portland, Oregon, marks the first time that the U.S. volcanological community has hosted this quadrennial meeting since 1989, when it was held in Santa Fe, New Mexico. The 1989 field-trip guides are still widely used by students and professionals alike. This new set of field guides is similarly a legacy collection that summarizes decades of advances in our understanding of magmatic and tectonic processes of volcanic western North America.

The field of volcanology has flourished since the 1989 IAVCEI meeting, and it has profited from detailed field investigations coupled with emerging new analytical methods. Mapping has been enhanced by plentiful major- and trace-element whole-rock and mineral data, technical advances in radiometric dating and collection of isotopic data, GPS (Global Positioning System) advances, and the availability of lidar (light detection and ranging) imagery. Spectacularly effective microbeam instruments, geodetic and geophysical data collection and processing, paleomagnetic determinations, and modeling capabilities have combined with mapping to provide new information and insights over the past 30 years. The collective works of the international community have made it possible to prepare wholly new guides to areas across the western United States. These comprehensive field guides are available, in large part, because of enormous contributions from many experienced geologists who have devoted entire careers to their field areas. Early career scientists are carrying forward and refining their foundational work with impressive results.

Our hope is that future generations of scientists as well as the general public will use these field guides as introductions to these fascinating areas and will be enticed toward further exploration and field-based research.

Michael Dungan, University of Oregon Judy Fierstein, U.S. Geological Survey Cynthia Gardner, U.S. Geological Survey Dennis Geist, National Science Foundation

Anita Grunder, Oregon State University John Wolff, Washington State University

Field-trip committee, IAVCEI 2017 


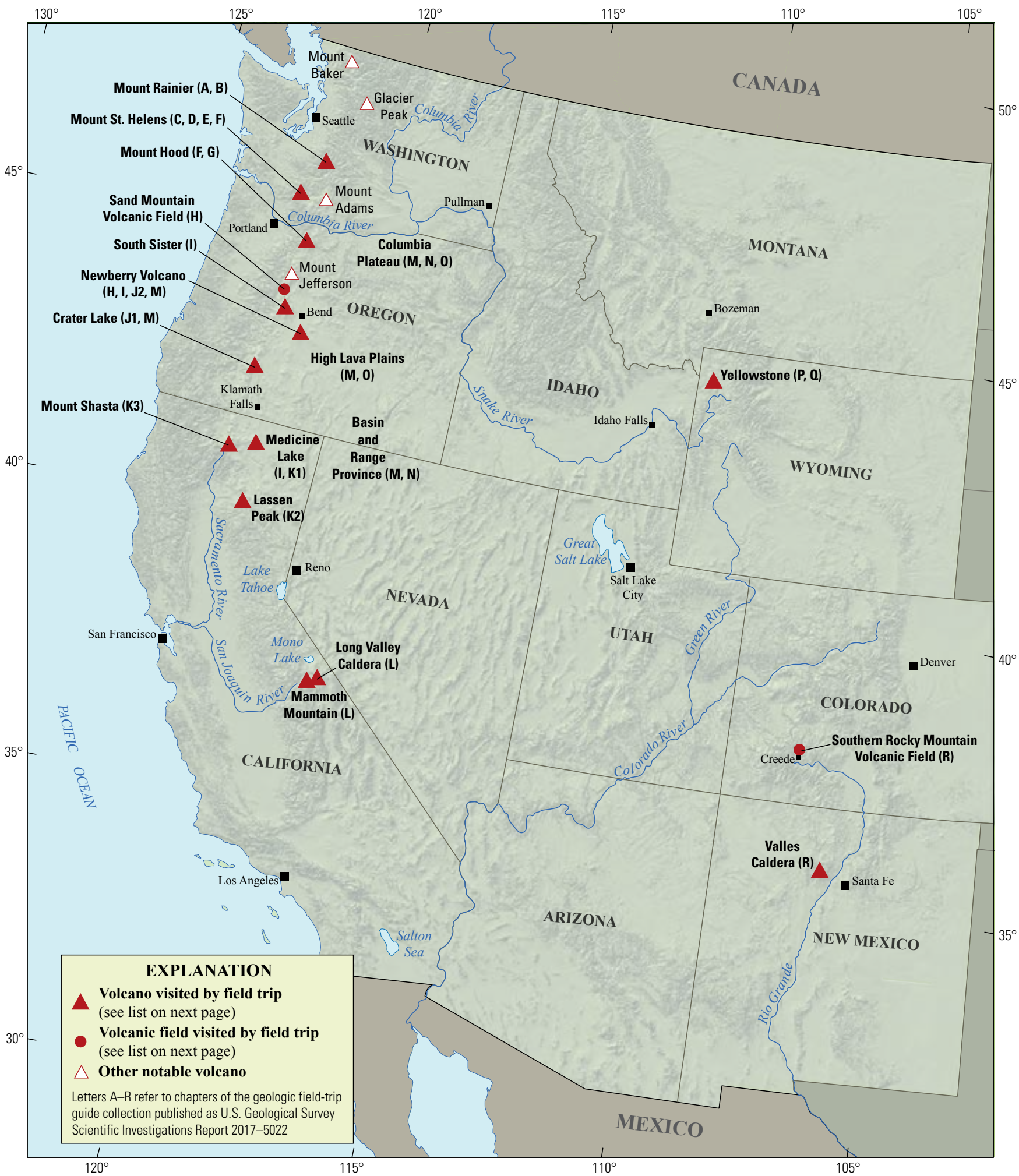

Map of the western United States showing volcanoes and volcanic fields visited by geologic field trips scheduled in conjunction with the 2017 meeting of the International Association of Volcanology and Chemistry of the Earth's Interior (IAVCEI) in Portland, Oregon, and available as chapters in U.S. Geological Survey Scientific Investigations Report 2017-5022. Shaded-relief base from U.S. Geological Survey National Elevation Dataset 30-meter digital elevation model data.

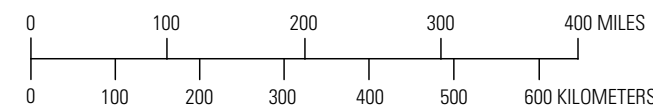




\section{Chapter \\ letter \\ Title}

A

B

C

D

E

$\mathrm{F}$

G

H

I

J

J1

J2

K

K1

K2

K3

$\mathrm{L}$

M

$\mathrm{N}$

0

P

0

R
Field-Trip Guide to Volcanism and Its Interaction with Snow and Ice at Mount Rainier, Washington

Field-Trip Guide to Subaqueous Volcaniclastic Facies in the Ancestral Cascades Arc in Southern Washington State-The Ohanapecosh Formation and Wildcat Creek Beds

Field-Trip Guide for Exploring Pyroclastic Density Current Deposits from the May 18, 1980, Eruption of Mount St. Helens, Washington

Field-Trip Guide to Mount St. Helens, Washington-An overview of the Eruptive History and Petrology, Tephra Deposits, 1980 Pyroclastic Density Current Deposits, and the Crater

Field-Trip Guide to Mount St. Helens, Washington—Recent and Ancient Volcaniclastic Processes and Deposits

Geologic Field-Trip Guide of Volcaniclastic Sediments from Snow- and IceCapped Volcanoes-Mount St. Helens, Washington, and Mount Hood, Oregon

Field-Trip Guide to Mount Hood, Oregon, Highlighting Eruptive History and Hazards

Field-Trip Guide to Mafic Volcanism of the Cascade Range in Central Oregon-A Volcanic, Tectonic, Hydrologic, and Geomorphic Journey

Field-Trip Guide to Holocene Silicic Lava Flows and Domes at Newberry Volcano, Oregon, South Sister Volcano, Oregon, and Medicine Lake Volcano, California

Overview for Geologic Field-Trip Guides to Mount Mazama, Crater Lake Caldera, and Newberry Volcano, Oregon

Geologic Field-Trip Guide to Mount Mazama and Crater Lake Caldera, Oregon

Field-Trip Guide to the Geologic Highlights of Newberry Volcano, Oregon

Overview for Geologic Field-Trip Guides to Volcanoes of the Cascades Arc in Northern California

Geologic Field-Trip Guide to Medicine Lake Volcano, Northern California, Including Lava Beds National Monument

Geologic Field-Trip Guide to the Lassen Segment of the Cascades Arc, Northern California

Geologic Field-Trip Guide to Mount Shasta Volcano, Northern California

Geologic Field-Trip Guide to Long Valley Caldera, California

Field-Trip Guide to a Volcanic Transect of the Pacific Northwest

Field-Trip Guide to the Vents, Dikes, Stratigraphy, and Structure of the Columbia

River Basalt Group, Eastern Oregon and Southeastern Washington

Field-Trip Guide to Flood Basalts, Associated Rhyolites, and Diverse Post-Plume Volcanism in Eastern Oregon

Geologic Field-Trip Guide to the Volcanic and Hydrothermal Landscape of Yellowstone Plateau, Montana and Wyoming

Field-Trip Guide to the Petrology of Quaternary Volcanism on the Yellowstone Plateau, Idaho and Wyoming

Field-Trip Guide to Continental Arc to Rift Volcanism of the Southern Rocky Mountains-Southern Rocky Mountain, Taos Plateau, and Jemez Volcanic Fields of Southern Colorado and Northern New Mexico 


\section{Contributing Authors}

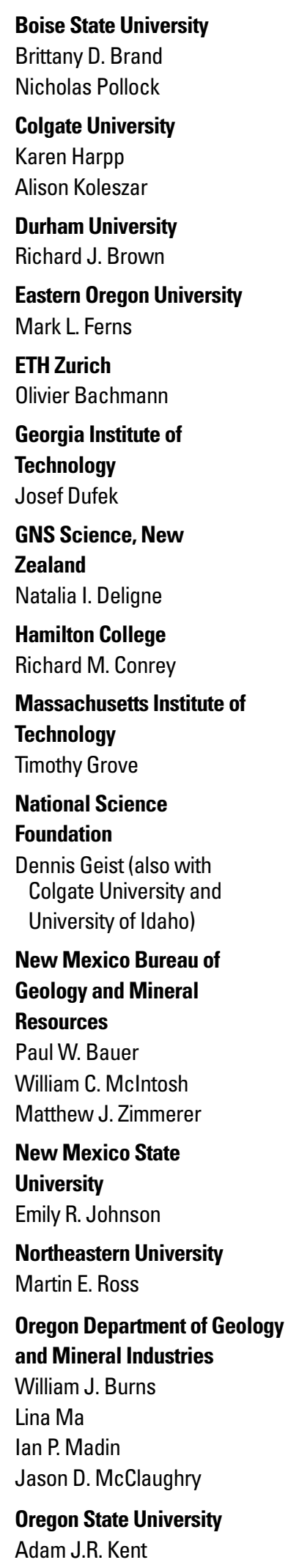

\author{
Portland State University \\ Jonathan H. Fink (also with \\ University of British Columbia) \\ Martin J. Streck \\ Ashley R. Streig
}

San Diego State University
Victor E. Camp
Smithsonian Institution
Lee Siebert
Universidad Nacional
Autónoma de San Luis Potosi
Damiano Sarocchi
University of California, Davis
Kari M. Cooper

University of Liverpool
Peter B. Kokelaar
University of Northern Colorado
Steven W. Anderson
University of Oregon
Ilya N. Binderman
Michael A. Dungan
Daniele Mckay (also with
Oregon State University and
Oregon State University,
Cascades)
University of Portland
Kristin Sweeney
University of Tasmania
Martin Jutzeler
Jocelyn McPhie
University of Utah
Jamie Farrell

U.S. Army Corps of

Engineers

Keith I. Kelson

U.S. Forest Service

Gordon E. Grant (also with Oregon State University)

\section{U.S. Geological Survey}

Charles R. Bacon

Andrew T. Calvert

Christine F. Chan

Robert L. Christiansen

Michael A. Clynne

Michael A. Cosca

Julie M. Donnelly-Nolan
Benjamin J. Drenth

William C. Evans

Judy Fierstein

Cynthia A. Gardner

V.J.S. Grauch

Christopher J. Harpel

Wes Hildreth

Richard P. Hoblitt

Peter W. Lipman

Jacob B. Lowenstern

Jon J. Major

Seth C. Moran

Lisa A. Morgan

Leah E. Morgan

L.J. Patrick Muffler

Jim O'Connor

John S. Pallister

Thomas C. Pierson

Joel E. Robinson

Juliet Ryan-Davis

Kevin M. Scott

William E. Scott

Wayne (Pat) Shanks

David R. Sherrod

Thomas W. Sisson

Mark Evan Stelten

Weston Thelen

Ren A. Thompson

Kenzie J. Turner

James W. Vallance

Alexa R. Van Eaton

Jorge A. Vazquez

Richard B. Waitt

Heather M. Wright

U.S. Nuclear Regulatory

Commission

Stephen Self (also with University of California, Berkeley)

Washington State University

Joseph R. Boro

Owen K. Neill

Stephen P. Reidel

John A. Wolff

Acknowledgments

Juliet Ryan-Davis and Kate Sullivan created the overview map, and Vivian Nguyen created the cover design for this collection of field-trip guide books. The field trip committee is grateful for their contributions. 


\section{Contents}

Preface

Contributing Authors .................................................................................................................

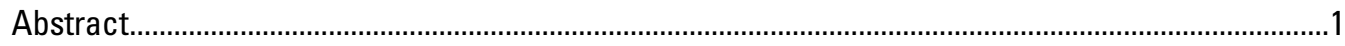

The Yellowstone Hot Spot and Snake River Plain ..........................................................................

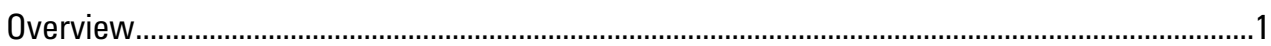

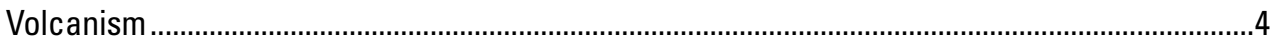

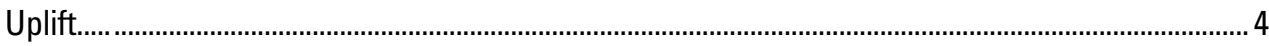

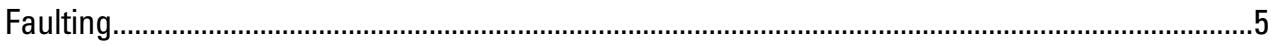

The Yellowstone Magmatic and Hydrothermal System ....................................................................

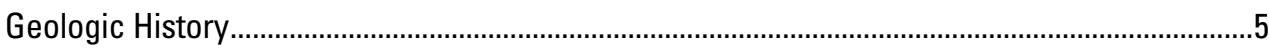

Eruptive History of Yellowstone Plateau Volcanic Field (YPVF) ............................................

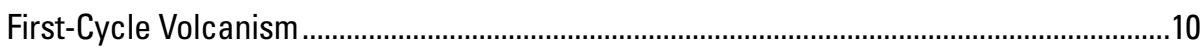

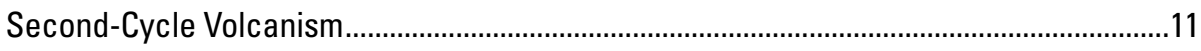

Third-Cycle Volcanism ....................................................................................................

Precaldera Volcanism.........................................................................................11

Cataclysmic Caldera-Forming Volcanism ................................................................11

Postcaldera Volcanism (Plateau Rhyolite) ..................................................................13

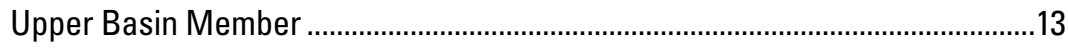

Mallard Lake Member ...............................................................................15

Central Plateau Member .....................................................................................15

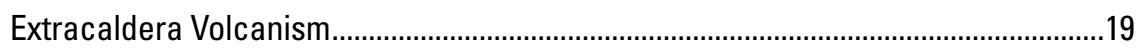

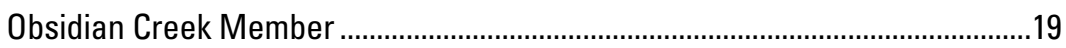

Roaring Mountain Member ……………………………….................................19

Present-Day Magmatic System and Crustal Structure …………..............................................19

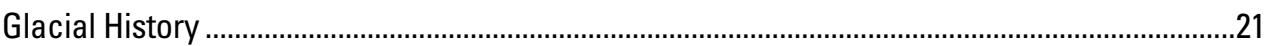

Thermal Areas and Hydrothermal Activity ..............................................................................22

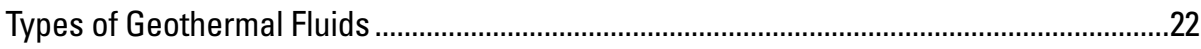

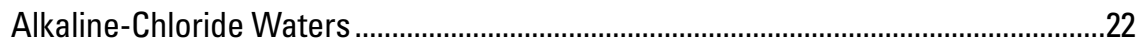

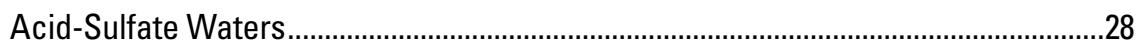

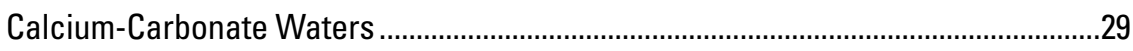

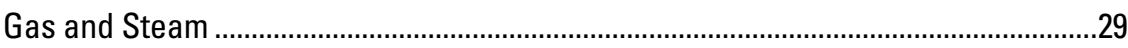

Connection Between Geography and Thermal Area Type ...............................................29

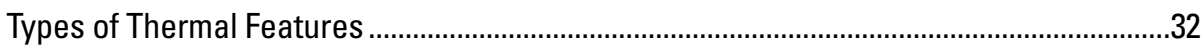

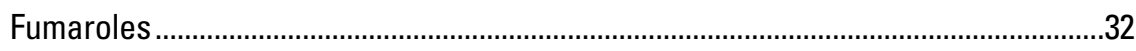

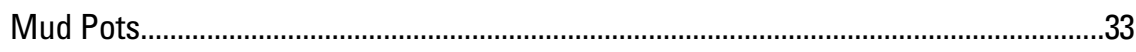

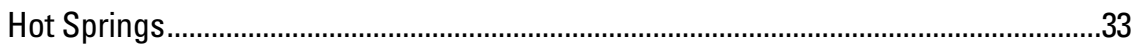

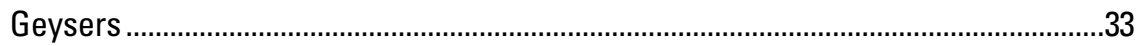

Hydrothermal Explosions ..............................................................................................

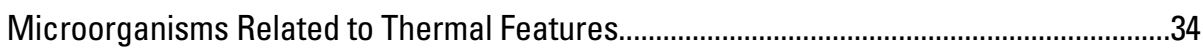

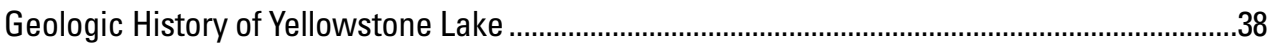

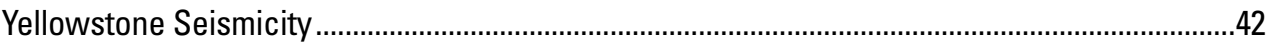

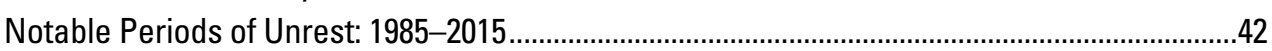

Yellowstone National Park and the Yellowstone Volcano Observatory................................................45 


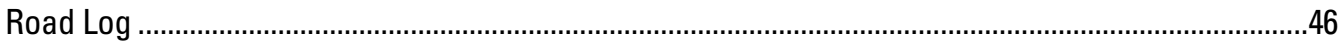

Day 1: Meet at Bozeman in the Late Afternoon.......................................................................46

Day 2: Bozeman to Old Faithful via West Yellowstone, Montana...................................................46

Stop 1a. Hebgen Lake Fault Scarp.......................................................................................

Stop 1b. Earthquake Lake Visitor Center ..............................................................................4

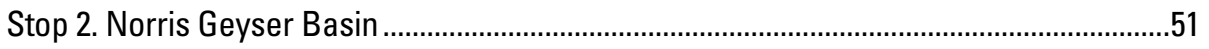

Stop 3. Tuff Cliff ..........................................................................................................

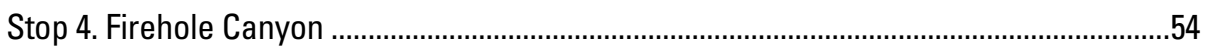

Stop 5. Midway Geyser Basin..........................................................................................56

Day 3: Old Faithful to Pitchstone Plateau and West Thumb Geyser Basin with Return to Old

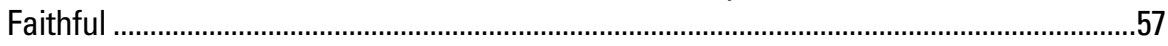

Stop 6. Phantom Fumarole Trailhead and Pitchstone Plateau Flow ..................................60

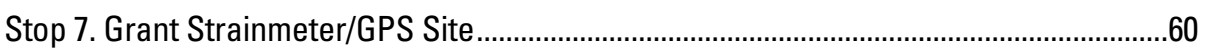

Stop 8. West Thumb Overlook Trail...................................................................................62

Stop 9. West Thumb Geyser Basin ...................................................................................62

Stop 10. Upper Geyser Basin, Including Old Faithful and Geyser Hill.................................62

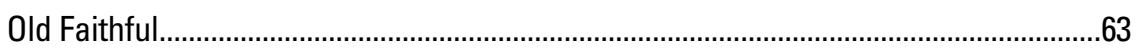

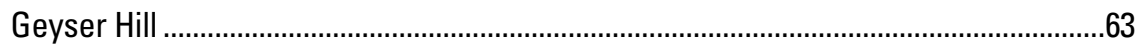

Day 4: Old Faithful to Mary Bay and Elephant Back Mountain, with Return to Lake Village .....63

Stop 11. Indian Pond, Storm Point, and Mary Bay.............................................................67

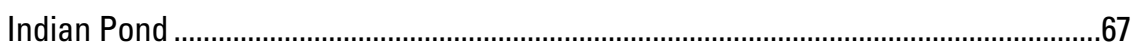

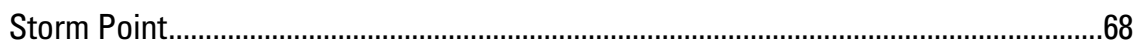

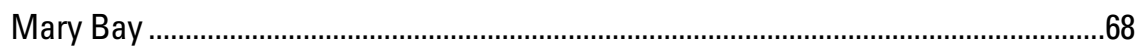

Stop 12. Elephant Back Mountain................................................................................70

Day 5: Lake Village to Mud Volcano, Grand Canyon of the Yellowstone, Crater Hills, and Return to Lake Village .....................................................................................................71

Stop 13. Mud Volcano..................................................................................................72

Stop 14. Grand Canyon of the Yellowstone ………………............................................73

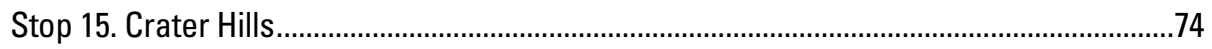

Day 6: Lake Village to Caldera Overlook on Flanks of Mount Washburn, Calcite Springs

Overlook, Lava Creek Tuff at Lost Creek, and Mammoth Hot Springs Terraces

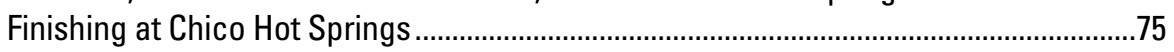

Stop 16. Caldera Overlook at Mount Washburn................................................................. 77

Stop 17. Calcite Springs Overlook ..................................................................................

Stop 18. Lava Creek Tuff at Lost Creek.................................................................................77

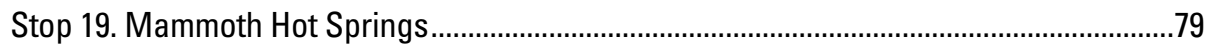

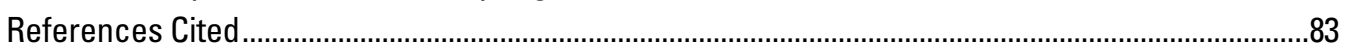

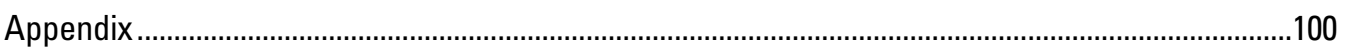




\section{Figures}

1. Area map showing all field trip stops on a topographic shaded-relief map overlain by geology

2. Map showing the track of the Yellowstone hot spot over the past 17 million years from the McDermitt Volcanic Field to the Yellowstone Plateau Volcanic Field

3. Schematic cross section of Yellowstone Caldera showing the bimodal magmatic system with basaltic magma underlying the silicic magma reservoir

4. Map panels showing the distribution of major caldera-forming ignimbrite deposits from the three major caldera-forming eruption cycles of the Yellowstone Plateau Volcanic Field

5. Stratigraphic correlation diagram and generalized cross section of third-cycle volcanic rocks of the Yellowstone Plateau Volcanic Field (YPVF)

6. Maps displaying the stages of evolution of the third-cycle Yellowstone Caldera associated with the eruption of the Lava Creek Tuff of Yellowstone Group

7. Plots of oxygen isotope systematics and ages of Yellowstone rhyolites including glass and minerals from postcaldera rhyolites.

8. Plot of dissolved volatile contents of quartz-hosted glass inclusions of pre-eruptive magmas as determined through analysis of silicate melt inclusions trapped in phenocrysts from Yellowstone lavas and tuffs.

9. Cross section of the Yellowstone magma reservoir by means of seismic tomography

10. Diagram illustrating the orographic effect of the Yellowstone Plateau (YP) and the Yellowstone crescent of high terrain (YCHT) on precipitation in the region of the Snake River Plain and Yellowstone Plateau.

11. Summary map of recessional moraine ages of the northern Yellowstone glacier from cosmogenic ${ }^{10} \mathrm{Be}$ dating of glacial boulders

12. Map showing the location of active thermal areas categorized by hydrothermal fluid type and the location of large hydrothermal explosion craters with associated breccia deposits in Yellowstone National Park

13. Piper diagram showing chemical variations in Yellowstone hydrothermal fluids

14. Diagram illustrating the relationship between $\mathrm{pH}$ and dissolved sulfate in Yellowstone hydrothermal fluids.

15. Generalized schematic diagram of mixing, boiling, degassing, and geochemical reaction processes in the subsurface of the Upper Geyser Basin affecting hydrothermal fluids

16. Map showing helium isotope ratios from hot springs and fumaroles in Yellowstone National Park

17. Diagram showing the factors relating to hydrothermal fluid flow beneath lava flows ....................... 31

18. Photographs showing the wide range of gas discharge from thermal pools at Yellowstone .........32

19. Diagram showing the evolution and processes associated with hydrothermal explosions.............35

20. Bar graphs showing the maximum size of hydrothermal explosion craters and thermal basins

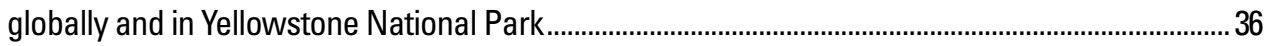

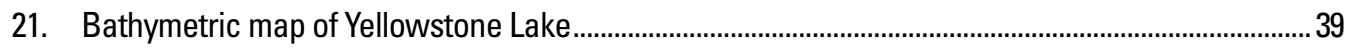

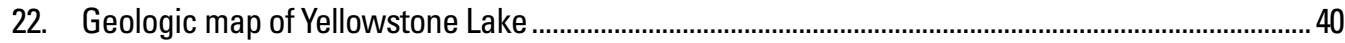

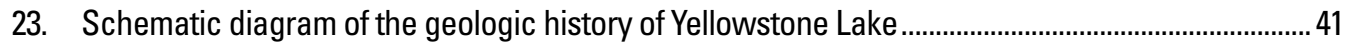

24. Map showing earthquakes at Yellowstone National Park and the surrounding area recorded by the Yellowstone Seismic Network from 1972 to the present.

25. Interferometric synthetic aperture radar (InSAR) image of Yellowstone National Park showing the range change of ground surface to satellite for the period from September 2004 to August 2006 
26. Overview graph of seismicity and ground deformation in the Yellowstone Caldera.......................... 45

27. Map of the Yellowstone Seismic Network as of 2016 ................................................................... 47

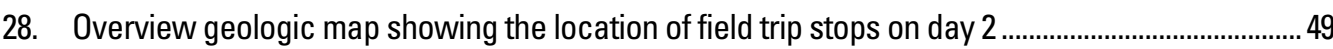

29. Photographs of the Hebgen Lake fault scarp and Madison rockslide (Stops 1a and 1b) .................50

30. Photograph of the main phase of an eruption of Steamboat Geyser in the Norris Geyser Basin on May 23, 2005 (Stop 2)

31. Photographs at Stop 2 demonstrating normal conditions at the alkaline-chloride Cistern Spring versus the drained pool immediately after an eruption of nearby Steamboat Geyser ...................... 52

32. Aerial view of Porkchop Geyser, located in the Norris Geyser Basin (Stop 2) ................................. 53

33. Photograph at Tuff Cliff (Stop 3) showing characteristic zones within the Lava Creek Tuff of

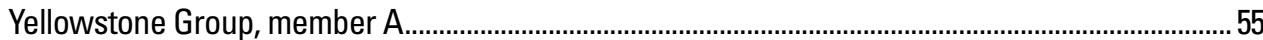

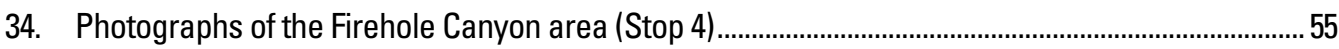

35. Oblique overhead image of Grand Prismatic Spring and Excelsior Geyser in the Midway

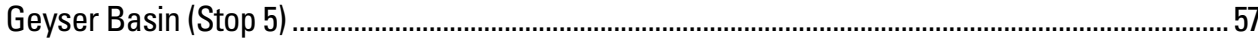

36. Geologic map and field trip stops on day 3 ................................................................................... 58

37. View on day 3 looking east from Grand Loop Road immediately west of Duck Lake.........................59

38. Map, seismograph, and spectrogram showing evidence for a seiche event on Yellowstone

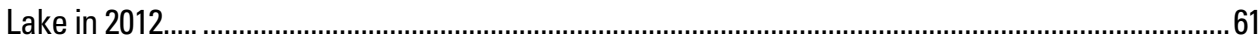

39. Geologic map of the Upper Geyser Basin area (Stop 10) ...............................................................64

40. Generalized map and cross section showing hydrothermal acoustic tremor data near Old

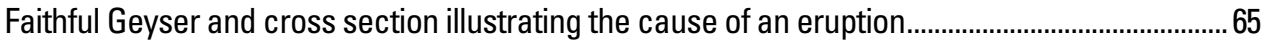

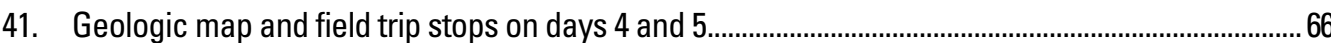

42. Photograph looking southwest toward Indian Pond, Storm Point, and Mary Bay (Stop 11)............67

43. Yellowstone Lake earthquake swarm from 2008 to 2009.................................................................. 69

44. Photograph of hydrothermal explosion deposits along the north shore of Yellowstone Lake

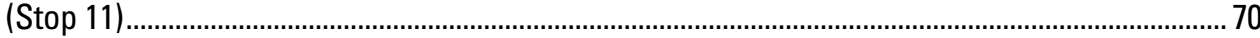

45. Photograph and lidar image at Elephant Back Mountain (Stop 12) ................................................ 71

46. Photographs of hydrothermally altered rocks below Lower Falls in Grand Canyon of the Yellowstone (Stop 14) ......................................................................................................................... 73

47. Photographs of the Crater Hills thermal area (Stop 15) ……............................................................ 75

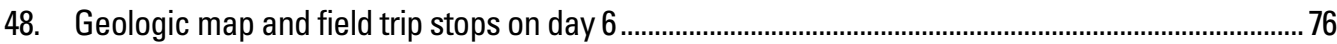

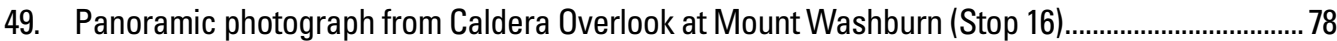

50. View looking northwest from Calcite Springs Overlook (Stop 17) ...................................................... 78

51. Photographs of an exposure of Lava Creek Tuff of Yellowstone Group at Lost Creek (Stop 18) ..... 79

52. Geologic map on of the Mammoth Hot Springs area in Yellowstone National Park (Stop 19) ........ 80

53. Photograph and facies diagram at Mammoth Hot Springs (Stop 19) ................................................. 82

\section{Tables}

1. Ages of key Yellowstone volcanic units.............................................................................................

2. Chemistry, age, and mineralogy of Yellowstone volcanic rocks .......................................................... 16

3. Major element composition, $\mathrm{pH}$, temperature, and hydrothermal fluid type of selected Yellowstone hot springs.

4. Representative microorganisms in Yellowstone National Park .............................................................. 


\section{Conversion Factors}

[International System of Units to U.S. customary units]

\begin{tabular}{|c|c|c|}
\hline Multiply & By & To obtain \\
\hline \multicolumn{3}{|c|}{ Length } \\
\hline centimeter $(\mathrm{cm})$ & 0.3937 & inch (in.) \\
\hline millimeter $(\mathrm{mm})$ & 0.03937 & inch (in.) \\
\hline meter (m) & 3.281 & foot $(\mathrm{ft})$ \\
\hline kilometer (km) & 0.6214 & mile (mi) \\
\hline \multicolumn{3}{|c|}{ Area } \\
\hline square kilometer $\left(\mathrm{km}^{2}\right)$ & 247.1 & acre \\
\hline square kilometer $\left(\mathrm{km}^{2}\right)$ & 0.3861 & square mile $\left(\mathrm{mi}^{2}\right)$ \\
\hline \multicolumn{3}{|c|}{ Volume } \\
\hline liter $(\mathrm{L})$ & 0.2642 & gallon (gal) \\
\hline cubic kilometer $\left(\mathrm{km}^{3}\right)$ & 0.2399 & cubic mile $\left(\mathrm{mi}^{3}\right)$ \\
\hline \multicolumn{3}{|c|}{ Flow rate } \\
\hline liter per second $(\mathrm{L} / \mathrm{s})$ & 15.85 & gallon per minute (gal/min) \\
\hline meter per day (m/d) & 3.281 & foot per day (ft/d) \\
\hline meter per year $(\mathrm{m} / \mathrm{yr})$ & 3.281 & foot per year (ft/yr) \\
\hline cubic meter per day $\left(\mathrm{m}^{3} / \mathrm{d}\right)$ & 264.2 & gallon per day (gal/d) \\
\hline millimeter per year (mm/yr) & 0.03937 & inch per year (in/yr) \\
\hline kilometer per hour $(\mathrm{km} / \mathrm{h})$ & 0.6214 & mile per hour $(\mathrm{mi} / \mathrm{h})$ \\
\hline \multicolumn{3}{|c|}{ Mass } \\
\hline $\operatorname{gram}(\mathrm{g})$ & 0.03527 & ounce, avoirdupois (oz) \\
\hline kilogram (kg) & 2.205 & pound, avoirdupois (lb) \\
\hline metric ton per day & 1.102 & ton per day (ton/d) \\
\hline metric ton per year & 1.102 & ton per year (ton/yr) \\
\hline \multicolumn{3}{|c|}{ Pressure } \\
\hline kilopascal $(\mathrm{kPa})$ & 0.009869 & atmosphere, standard (atm) \\
\hline kilopascal $(\mathrm{kPa})$ & 0.01 & bar \\
\hline
\end{tabular}

Temperature in degrees Celsius $\left({ }^{\circ} \mathrm{C}\right)$ may be converted to degrees Fahrenheit $\left({ }^{\circ} \mathrm{F}\right)$ as ${ }^{\circ} \mathrm{F}=(1.8 \times$ $\left.{ }^{\circ} \mathrm{C}\right)+32$. 


\section{Abbreviations}

\begin{tabular}{|c|c|c|c|}
\hline An & anorthite & $M_{L}$ & local magnitude \\
\hline$A P G$ & absolute pressure gauge & $\mathrm{M}_{\mathrm{w}}$ & moment magnitude \\
\hline $\mathrm{C}_{2} \mathrm{H}_{6}$ & ethane & MLD & Mallard Lake Dome \\
\hline $\mathrm{CaCO}_{3}$ & calcium carbonate & NSF & National Science Foundation \\
\hline $\mathrm{CH}_{4}$ & methane & $\mathrm{N}_{2}$ & molecular nitrogen \\
\hline $\mathrm{Cl}^{-}$ & chloride ion & ${ }^{18} 0$ & oxygen-18 isotope \\
\hline $\mathrm{CO}$ & carbon monoxide & $\mathrm{O}_{2}$ & molecular oxygen \\
\hline $\mathrm{CO}_{2}$ & carbon dioxide & Or & orthoclase \\
\hline $\mathrm{CO}_{3}$ & carbonate & PBO & Plate Boundary Observatory \\
\hline$\delta \mathrm{D}$ & ratio of isotope ${ }^{2} \mathrm{H}$ to ${ }^{1} \mathrm{H}$ compared to that of a standard & $\mathrm{pH}$ & negative $\log _{10}$ of hydrogen ion concentration \\
\hline DNA & deoxyribonucleic acid & ppm & parts per million \\
\hline$\delta^{18} 0$ & ratio of isotope ${ }^{18} 0$ to ${ }^{16} 0$ compared to that of a standard & $\mathrm{R}$ & ${ }^{3} \mathrm{He} /{ }^{4} \mathrm{He}$ ratio of a sample \\
\hline $\mathrm{F}-$ & fluoride & $\mathrm{Ra}$ & ${ }^{3} \mathrm{He} /{ }^{4} \mathrm{He}$ ratio of Earth's atmosphere \\
\hline $\mathrm{FeS}_{2}$ & pyrite & $\mathrm{S}^{\circ}$ & elemental sulfur \\
\hline GPS & global positioning system & SCD & Sour Creek Dome \\
\hline $\mathrm{H}_{2}$ & molecular hydrogen & $\mathrm{SiO}_{2}$ & silica \\
\hline $\mathrm{HCO}_{3}$ & bicarbonate & SMOW & standard mean ocean water \\
\hline HD-YLAKE & Hydrothermal Dynamics of Yellowstone Lake project & $\mathrm{SO}_{4}$ & sulfate \\
\hline HREE & heavy rare earth elements & SRP & Snake River Plain \\
\hline HS & bisulfide & USGS & U.S. Geological Survey \\
\hline $\mathrm{H}_{2} \mathrm{~S}$ & hydrogen sulfide & UU & University of Utah \\
\hline InSAR & Interferometric Synthetic Aperture Radar & UNAVCO & University NAVSTAR Consortium \\
\hline IRIS & Incorporated Research Institutions for Seismology & Vp & P-wave velocity \\
\hline ka & kilo-annum (thousand years before present) & wt. & weight \\
\hline lidar & light detection and ranging & YCHT & Yellowstone crescent of high terrain \\
\hline LOI & loss on ignition & YP & Yellowstone Plateau \\
\hline Ma & mega-annum (million years before present) & YPVF & Yellowstone Plateau Volcanic Field \\
\hline $\mathrm{M}_{\mathrm{C}}$ & coda magnitude & YVO & Yellowstone Volcano Observatory \\
\hline $\mathrm{M}_{\text {COMP }}$ & magnitude of completeness & $\%$ & per mil (parts per thousand) \\
\hline
\end{tabular}




\title{
Geologic Field-Trip Guide to the Volcanic and Hydrothermal Landscape of the Yellowstone Plateau
}

\author{
By Lisa A. Morgan' ${ }^{1}$ W.C. Pat Shanks' ${ }^{1}$, Jacob B. Lowenstern'1, Jamie M. Farrell'², and Joel E. Robinson'
}

\section{Abstract}

Welcome to Yellowstone National Park, a nearly $9,000 \mathrm{~km}^{2}$ $\left(\sim 3,468 \mathrm{mi}^{2}\right)$ area preserved in 1872 as the world's first national park for its unique, extraordinary, and magnificent natural features. Rimmed by a crescent of older mountainous terrain, Yellowstone National Park has at its core the Quaternary Yellowstone Plateau, an undulating landscape shaped by forces of late Cenozoic explosive and effusive volcanism, on-going tectonism, glaciation, and hydrothermal activity. The Yellowstone Caldera is the centerpiece of the Yellowstone Plateau.

The Yellowstone Plateau lies at the most northeastern front of the 17-Ma Yellowstone hot spot track, one of the few places on Earth where time-transgressive processes on continental crust can be observed in the volcanic and tectonic (faulting and uplift) record at the rate and direction predicted by plate motion.

The 2.2-Ma-to-present Yellowstone Plateau Volcanic Field (YPVF) contains three large nested calderas. The Yellowstone Caldera erupted $>1,000 \mathrm{~km}^{3}$ of pyroclastic material and is the last major caldera-forming event, occurring at $0.63 \mathrm{Ma}$. The YPVF now is host to the world's largest concentration of hydrothermal features $(>10,000$ hot springs, geysers, hydrothermal explosion craters, mud pots, and fumaroles). Prior to the cataclysmic eruption of its caldera-forming Lava Creek Tuff of the Yellowstone Group, emplacement of both rhyolitic and basaltic lava flows occurred around what is now recognized as the topographic and structural margin of the caldera. Two significant periods of postcaldera volcanism have contributed to filling in the collapsed caldera; volcanism last occurred on the Yellowstone Plateau around 70,000 years ago. Hydrothermal activity is assumed to have been present prior to and immediately after major caldera events. Today, hydrothermal activity is concentrated within the Yellowstone Caldera and along zones of tectonic weakness. Travertine deposits at Mammoth Hot Springs date at least as far back as 375,000 years.

Over six days, this field trip presents an intensive overview into volcanism, tectonism, and hydrothermal activity on the Yellowstone Plateau (fig. 1). Field stops are linked directly to conceptual models related to monitoring of the various volcanic, geochemical, hydrothermal, and tectonic aspects of the greater Yellowstone system. Recent interest in young and possible future

${ }^{1}$ U.S. Geological Survey.

${ }^{2}$ University of Utah. volcanism at Yellowstone as well as new discoveries and synthesis of previous studies, (for example, tomographic, deformation, gas, aeromagnetic, bathymetric, and seismic surveys), provide a framework in which to discuss volcanic, hydrothermal, and seismic activity in this dynamic region.

\section{The Yellowstone Hot Spot and Snake River Plain}

\section{Overview}

The Yellowstone Plateau-Snake River Plain volcanic province (fig. 2) is considered one of the clearest examples of bimodal (basalt and rhyolite) volcanism on Earth. Until the 1970s, however, the Snake River Plain was considered primarily as a basaltic province due to the extensive cover of young basaltic lavas erupted as lava flows, shield volcanoes, fissure vents, rift systems, and cinder cones (King, 1982). While early workers in this area such as Mansfield and Ross (1935) recognized the extensive exposures of densely welded rhyolitic ignimbrite sheets, local rhyolitic lavas, domes, and fall deposits along the margins of the plain, few workers recognized that the basalts were genetically related to the rhyolites. On the Yellowstone Plateau, early explorers and scientists recognized that the volcanic terrain on the plateau was dominantly rhyolitic (Hague, 1896) with subordinate amounts of basalt. The link between volcanism (especially rhyolitic volcanism), faulting, and uplift on the Yellowstone Plateau with earlier volcanism (rhyolitic and basaltic), faulting, and uplift on the Snake River Plain, remained unrecognized for some time.

Armstrong and others (1975) showed that the initiation of rhyolitic and later basaltic volcanism along this track became systematically younger northeastward toward the Yellowstone Plateau. Morgan (1972) first postulated that the Yellowstone Plateau-Snake River Plain volcanic province represented a hot spot track analogous to that of Hawaii. A vigorous debate ensued as to whether or not this volcanic age progression results from a mantle plume beneath the southwest-moving North American plate. Arguments in favor of a mantle-plume origin can be found in Suppe and others (1975), Anders and others (1989), Pierce and Morgan (1992, 2002, 2009), Smith and Braile (1994), Yuan and Deuker (2005), Obrebski and others (2011), Tien and Zhou 


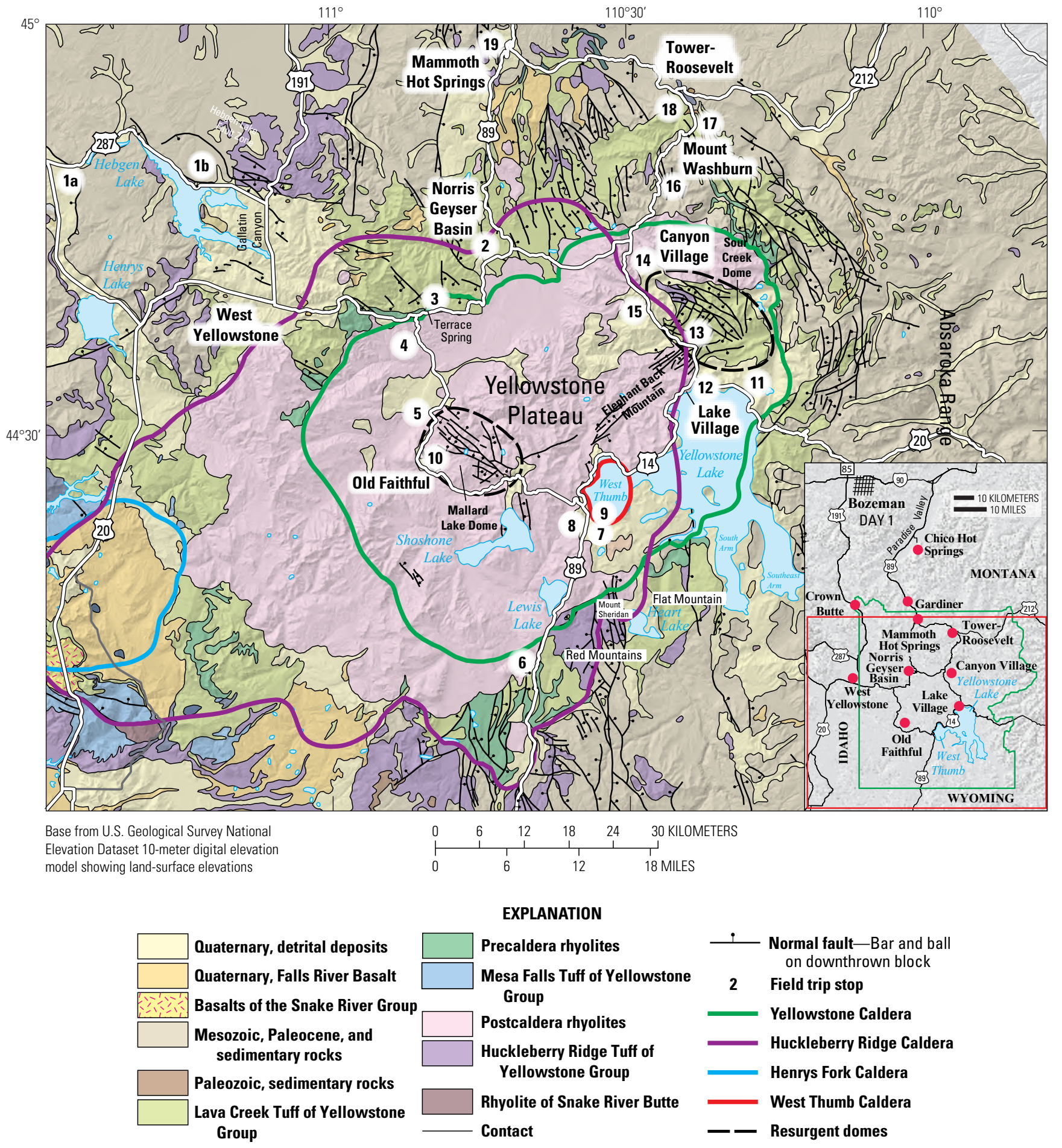

Figure 1. Area map showing all field trip stops on a topographic shaded-relief map overlain by geology from plate 3 of Christiansen (2001). The Yellowstone Caldera is outlined in green; resurgent domes are outlined with dashed black lines (Sour Creek Dome to northeast and Mallard Lake Dome to southwest); Henrys Fork Caldera is outlined in blue; Huckleberry Ridge Caldera is outlined in purple; West Thumb Caldera is outlined in red. Inset map is a gray-shaded topographic relief map of Yellowstone National Park and vicinity that highlights (red asterisks) places we will visit or pass on the field trip. On Day 1 of field trip, arrive and spend the night in Bozeman (see northwest corner of inset). Field trip stop numbers are provided on the map in black. The main road is shown by the heavy white line. Note that the first day in Bozeman has no field stops, and therefore is designated as just "Day 1" on the inset map. 


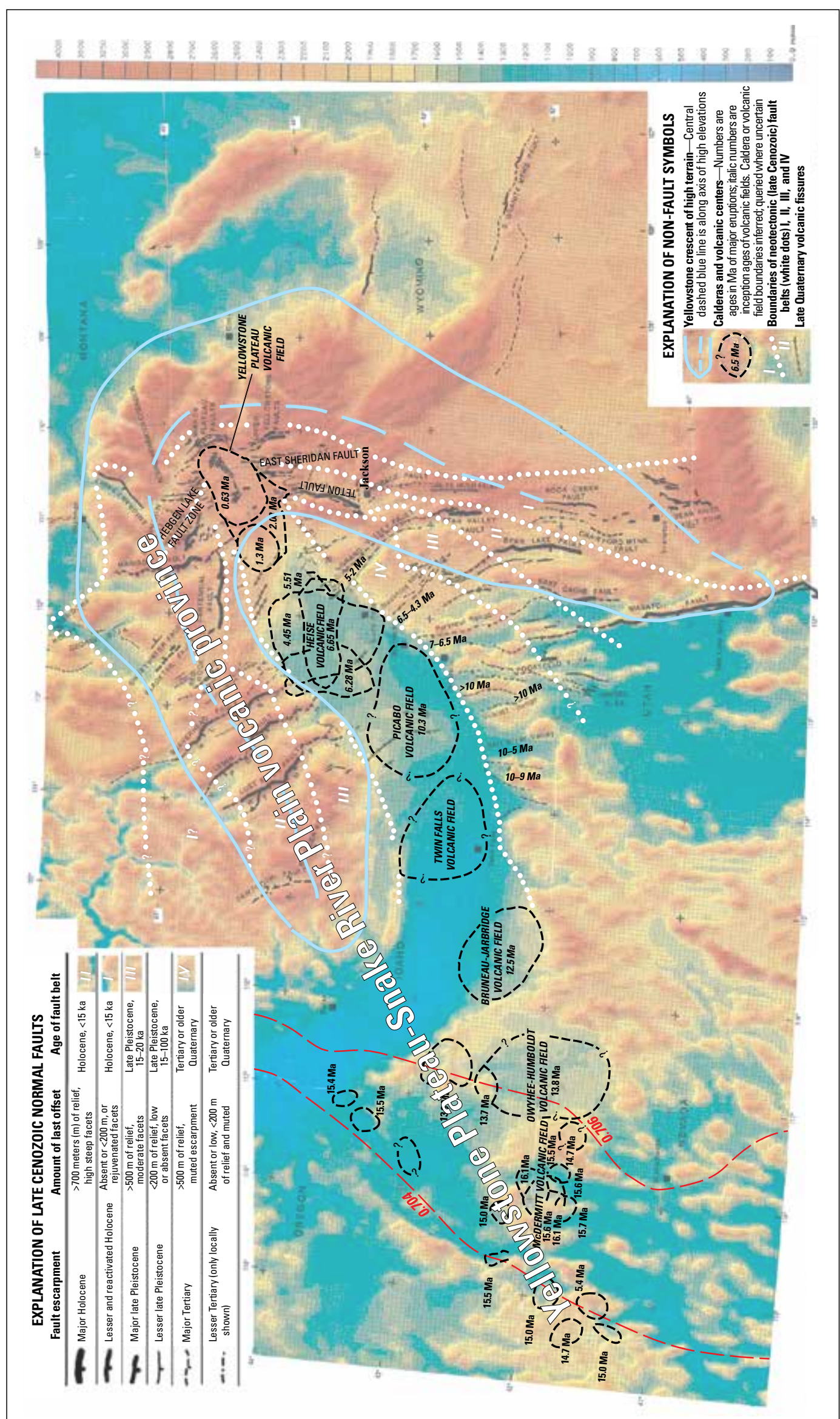

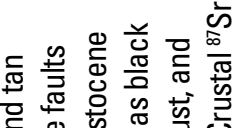

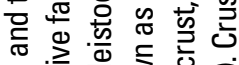

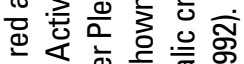

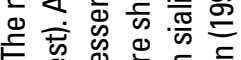

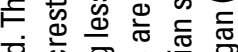

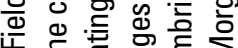

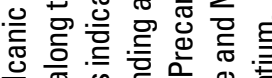

응 范

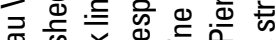

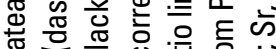

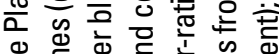

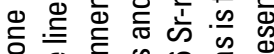

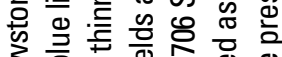

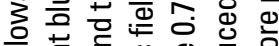

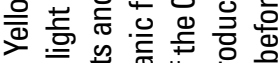

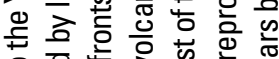

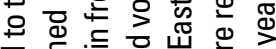

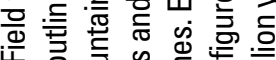

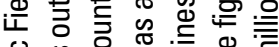

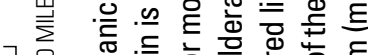

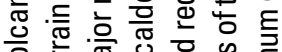

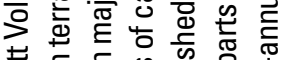

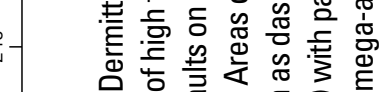

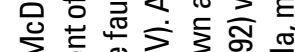

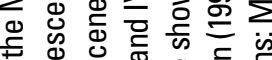

就苋芯芯芯.

은

s.

『

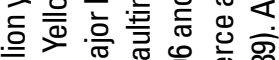

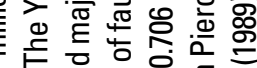

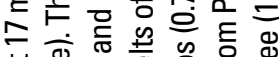

茄

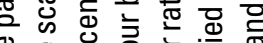

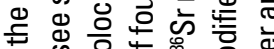

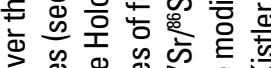

वे

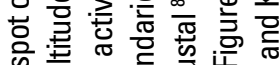

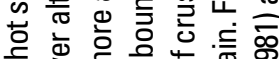

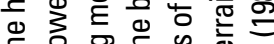

可

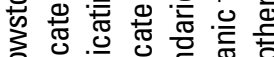

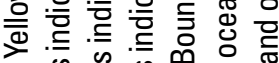

\& \& \&

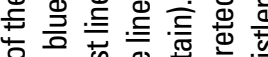

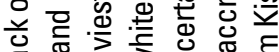

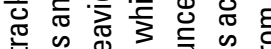

过 $\subseteq$ ब

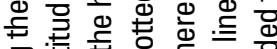

일 능

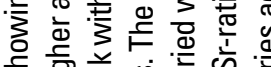

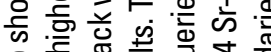

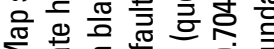

$\sum$ 否.

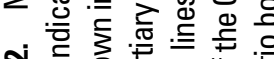

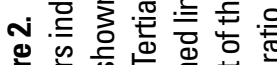

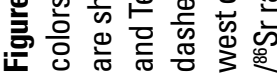


(2012), Camp and others (2015), and Coble and Mahood (2012, 2016). Arguments questioning a mantle origin can be found in Humphreys and others (2000), Christiansen and others (2002), Hamilton (2003), Leeman and others (2008, 2009), Manea and others (2009), McCurry and Rodgers (2009), James and others (2011), Fouch (2012), Kelbert and others (2012), and Foulger and others (2015).

Volcanism associated with the track of the Yellowstone hot spot began at approximately $17 \mathrm{Ma}$ with eruption of the Columbia River Plateau flood basalts and associated flood basalts in Oregon, Washington, and California and extensive rhyolite volcanism and mafic dikes in Nevada and Oregon over a north-south distance of $\sim 1,000 \mathrm{~km}$ (kilometers) (Pierce and Morgan, 1990, pl. 1; Pierce and Morgan, 1992, pl. 1; Pierce and Morgan, 2009, fig. 2; Camp and Ross, 2004; Coble and Mahood, 2012, 2016; Camp and others, 2015). According to the plume model, a large-diameter plume head at the base of a compositionally varied lithosphere can explain the aerial extent of the volcanism and intrusions. Basaltic magma and associated heat generated by decompression melting produced the Columbia River Plateau and related flood basalts. These were emplaced through thin Mesozoic oceanic crust, whereas the 17- to 14-Ma high-silica rhyolites of the Snake River Plain (compositionally distinct from more common rhyolites found in calc-alkalic suites) were generated above thicker, older, and more silicic crust (Draper, 1991; Pierce and Morgan, 1992, 2009; Camp and Ross, 2004; Nash and others, 2006; Savov and others, 2009; Coble and Mahood, 2012). The basalt versus rhyolite dichotomy can be attributed to contrasting crustal compositions that are delineated (fig. 2) by the ${ }^{87} \mathrm{Sr} /{ }^{86} \mathrm{Sr} 0.706$ and 0.704 contours (compare with Leeman and others (1992) and references therein).

East of the 0.706 contour is Precambrian sialic crust, whereas west of the 0.704 contour is Mesozoic accreted oceanic terrain (Kistler and others, 1981; Kistler and Lee, 1989). Paleozoic mafic crust is west of the 0.706 contour and east of the 0.704 contour.

The Yellowstone Plateau is the current focus of volcanic, hydrothermal, and tectonic activity.

\section{Volcanism}

Caldera-forming events on the Yellowstone Plateau-Snake River Plain volcanic province produced some of the largest rhyolitic eruptions known on Earth and range in volume from several hundred to greater than $2,500 \mathrm{~km}^{3}$ (cubic kilometers). Geologic mapping shows the regional extent and character of volcanism change from the initial widespread volcanism at $17 \mathrm{Ma}$ to a more focused area of volcanism around 13 to $10 \mathrm{Ma}$ and may represent a radical change in plume dimension and development (plume "head" to plume "tail") and changes in crustal composition (Pierce and Morgan, 1992, 2009; Pierce, Morgan, and Saltus, 2002). Around 10.3 Ma, the central Snake River Plain was host to two large and separated caldera-forming events (eruptions of the tuff of Big Bluff and the Arbon Valley Tuff) separated along the track by about $200 \mathrm{~km}$ and may represent a transitional phase (Morgan and others, 1997). Prior to $10 \mathrm{Ma}$, volcanism was not only widespread but also produced more frequent and higher temperature eruptions (see Bonnichsen and others, 2007). After $\sim 10 \mathrm{Ma}$, the aerial extent of volcanism narrowed to $<100 \mathrm{~km}$ wide and eruption temperatures of rhyolites decreased from $\sim 1,000^{\circ} \mathrm{C}$ (Honjo and others, 1992; Cathey and Nash, 2004, 2009; Bonnichsen and others, 2007) in the southwestern part of the province to a range of $\sim 800$ to $>900{ }^{\circ} \mathrm{C}$ on the Yellowstone Plateau (Hildreth and others, 1984; Loewen and Bindeman, 2015), and the frequency of eruptions decreased (Hughes and McCurry, 2002; Perkins and Nash, 2002). A large Bouguer gravity anomaly centered in southern Oregon has been interpreted to be associated mafic batholiths that fed the eruptions (Pierce and others, 2002).

The track is represented by a series of volcanic fields, each spanning a few million years and each characterized by multiple large, ignimbrite-producing, caldera-forming eruptions. A 2.3-million-year hiatus occurred between the last significant caldera-forming event (eruption of the 4.45-Ma Kilgore Tuff) in the adjacent and older Heise Volcanic Field to the southwest (Morgan and McIntosh, 2005) and the eruption of the 2.08-Ma Huckleberry Ridge Tuff of the Yellowstone Group in the younger Yellowstone Plateau Volcanic Field (YPVF) to the northeast (Wotzlaw and others, 2015). Within a particular volcanic field, no systematic age progression is apparent for the sequence of calderas (Pierce and Morgan, 1992; Morgan and McIntosh, 2005; Anders and others, 2014).

\section{Uplift}

Several observations are explained by hot spot uplift. The Yellowstone area stands high on the western North American plate and supports the Continental Divide. The Yellowstone crescent of high terrain (YCHT), outlined by the blue lines in figure 2, flares out in a "bow wave"-like pattern outward from the northeast progression of volcanism. It forms an arc that crests ahead (northeast) of the youngest volcanism. Some high mountain areas in this crescent near the east boundary of Yellowstone National Park are formed of weakly consolidated, erodible bedrock of the Eocene Absaroka Volcanic Supergroup. There, a gently rolling upland above tree line is sharply incised by steep, kilometer-deep valleys. Basaltic lava flows erupted onto this surface $3.6 \mathrm{Ma}$ and provide a timeline for uplift and the incision and formation of the canyons. This valley incision is best explained by young and ongoing uplift (Pierce and Morgan, 1992). Additional evidence for young uplift and incision can be seen along the southeast and northwest part of the YCHT near the borders of Yellowstone National Park, where high mountains are composed of readily erodible bedrock of Mesozoic shale and sandstone. Smith and Braile (1994) conclude that a 650-m topographic high centers on Yellowstone. Zircon provenance data are consistent with the notion that uplift was associated with migration of the Yellowstone hot spot, and that this controlled the locus of the eastward-migrating Continental Divide (Link and others, 2002; Beranek and others, 2006). 


\section{Faulting}

Zones of late Cenozoic faulting extend south and west from Yellowstone (fig. 2). Within these zones are four defined belts of distinctive fault timing and displacement (Pierce and Morgan, 1992). Belt I faults have postglacial $(<15 \mathrm{ka})$ offset but little accumulated total offset $(<200 \mathrm{~m})$; Belt II faults also have postglacial $(<15 \mathrm{ka})$ offset and $>700$ meters $(\mathrm{m})$ of range-front relief; Belt III faults have late Pleistocene (20-15 ka) offset and $>500 \mathrm{~m}$ range-front relief; and Belt IV faults have Tertiary or early Quaternary offset and $>500 \mathrm{~m}$ relief. These belts may be explained by activity arranged about the volcanic track in a "bow wave" fashion with the following progression: Belt I—initiation of Quaternary faulting; Belt II — culmination of activity; Belt III-waning activity; and Belt IV — cessation or great diminution of activity (on the south side of eastern Snake River Plain only). These belts of faulting are mainly on the crest and inner slope of the YCHT and may be gravity driven by the topographic gradient down the inner slope of this "bow-wave" form. Both the YCHT and the belts of faulting flare out more, by a factor of 1.6, on the south side of the track, possibly associated with a northwestward tilt of the plume. This flaring largely involves Belt IV faults that occur only on the south side of the plain.

The large-scale processes driving the Yellowstone hot spot are reflected in its surface geologic record, geophysical expression, and similarity to other hot spots. Tomographic images (Yuan and Dueker, 2005; Waite and others, 2006) reveal a plume-like feature extending from the Yellowstone Caldera to $\sim 500$ to $600 \mathrm{~km}$ depth and inclined 20 degrees northwest. This "plume" is an inclined, $100-\mathrm{km}$-wide, thermal anomaly with temperatures inferred as $180^{\circ} \mathrm{C}$ above ambient mantle temperatures. More recent tomographic surveys have extended the plume to depths in excess of 1,000 km (Obrebski and others, 2010; Tian and Zhao, 2012). The Yellowstone geoid anomaly, an 800-km-wide topographic swell centered on the Yellowstone Plateau, is the largest geoid anomaly in the conterminous United States (Lowry and others, 2000). This geoid-anomaly culmination on Yellowstone contrasts with both the U.S. Bouguer gravity and topography anomalies that culminate in western Colorado. Geoid anomalies reveal deep isostatic compensation.

\section{The Yellowstone Magmatic and Hydrothermal System}

\section{Geologic History}

Yellowstone National Park is known for its volcanic and hydrothermal features. The northern, eastern, and southern boundaries of the park, however, are covered by andesitic volcanic rocks of the Eocene Absaroka Volcanic Supergroup (Smedes and Prostka, 1972), scattered exposures of Paleozoic carbonate rocks, Precambrian granitic gneisses, and Paleocene and Mesozoic sedimentary deposits; all are heavily faulted. These strata and associated faults almost certainly underlie the Quaternary volcanic suite that forms the heart and major geologic units of the Yellowstone Plateau (Christiansen and Blank, 1972; Christiansen, 2001, plate 1).

\section{Eruptive History of Yellowstone Plateau Volcanic Field (YPVF)}

The active tectonic and volcanic features in Yellowstone are the result of large-scale processes that have been occurring along the Snake River Plain for the past 17 million years and now are focused under the Yellowstone Plateau. Presently, a massive and active bimodal rhyolitic-basaltic magmatic system underlies Yellowstone National Park, directly affecting current tectonic and hydrothermal activity (fig. 3). Over the past 2.2 million years, the YPVF has evolved in an area of about $17,000 \mathrm{~km}^{2}$ through three cycles of caldera-forming activity that overlap in space and time (fig. 4) (Christiansen, 2001, table 2; Lanphere and others, 2002). Three largevolume $\left(280-2,500 \mathrm{~km}^{3}\right)$, welded to densely welded, rhyolitic ignimbrite sheets, one corresponding to each cycle, constitute a regional time-stratigraphic framework of Quaternary volcanism that covered thousands of square kilometers and are formally included in the Yellowstone Group (Christiansen, 2001). Based on isopach maps and slight differences in mineralogy and trace-element chemistry, both the Huckleberry Ridge Tuff and the Lava Creek Tuff have multiple members (fig. 4), each with its own vent source within the subsequent collapsed caldera (Christiansen, 2001; Wotzlaw and others, 2015).

High precision uranium-lead (U-Pb) zircon ages (fig. 4) of Huckleberry Ridge Tuff members A, B, and C have ages of $2.0798 \pm 0.0094,2.0794 \pm 0.0047$, and $2.0783 \pm 0.0083 \mathrm{Ma}$, respectively, so all are similar in age within errors (Wotzlaw and others, 2015). This contrasts with an earlier ${ }^{40} \mathrm{Ar} /{ }^{39} \mathrm{Ar}$ study by Ellis and others (2012) that suggested a gap of $>6,000$ years between members B and C. Additional calderaforming events (fig. 4) include the Henrys Fork Caldera at $1.3004 \pm 0.0073 \mathrm{Ma}$ (U-Pb zircon age from the Mesa Falls Tuff; Wotzlaw and others, 2015) and the Yellowstone Caldera (U-Pb zircon ages of $0.6260 \pm 0.0026 \mathrm{Ma}$ from the Lava Creek Tuff, member A; $0.6292 \pm 0.0043 \mathrm{Ma}$ from the Lava Creek Tuff, member B [ages from Wotzlaw and others, 2015]; and argon (Ar) isochron ages of $0.6318 \pm 0.003 \mathrm{Ma}$ for member A and $0.6333 \pm 0.003$ Ma for member B [Matthews and others, 2015]).

Rhyolites from the YPVF are petrologically and mineralogically similar. Each cataclysmic caldera-forming eruption produced large volumes of pyroclastic material, mostly as fall deposits and densely welded ignimbrites, which are similar in major element chemistry and mineralogy; however, each is distinctive in its trace mineralogy, trace-element 


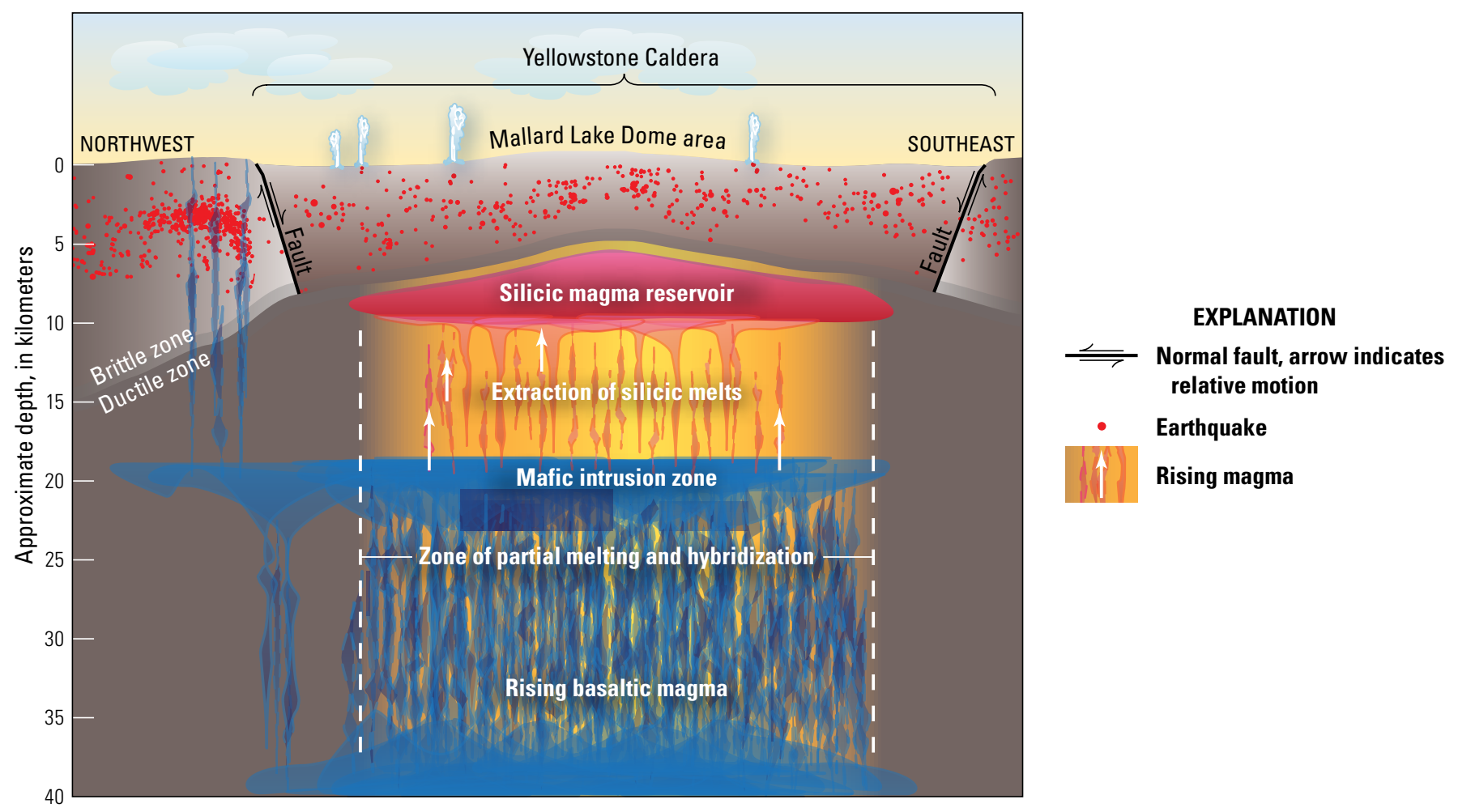

Figure 3. Schematic cross section of Yellowstone Caldera showing the bimodal magmatic system with basaltic magma underlying the silicic magma reservoir. Note the earthquake distributions (red dots). Modified from Lowenstern and Hurwitz (2008).

chemistry, isotopic values, and magnetic remanence and, therefore, can be easily fingerprinted (Reynolds, 1977; Christiansen, 2001). For example, sanidine crystals from each cataclysmic eruption have unique lead isotope signatures; they also are distinct in this regard from sanidine crystals in the younger postcaldera rhyolite deposits of Central Plateau Member of the Plateau Rhyolite (Watts and others, 2012). The deposits consist of high-silica $\left(>74\right.$ percent $\left.\mathrm{SiO}_{2}\right)$, metaluminous rhyolite emplaced as hot $\left(800\right.$ to $\left.920^{\circ} \mathrm{C}\right)$ (Hildreth and others, 1984; Loewen and Bindeman, 2016) pyroclastic flows subjected to various degrees of compaction, welding, devitrification, alteration, and degassing. Ash fallout from each of the calderaforming eruptions was extensive, reaching as far as the Mississippi River on the east and the Pacific Ocean on the west (Izett, 1981). Precaldera and postcaldera rhyolitic and basaltic lava flows are exposed below and above the caldera-forming ignimbrites and are more limited in their extent being proximal to and (or) within the caldera.

For the YPVF, much of our knowledge is based on the extensive exposures, detailed geologic mapping, and in-depth studies of the most recent and third volcanic cycle. All three volcanic cycles, each with a cataclysmic caldera-forming event in the YPVF, are interpreted as following a similar series of development stages, using the younger and better exposed third caldera-forming sequence as a model for interpreting the first two sequences (Christiansen, 1984, 2001). Caldera formation was associated with a brief climactic episode of large-volume eruptions of pyroclastic flows and ash falls resulting in the collapse of large calderas. Subsequently, the collapsed caldera is filled by rhyolitic lava flows and domes, sediments, and bodies of water. Lacustrine sediments are recognized throughout the most recent postcaldera stage (U.S. Geological Survey, 1972a). Two periods of significant volcanism are documented, between 0.60 to $0.45 \mathrm{Ma}$ and 0.260 to $0.070 \mathrm{Ma}$, following emplacement of the Lava Creek Tuff and formation of the Yellowstone Caldera. Nearly 50 postcaldera and 10 precaldera volcanic events have been documented for the Yellowstone Caldera (table 1) (Christiansen, 2001; Christiansen and others, 2007). By analogy with older silicic eruptive centers in the Snake River Plain, it is expected that the Yellowstone Caldera eventually will be host to a prolonged period of basaltic volcanism that ultimately will conceal the caldera. It also is expected that once silicic activity has ceased in the YPVF that this too will be covered with basalt flows. Lithologic logs from boreholes on the Snake River Plain and on the Yellowstone Plateau commonly include a prominent section of lacustrine sediments above the main section of rhyolites and, in the Snake River Plain, below basalt.

Hydrothermal activity presumably accompanies all stages of activity owing to magmatic heating of groundwater that then is discharged as surface hot springs, fumaroles, mud pots, geysers, and occasional rock-hurling, crater-forming (hydrothermal) 

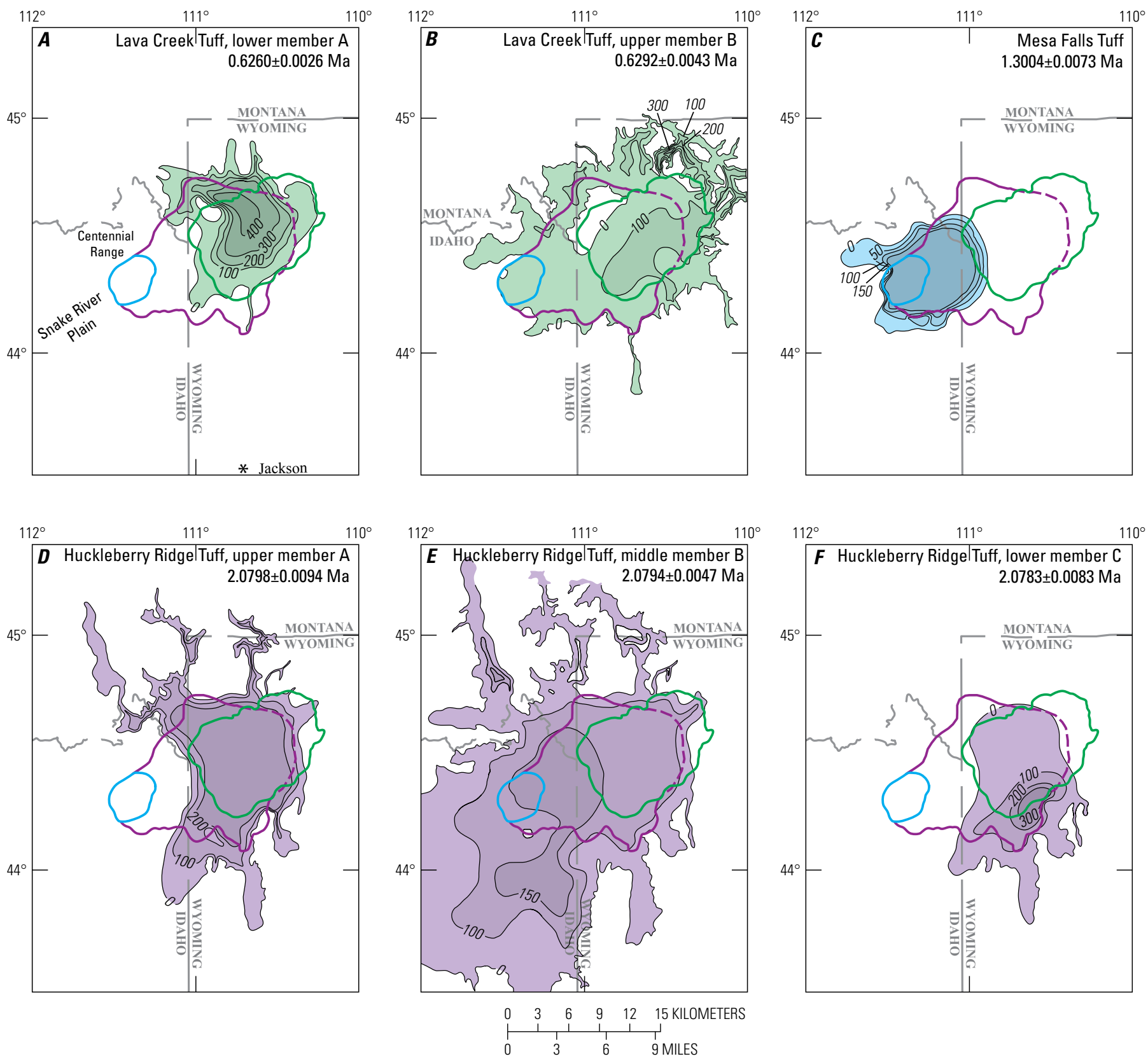

Figure 4. Map panels showing the distribution of major caldera-forming ignimbrite deposits from the three major caldera-forming eruption cycles of the Yellowstone Plateau Volcanic Field. The six map panels $(A-F)$ each cover the same greater Yellowstone area. Individual eruptive units from the three major Yellowstone caldera-forming cycles are shown with colored-shaded isopach contours (labeled in meters to denote the thickness of deposit) as follows: the third volcanic cycle (most recent), panels $A$ and $B$, shows isopach contours in shades of green for the Lava Creek Tuff of Yellowstone Group, lower unit member $A$ and upper unit member B, respectively; the associated Yellowstone Caldera is shown with the green line. The second volcanic cycle (map panel $C$ ), shows isopach contours in shades of blue for the Mesa Falls Tuff of Yellowstone Group; the associated Henrys Fork Caldera is shown with the blue line. The first volcanic cycle (oldest), map panels $D, E$, and $F$, shows isopach contours in shades of purple for the Huckleberry Ridge Tuff of Yellowstone Group, lower unit member A, middle unit member B, and upper unit member C, respectively; the associated Huckleberry Ridge Caldera is shown with the purple line. The Huckleberry Ridge Caldera margin is dashed where inferred below the Yellowstone Caldera (modified from Christiansen, 1984). Note that the Yellowstone Caldera (green line), Henrys Fork Caldera (blue line), and Huckleberry Ridge Caldera (purple line) are shown on all six panels ( $A-F$ ) for comparison. Isopach contours are from Christiansen (2001). Ages of units (in Ma, million years before present) are from Matthews and others (2015) for Lava Creek Tuff members A and B, and from Wotzlaw and others (2015) for Mesa Falls Tuff and Huckleberry Ridge Tuff members A, B, and $\mathrm{C}$. 
Table 1. Ages of key Yellowstone volcanic units.

[Table modified from Christiansen and others (2007). Ma, mega-annum (million years before present); $1 \sigma$, one standard deviation]

\begin{tabular}{|c|c|c|c|}
\hline Stratigraphic unit & Subunit & Age $(M a) \pm 1 \sigma$ & Source \\
\hline \multirow{2}{*}{ Huckleberry Ridge Tuff } & member B & $2.0794 \pm 0.0047$ & Wotzlaw and others (2015) \\
\hline & member $\mathrm{C}$ & $2.0783 \pm 0.0083$ & Wotzlaw and others (2015) \\
\hline Mesa Falls Tuff & & $1.3004 \pm 0.0073$ & Wotzlaw and others (2015) \\
\hline \multicolumn{4}{|c|}{ Postcaldera rhyolites - third-cycle intracaldera units } \\
\hline \multirow{10}{*}{$\begin{array}{l}\text { Central Plateau Member of } \\
\text { Plateau Rhyolite }\end{array}$} & Pitchstone Plateau flow & $0.0749 \pm 0.0034$ & Stelten and others (2015) \\
\hline & Grants Pass flow & $0.117 \pm 0.002$ & Stelten and others (2015) \\
\hline & Bechler River flow & $0.116 \pm 0.002$ & Obradovich (1992) \\
\hline & Summit Lake flow & $0.124 \pm 0.010$ & Christiansen and others (2007) \\
\hline & Tuff of Cold Mountain Creek & $0.143 \pm 0.005$ & Christiansen and others (2007) \\
\hline & Nez Perce Creek flow & $0.1483 \pm 0.0051$ & Christiansen and others (2007) \\
\hline & Elephant Back flow & $0.153 \pm 0.002$ & Obradovich (1992) \\
\hline & Aster Creek flow & $0.155 \pm 0.003$ & Obradovich (1992) \\
\hline & Buffalo Lake flow & $0.160 \pm 0.003$ & Obradovich (1992) \\
\hline & Mary Lake flow & $0.165 \pm 0.004$ & Obradovich (1992) \\
\hline \multirow{5}{*}{$\begin{array}{l}\text { Upper Basin Member of Plateau } \\
\text { Rhyolite }\end{array}$} & Scaup Lake flow & $0.257 \pm 0.013$ & Christiansen and others (2007) \\
\hline & Dunraven Road flow & $0.486 \pm 0.042$ & Gansecki and others (1996) \\
\hline & Canyon flow & $0.484 \pm 0.015$ & Gansecki and others (1996) \\
\hline & Tuff of Sulphur Creek & $0.479 \pm 0.010$ & Gansecki and others (1996) \\
\hline & Biscuit Basin flow & $0.516 \pm 0.007$ & Gansecki and others (1996) \\
\hline
\end{tabular}


Table 1.-Continued

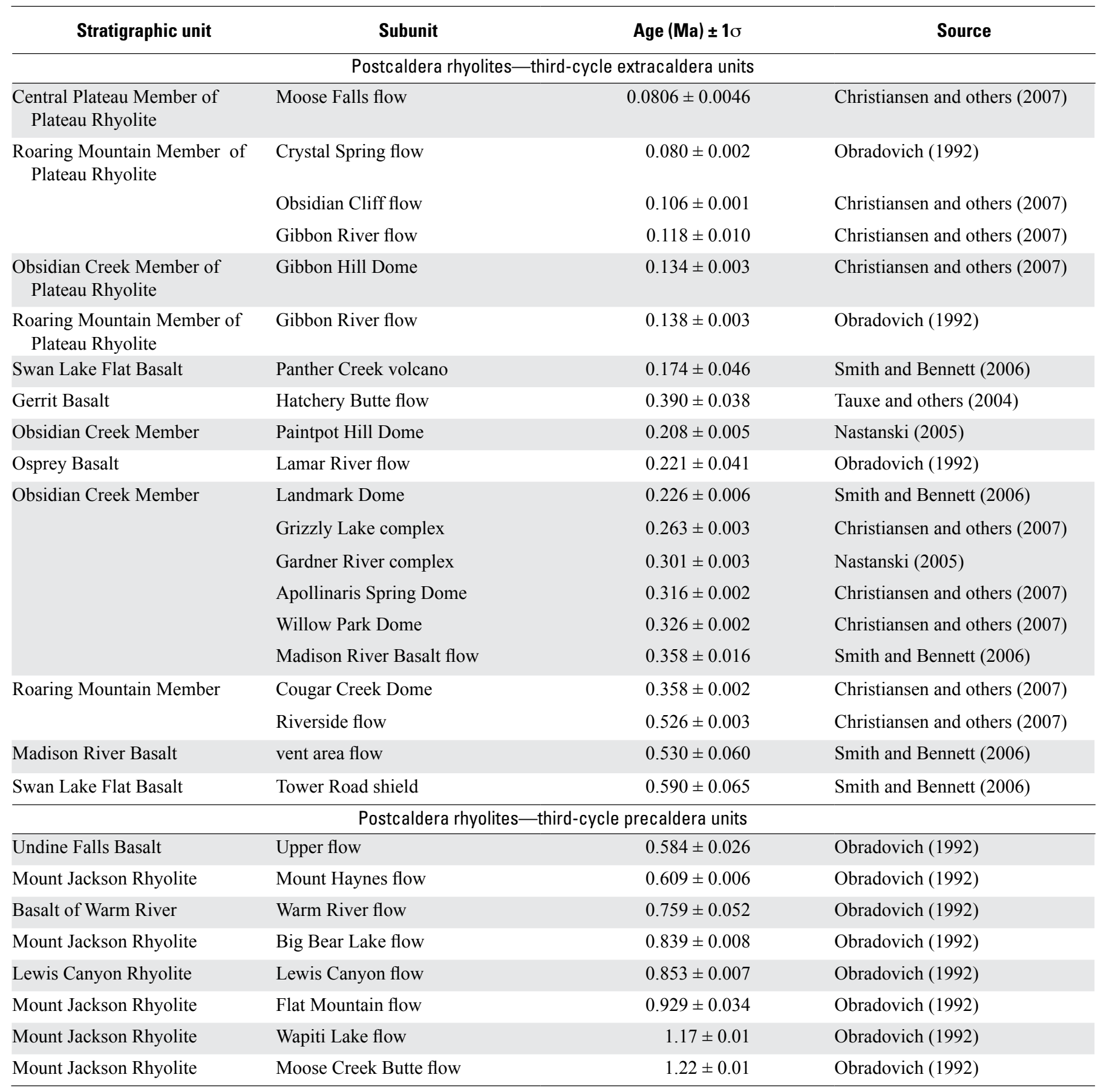


explosions. Hydrothermal activity in Yellowstone leaves extensive deposits of hydrothermally altered rock, massive sinter deposits and travertine terraces, hydrothermal explosion breccia, and zones of epithermal quartz, calcite, and pyrite mineralization.

\section{First-Cycle Volcanism}

Volcanism of the first cycle is associated with the 2.08-Ma eruption of the $2,500 \mathrm{~km}^{3}$ Huckleberry Ridge Tuff resulting in formation of a large collapsed composite caldera (Christiansen, 2001; fig. 4D-F). The Huckleberry Ridge Tuff is distributed over a broad area of the Yellowstone Plateau and south, southwest, and west into Jackson, the eastern Snake River Plain, and the Centennial Range, respectively (figs. 2, 4). Welded exposures of this unit are found more than 100 kilometers from their estimated vent sites, and fall deposits are even more widely distributed (Izett, 1981).

Detailed mapping and characterization of the ignimbrite by Christiansen (2001) identified at least three primary members (fig. 5), distinguished mineralogically and with trace elements, and erupted close in time but from separate vent sources of differing volumes within the larger caldera margin (Christiansen, 2001; Wilson, 2009; Wotzlaw and others, 2015). All members of the Huckleberry Ridge Tuff have transitional or subhorizontal magnetic polarities and nearly identical magnetic

$\boldsymbol{A}$

\begin{tabular}{|c|c|c|c|c|c|}
\hline Epoch & $\begin{array}{c}\text { Volcanic } \\
\text { cycle }\end{array}$ & Precaldera rhyolite & $\begin{array}{l}\text { Caldera-forming ash-flow tuff } \\
\text { (Yellowstone Group) }\end{array}$ & Postcaldera rhyolite & $\begin{array}{l}\text { Contemporaneous } \\
\text { plateau-marginal basalts }\end{array}$ \\
\hline \multirow{5}{*}{ Pleistocene } & \multirow[t]{3}{*}{ Third } & & & Plateau Rhyolite & $\begin{array}{c}\text { Basalts of Snake River Group } \\
\text { Osprey Basalt } \\
\text { Madison River Basalt } \\
\text { Basalt of Geode Creek } \\
\text { Swan Lake Flat Basalt } \\
\text { Gerrit Basalt } \\
\text { Falls River Basalt } \\
\text { Basalt of Mariposa Lake }\end{array}$ \\
\hline & & & Lava Creek Tuff & & \\
\hline & & $\begin{array}{l}\text { Mount Jackson Rhyolite } \\
\text { Lewis Canyon Rhyolite }\end{array}$ & & & $\begin{array}{c}\text { Undine Falls Basalt } \\
\text { Basalt of Warm River } \\
\text { Basalt of Shotgun Valley }\end{array}$ \\
\hline & Second & & & Island Park Rhyolite & Basalt of The Narrows \\
\hline & First & Rhyolite of Snake River Butte & & & Junction Butte Basalt \\
\hline
\end{tabular}

B

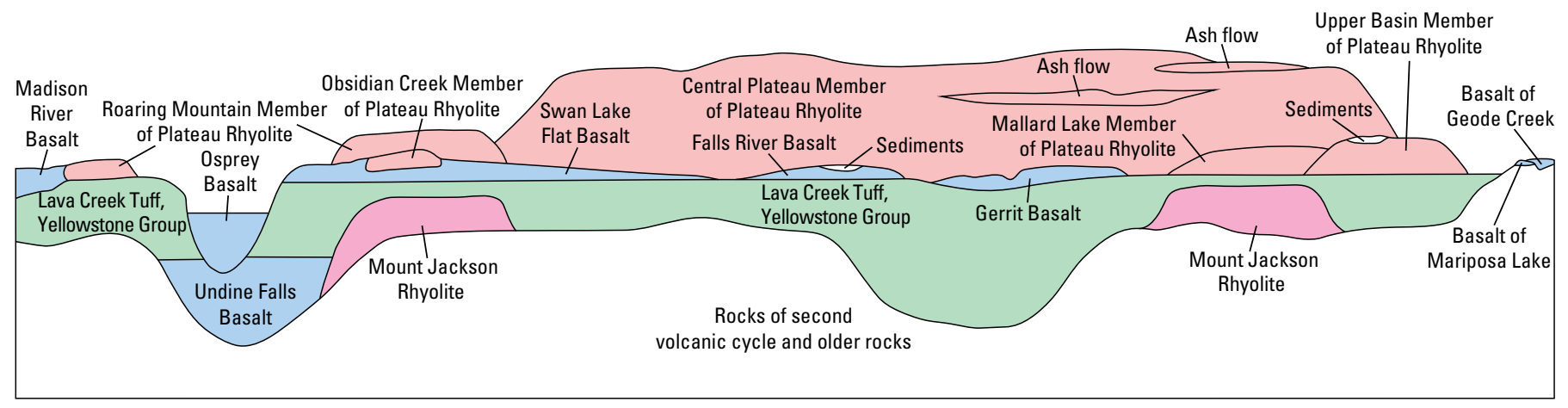

Figure 5. Stratigraphic correlation diagram and generalized cross section of third-cycle volcanic rocks of the Yellowstone Plateau Volcanic Field (YPVF). A, Stratigraphic correlation diagram of the YPVF. Stratigraphic units are shown in color for illustrative purposes: rhyolitic lavas and minor ash deposits are shown in shades of pink; basaltic lava flows are shown in shades of blue. The major ignimbrites of the YPVF are shown in purple (Huckleberry Ridge Tuff of Yellowstone Group), turquoise (Mesa Falls Tuff of Yellowstone Group), and green (Lava Creek Tuff of Yellowstone Group). $B$, Generalized cross section diagram of third-cycle volcanic rocks of the YPVF. The Yellowstone Caldera formed either late in the eruption of the Lava Creek Tuff or immediately after the eruption of the Lava Creek Tuff. Basalt and the Obsidian Creek and Roaring Mountain Members of the Plateau Rhyolite occur only outside the caldera. Colors used are similar to those in 5A. Modified from Christiansen (2001). 
inclination and declination (Reynolds, 1977), implying that all members were erupted within a short time interval. A recent study by Myers and others (2016) indicates that the eruption may have begun haltingly, as a series of fall deposits providing evidence for slow ascent and multiple active vents prior to the climactic pyroclastic flow activity.

In a few exposures around the topographic margin of the 2.08-Ma caldera, precaldera rhyolites and basalts are overlain by the Huckleberry Ridge Tuff. Examples include the 2.2-Ma Snake River Butte rhyolitic dome (Christiansen, 2001; Wotzlaw and others, 2015) and the extensive Junction Butte Basalt (near Tower Junction) and approximately 2-Ma basalts from Gardiner north into the Paradise Valley, including the 2.2-Ma basalt of Heburn Mesa (exposed from Gardiner north into the Paradise Valley; Smith and others, 1995).

\section{Second-Cycle Volcanism}

Second-cycle volcanism culminated with a smaller calderaforming event that produced the moderate volume $\left(500 \mathrm{~km}^{3}\right)$ 1.30-Ma Mesa Falls Tuff and the $\sim 15$ - by $\sim 30$-km Henrys Fork Caldera nested in the southwest margin of the first-cycle caldera (figs. 2, 4, 5) (Christiansen, 2001). A few precaldera rhyolitic lavas and an ignimbrite are exposed below the Mesa Falls Tuff on the flanks of its caldera. Inside the Henrys Fork Caldera are several postcaldera rhyolitic domes that erupted shortly after the cataclysmic eruption and are reversed in magnetic polarity, as is the Mesa Falls Tuff (Reynolds, 1977; Christiansen, 2001). The floor of the Henrys Fork Caldera is filled with basaltic lava flows, some of which erupted through the caldera floor by $0.5 \mathrm{Ma}$ (Abedini, 2009). Apparently, the rhyolitic magma chamber associated with eruption of the 1.30-Ma Mesa Falls Tuff had crystallized sufficiently by $0.5 \mathrm{Ma}$ to become brittle and allow for the ascent of the basaltic magma to rise along fractures and fill the floor of the caldera.

\section{Third-Cycle Volcanism}

The 0.63-Ma Yellowstone Caldera is the youngest large (greater than several tens of kilometers in diameter) caldera in the 750-km-long Yellowstone Plateau-Snake River Plain volcanic province and the third cycle of volcanism in the YVPF (fig. 5). The third cycle provides a good example of the general evolutionary sequence of caldera development within a volcanic field (fig. 6) in this part of the volcanic province.

About 1.23 Ma, the main focus of volcanism shifted from the Island Park area in the southwestern YPVF to the northeast to initiate the third-cycle volcanism culminating $0.63 \mathrm{Ma}$ in the eruption of the Lava Creek Tuff, resulting in collapse and formation of the Yellowstone Caldera.

\section{Precaldera Volcanism}

Examples of the earliest volcanism associated with the third-cycle Yellowstone Caldera (figs. $5 D-F, 6 A$; table 1) include voluminous $\left(\geq 10 \mathrm{~km}^{3}\right)$, reversely magnetized, rhyolitic lava flows, such as of the Lewis Canyon Rhyolite $(1.16 \pm 0.01 \mathrm{Ma}$ to $0.853 \pm 0.007 \mathrm{Ma}$; Obradovich, 1992) and the reversely magnetized sections of the Mount Jackson Rhyolite $(0.839 \pm$ 0.008-Ma Harlequin Lake Flow; Christiansen and Blank, 1972; Obradovich, 1992; Finn and Morgan, 2002). Volcanism continued with eruptions of the upper sections of the normally magnetized Mount Jackson Rhyolite and Undine Falls Basalt. The Undine Falls Basalt is interlayered with fluvial gravels which flowed down paleo-valleys from the north and may have erupted shortly before the Lava Creek Tuff (table 1) (Christiansen, 2001).

\section{Cataclysmic Caldera-Forming Volcanism}

Cataclysmic eruptions at 0.63 Ma produced the voluminous $\left(1,000 \mathrm{~km}^{3}\right.$ ) Lava Creek Tuff (fig. $4 A-B, 6$ ), a densely welded (in most exposures) rhyolitic ignimbrite, as well as a similar volume of globally distributed ash (Izett, 1981; Mastin and others, 2014). This event resulted in formation of $75-\mathrm{km}$ by $45-\mathrm{km}$ Yellowstone Caldera. The Lava Creek Tuff has two distinctive members (a lower member, A, and a later erupted and upper member, B) that, like most rhyolites of the YPVF, carry phenocrysts of quartz, sanidine (about $\mathrm{Or}_{50-55}$ ), and subordinate sodic plagioclase (about $\mathrm{An}_{20}$ ). Minor phenocrysts include magnetite, ilmenite, clinopyroxene (ferroaugite), fayalite, iron-rich hornblende, zircon, chevkinite, and allanite. Hornblende is a rare constituent of member B but is the predominant mafic constituent in glassy portions of both the lower and upper parts of member A (Christiansen, 2001).

The two members represent different eruptive events (Christiansen, 2001) separated by a very short period of time (Matthews and others, 2015). Isopach maps show each member erupted from different vent areas within the collapsed caldera (fig. $4 A-B$ ) and that they are broadly distributed as pyroclastic flows within and outside of the topographic margin of the Yellowstone Caldera (fig. 6). Detailed mapping and lithologic logs from several U.S. Geological Survey (USGS) research boreholes drilled inside the caldera support this interpretation (Christiansen, 2001). Each member differs slightly in terms of trace mineralogy and trace-element chemistry. Member $\mathrm{A}$, similar in volume to member $\mathrm{B}$, was emplaced onto a topography of high relief and is exposed on the western and north central margins of the caldera restricted to an initial area estimated at 3,240 $\mathrm{km}^{2}$ (Christiansen, 2001). Member A also is mapped on the Sour Creek structural dome and identified in several research boreholes in the park (White and others, 1975).

Member B has a greater distribution around the Yellowstone Caldera and beyond, given that pyroclastic sheets from member A filled in preexisting rugged relief. The initial area of the pyroclastic flow deposits is estimated to cover approximately $7,300 \mathrm{~km}^{2}$. Exposures of member B are found extensively to the west and southwest on the Snake River Plain and the northeast edges of the Heise Volcanic Field, and also found on the western slopes of the Teton Range, south into Jackson, and east on the slopes of the Eocene Absaroka Range. Member B also is exposed above member A north and west of 

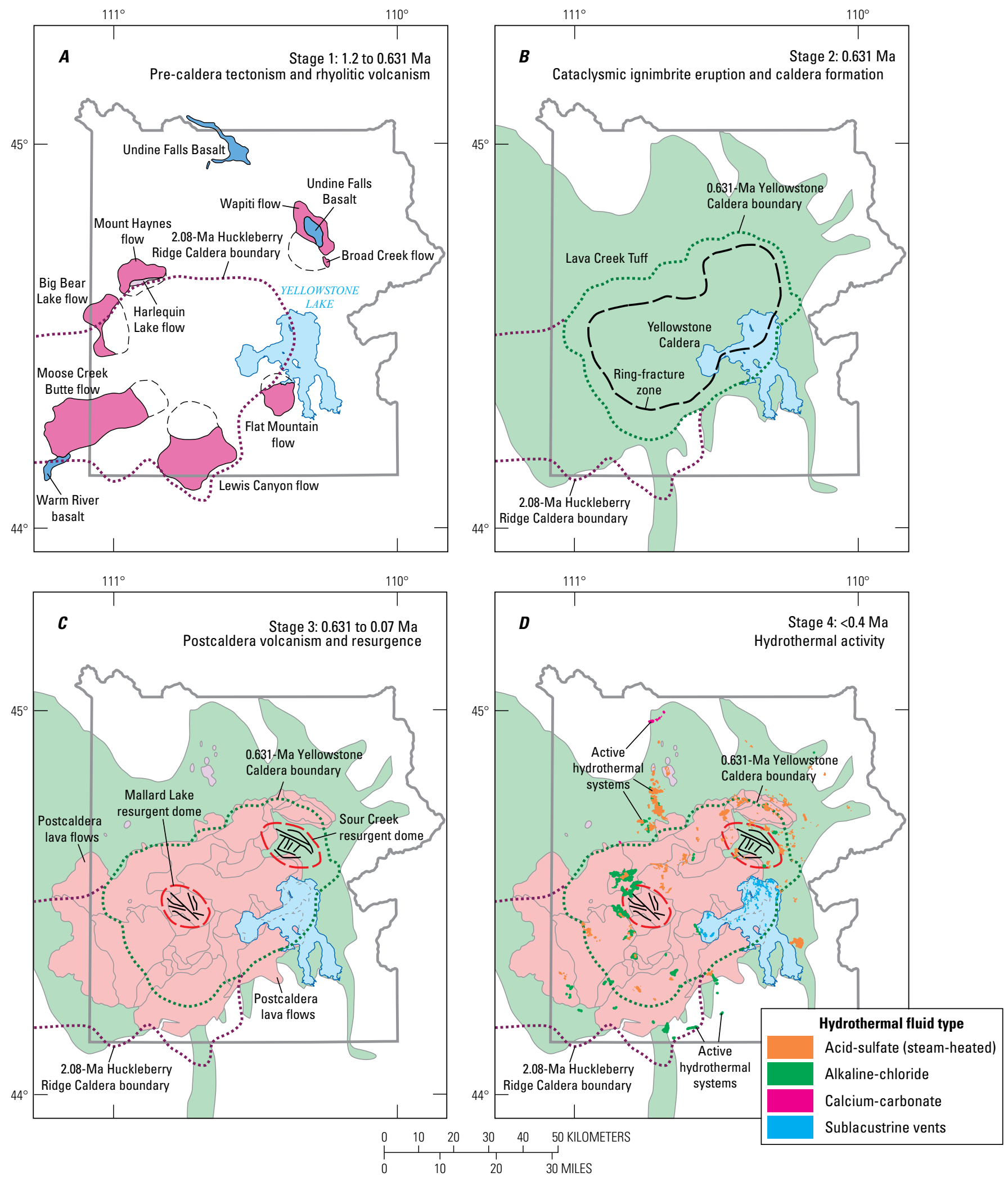

Figure 6. Maps displaying the stages of evolution of the third-cycle Yellowstone Caldera associated with the eruption of the Lava Creek Tuff of Yellowstone Group. A, Stage 1 precaldera tectonism and volcanism; basaltic lava flows shown in blue, rhyolitic lava flows shown in dark pink; extent of rhyolitic lava flows into precaldera area uncertain and shown by dashed lines. $B$, Stage 2 cataclysmic ignimbrite eruption and caldera formation; extent of Lava Creek Tuff shown in green. C, Stage 3 postcaldera volcanism and resurgence; postcaldera lava flows shown in light pink the two resurgent domes associated with the Yellowstone Caldera are outlined in dashed red lines with black interior lines representing faults. $D$, Stage 4 hydrothermal activity, shown in orange, green, magenta, and blue. Modified from Finn and Morgan (2002). 
the Yellowstone Caldera and on the Sour Creek resurgent dome (fig. 6) and elsewhere above eroded terrains.

Major collapse of the Yellowstone Caldera is interpreted to have occured after emplacement of the Lava Creek Tuff and not coeval with the eruption (Christiansen, 2001). Several lines of evidence support this interpretation, including (1) thickness measurements of intracaldera Lava Creek Tuff member B on Sour Creek Dome are somewhat irregular, yet they do not exceed the thickness of the Lava Creek Tuff exposed outside the topographic caldera margin on the nearby northeast caldera rim; (2) features along the northwest caldera wall include a large block of Lava Creek Tuff member A that has slumped into the caldera. Thickness measurements of the Lava Creek Tuff member A are similar in the slumped block to those on the outer caldera wall. Furthermore, features in member $A$ in the slump block suggest that collapse at this location occurred shortly after emplacement while the ignimbrite was still welding and crystallizing (Christiansen, 2001). Similar relationships to ignimbrite emplacement and caldera collapse also have been documented for ignimbrites and caldera margins at the Heise Volcanic Field on the Snake River Plain (Morgan and McIntosh, 2005).

\section{Postcaldera Volcanism (Plateau Rhyolite)}

The Yellowstone Caldera hosts two resurgent areas, the Mallard Lake Dome and the Sour Creek Dome, each interpreted as the collapsed vent areas for Lava Creek Tuff members A and $\mathrm{B}$, respectively, that later became resurgent after eruption (Christiansen, 2001). These features are associated with magmatic resurgence and early postcaldera lavas and tuffs emplaced shortly after caldera collapse (figs. 1, 6C; table 1). Each resurgent dome has a complex and somewhat different history, as well, discussed in Christiansen (2001). The larger subsided caldera subsequently filled with sediments, streams, lakes, rhyolitic lava flows, domes, and subordinate pyroclastic flows.

The postcaldera rhyolites are referred to as the Plateau Rhyolite (fig. 5) and are separated into five different calderarelated members (Central Plateau Member, Mallard Lake Member, Upper Basin Member, Roaring Mountain Member, and Obsidian Creek Member), based on similar geographic distribution, mineralogy, and age (table 1) (Christiansen 2001). Two major phases of postcaldera volcanism are recognized (Christiansen, 2001); the oldest postcaldera rhyolites are designated as the Upper Basin Member and were emplaced shortly after caldera formation continuing until around $0.45 \mathrm{Ma}$. Following a long period of quiescence, renewed volcanic activity began $\sim 0.25 \mathrm{Ma}$ and continued until $\sim 0.07 \mathrm{Ma}$ in both intracaldera settings (Central Plateau Member and the older Mallard Lake Member) and outside the caldera along tectonically active zones (extracaldera units Obsidian Creek Member and Roaring Mountain Member). In all, at least $600 \mathrm{~km}^{3}$ of rhyolite erupted since the Yellowstone Caldera collapsed (Christiansen and others, 2007); the flows are some of the most voluminous rhyolitic lava flows on Earth, many in excess of several tens of cubic kilometers, extending up to $30 \mathrm{~km}$ from their source vents, and having thicknesses in excess of $100 \mathrm{~m}$.

\section{Upper Basin Member}

Rhyolitic flows associated with the Upper Basin Member of the Plateau Rhyolite group represent the oldest units in the postcaldera sequence. They are exposed west and north of the Sour Creek Dome adjacent to the northeastern topographic margin of the Yellowstone Caldera and to the south and west of the Mallard Lake Dome (Christiansen, 2001). They are typically rich in plagioclase phenocrysts compared to younger flows of the Plateau Rhyolite.

Flows of the Upper Basin Member are mainly twofeldspar rhyolites in which plagioclase phenocryst abundance equals or exceeds that of sanidine. The plagioclase phenocrysts are notably sieved and somewhat more calcic (as much as approximately $\mathrm{An}_{30}$ ) than in the younger plagioclase-bearing flows of the Central Plateau Member (generally about $\mathrm{An}_{20}$ ).

The early postcaldera rhyolites are remarkable for their low magmatic $\delta^{18} \mathrm{O}$ values observed in whole rock, glass, and crystals (Hildreth and others, 1984. 1991; Bindeman and Valley, $2000,2001) . \delta^{18} \mathrm{O}$ values of quartz, sanidine, zircon, and glass are up to 6 per mil lower than typical magmatic values (fig. 7) and are attributed to melting and incorporation of buried rhyolite that was altered by meteoric hydrothermal fluids (Bindeman and Valley, 2001).

In the Canyon area along the northern topographic margin of the caldera, the Upper Basin Member (Christiansen, 2001; Gansecki and others, 1996) includes the Canyon flow (0.484 \pm $0.015 \mathrm{Ma})$, the tuff of Sulphur Creek $(0.479 \pm 0.010 \mathrm{Ma})$, and the Dunraven Road flow (0.486 $\pm 0.042 \mathrm{Ma})$. Here, mapped within the Upper Basin Member, is the undated tuff of Uncle Tom's Trail. Based on petrography and major and trace-element geochemistry, Pritchard and Larson (2012) argue that the tuff of Uncle Tom's Trail is equivalent to the tuff of Sulphur Creek.

To the southwest, rhyolitic lava of the Biscuit Basin flow $(0.516 \pm 0.007 \mathrm{Ma}$; Gansecki and others, 1996), exposed on the northern and western flank of Mallard Lake Dome, is interpreted as most likely predating the initial uplift of the Mallard Lake Dome. Given the glassy, hydrated, and fractured character of the perlite exposed, the Biscuit Basin flow most likely was emplaced in a body of water, perhaps in the moat zone of the collapsed caldera. Bindeman and Valley (2001) suggest the Biscuit Basin flow, previously considered to be a single lava flow (Christiansen, 2001), represent three separate, independent flows or domes and divide the flow into three units based on three separate outcrops: the North, Middle, and South Biscuit Basin flows. Most work has been done on Middle Biscuit Basin flow, directly east of Midway Geyser Basin. The North Biscuit Basin flow consists of rocks very similar to the Middle Biscuit Basin flow: high-silica rhyolites with subequal phenocrystic plagioclase and sanidine and less abundant quartz. The South Biscuit Basin flow is different, having more abundant and larger phenocrysts and a younger age $(0.261 \pm 0.017 \mathrm{Ma}$; Bindeman and Valley, 2001). Additionally, Girard and Stix (2009) provide evidence for a fourth flow that they name the East Biscuit Basin flow; this lava flow has distinctly lower $\mathrm{SiO}_{2}$ (71-72 weight [wt.] percent) and lacks quartz and sanidine phenocrysts. 
$\boldsymbol{A}$

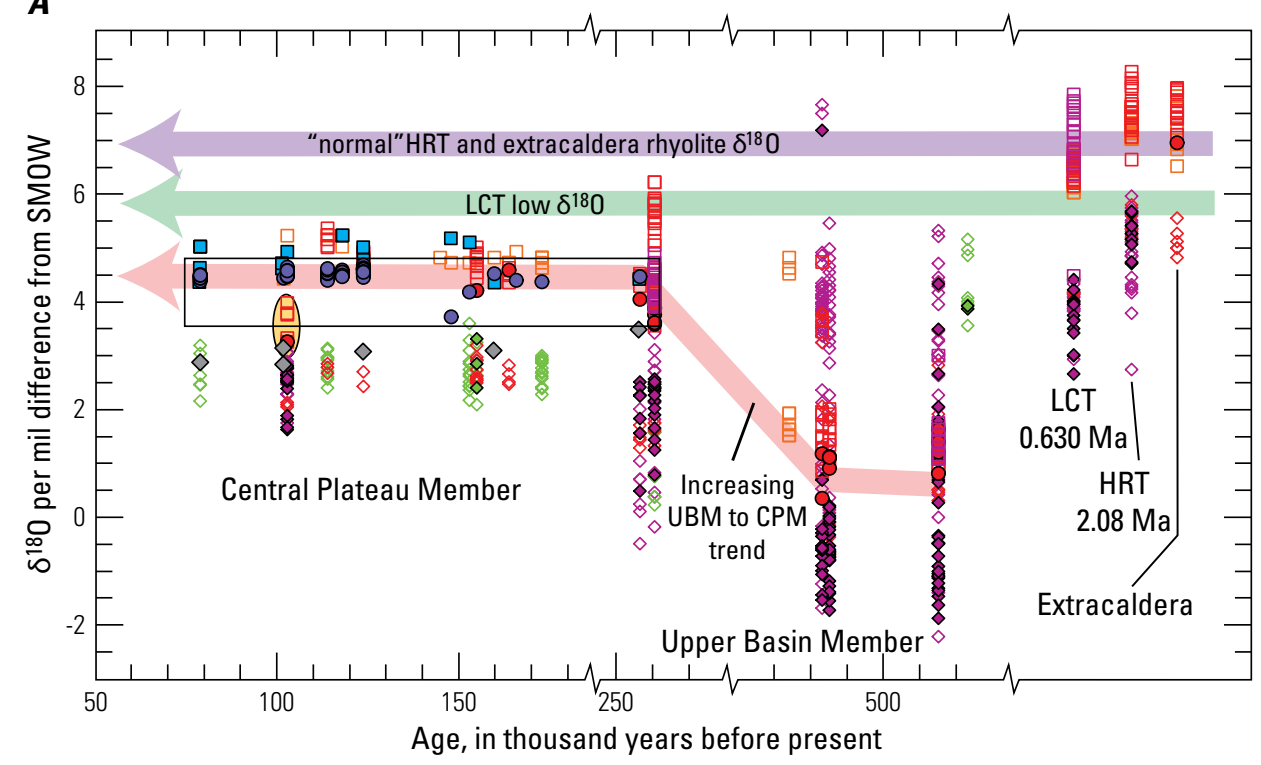

B

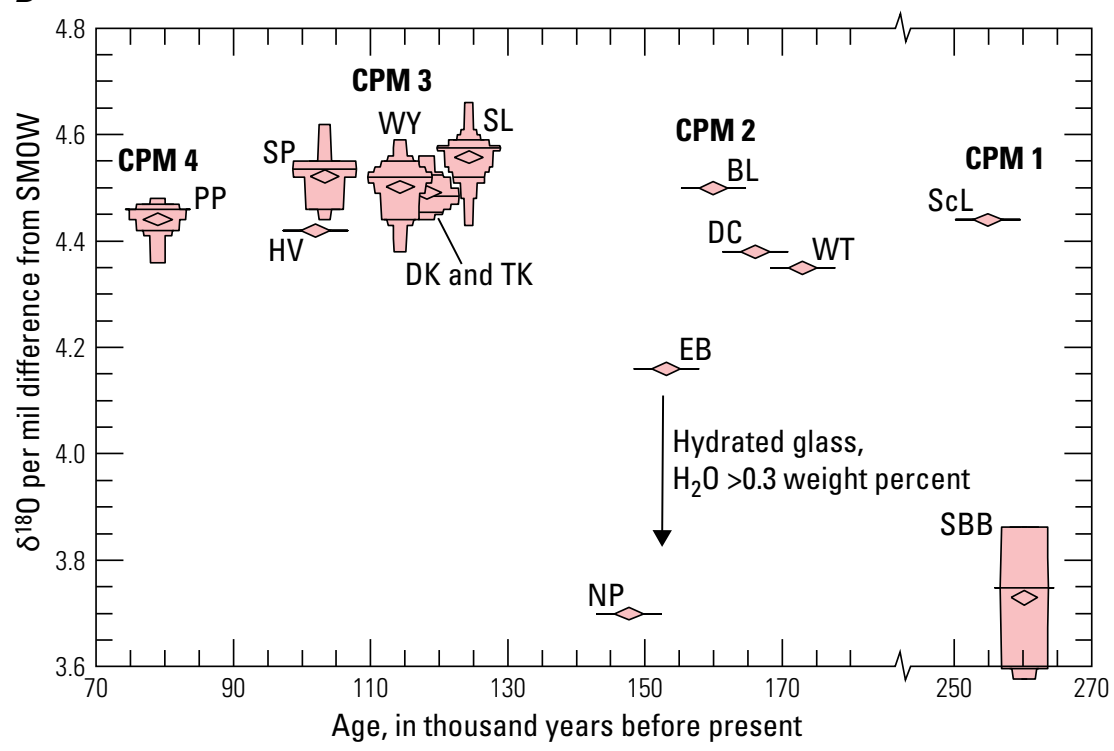

EXPLANATION

Glass

- Bindeman and Valley (2001)

- Loewen and Bindeman (2015) Quartz

$\square \quad$ Bindeman and others (2008)

$\square \quad$ Bindeman and Valley (2001)

$\square \quad$ Hildreth and others (1984)

口 Loewen and Bindeman (2015)

Clinopyroxene

$\diamond \quad$ Loewen and Bindeman (2015) Zircon core

$\diamond \quad$ Bindeman and others (2008)

$\diamond \quad$ Bindeman and Valley (2001)

Watts and others (2012)

Zircon rim

- Bindeman and others (2008)

$\diamond \quad$ Watts and others (2012)

Figure 7. Plots of oxygen isotope systematics and ages of Yellowstone rhyolites including glass and minerals from postcaldera rhyolites. $A$, The broad green arrow represents the range in oxygen isotope compositions of normal Huckleberry Ridge Tuff (HRT) of Yellowstone Group and extracaldera rhyolite; the broad orange-tan arrow represents the range in oxygen isotope compositions for the Lava Creek Tuff (LCT) of Yellowstone Group; the yellow arrow represents the increasing oxygen isotope trend from the Upper Basin Member to the Central Plateau Member of the Plateau Rhyolite. Range in oxygen isotope compositions of the Upper Basin Member extend to much lower values than other samples. This reflects assimilation of hydrothermally altered rocks into magmas created after formation of the Yellowstone Caldera. "Kinks" in horizontal axes indicate a break where some of axis has been skipped, but the scale remains constant. $B$, Central Plateau Member rhyolites (black outlined box on $A$ ) have moderately low $\delta^{18} 0$ values relative to normal igneous values. Box and whisker symbols are shown for units having more than three analyses. Diamonds indicate mean values and horizontal lines indicate median. Modified from Loewen and Bindeman (2015). Abbreviations: CPM 1 to CPM 4, Central Plateau Member divided into four age groupings; BL, Buffalo Lake flow; DC, Dry Creek flow; DK, Douglas Knob; EB, Elephant Back flow; HV, Hayden Valley flow; NP, Nez Perce flow; PP, Pitchstone Plateau flow; SBB, South Biscuit Basin flow; ScL, Scaup Lake flow; SL, Summit Lake flow; SP, Solfatara Plateau flow; TK, Trischman Knob; UBM, Upper Basin Member; WT, West Thumb flow; WY, West Yellowstone flow; $\delta^{18} \mathrm{O}$, ratio of isotope ${ }^{18} \mathrm{O}$ to ${ }^{16} \mathrm{O}$ compared to that of a standard; per mil (parts per thousand); SMOW, standard mean ocean water. 
The Scaup Lake flow is high-silica rhyolite lava exposed on the south flank of Mallard Lake Dome and extends southeast to Scaup Lake. Christiansen and others (2007) provide an ${ }^{40} \mathrm{Ar} /{ }^{39} \mathrm{Ar}$ age of $0.257 \pm 0.013 \mathrm{Ma}$ for the Scaup Lake flow. Girard and Stix (2009) provide evidence that the South Biscuit Basin flow, exposed near Mystic Falls, and the Scaup Lake flow are not only the same age but are petrographically similar, suggesting that the South Biscuit Basin flow is distinct from the other Biscuit Basin flow units and may be equivalent to the Scaup Lake flow (Till and others, 2015).

Data from trace-element geochemistry suggest each of the Biscuit Basin flows (North, Middle, South, and East) are derived from separate magma batches (Girard and Stix, 2009). They propose a petrogenetic model whereby replenishment of the magma chamber with silicic liquid causes melting of low- $\delta^{18} \mathrm{O}$ hydrothermally altered rhyolite in subsided blocks, forming small distinct batches of liquid-rich magma.

At Mallard Lake Dome, a significant hiatus in volcanic activity (up to 0.1 million years) occurred between the eruption of the 0.257-Ma Scaup Lake flow and the beginning of the next series of volcanism, the Central Plateau Member, beginning around $0.165 \mathrm{Ma}$ and continuing until around $0.070 \mathrm{Ma}$.

\section{Mallard Lake Member}

The Mallard Lake Member, a lava capping the Mallard Lake Dome and adjacent to the 0.257-Ma Scaup Lake flow, is considered to be sufficiently different from rhyolitic flows in the Upper Basin and Central Plateau Members to be considered a distinct member of the Plateau Rhyolite. Recent ${ }^{40} \mathrm{Ar} /{ }^{39} \mathrm{Ar}$ ages of this flow (0.164 $\pm 0.014 \mathrm{Ma}$; Christiansen and others, 2007) suggest that its eruption may have coincided with or shortly predated the earliest volcanic events in the Central Plateau Member, some units of which partially cover the Mallard Lake flow. Its phenocryst assemblage of quartz and sanidine, sparse plagioclase, and trace minerals including opaque oxides, clinopyroxene, and orthopyroxene is distinct (Christiansen, 2001) from both the Upper Basin and Central Plateau Members. Eruption and doming of the Mallard Lake flow is interpreted now as occurring with or immediately after the earliest eruptions of the Central Plateau Member and, certainly, prior to younger events in the Central Plateau Member. Resurgent doming likely precedes the actual emplacement of Mallard Lake flow and continues to the present, as evidenced by its many active graben-like faults (Christiansen, 2001).

\section{Central Plateau Member}

Christiansen (2001) and Christiansen and others (2007) summarized ages and geological characteristics of units in the Central Plateau Member postcaldera rhyolites (table 1). Ages of these rhyolites range from $0.075 \mathrm{Ma}$ to $0.173 \mathrm{Ma}$; the lavas are largely responsible for infilling of the Yellowstone Caldera (fig. 6). Individual rhyolites of the Central Plateau Member have areas up to $70 \mathrm{~km}^{2}$, flow lengths to $37 \mathrm{~km}$, and thicknesses in excess of $300 \mathrm{~m}$. Total aggregate eruptive volumes are estimated at 360 to $600 \mathrm{~km}^{3}$.
Christiansen and others (2007) summarize volcanic activity forming the Central Plateau Member as follows. Younger postcaldera rhyolitic volcanism began with extrusion of the rhyolitic Mallard Lake flow onto the Mallard Lake Dome, the western resurgent dome, one of two, in the Yellowstone Caldera (fig. 1).

The Central Plateau Rhyolites appear to have erupted in five episodes at about $0.164 \pm 0.005,0.152 \pm 0.003,0.114$ $\pm 0.002,0.102 \pm 0.005$, and $0.072 \pm 0.004 \mathrm{Ma}$ (Christiansen, 2001; Christiansen and others, 2007). In addition, at least two significant pyroclastic eruptions occurred within the caldera, emplacing the tuffs of Bluff Point and Cold Mountain Creek. The tuff of Bluff Point (estimated eruption volume $\sim 50 \mathrm{~km}^{3}$ ) is interpreted to have formed the 8-km-diameter West Thumb Caldera in the western part of Yellowstone Lake (Christiansen, 2001).

Rhyolites of the younger postcollapse sequence are generally similar in mineralogy and chemistry (Christiansen, 2001; Vazquez and Reid, 2002). These are high-silica rhyolites of relatively uniform bulk chemical composition (table 2). The principal phenocrysts are quartz and sanidine with minor plagioclase in a few flows. Minor iron-rich clinopyroxene (ferroaugite) and magnetite are present, and fayalite occurs in the older units. Hydrous phenocrysts are not present.

The Central Plateau Rhyolites have lower $\delta^{18} \mathrm{O}$ values than typical rhyolites, but are not strongly ${ }^{18} \mathrm{O}$-depleted like the units of the older Upper Basin Member. Loewen and Bindeman (2015) summarize oxygen isotope and age systematics for Yellowstone rhyolites (fig. 7), showing that the Upper Basin Member rhyolites have the lowest $\delta^{18} \mathrm{O}$ values. Central Plateau Member rhyolites have average $\delta^{18} \mathrm{O}$ values of approximately 4.5 per mil, which is about 1.5 per mil lower than Lava Creek Tuff and about 2.5 per mil lower than "normal" rhyolites.

Recent petrologic and geochemical studies of Central Basin Member rhyolites by Befus and Gardner (2016), Girard and Stix (2010, 2012), Vazquez and others (2009), Loewen and Bindeman (2015), Stelten and others (2015), and Watts and others (2012) have refined the magmatic history of these units. Girard and Stix (2010) suggest that melting of hydrothermally altered low- $\delta^{18} \mathrm{O}$ rhyolitic protolith began at $0.25 \mathrm{Ma}$, and a large differentiating crystal mush formed beneath much of the caldera. Further input of heat and silicic magma in this mush increased the degree of melting, forming separate crystalpoor magma batches that erupted to form the rhyolites. Girard and Stix (2010) further show enrichment in elements such as niobium $(\mathrm{Nb})$, yttrium $(\mathrm{Y})$, and heavy rare earth elements (HREEs), and depletion in strontium (Sr), barium (Ba), and cerium/ytterbium ratios $(\mathrm{Ce} / \mathrm{Yb})$ with time, suggesting that the Scaup Lake and South Biscuit Basin flows are the most primitive and the Pitchstone Plateau flow, the youngest, is most evolved, as earlier suggested by Hildreth and others (1984, 1991).

Volatiles in Central Plateau Member rhyolites were explored by Befus and Gardner (2016). Through a study of phenocryst-hosted glass inclusions, they found consistent chlorine $(\mathrm{Cl})(1,100 \pm 100$ parts per million [ppm]) and 


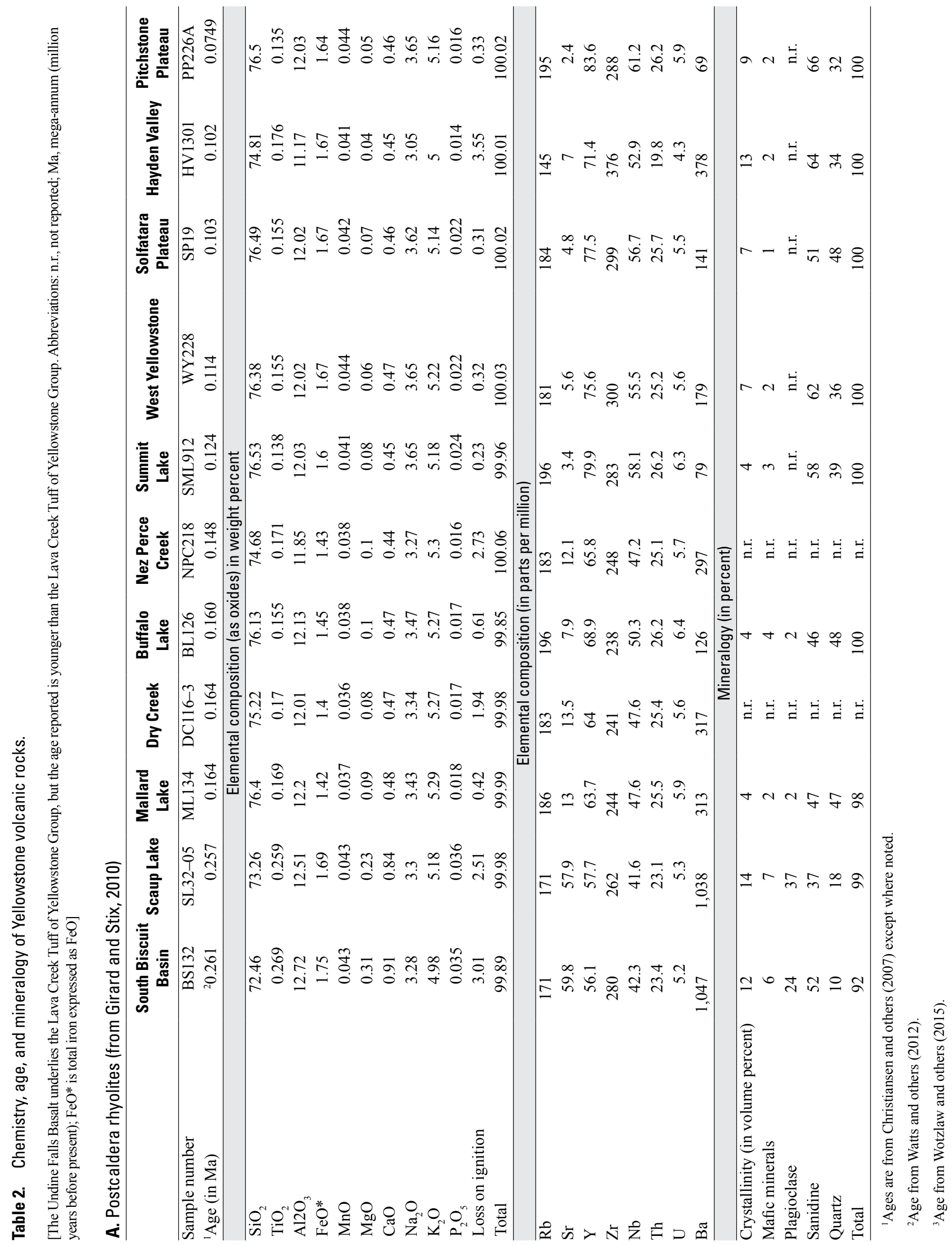




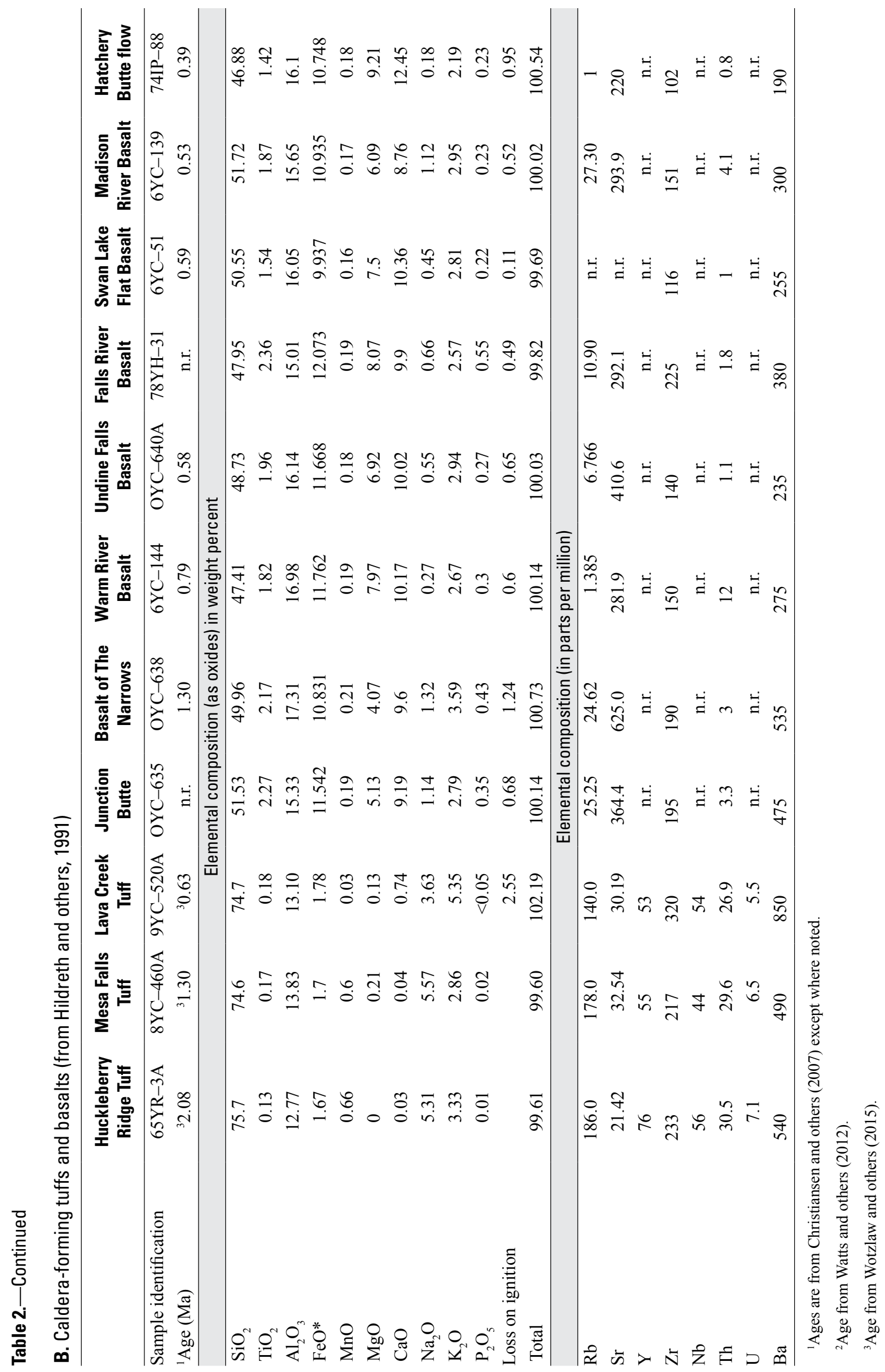


fluorine $(\mathrm{F})(1,900 \pm 100 \mathrm{ppm})$ abundance but greater variation in $\mathrm{H}_{2} \mathrm{O}$ and $\mathrm{CO}_{2}$. Water concentrations generally fell to less than 3 total wt. percent, but some units (for example, the tuff of Bluff Point) consistently contained higher $\mathrm{CO}_{2}$ concentrations (up to $>600 \mathrm{ppm}$ ) compared with other units (fig. 8). If the $\mathrm{H}_{2} \mathrm{O}$ and $\mathrm{CO}_{2}$ values represent pristine values for the glass inclusions, then most pre-eruption magma crystallization would be constrained at 50 to 150 megapascals (MPa) (fig. 8). Myers and others (2016) interpreted low $\mathrm{H}_{2} \mathrm{O}$ in Huckleberry Ridge Tuff glass inclusions to result from pre-eruption diffusive loss; they re-calculated pre-eruption $\mathrm{H}_{2} \mathrm{O}$ values to 4 to $5 \mathrm{wt}$. percent. It is conceivable that the slow-rising lavas of the Central Plateau Member also may have suffered from some diffusive loss of volatiles from phenocryst-hosted glass inclusions. If so, some of the pressures inferred from figure 8 would be too low and pre-eruption storage would be consistent with the upper pressures estimated by Befus and Gardiner (2016). Regardless, the relatively high $\mathrm{CO}_{2}$ concentrations are consistent with close association of the Yellowstone rhyolites with $\mathrm{CO}_{2}$-rich mantlederived basalt that underlies the Yellowstone silicic magma chamber (Christiansen, 2001; Werner and Brantley, 2003).

Befus and Gardner (2016) note that the tuffs of Cold Mountain Creek and Bluff Point deviate from the systematic traceelement fractionation observed in the rhyolite flows. Specifically, trace elements in the groundmass glass of those units are more primitive than in melt inclusions, providing strong evidence for pre-eruptive mixing with a less-evolved batch of rhyolite, perhaps similar to the low-silica rhyolite of East Biscuit Basin flow (Girard and Stix, 2009; 2012 Watts and others, 2012). Befus and Gardner (2016) speculate that magma mixing triggered the explosive eruptions of the tuff of Cold Mountain Creek and the tuff of Bluff Point. Interestingly, the tuff of Bluff Point also appears to be the most volatile-rich (fig. 8) of the Central Plateau Member units (Befus and Gardner, 2016).

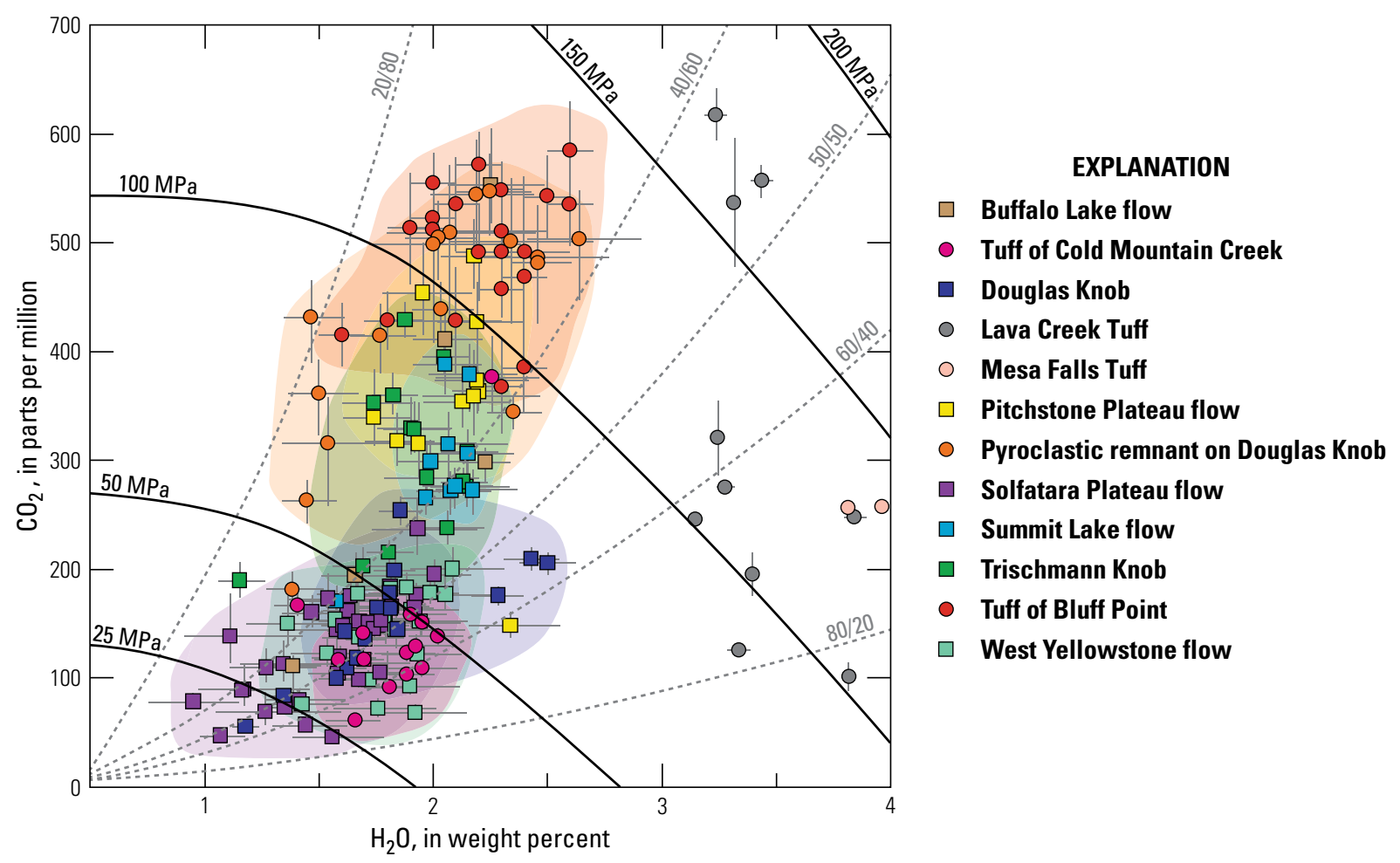

Figure 8. Plot of dissolved volatile contents of quartz-hosted glass inclusions of pre-eruptive magmas as determined through analysis of silicate melt inclusions trapped in phenocrysts from Yellowstone lavas and tuffs. Dark black lines represent isobars based on volatile solubility. Dashed lines are labeled with the $\mathrm{H}_{2} \mathrm{O} / \mathrm{CO}_{2}$ ratios of the coexisting vapor for volatile-saturated melts. The tuff of Bluff Point and pyroclastic materials on Douglas Knob have the highest $\mathrm{CO}_{2}$ concentrations and apparent crystallization pressures. Vertical and horizontal lines on data points indicate range in values. Colored fields represent the general distribution of each unit. Modified from Befus and Gardner (2016). Abbreviations: $\mathrm{CO}_{2}$, carbon dioxide; $\mathrm{H}_{2} \mathrm{O}$, water; $\mathrm{MPa}$, megapascal. 


\section{Extracaldera Volcanism}

Volcanism postdating the Yellowstone Caldera also has occurred in areas outside the caldera but within or near the boundaries of Yellowstone National Park. The individual eruptive products of this extracaldera volcanism are generally smaller in volume than most of those within the caldera but span nearly the same range of time as the intracaldera lavas (table 1). Both rhyolites and basalts occur among these extracaldera lavas. They erupted in three areas, including the following: (1) the southern part of the Norris-Mammoth corridor north of the caldera margin, (2) northwest of the caldera, and (3) near the southern boundary of Yellowstone National Park. Rhyolites of two distinct types of the Plateau Rhyolite erupted north of the caldera along the seismically and hydrothermally active Norris-Mammoth tectonic corridor. The Obsidian Creek Member is more porphyritic than the other Plateau Rhyolites, whereas the Roaring Mountain Member includes aphyric to very sparsely porphyritic rhyolites (Christiansen, 2001).

\section{Obsidian Creek Member}

The rhyolitic units of the Obsidian Creek Member (table 1) petrographically resemble the Scaup Lake flow of the Upper Basin Member (containing abundant quartz, sanidine, and plagioclase phenocrysts) and conformably overlie the Lava Creek Tuff (Christiansen, 2001). Rhyolitic domes form most of the Obsidian Creek Member; these include the Paintpot Hill, Gibbon Hill, The Landmark, Appolinaris Spring, and Willow Park domes.

Of note are the unique comingled rhyolite-basalt rocks in the Grizzly Lake, Gardner River, Crystal Spring, and Appolinaris Spring mixed-magma complexes outside the Yellowstone Caldera and along the Norris-Mammoth corridor (Fenner, 1938, 1944; Pritchard and others, 2013; Morgavi and others, 2016). Mixing textures preserved in these rocks include mafic enclaves, larger mafic pillows, complexly intertwined emulsion rocks that often include intermediate magma from mixing, and net-veined rocks formed by invasion of rhyolitic liquids into mafic enclaves (Pritchard and others, 2013). Pritchard and others (2013) also provide neodymium (Nd) and strontium ( $\mathrm{Sr}$ ) isotopic evidence of cryptic exchange between the basalt and rhyolite magmas, which suggests minor hybridization of basaltic melts before eruption.

\section{Roaring Mountain Member}

The Roaring Mountain Member includes a few small rhyolite lavas that either completely lack phenocrysts or have only sparse small crystals. Units of this member have a range of ages (table 1) from the Cougar Creek Dome at $0.358 \pm 0.002 \mathrm{Ma}$ (Nastanski, 2005; Christiansen and others, 2007) to the Gibbon River flow at $0.118 \pm 0.010 \mathrm{Ma}$, and the Crystal Spring flow at $0.080 \pm 0.002$ $\mathrm{Ma}$ (Obradovich, 1992). The paucity of phenocrysts in flows of the Roaring Mountain Member may signify high pre-eruptive $\mathrm{H}_{2} \mathrm{O}$ content or high magmatic temperatures.

\section{Present-Day Magmatic System and Crustal Structure}

The underground structure of the Yellowstone magmatic system has been a topic of research for many years. Smith and others (1974) and Eaton and others (1975) used data from a variety of geophysical techniques (gravity, magnetics, and teleseismic P-wave residuals) to infer the presence of shallow magma in the crust. Subsequent seismic tomographic studies provide further constraints on the loci of magma at depth.

The first seismic studies to find evidence of decreased seismic velocities beneath the Yellowstone Caldera used controlled-source data recorded with a 150-station array during the 1978 Yellowstone-Snake River Plain seismic experiment (Schilly and others, 1982; Smith and others, 1982; Lehman and others, 1982). These early studies found evidence for a major low-velocity body at depths of $\sim 3$ to $9 \mathrm{~km}$, with a decrease in velocity of at least 10 percent below the northeast part of the Yellowstone Plateau. Low P-wave velocities beneath the caldera were interpreted to represent a zone of high temperature associated with a partial melt and (or) large steam-water volumes.

These previous controlled-source studies paved the way for later tomographic studies that were able to image an extended body of low P-wave velocity of around -5 to -10 percent at depths of 6 to $16 \mathrm{~km}$, which was interpreted to be crystallizing magma beneath the Yellowstone Caldera. Benz and Smith (1984) showed two zones of unusually low velocities in the northeast and the southwest part of the caldera. Miller and Smith (1999) found a caldera-wide 15 percent decrease in P-wave velocities compared to the surrounding area at depths of 6 to $12 \mathrm{~km}$. In addition, they found a smaller but more pronounced low-velocity zone that underlies the northeast caldera rim from depths less than $2 \mathrm{~km}$ and explained this by the presence of a saturated fluid (gas or gas/liquid) filling fractures, and possibly the presence of hydrothermally altered volume of rock (Miller and Smith, 1999). A local earthquake tomographic study by Husen, Smith, and Waite (2004) confirmed the existence of a low P-wave velocity body beneath the Yellowstone Caldera at depths greater than $8 \mathrm{~km}$, possibly representing hot, crystallizing magma.

The two most recent tomographic studies of the Yellowstone magmatic system have used additional data and newer tomographic methods to bring the Yellowstone magmatic plumbing system "into focus." Farrell and others (2014a) used 4,520 local earthquakes and more than 48,000 travel-time observations from 1984 to 2011 to image the Yellowstone upper-crustal magma reservoir. Results reveal a low P-wave velocity body below the Yellowstone Caldera from depths from 5 to $16 \mathrm{~km}$. In addition, the low velocity body extends $\sim 15 \mathrm{~km}$ northeast of the caldera, although at shallower depths ( $\leq 4 \mathrm{~km}$ ). Farrell and others (2014a) interpreted the lowvelocity body to be the Yellowstone upper-crustal rhyolitic magma reservoir with 5 to 15 percent melt (fig. 9).

Most recently, Huang and others (2015) used both local earthquakes and teleseismic earthquakes to image the crustal magma system. Results show not only the upper-crustal magma reservoir at depths of 5 to $16 \mathrm{~km}$ below the Yellowstone Caldera, but also an additional lower-crustal basaltic magma reservoir at 

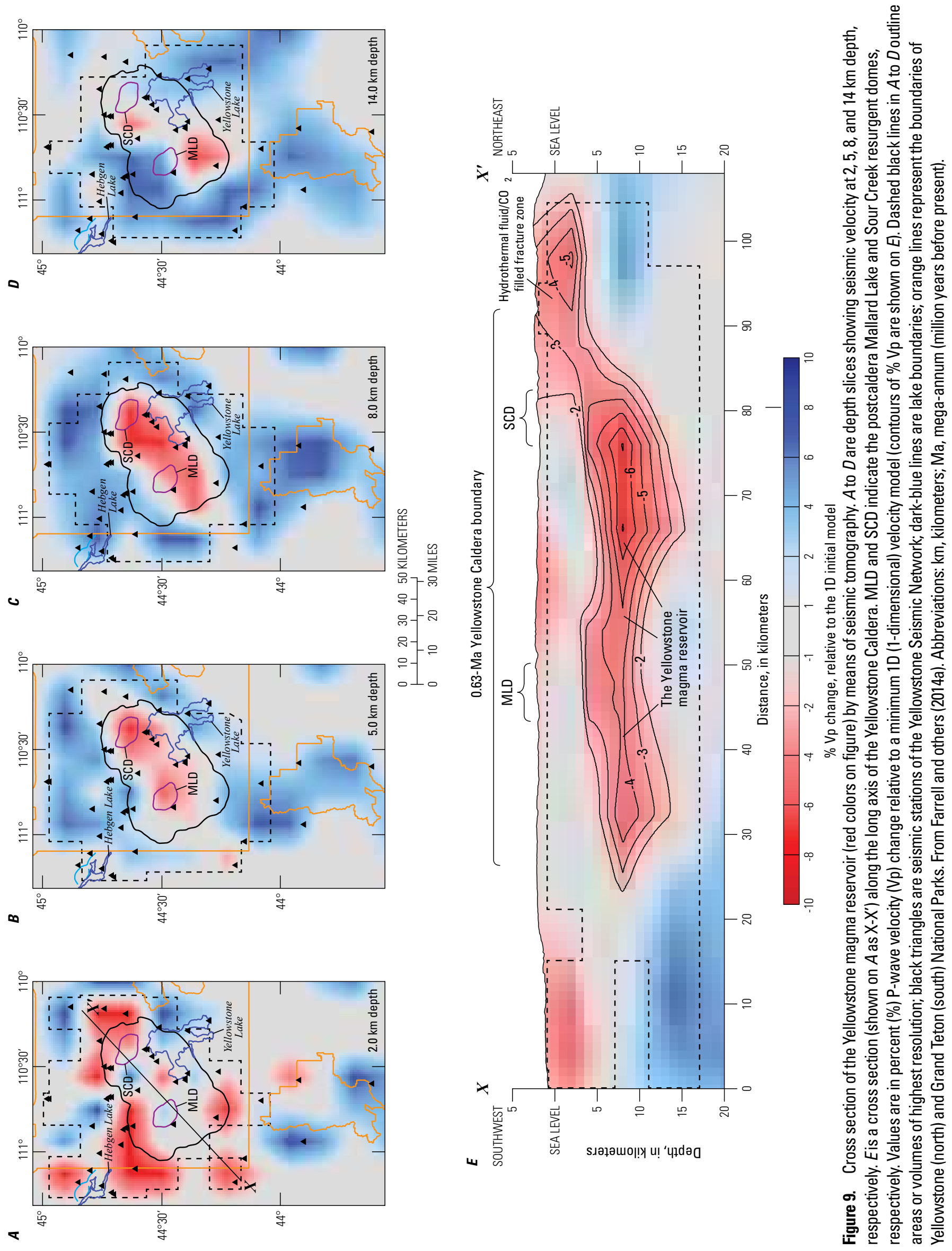
depths of 20 to $>40 \mathrm{~km}$, as shown schematically in fig. 3. This lower-crustal magma reservoir is $\sim 4.5$ times the size of the uppercrustal magma reservoir and provides a key connection between the mantle plume and the upper-crustal magma reservoir.

Indeed, the presence of magma in the lower crust makes sense from geological and geochemical constraints, even if the melt/crystal ratio is low ( $\sim 2$ percent melt), as inferred by Huang and others (2015). Isotopic and mass balance constraints require that the silicic magma erupted at Yellowstone is neither a pure crustal melt nor a product of simple crystal fractionation of mantle-derived basalt. Considerable hybridization must continually occur within the lower crust to generate high-silica rhyolite (Doe and others, 1982; Hildreth, 1991; Christiansen, 2001; Hughes and McCurry, 2002; Leeman and others, 2008). Moreover, the considerable flux of mantle-derived $\mathrm{CO}_{2}$ measured at the surface (45,000 tons per day; Werner and Brantley, 2003), if steady state, requires transit of $\mathrm{CO}_{2}$ through any silicic magma reservoir present in the upper crust (Lowenstern and Hurwitz, 2008). Given the inferred location of magma in the upper crust, and the high temperatures required to keep such magma partly molten, it seems necessary that some magma must extend throughout the middle to lower crust in dikes, sills, and other more complex reservoirs (fig. 3). The lower-crustal magma complex is most likely basaltic in composition.

\section{Glacial History}

Pleistocene alpine glaciation played a major role in shaping the landscape of Yellowstone and Grand Teton National Parks and surrounding environments, an area known as the Greater Yellowstone Geoecosystem (Good and Pierce, 1996; Pierce and others, 2007). During the past 160,000 years, the Yellowstone area was the center of the largest alpine glacial icecap in the western United States (Pierce, 2004).

The intensity and characteristics of glacial events in the Yellowstone area are closely tied to crustal dynamics associated with local volcanic and tectonic activity. Specifically, uplift related to the hot spot created an ideal situation for glacial ice accumulation, as shown by the Yellowstone geoid anomaly (Miller and Smith, 1999). The Yellowstone Plateau rises more than $1 \mathrm{~km}$ above the 90- to 100-km-wide topographic trough of the eastern Snake River Plain, where storms from the Pacific Northwest are channeled to the northeast. Once storm systems hit the orographic high of the Plateau, precipitation increases dramatically (fig. 10) (Pierce and others, 2007). The altitude increases from about $1,375 \mathrm{~m}$ on the eastern Snake River Plain to about 2,600 $\mathrm{m}$ on the Yellowstone Plateau (fig. 10) and produces a strong orographic effect resulting in about 180 centimeters $(\mathrm{cm})$ of precipitation per year on the Yellowstone Plateau as compared with $30 \mathrm{~cm}$ on the

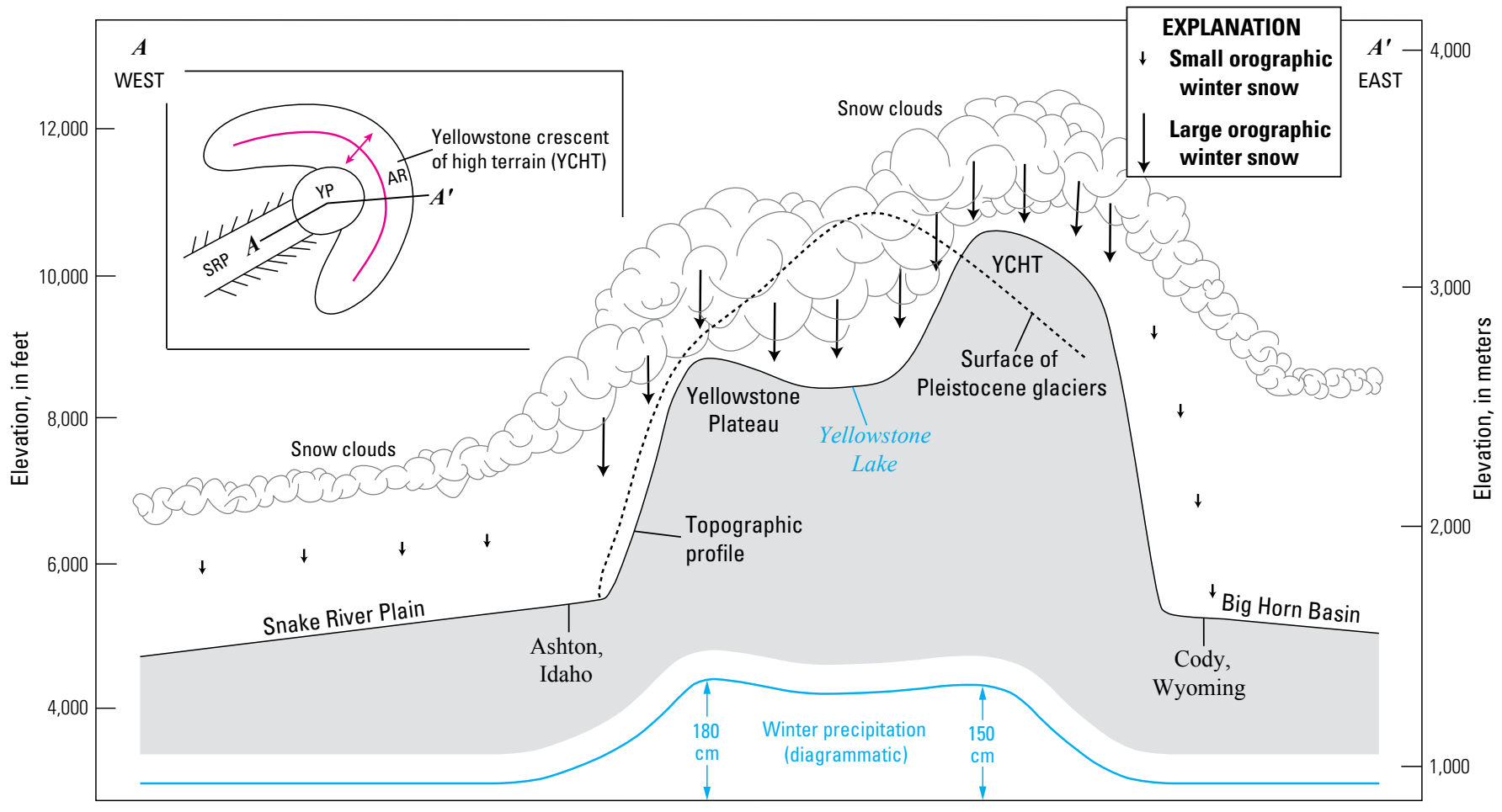

Figure 10. Diagram illustrating the orographic effect of the Yellowstone Plateau (YP) and the Yellowstone crescent of high terrain (YCHT) on precipitation (snowfall) in the region of the Snake River Plain (SRP) and Yellowstone Plateau. Regional west-to-east-moving weather systems are channeled northeastward along the Snake River Plain to the Yellowstone Plateau and continue northeast to the Absaroka Range (AR). The inset shows a schematic map view of the locations of the SRP, YP, YCHT (axis highlighted in red) and the AR. The short, angled lines along the SRP represent the trough-like topography present along the track of the hot spot, which channels moisture-laden storms. The cross section depicted in the main figure is shown in inset as A-A'. Orographic uplift causes considerably increased precipitation at Yellowstone relative to the surrounding lowlands. This contributes to the current wet conditions on the Yellowstone Plateau and to the intensity and extent of past glaciations. The blue line shows that the approximate winter precipitation at the Yellowstone Plateau and the YCHT is approximately 180 and $150 \mathrm{~cm}$, respectively. Modified from Pierce and others (2007). 
eastern Snake River Plain. During glacial events, the ice buildup atop the Yellowstone Plateau rose to an altitude of about 3,350 m, increasing the orographic effect and creating a self-perpetuating glacial accumulation system (Pierce and others, 2007).

Glaciation in the greater Yellowstone area includes the Bull Lake and Pinedale glaciations that correlate with the latest Illinoian and Wisconsin glaciations in the mid-continent, respectively (U.S. Geological Survey, 1972a; Pierce, 1979; Licciardi and Pierce, 2008; Pierce and others, 2014). Bull Lake terminal moraines in northern Yellowstone are preserved in the West Yellowstone area. Bull Lake glaciation is about 140,000 years old based on obsidian hydration studies (Pierce and others, 1976). More recently, cosmogenic ${ }^{10} \mathrm{Be}$ dating of boulders deposited at the southern limit of the Bull Lake ice advance south of Jackson, Wyoming, (fig. 11) yields a mean age of $0.136 \pm 0.0013 \mathrm{Ma}$ and oldest ages of 0.151 to $0.157 \mathrm{Ma}$ (ages shown in thousands of years before present [ka] in figure 11). These ages correlate with the Bull Lake of West Yellowstone and with the type section of Bull Lake of the Wind River Range (Licciardi and Pierce, 2008). Bull Lake ice advanced into the West Yellowstone basin largely through lowlands later filled by the 0.114-Ma West Yellowstone rhyolite lava flow (Christiansen and others, 2007).

Pinedale glaciation represents the last major glacial event in the greater Yellowstone area. North of the park, Pinedale glaciers extended beyond the Bull Lake terminal moraines (fig. 11), largely because lava flows emplaced between 0.075 and $0.148 \mathrm{Ma}$ in the western part of the Yellowstone Plateau diverted ice flow to the north rather than northwest. Cosmogenic exposure ages from boulders (fig. 11) in Pinedale till in the Paradise Valley of the Yellowstone River north of Gardiner (fig. 1, inset) give ages between 0.0161 and $0.0175 \mathrm{Ma}$ for final retreat of Pinedale ice (Licciardi and Pierce, 2008), which are generally consistent with previous hydration rind ages (Pierce and others, 1976; Pierce, 1979).

Ice from the Gallatin Range, the Yellowstone Plateau, the Washburn Range, the Beartooth Uplift, and the upper Lamar drainage (fig. 11) coalesced to form the northern Yellowstone glacier (Pierce, 1979; Pierce and others, 2014). The icecap on the Yellowstone Plateau near what is now Yellowstone Lake (near YP in fig. 11) reached an altitude of 11,000 feet (ft) (about 3,350 m), indicating over a kilometer of ice thickness over the central basin of Yellowstone Lake. Ice flowed outward from the Yellowstone Lake drainage into adjacent basins where ice levels were lower, including south into the Jackson area (fig. 11).

During stages of Pinedale recession, glacial ice from smaller tributary valleys receded first and, in some cases, lakes formed where the main glacier blocked the tributary valleys. Along the Yellowstone River in the Gardiner area, longitudinal and mid-channel bars and flood-ripped fronts of alluvial fans indicate the occurrence of at least two separate floods, with waters $60 \mathrm{~m}$ and $45 \mathrm{~m}$ deep (Pierce and others, 2014). Two additional, younger floods down valley of the Yellowstone River resulted from (1) breach of a landslide dam north of Gardiner and (2) from a lake in the Grand Canyon of the Yellowstone (Pierce, 1979).

\section{Thermal Areas and Hydrothermal Activity}

High heat flow over a relatively large area, high precipitation rates, and active seismicity and deformation on the Yellowstone Plateau drive the hydrothermal systems at Yellowstone (figs. 3, 12), making it one of the largest on Earth. The large magmatic reservoir at depth, with temperatures in excess of $800{ }^{\circ} \mathrm{C}$, heats the surrounding rocks, resulting in average heat flow values about 30 times greater at Yellowstone than surrounding areas in the northern Rocky Mountains (Fournier, 1989). Meteoric fluids percolate deep into the heated crust above the Yellowstone magma chamber and evolve into fluids that are altered by water-rock interaction during hydrothermal alteration in the subsurface. The hydrothermal fluids entrain and later degas magmatic and crustal volatiles $\left(\mathrm{CO}_{2}, \mathrm{H}_{2} \mathrm{~S}, \mathrm{H}_{2}, \mathrm{CH}_{4}, \mathrm{Ar}\right.$, and $\left.\mathrm{He}\right)$, are strongly affected by boiling and mixing upon ascent, and ultimately deposit impressive quantities of sinter or travertine near and at the surface (Fournier, 1989; Hurwitz and Lowenstern, 2014).

\section{Types of Geothermal Fluids}

Three primary water types dominate the chemistry of thermal features at Yellowstone National Park (figs. 12-14; table 3). Alkaline-chloride waters disharge as springs and geysers, depositing silica-sinter terraces and mounds. Acidsulfate fluids are found in steam-heated geothermal areas as fumaroles (steam vents), frying pans (where gases vent through shallow steam condensate pools) and mud pots (where acidic fluids attack local wall rock producing clay-rich muds). Travertine depositing calcium carbonate waters saturated in aragonite or calcite form travertine terraces such as those at Mammoth Hot Springs. Mixed travertine and sinter deposits are found in a few small areas in the park.

\section{Alkaline-Chloride Waters}

Alkaline-chloride waters make up the majority of thermal fluids discharged from the Upper, Midway, and Lower Geyser Basins, West Thumb, Heart Lake, Shoshone, Glen Africa, and Norris Geyser Basins, among others (figs. 12-14; table 3). Their $\mathrm{pH}$ values typically range from 6.7 to 9.6 (neutral $\mathrm{pH}$ at $94{ }^{\circ} \mathrm{C}$ is about 6.2) and they are silica-saturated and create abundant terraces, platforms, and mounds of opaline silica (opal-A) that decorate the geyser basins (Allen and Day, 1935; Braunstein and Lowe, 2001; Guidry and Chafetz, 2002). The dominant anion is $\mathrm{Cl}^{-}$(fig. 13), which is charge-balanced primarily by $\mathrm{Na}^{+}$ (Fournier, Christiansen, and others, 1994). Such waters constitute the dominant fluids present in the subsurface beneath the primary geyser basins within the park, as confirmed by scientific drilling in the late 1960s (White and others, 1975, 1988). Total discharge of alkaline-chloride waters has been used to estimate flux of thermal waters through a combination of streamgaging and frequent chemical analyses of $\mathrm{Cl}^{-}$in river discharge (Fournier and others, 1976; Friedman and Norton, 1990, 2000, 2007). Currently, about 50,000 tons per year of chloride emerge from Yellowstone, 


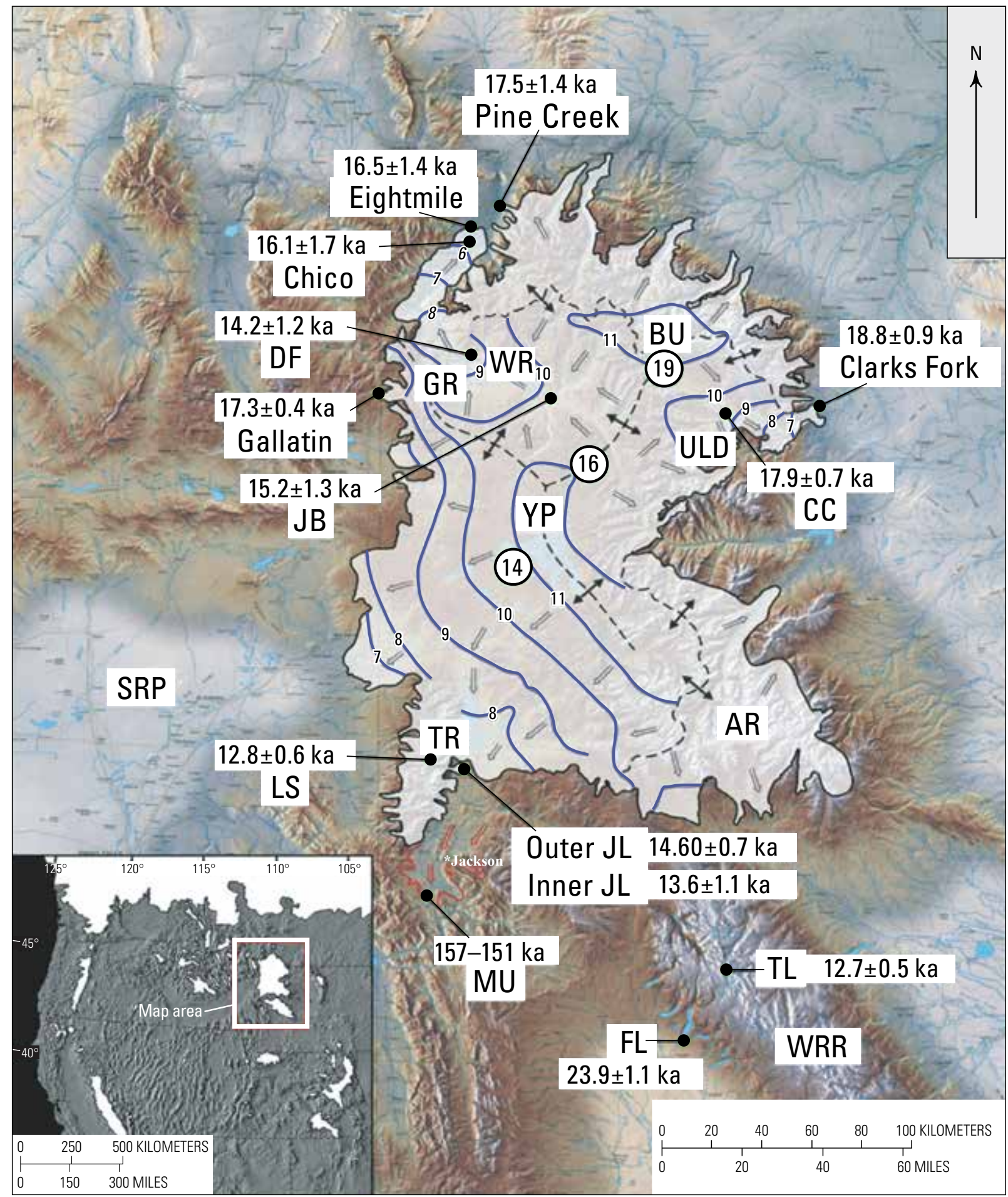

Figure 11. Summary map of recessional moraine ages of the northern Yellowstone glacier from cosmogenic ${ }^{10} \mathrm{Be}$ dating of glacial boulders (black dots show locations). Blue lines depict maximum Pinedale ice surface elevation contours in thousands of feet. Red line and arrows indicate Bull Lake ice limit and flow direction in Jackson Hole. Encircled numbers are ages in thousands of years before present (ka) that indicate the southwest migration of the center of the Yellowstone glacial system through time. Dashed black lines represent highest elevation of ice surface; double black arrows on dashed black lines represent direction of ice movement; single arrows represent local ice flow directions. Glacier outlines in the inset location map of the western United States are from Pierce (2004). Figure from Licciardi and Pierce (2008). Abbreviations: AR, Absaroka Range; Be, beryllium; BU, Beartooth Uplift; CC, Crandall Creek; DF, Deckard Flats; FL, Fremont Lake; GR, Gallatin Range; JB, Junction Butte; JL, Jenny Lake; LS, Lake Solitude; MU, Munger ice limit; SRP, Snake River Plain; TL, Titcomb Lakes; TR, Teton Range; ULD, upper Lamar drainage; WR, Washburn Range; WRR, Wind River Range; YP, Yellowstone Plateau. 


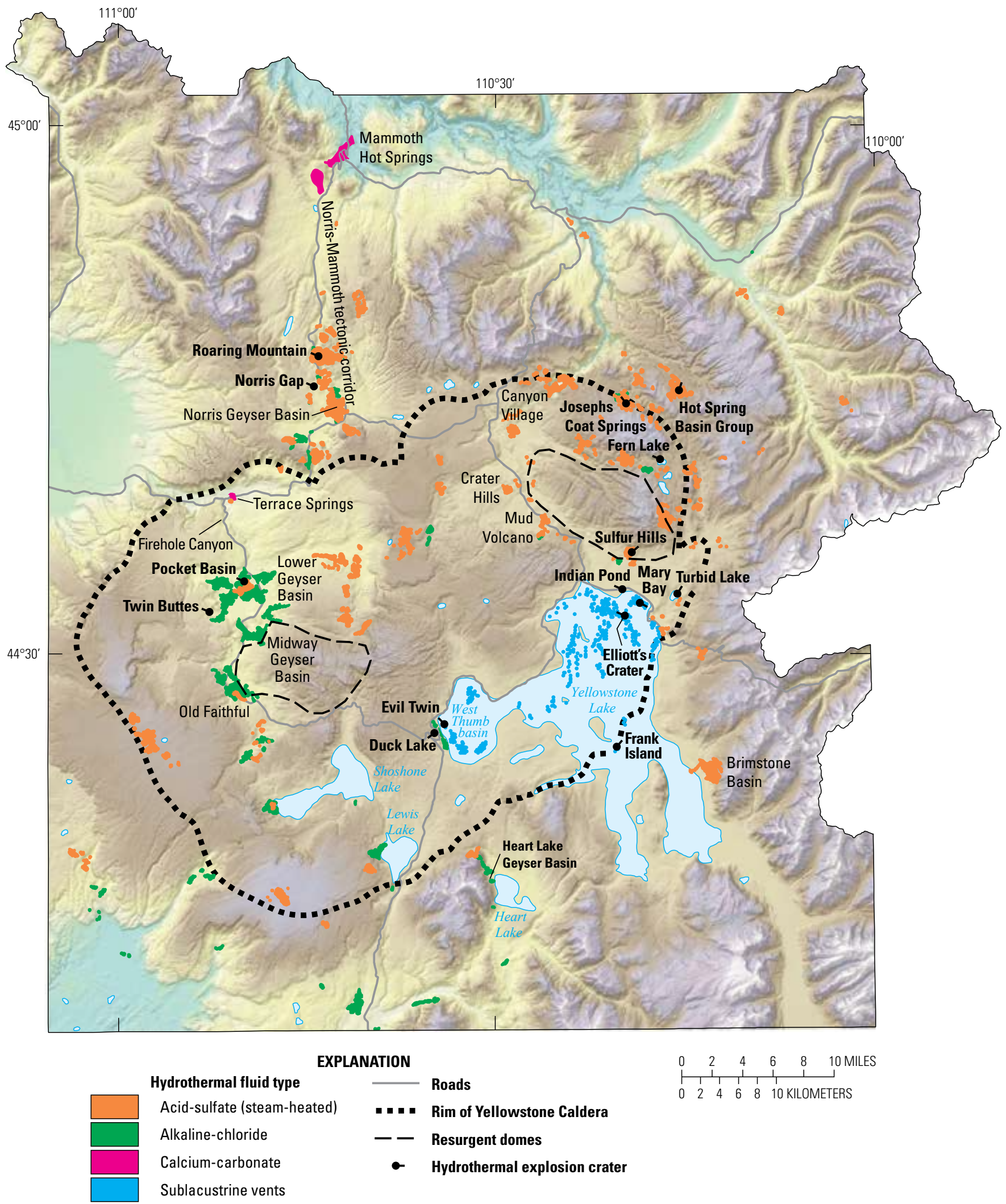

Figure 12. Map showing the location of active thermal areas categorized by hydrothermal fluid type and the location of large hydrothermal explosion craters (location shown with black dot and leader) with associated breccia deposits in Yellowstone National Park (locations from Morgan and others, 2009). Figure modified from Lowenstern and Hurwitz (2008). 


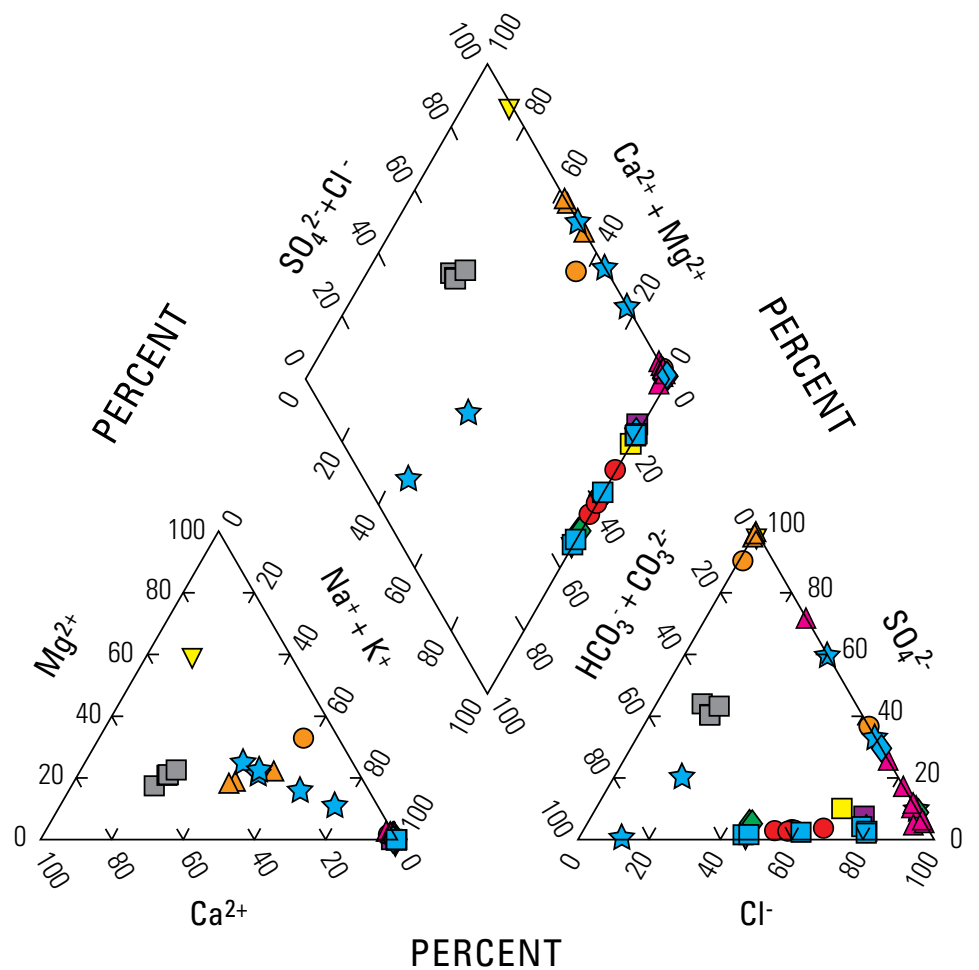

\section{EXPLANATION}

Alkaline-chloride waters

Beryl Spring

$\nabla \quad$ Excelsior Geyser Crater

$\diamond \quad$ Lonestar Geyser

- Lower Geyser Basin

$\Delta \quad$ Norris Geyser Basin

$\square \quad$ Sevenmile Hole

$\square \quad$ Upper Geyser Basin

$\diamond \quad$ West Thumb Geyser Basin

Yellowstone Lake vents

Acid-sulfate waters

$\nabla \quad$ Brimstone Basin

$\diamond \quad$ Crater Hills

$\triangle \quad$ Mud Volcano

○ Washburn

Calcium carbonate waters Mammoth Hot Springs

Figure 13. Piper diagram showing chemical variations in Yellowstone hydrothermal fluids. Major anion and cation components of the waters are compared based on relative concentrations in milliequivalents. Results show that most fluids are the alkaline-chloride type, which plot near the $\mathrm{Na}^{+}+\mathrm{K}^{+}$apex, along the $\mathrm{Cl}$ side of the anion triangle, and are dominated by $\mathrm{HCO}_{3}{ }^{-}$ $+\mathrm{CO}_{3}{ }^{2}$ from $\mathrm{CO}_{2}$ gas. Acid-sulfate waters derived from steam-dominant systems have the lowest $\mathrm{Cl}$ concentration, contain abundant $\mathrm{SO}_{4}{ }^{2-}$ from sulfide oxidation, are $\mathrm{CO}_{2}$ rich, and contain substantial proportions of $\mathrm{Ca}^{2+}$ and $\mathrm{Mg}^{2+}$ due to alteration of silicate minerals by acid attack. Mammoth Hot Spring fluids, the major travertine depositing system in Yellowstone National Park, are dominated by $\mathrm{Ca}^{2+}, \mathrm{Mg}^{2+}, \mathrm{HCO}_{3}$, and $\mathrm{SO}_{4}{ }_{4}^{2-}$ due to reaction with Mesozoic limestones in the subsurface. Sample data and sources are shown in table 3 . Abbreviations: $\mathrm{Ca}^{2+}$, calcium; $\mathrm{Cl}$, chloride; $\mathrm{CO}_{2}$, carbon dioxide; $\mathrm{CO}_{3}^{2-}$, carbonate; $\mathrm{HCO}_{3}$, bicarbonate; $\mathrm{K}^{+}$, potassium; $\mathrm{Mg}^{2+}$, magnesium; $\mathrm{Na}^{+}$, sodium; $\mathrm{SO}_{4}{ }^{2-}$, sulfate.

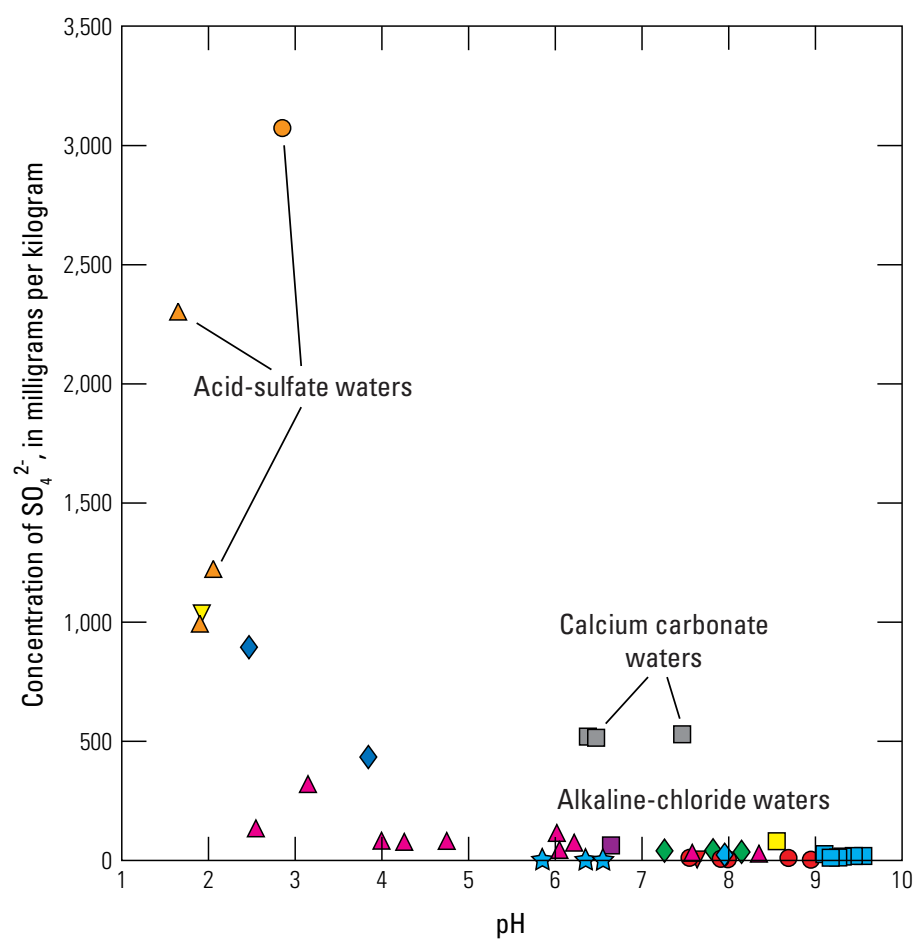

\section{EXPLANATION}

Alkaline-chloride waters

$\square \quad$ Beryl Spring

$\nabla$ Excelsior Geyser Crater

$\diamond \quad$ Lonestar Geyser

- Lower Geyser Basin

$\Delta \quad$ Norris Geyser Basin

$\square \quad$ Sevenmile Hole

$\square \quad$ Upper Geyser Basin

$\diamond \quad$ West Thumb Geyser Basin

Yellowstone Lake vents

Acid-sulfate waters

$\nabla \quad$ Brimstone Basin

$\diamond \quad$ Crater Hills

$\triangle$ Mud Volcano

○ Washburn Hot Springs

Calcium carbonate waters

$\square \quad$ Mammoth Hot Springs
Figure 14. Diagram illustrating the relationship between $\mathrm{pH}$ and dissolved sulfate $\left(\mathrm{SO}_{4}{ }^{2-}\right)$ in Yellowstone hydrothermal fluids, showing exponential increase in $\mathrm{SO}_{4}{ }_{4}$ - concentration related to oxidation of $\mathrm{H}_{2} \mathrm{~S}$ in acid-sulfate (steam-heated) systems in strongly acidic fluids. Hydrothermal fluid sample data and sources are provided in table 3. Abbreviations: $\mathrm{H}_{2} \mathrm{~S}$, hydrogen sulfide; $\mathrm{pH}$, negative $\log _{10}$ of hydrogen ion. 


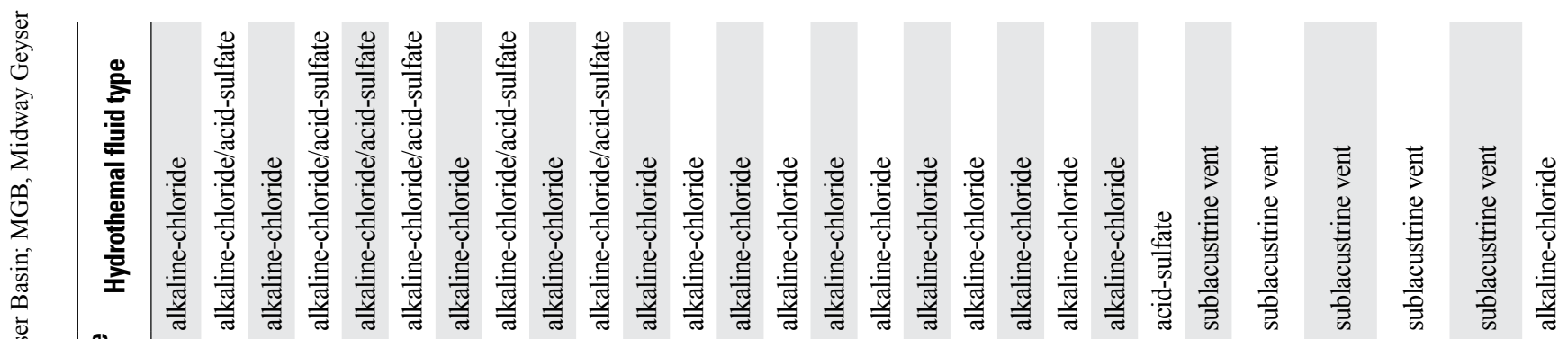

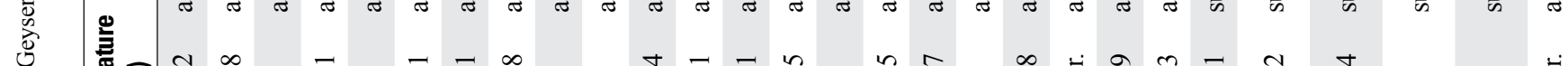

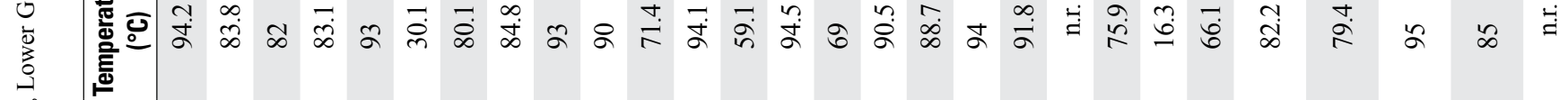

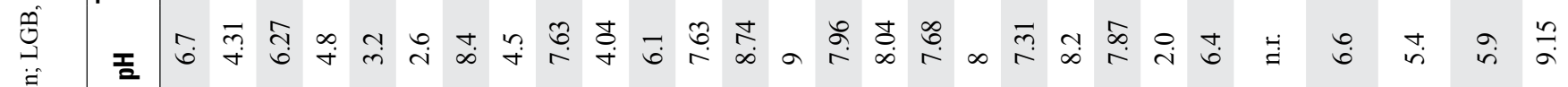

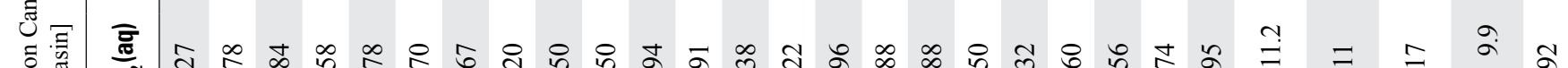
is

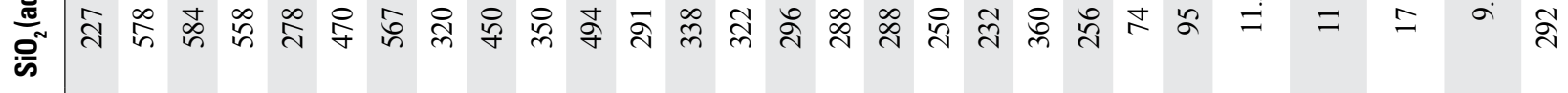

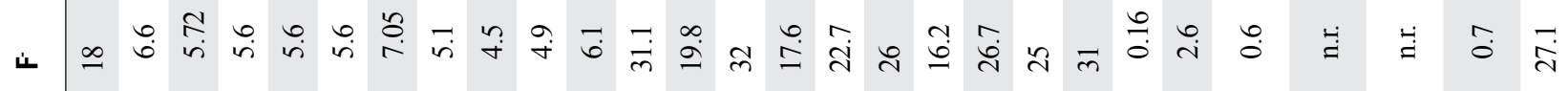

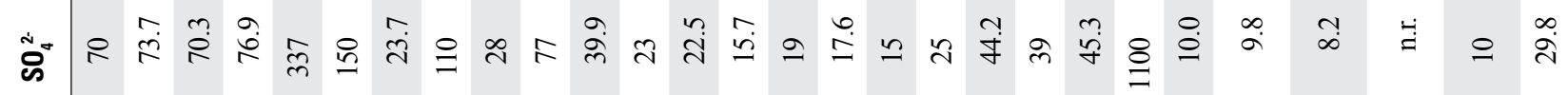

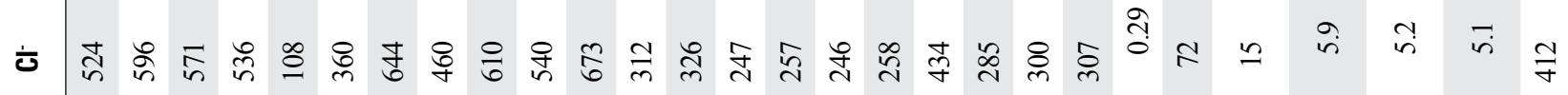

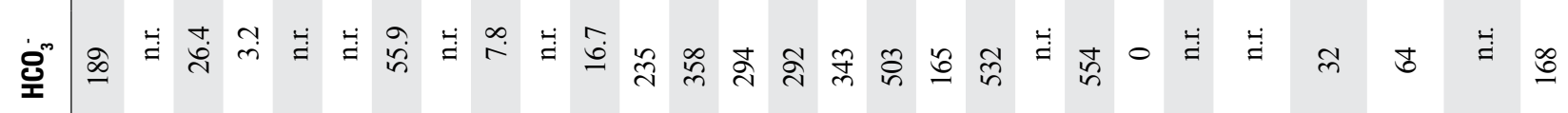

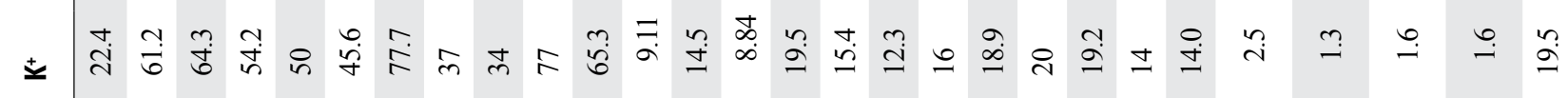

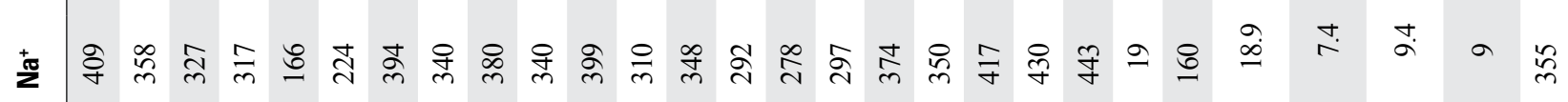

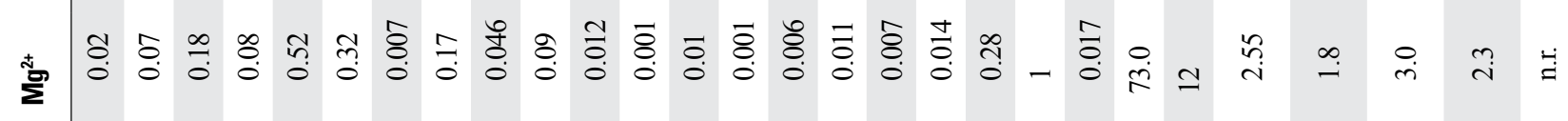

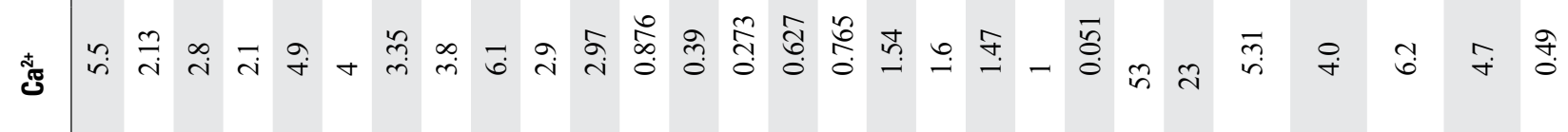




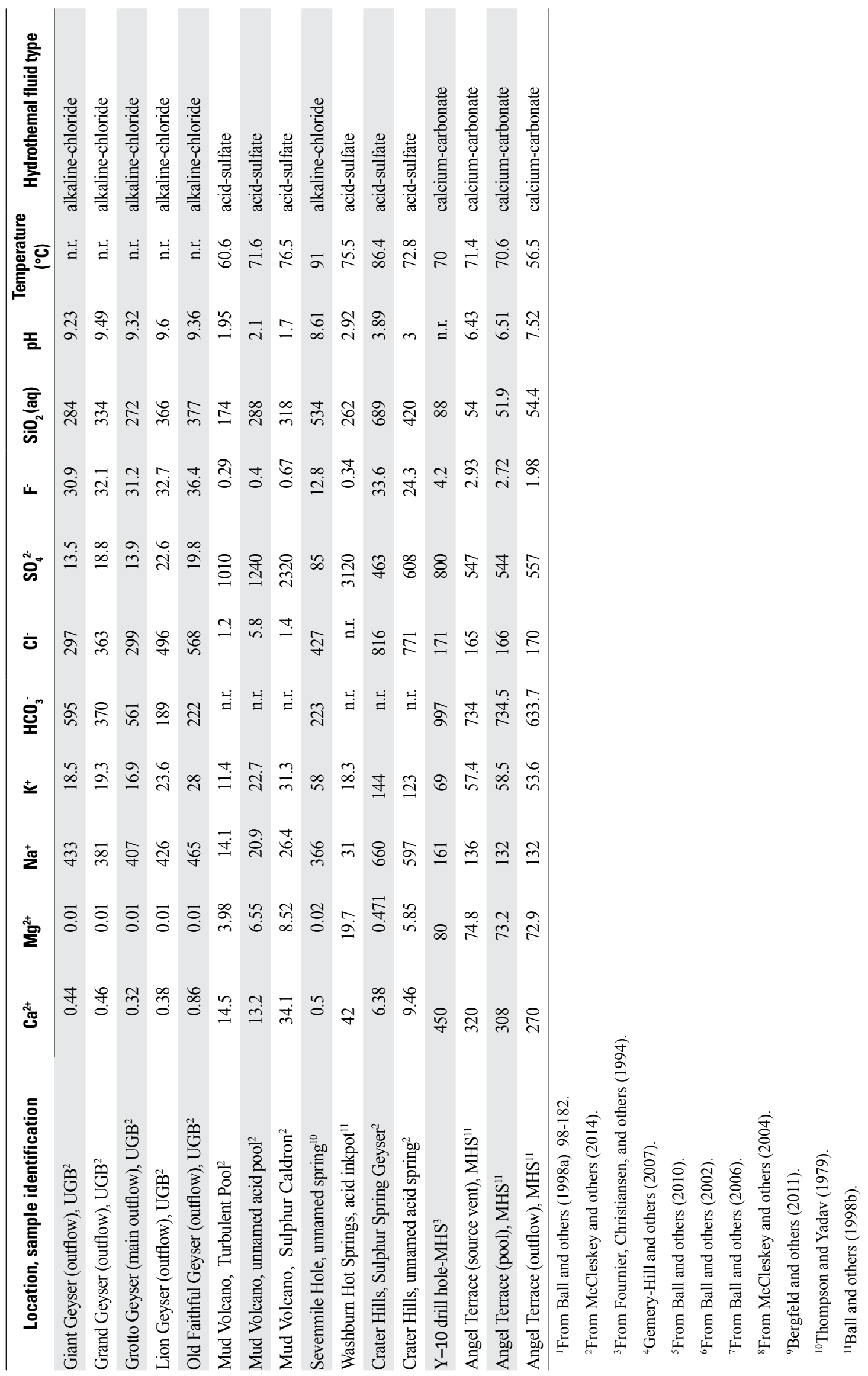


corresponding to $\sim 4,000$ liters per second of deep parent fluid (Hurwitz and others, 2007).

Several authors (Fournier and others, 1976; Fournier, 1989; Rye and Truesdell, 2007; Truesdell and others, 1977) have provided evidence that all of Yellowstone's alkalinechloride waters were related to a parent 340 to $370{ }^{\circ} \mathrm{C}$ fluid, rich in dissolved $\mathrm{CO}_{2}$ and $\mathrm{H}_{2} \mathrm{~S}$, and with $\sim 400 \mathrm{ppm} \mathrm{Cl}$, and delta deuterium $(\delta \mathrm{D})$ of -149 per mil. The low $\delta \mathrm{D}$ of deepseated waters compared with most local meteoric waters has variously led workers to conclude that the thermal waters were recharged at high elevations in the Gallatin and Absaroka Ranges, or during colder climate periods such as the Little Ice Age (Kharaka and others, 2002; Rye and Truesdell, 2007). A recent detailed summary of this topic can be found in Hurwitz and Lowenstern (2014).

Boiling and mixing with local groundwaters during ascent of hydrothermal fluids (fig. 15) causes most of the variation in chemistry of hot springs (Fournier, Christiansen, and others, 1994; Fournier, 1989; Shanks and others, 2005; Balistrieri and others, 2007). Water-rock interaction with volcanic and other rocks at geothermal temperatures of 100 to $300{ }^{\circ} \mathrm{C}$ is also an important process, producing alkalinechloride waters that are enriched in ${ }^{18} \mathrm{O}$ and trace elements (As, $\mathrm{Hg}, \mathrm{Sb}, \mathrm{W}$, and $\mathrm{Mo}$ ) relative to local meteoric water (Balistrieri and others, 2007; Fournier, 1989; Kharaka and others, 2002; Shanks and others, 2005, 2007; Rye and Truesdell, 2007; Hurwitz and Lowenstern, 2014).

\section{Acid-Sulfate Waters}

Acid-sulfate waters are low in $\mathrm{pH}(<5$ and range as low as 0.7 ; figs. 13,14 ; table 3 ), low in $\mathrm{Cl}^{-}$, and elevated in $\mathrm{SO}_{4}^{2-}$ and cations leached from host rocks $\left(\mathrm{Na}^{+}, \mathrm{K}^{+}, \mathrm{Mg}^{2+}, \mathrm{Ca}^{2+}\right)$. The waters are usually interpreted as forming due to condensation of geothermal steam into perched thermal pools, mud pots, and shallow groundwater (White and others 1971; Nordstrom and others, 2009). Consistent with that interpretation, acidsulfate waters are most commonly found atop the lava plateaus and in the eastern parts of Yellowstone where alkaline-chloride fluids are less common. In most cases, the steam and gas are interpreted to emerge through deep alkaline-chloride water. At the Heart Lake Geyser Basin, Lowenstern and others (2012) reported that acid-sulfate fluids were only present near the topographically higher Witch Creek drainage, whereas alkaline-chloride waters discharge at lower elevations. Elsewhere (Hot Springs Basin, Smokejumper Hot Springs, Highland Hot Springs), alkaline-chloride waters are absent, or are inferred to reside solely in the deep subsurface.

Oxidation reactions in acid-sulfate waters, mediated by thermophile lifeforms, can convert the abundant $\mathrm{H}_{2} \mathrm{~S}$ to
Figure 15. Generalized schematic diagram of mixing, boiling, degassing, and geochemical reaction processes in the subsurface of the Upper Geyser Basin affecting hydrothermal fluids. Similar processes occur in the subsurface of many of Yellowstone's thermal basins. From Fournier, Christiansen, and others (1994). Abbreviations: ${ }^{\circ} \mathrm{C}$, degrees Celsius; $\mathrm{CH}_{4}$, methane; $\mathrm{Cl}^{\text {}, ~ c h l o r i d e ; ~}$ $\mathrm{CO}$, carbon monoxide; $\mathrm{CO}_{2}$, carbon dioxide; $\mathrm{H}_{2}$, hydrogen; $\mathrm{H}_{2} \mathrm{O}$, water; $\mathrm{H}_{2} \mathrm{~S}$, hydrogen sulfide; $\mathrm{HCO}_{3}$, bicarbonate; $\mathrm{NaCl}$, sodium chloride; $\mathrm{NaHCO}_{3}$, sodium bicarbonate; $\mathrm{O}_{2}$, oxygen; $\approx$ approximately equal; $\gg>$, much greater than.

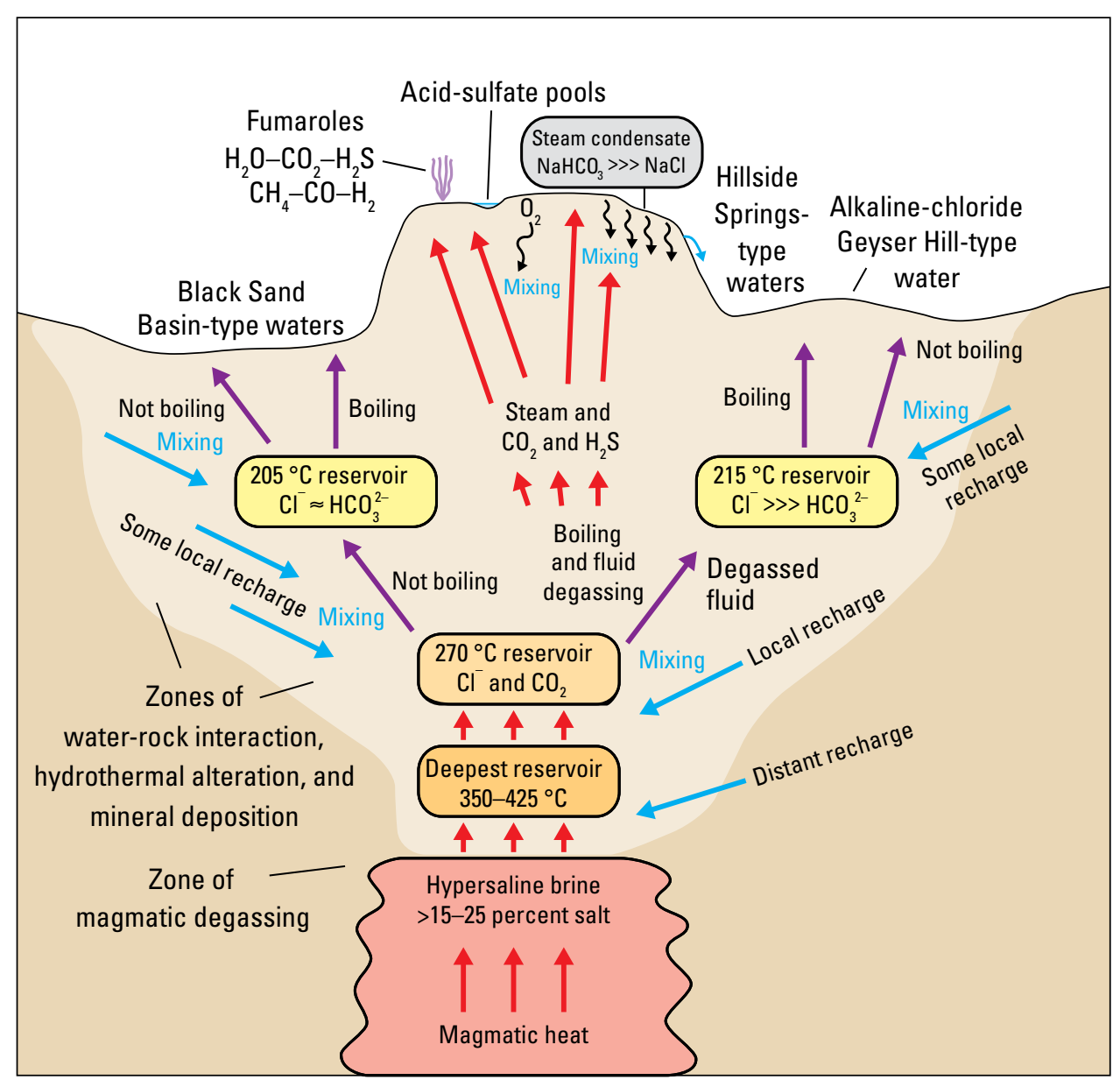


soluble sulfuric acid, which actively reacts with the local rhyolitic rocks. Various thermophilic acid-tolerant bacteria and archaea utilize dissolved $\mathrm{HS}^{-}$and native sulfur to form $\mathrm{SO}_{4}{ }^{2-}$ and $\mathrm{H}^{+}$(Brock, 1978). Dissolved sulfide also can be oxidized by $\mathrm{Fe}^{3+}$ in water. The end result of numerous sulfur-oxidizing reactions is the creation of acidic fluid that reacts with the rock to form abundant clays. In acid-sulfate waters, chemical variations show that $\mathrm{SO}_{4}{ }^{2-}$ increases exponentially due to oxidation of dissolved sulfide or elemental sulfur, producing very low pH (strongly acidic) waters (fig. 14).

\section{Calcium-Carbonate Waters}

The chemical composition of water at Mammoth Hot Springs (table 3 ) is carbonate-rich and saturated in calcium carbonate (travertine). The $\mathrm{pH}$ of the discharged waters is typically about 6 , but increases rapidly to about 8 as $\mathrm{CO}_{2}$ is degassed (fig. 14) at or near the surface (Sorey and Colvard, 1997; Kharaka and others, 2000). Compared with alkalinechloride waters, thermal waters at Mammoth Hot Springs are relatively rich in $\mathrm{Ca}^{2+}, \mathrm{Mg}^{2+}, \mathrm{HCO}_{3}^{-}$, and $\mathrm{SO}_{4}^{2-}$ (fig. 13, table 3). Water temperatures are $\leq 73{ }^{\circ} \mathrm{C}$, and even inferred subsurface reservoir temperatures are much lower than the alkaline-chloride systems. Fouke and others (2000) argue that the chemical variation of waters in Mammoth Hot Springs pools and drainages is almost entirely related to inorganic precipitation reactions, though the formation of travertine is accelerated by the physical presence of thermophilic bacteria, mainly cyanobacteria (Kandianis and others, 2008).

Calcium-carbonate waters of the Mammoth terraces, responsible for precipitation of immense travertine deposits, are inferred to be due to interaction of thermal water with subsurface limestones at a relatively low reservoir temperature of $73{ }^{\circ} \mathrm{C}$ (Bargar, 1978; Fournier, Christiansen, and others, 1994). In contrast, other more dilute (and with higher $\mathrm{Na} / \mathrm{Ca}$ ) travertine-forming waters occur at Hillside Springs (Upper Geyser Basin) and Firehole Lake area springs, which are interpreted to be mixtures of steam condensate and heated meteoric water, all equilibrated at low temperatures, resulting in saturation with calcite rather than silica sinter (Fournier, Christiansen, and others, 1994). Another travertine-forming spring (saturated in both travertine and silica sinter) is Terrace Springs, which occurs along the Yellowstone Caldera wall and is thought to be a mixture of deep alkaline-chloride water and cold meteoric water (Fournier and Truesdell, 1974).

\section{Gas and Steam}

Fumaroles and gas bubbles from all thermal areas share similar chemistries; the dominant species is $\mathrm{H}_{2} \mathrm{O}$ unless the thermal feature is well below the boiling point of $\mathrm{H}_{2} \mathrm{O}$ and gas directly effervesces or traverses the pool. Gas contents range from 0.01 percent (relative to $\mathrm{H}_{2} \mathrm{O}$ ) to a maximum of 15 percent at Mud Volcano (Bergfeld and others, 2011; Lowenstern and others, 2015). In virtually all samples, the dominant non- $\mathrm{H}_{2} \mathrm{O}$ gas species is $\mathrm{CO}_{2}$, which makes up
$>90$ percent of the gas. Other important gas species are $\mathrm{H}_{2} \mathrm{~S}, \mathrm{H}_{2}, \mathrm{~N}_{2}$, and $\mathrm{CH}_{4}$. The noble gases $\mathrm{He}, \mathrm{Ne}$, and $\mathrm{Ar}$ are present and their isotopes provide important evidence of meteoric water recharge and degassing of old crustal rocks (Lowenstern and others, 2015). Organic species $\left(\mathrm{CH}_{4}, \mathrm{C}_{2} \mathrm{H}_{6}\right)$ are more common in the eastern part of Yellowstone, where Tertiary volcaniclastic rocks and Cretaceous sediments are common in the subsurface. Oil seeps and oil-bearing springs have long been known in Yellowstone National Park (Love and Good, 1970; Clifton and others, 1990).

Magmatic volatiles are important components in Yellowstone hydrothermal systems. Magmatic volatile compositions are known from studies of fumaroles (Lowenstern and Hurwitz, 2008; Bergfeld and others, 2011; Chiodini and others, 2012), which show that the gases are dominated by $\mathrm{CO}_{2}-\mathrm{H}_{2} \mathrm{~S}-\mathrm{CH}_{4}-\mathrm{CO}-\mathrm{H}_{2}$. Lowenstern and Hurwitz (2008) noted that the high $\mathrm{CO}_{2}$ and $\mathrm{H}_{2} \mathrm{~S}$ (relative to $\mathrm{Cl}^{-}$and $\mathrm{F}^{-}$) are consistent with deep degassing of underplated basaltic magma related to the Yellowstone mantle plume (fig. 3). Werner and Brantley (2003) estimated a total flux of $\mathrm{CO}_{2}$ in Yellowstone National Park of 45,000 tons per day, comparable with total $\mathrm{CO}_{2}$ flux from the Hawaiian hot spot. ${ }^{3} \mathrm{He} /{ }^{4} \mathrm{He}$ ratios in Yellowstone hot springs and fumaroles range from less than 2.5 to about 17 (fig. 16); the higher values often are interpreted as strong geochemical evidence for deep contributions from the underlying mantle plume (Kennedy and others, 1985). In some locations, especially outside the caldera, extensive metamorphism of Archean crust in the deep subsurface releases ${ }^{4} \mathrm{He}$ that dilutes the signature of deep-seated ${ }^{3} \mathrm{He}$ (Lowenstern and others, 2014).

\section{Connection Between Geography and Thermal Area Type}

The preponderance of alkaline-chloride thermal areas is found at the edges of postcaldera rhyolite flows, or in low-elevation basins between flows (Morgan and Shanks, 2005). A fluid flow model developed for sublacustrine conditions predicts that fully cooled rhyolitic lava flows exert a fundamental influence on subsurface hydrology and subsequent hydrothermal vent locations (Morgan and others; 2003) (fig. 17). We assume similar processes apply to subaerial lavas. Thermal fluids that ascend, some along tectonically controlled fractures, beneath lava flows are directed laterally away from thicker, more impermeable segments of the flow through the brecciated base of the flow toward the fractured flow margin (Morgan and Shanks, 2005). Thermal areas have migrated over time. Following burial by lavas, thermal waters must have migrated laterally to discharge at the present-day lava margins (Morgan and Shanks, 2005; Hurwitz and Lowenstern, 2014). Other zones of weakness in lava flows include former eruptive volcanic vent areas (for example, Smokejumper Hot Springs) and fractures associated with the active structural deformation of 

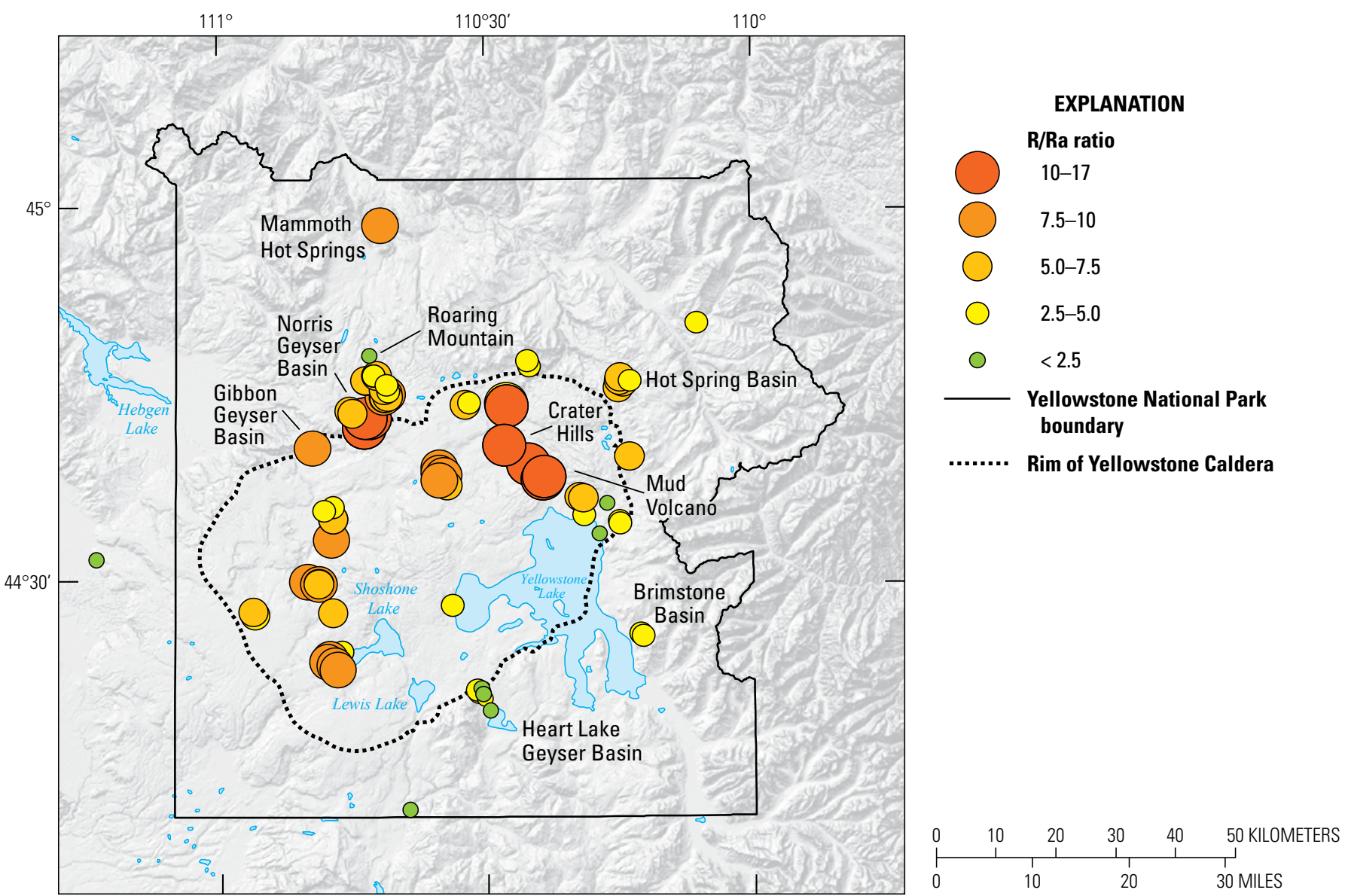

Figure 16. Map showing helium isotope ratios $\left({ }^{3} \mathrm{He} /{ }^{4} \mathrm{He}\right.$ relative to atmosphere) from hot springs and fumaroles in Yellowstone National Park, coded by symbol size and color. Highest values are located in the eastern part of the Yellowstone Caldera. Low values are most common outside the caldera. From Lowenstern and others (2014). Abbreviations: $\mathrm{He}$, helium; $\mathrm{R},{ }^{3} \mathrm{He} /{ }^{4} \mathrm{He}$ ratio of the sample; Ra, present day atmospheric ratio of ${ }^{3} \mathrm{He} /{ }^{4} \mathrm{He}$.

Figure 17. Diagram showing the factors related to hydrothermal fluid flow beneath lava flows. $A$, Schematic diagram showing physical features of a rhyolitic lava flow after emplacement. $B$, Two-dimensional fluid flow model of a simple glaciolacustrine sedimentary aquifer (no capping lava flow), which results in low flow velocities, recharge at the surface, and lateral flow out of both ends of the model aquifer. $C$, Fluid flow model now with a fully cooled rhyolitic lava flow overlying the sedimentary aquifer. The addition of a 190-m-thick fractured crystalline lava flow strongly focuses the upward limb of an intense convection cell. In this model, fluid temperatures reach $110^{\circ} \mathrm{C}$, and flow velocities are as high as 150 millimeters per year (mm/yr). D, Map of northern Yellowstone Lake showing location of vents (yellow dots) adjacent to the high-relief edges of lava flows. E, Fluid flow model that includes a fractured basal breccia unit beneath a lava flow with low permeability. Flow vectors (arrows) indicate strong upflow under the lava flow, with maximum subsurface temperatures of $\sim 140^{\circ} \mathrm{C}$ and flow rates up to $100 \mathrm{~mm} / \mathrm{yr}$. Modified from Morgan and others (2003). Abbreviations: ${ }^{\circ} \mathrm{C}$, degrees Celsius; ROV, remotely operative vehicle. 
$\boldsymbol{A}$

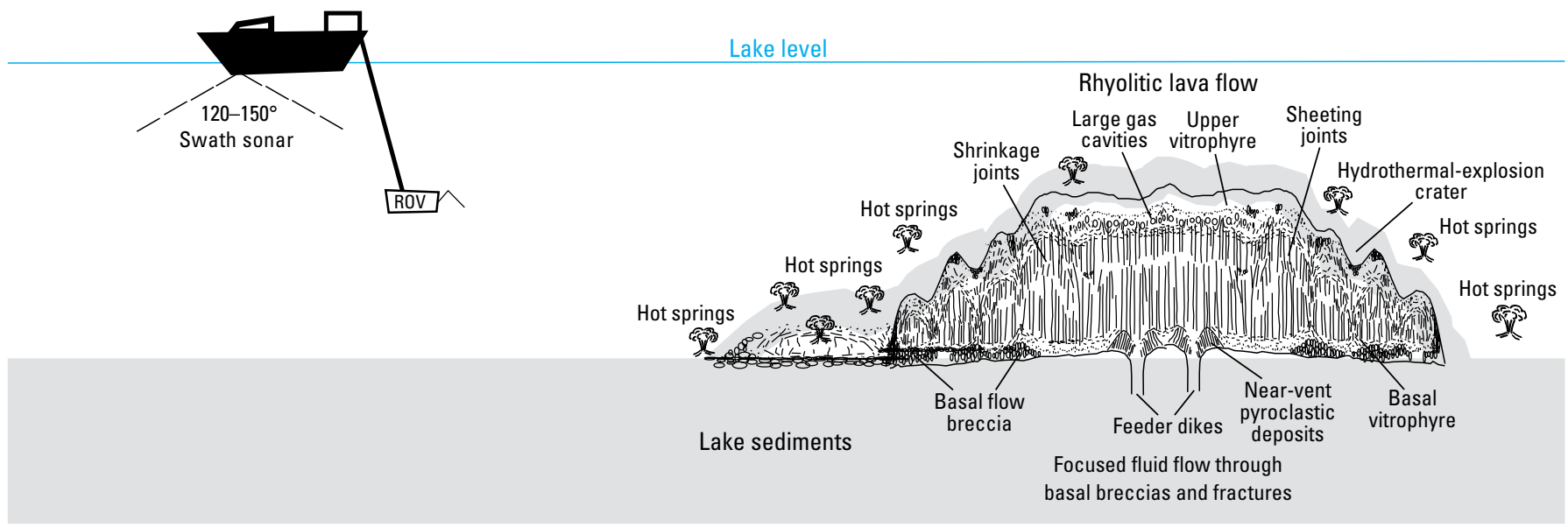

B

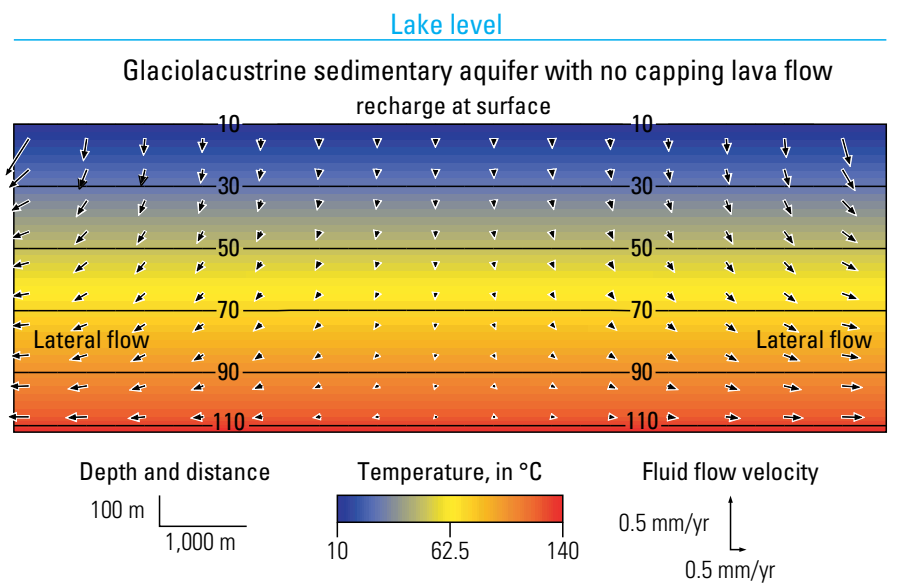

D

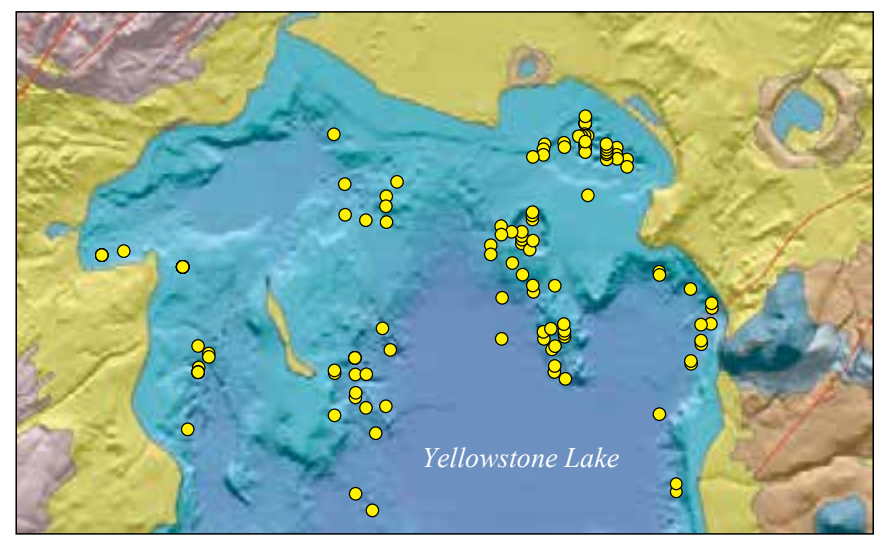

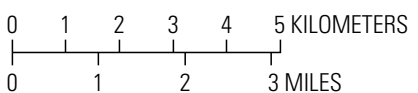

C

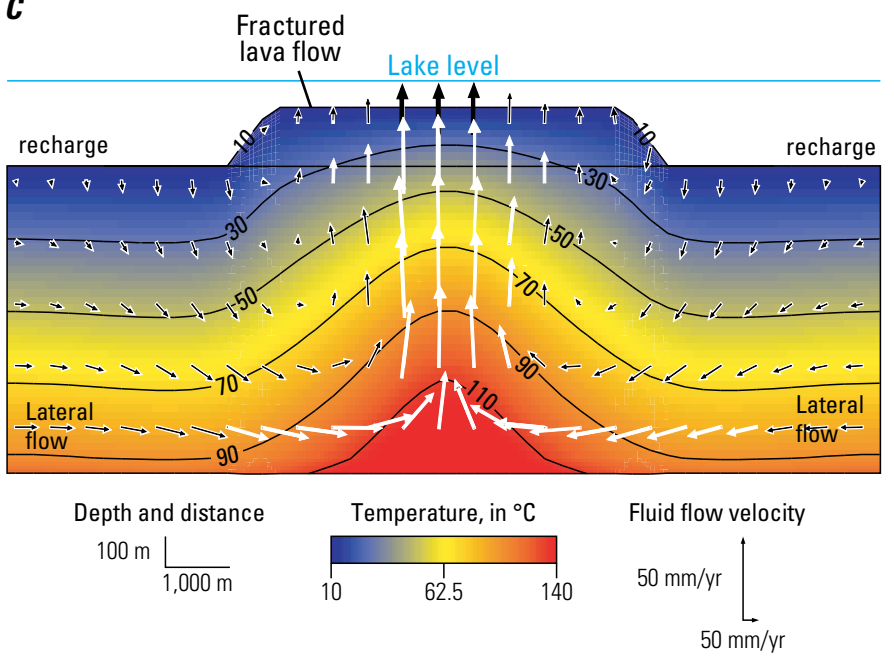

$\boldsymbol{E}$

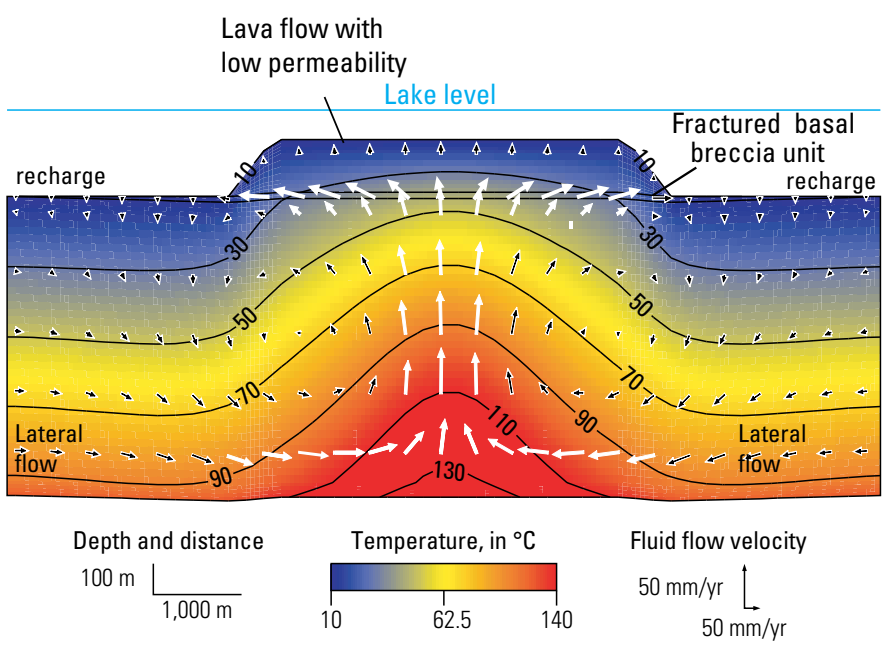


the Yellowstone Caldera (for example, Bridge Bay) (Morgan and others, 2009).

Differences in the amount of gas bubbles seen rising through pools at different locations are due to variations in spring location and their tie to conduits or fractures that create gas vents (fig. 18). These variations also can produce steam-heated vents immediately adjacent to pools of alkalinechloride hydrothermal fluid (fig. 15).

Norris Geyser Basin is located outside and just north of the northwest margin of the Yellowstone Caldera along the Norris-Mammoth tectonic corridor. Here, the Lava Creek Tuff is the host rock and is fractured from seismic activity related to the Norris-Mammoth tectonic zone and deformation of the caldera. Fractures transmit waters and related gases directly to the surface (Jaworowski and others, 2006). Subsurface mixing, boiling, and infiltration provide an environment ideal for creation of mixed acid-chloride fluids that are a hybrid of alkaline-chloride and acid-sulfate fluids (figs. 13, 14). Such mixed fluids are relatively common at Norris Geyser Basin but are relatively rare at other thermal basins.

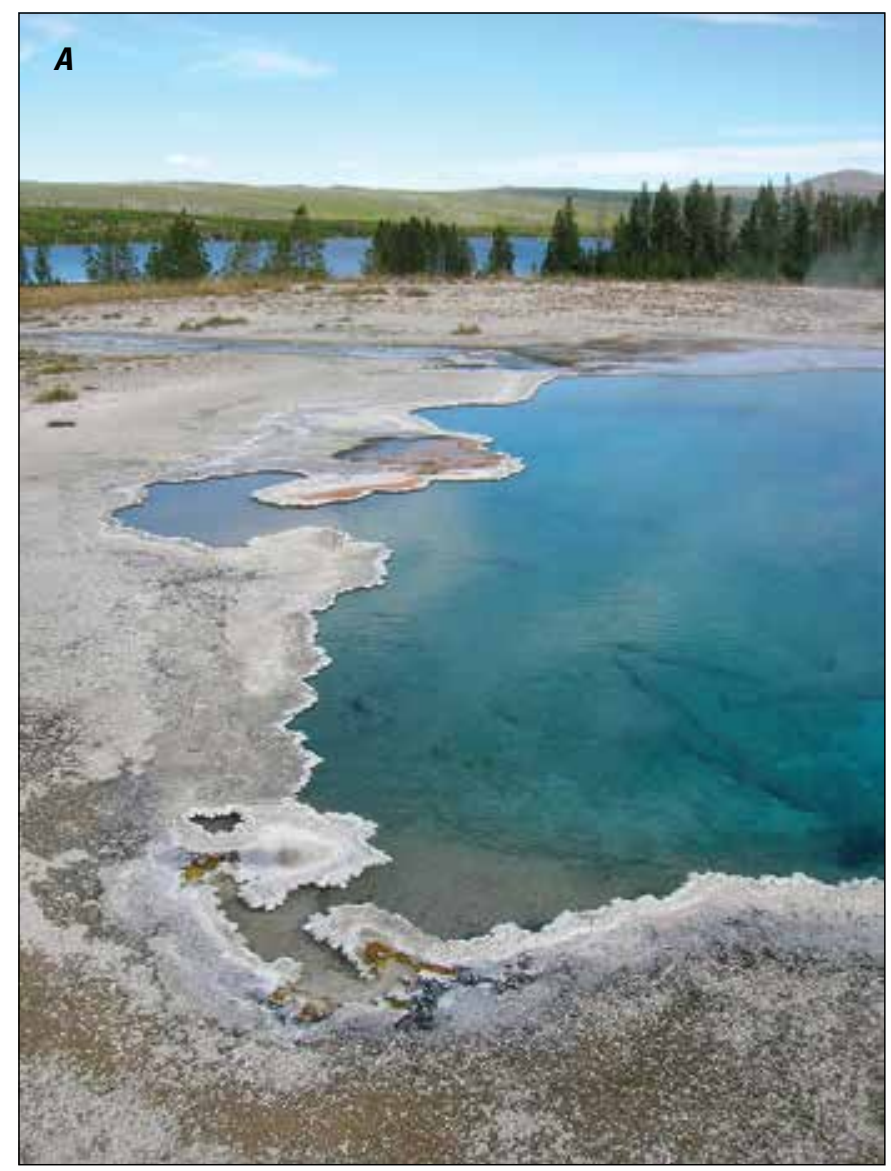

\section{Types of Thermal Features}

An extraordinary variety of hot springs, fumaroles, geysers, mud pots, sinter and travertine deposits, hydrothermal explosion craters, and hydrothermally altered rocks is reflected in the more than 10,000 hydrothermal features present at Yellowstone National Park (Allen and Day, 1935; Fournier, 1989; Schreier, 1992;

Ann Rodman, unpub. data, Yellowstone National Park, 2007). The thermal waters, gases, and mineral deposits host microbial communities that affect water chemistry, types and morphologies of deposits, coloration of thermal pools, and represent a spectacular part of the life-cycle (Sheehan and others, 2005).

\section{Fumaroles}

Fumaroles are steam and gas vents that often produce loud hissing, growling, or thumping sounds. They can contain deepseated gases from magmatic degassing that are dominated by $\mathrm{CO}_{2}$, with lesser amounts of $\mathrm{H}_{2} \mathrm{~S}, \mathrm{H}_{2}, \mathrm{CH}_{4}, \mathrm{Ar}$, and $\mathrm{He}$ (Bergfeld and others, 2011; Lowenstern and others, 2015). They also may simply be due to shallow subsurface boiling of geothermal waters,

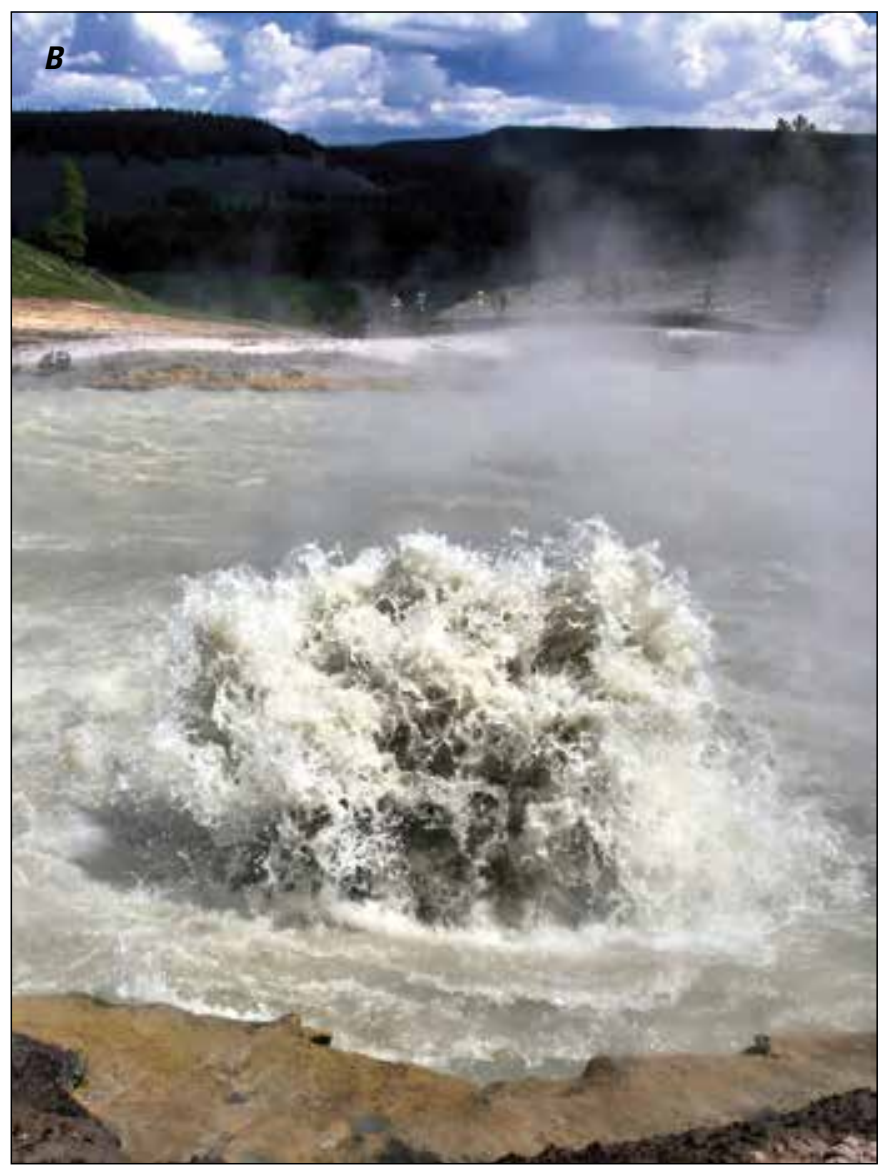

Figure 18. Photographs showing the wide range of gas discharge from thermal pools at Yellowstone. $A$, Columbia Spring (alkalinechloride type water) at Heart Lake Geyser Basin has negligible gas flux but moderate flow of near-boiling-temperature $\mathrm{H}_{2} 0$. $B$, Churning Cauldron at Mud Volcano is a pool of sub-boiling acid water with little outflow, but has a gas discharge of $\sim 0.24$ kilograms per second carbon dioxide $\left(\mathrm{CO}_{2}\right)$. Photograph $A$ from Lowenstern and others (2015). Photograph $B$ from Wikimedia Commons (https://commons. wikimedia.org/wiki/File:Churning_Caldron.jpg, accessed June 28, 2017). 
creating emissions with high steam-to-gas ratio (Lowenstern and others, 2015).

\section{Mud Pots}

Mud pots are drowned fumaroles. They are acidic features usually related to steam and gases that separate and rise from hot fluids at depth (White and others, 1971; Hurwitz and Lowenstern, 2014). Above the water table, $\mathrm{H}_{2} \mathrm{~S}$ in these fluids reacts with $\mathrm{O}_{2}$ to produce native sulfur or $\mathrm{H}_{2} \mathrm{SO}_{4}$, which results in very acidic fluids that vigorously attack and alter host rocks in close proximity. The effects of $\mathrm{H}_{2} \mathrm{~S}$ oxidation are illustrated by equations (1) and (2) and the observed results from geochemical analysis of fluids (see acidsulfate waters in fig. 14):

$$
\begin{gathered}
\mathrm{H}_{2} \mathrm{~S}+2 \mathrm{O}_{2}=\mathrm{SO}_{4}^{2-}+2 \mathrm{H}^{+} \\
\mathrm{S}^{\circ} \text { (elemental sulfur) }+1.5 \mathrm{O}_{2}+\mathrm{H}_{2} \mathrm{O}=\mathrm{SO}_{4}^{2-}+2 \mathrm{H}^{+}
\end{gathered}
$$

Some thermophilic microorganisms use the oxidation of $\mathrm{S}^{\circ}$ or $\mathrm{H}_{2} \mathrm{~S}$ as energy sources, leading to even more acidity. Hot acidic fluids break down rock into clay minerals (kaolinite, smectite, illite) and hydrous sulfate minerals (alunite, jarosite). In some cases, iron liberated from rock alteration reacts with $\mathrm{H}_{2} \mathrm{~S}$ in the fluids to form fine-grained black-to-grey pyrite that colors the mud black and often creates an oily-looking surface sheen. Conversely, oxidation of iron in the muds or fluids creates a variety of pink, orange, red, or brown muds. Steam and gas escape through the wet mud, causing mud pots to bubble and spatter. Mud pot liquidity and activity vary with the seasons and precipitation, and also depend on the amount of steam condensation. Hot springs with clear liquid pools in steam-driven acid-sulfate areas form from steam condensate a nd therefore, like the mud pots, have strongly acidic fluids ( $\mathrm{pH}$ from 3 to 0.7 ) that are sulfate-rich and chloridepoor (fig. 13, 14). Frying pan vents occur in steam-heated areas where hot ground appears to boil and spatter like grease in a frying pan due to intense bubbling of gas and steam through a thin layer of hot water.

\section{Hot Springs}

Hot springs are the most common hydrothermal features in the park. Beginning as precipitation (rain or snow), the hot spring waters are heated at depth (to temperatures well above the surface boiling point) and rise through an open plumbing system back to the surface. Boiling occurs in high temperature fluids as they rise, often releasing steam and dissolved gases that vent separately as fumaroles. Convection in surface pools mixes waters while cooling, evaporation, overflow, and mineral precipitation take place in and around the hot springs. Acidsulfate or steam-heated fluids also form pools consisting of steam condensate (plus or minus admixed surface runoff) but do not build thick sinter terraces because silica is not effectively transported in steam (see Monument Geyser Basin section in Morgan and others, 2007b).
Hot spring pools occur in a variety of sizes and shapes, but many are roughly circular (typically 1 to $10 \mathrm{~m}$ in diameter) in area and roughly conical in three dimensions. They form due to a combination of chemical dissolution, collapse, and in some cases minor hydrothermal explosions (for example, Seismic Geyser) (Marler and White, 1975). Shanks and others $(2005,2007)$ have provided strong geochemical evidence that conical hydrothermal vent structures on the floor of Yellowstone Lake form by dissolution of silica from the lake sediments, but similar studies have not been completed on subaerial hot spring pools. Grand Prismatic Spring at Midway Geyser Basin is the largest example of this type of pool (105 $\mathrm{m}$ in diameter by $37 \mathrm{~m}$ deep).

Many hot springs in Yellowstone construct vent structures of siliceous sinter $\left(\mathrm{SiO}_{2}\right)$ or travertine $\left(\mathrm{CaCO}_{3}\right)$ in a fantastic variety of shapes ranging from horizontal terraces to small or large mounds to localized cones or spires deposited around vent conduits. Shapes of such vent edifices are a function of vent conduit geometry, rate and longevity of fluid venting, chemistry of fluids, rate of mineral deposition, and geological setting of the vent (subaerial versus pool versus lake bottom).

\section{Geysers}

Geysers require boiling water, a vent conduit with a constriction, and a subsurface cavity below the constriction. Hot fluids rise buoyantly into the conduit from subsurface reservoirs and fill the cavity (Bryan, 2008; Vandemeulebrouck and others, 2013). Constrictions above the cavity restrict water escape until boiling causes flashing to steam. Once steam is produced, pressure-release generates more steam and the geyser erupts until its reservoir is emptied (or partly emptied). Gases, including $\mathrm{CO}_{2}, \mathrm{~N}_{2}$, and Ar contribute to vapor pressure during the boiling process and can aid in inducing geyser eruptions (Hurwitz and others, 2016; Ladd and Ryan, 2016). Refilling begins following the eruption, leading eventually to the successive eruptions. At Old Faithful, a subsurface cavity that occurs as a side chamber about $20 \mathrm{~m}$ west-southwest from the geyser vent has been located by seismic studies of hydrothermal tremor due to boiling and cavitation (Vandemeulebrouck and others, 2013). The side cavity represents a recharge reservoir that acts as a "bubble trap" that fills and pressurizes. Prior to eruption, Old Faithful experiences harmonic oscillations in the level of fluid with amplitudes of about $1 \mathrm{~m}$ and a period of about 1 minute due to free oscillations of a column of liquid water in the conduit above a compressible steam-rich fluid region in the side cavity. Studies of Lone Star Geyser show a similar subsurface side chamber located 15 to 20 $\mathrm{m}$ northeast from the geyser vent (Vandemeulebrouck and others, 2014) and previous studies using video images show side cavities in four geysers in Geyser Valley, Kamchatka, Russia (Belousov and others, 2013). It appears that such geometries may be a common feature of eruptive geysers, but most geyser conduit and cavity geometries have not been studied in detail.

Different geysers erupt at different intervals (ranging from perpetual spouters to irregular, infrequent eruptions) with different water/steam ratios to different heights and diameters. Individual geysers have characteristic eruption intervals and eruption styles 
(spray, jet, fountain, spouter, etc.) that are related to differences in rates of hot water supply, size and configuration of underground caverns or reservoirs, conduit size and shape, and diameter of the constriction (Bryan, 2008). Yellowstone geysers occur in the hottest thermal basins, which characteristically have alkalinechloride fluids that deposit siliceous sinter due to cooling and evaporation at the surface. This commonly produces sinter fans or broad mound-like shapes; sinter deposits near geyser vents can have a broad variety of shapes including cones, pools, spires, and mounds. About 500 geysers are active in Yellowstone today (Bryan, 2008; Hurwitz and Lowenstern, 2014), more than exist for all other hydrothermal systems combined on Earth.

\section{Hydrothermal Explosions}

Hydrothermal explosions are violent and dramatic events resulting in the rapid ejection of boiling water, steam, mud, and rock fragments from source craters (Muffler and others, 1971; Browne and Lawless, 2001) that range from a few meters to more than $2 \mathrm{~km}$ in diameter. Explosion columns for the largest hydrothermal explosions are estimated to be about $1.9 \mathrm{~km}$ in height (Morgan and others, 2009). Associated breccia deposits are exposed as far as 3 to $4 \mathrm{~km}$ from the largest craters. Hydrothermal explosions occur in areas where shallow interconnected reservoirs of steam- and liquid-saturated fluids at temperatures close to the boiling curve underlie thermal fields. Sudden reduction in confining pressures causes fluids to flash to steam, resulting in significant fluid expansion, rock fragmentation, and debris ejection (Browne and Lawless, 2001; Morgan and others, 2009) (fig. 19). Hydrothemal explosion events comprise the most violent and extreme end-member of the fumarole-hot spring-geyser eruption spectrum.

Conditions leading to explosions in Yellowstone most likely involve the following primary processes: (1) high, focused heat flow where increases in boiling of thermal waters results in increased steam production as water ascends to the surface; (2) pervasive alteration of host rocks underlying hydrothermal systems; and (3) silica deposition due to cooling of hot silica-rich waters, resulting in clogging of pores and open fractures (Shanks and others, 2005). Decreased permeability and restriction of fluid flow can result in increased fluid pressure and increased likelihood of a hydrothermal explosion that excavates altered and fractured host rocks.

Hydrothermal explosion products in Yellowstone are identified only in postglacial deposits $(\leq 16-14 \mathrm{ka})$ (Pierce and others, 2014). At least 20 large (>100-m-diameter, up to 2.6-km-diameter), subaerial hydrothermal explosion craters have been identified within and along the margin of the Yellowstone Caldera and along the active Norris-Mammoth tectonic corridor (fig. 12). The scale of individual events at Yellowstone dwarfs similar-type features in geothermal areas elsewhere globally; many of the hydrothermal explosion craters here are in excess of $500 \mathrm{~m}$ diameter (fig. 20) (Morgan and others, 2009). The explosion craters are relatively shallow features ejecting only the upper several hundred meters of substrata. Studies of the large hydrothermal events in
Yellowstone indicate (1) none are associated directly with volcanic or intrusive activity; (2) the substrata was extensively hydrothermally altered prior to explosion, as reflected in the lithic clasts and comingled clay matrix forming the hydrothermal explosion breccia deposit; (3) lithic clasts in the explosion breccia show evidence of repeated fracturing, brecciation, and vein-filling, suggestive of a long-term hydrothermal system in place prior to explosion; and (4) several small prehistorical explosions have been triggered by seismic events.

The breccia deposits associated with these craters exhibit remarkable variability and are related to depth of explosion and subsurface stratigraphy. These deposits contain no juvenile material (molten prior to the explosion-triggering event) and show no evidence of concurrent volcanic eruptive activity (Morgan and others, 2009). Small historical hydrothermal explosion events sometimes have been documented in the park (Fournier and others, 1991; Marler and White, 1975), whereas others are noted but not described in sufficient detail to interpret the processes and triggering mechanisms. None of the large explosion events (Indian Pond, Mary Bay, Duck Lake, Pocket Basin, Turbid Lake, and several others on the floor of Yellowstone Lake; fig. 12) were witnessed and recorded; thus, uncertainty remains about precursor signals and processes leading up to an explosion.

Large explosions, which certainly are less destructive than catastrophic events such as caldera-forming eruptions and highseismic events, are still a significant hazard. The relative frequency of large hydrothermal explosions warrants monitoring of geothermal areas (Christiansen and others, 2007). Understanding precursors and potential triggers to explosions and the processes involved are factors necessary in anticipating their formation.

\section{Microorganisms Related to Thermal Features}

The Yellowstone Caldera contains the most numerous and diverse geothermal systems known on the continents, yielding an extensive array of unique high-temperature environments. Microorganisms in Yellowstone's thermal features include thermophilic bacteria, archaea, and viruses that make their homes in the hydrothermal waters of Yellowstone and often appear as brightly colored deposits around the margins of hot springs or thermal drainage channels. Thermophiles live at temperatures between 41 and $122^{\circ} \mathrm{C}\left(106\right.$ and $\left.252^{\circ} \mathrm{F}\right)$ (Sheehan and others, 2005; Inskeep and others, 2010) and many of these organisms utilize energy from chemical reactions rather than photosynthesis. More familiar microorganisms that rely on photosynthetic energy live on the fringes of the hot spring vent areas and throughout the park. Microorganisms that live in the highest temperature (hyperthermophiles, $\geq 80^{\circ} \mathrm{C}$ ), the most acidic, or the most alkaline environments are called extremophiles because they inhabit environments that are extreme for the survival of most life forms.

Inskeep and others (2010) studied high temperature $\left(>65^{\circ} \mathrm{C}\right)$ chemotrophic microbial communities sampled from geothermal springs (or pools) with a wide range of variation in $\mathrm{pH}$, dissolved sulfide, dissolved oxygen, and ferrous iron. DNA studies reveal significant differences in the predominant phyla associated with 

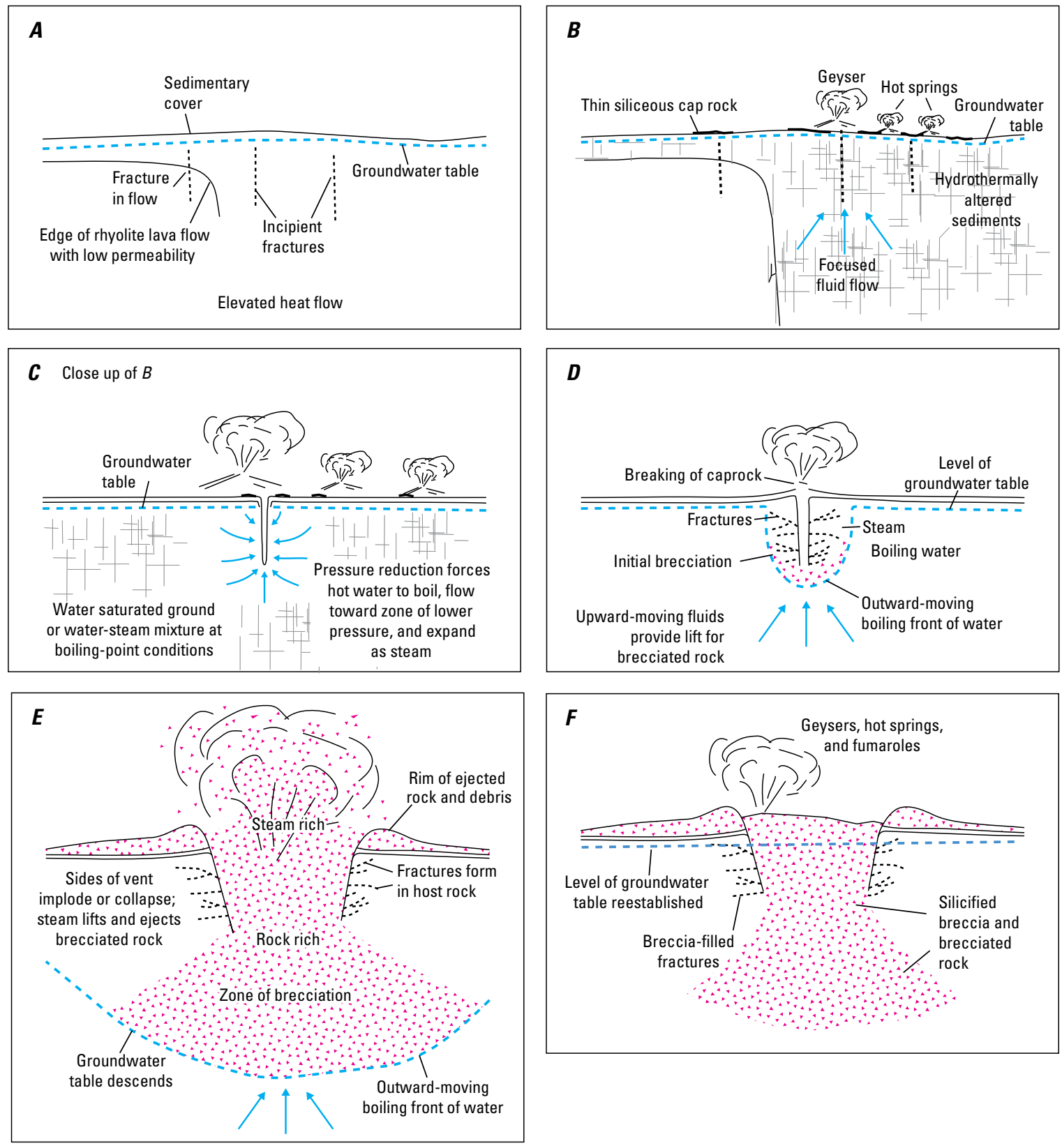

Figure 19. Diagram showing the evolution and processes associated with hydrothermal explosions. $A$, Conditions contributing to the location and development of hydrothermal systems include elevated heat flow, groundwater, and zones of weakness or focused flow such as fractures and edges of low-permeability rhyolitic lava flows. $B$, Focused flow of hydrothermal fluids in hydrothermally altered and fractured sediment creates thermal areas with hot springs, geysers, and mud pots at the surface. Over time, the subsurface becomes increasingly hydrothermally altered through a series of interconnected fluid- and gas-filled fractures. A thin siliceous cap rock forms in places. $C$, Close up of $B$. An explosion event is triggered when there is a sudden reduction in pressure in the system. The sudden pressure reduction on the water/gas-saturated hydrothermal system results in steam generation and a sudden rush of hot water toward the new zone of low pressure. $D$, A hydrothermal explosion is triggered by the sudden expansion of water into steam which causes intense fracturing of host rock. This hydro-fracturing process, in turn, creates additional zones of lower pressure along an outward- and downward-moving boiling front, sustaining the explosion. As the boiling front moves outward from the initiation point, caprock and fractured rock are ejected. $E$, The hydrothermal explosion continues as the groundwater table descends. As the boiling front advances, fluids flash to steam and lift brecciated rock, altered clays, and boiling water, which fall back to the ground as fractured material and are deposited around the crater forming an elevated rim. Clast size of ejected material decreases with increased distance from source. Hydrothermal alteration of material is extensive and reflected in the abundance of kaolin, alunite, mineralized breccia present in the resultant explosion deposit. The hydrothermal explosion stops when an insufficient amount of steam is generated and the boiling front no longer advances. At this point, the system no longer has sufficient energy (steam) to eject material. $F$, Hydrothermal activity (geysers, hot springs, and fumaroles) in and around the explosion crater continues for thousands of years. Modified from Morgan and others (2009). 

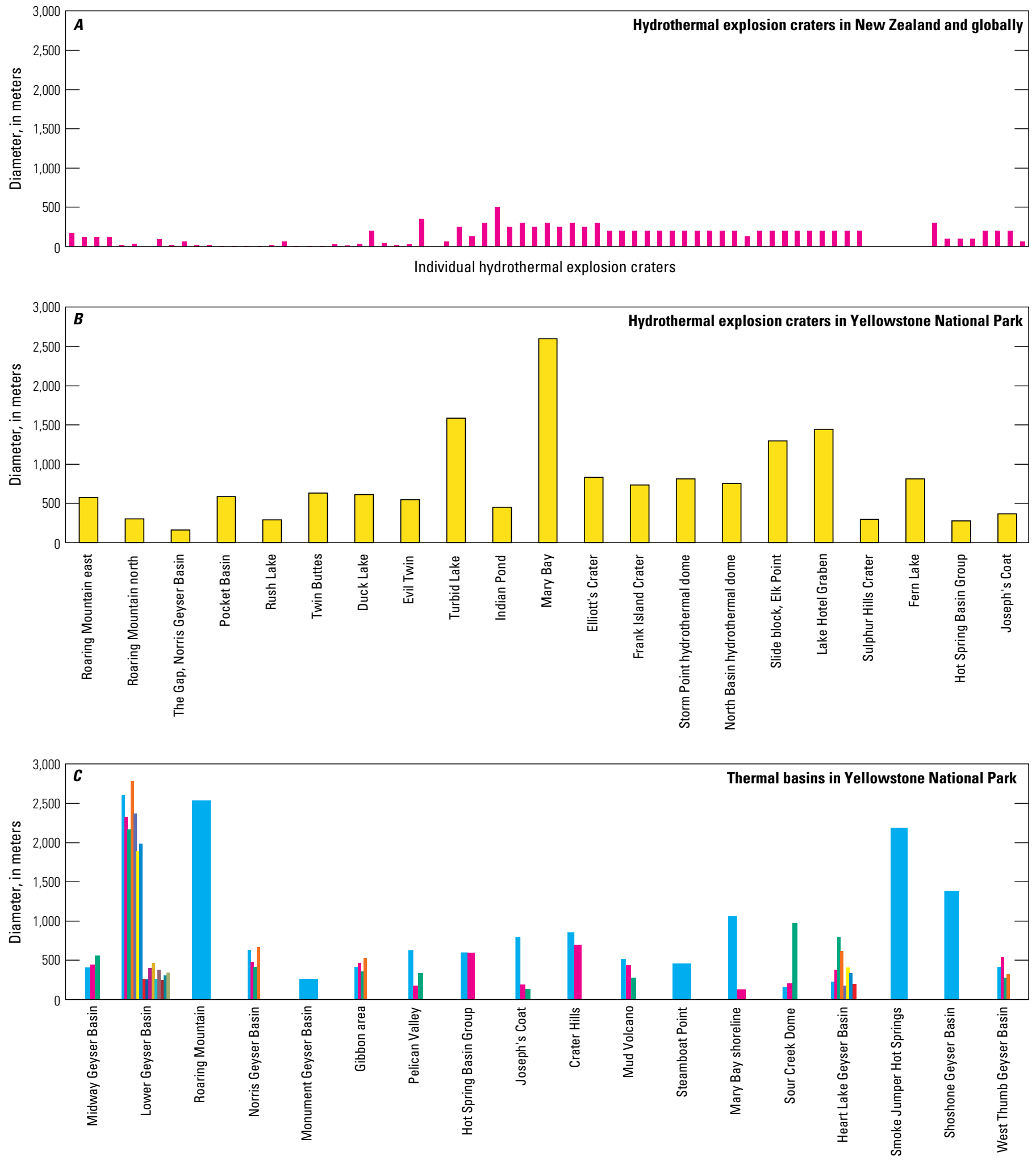

Figure 20. Bar graphs showing the maximum size of hydrothermal explosion craters and thermal basins globally and in Yellowstone National Park. $A$, Maximum diameter of hydrothermal explosion craters in New Zealand and elsewhere globally. The diameters of the majority of the hydrothermal explosion craters are less than 200 to 300 meters. $B$, Maximum diameter of large hydrothermal explosion craters in Yellowstone National Park. The diameters of the majority of the hydrothermal explosion craters are $>500$ meters. $C$, Maximum diameter of thermal areas and geyser basins in Yellowstone National Park. The diameters of the majority of these sites are $>500$ meters. Separate bars on $C$ indicate individual sub-basins. From Morgan and others (2009). 
each of the geochemical environments. In addition to temperature, geochemical parameters $\left(\mathrm{pH}\right.$, sulfide, $\mathrm{Fe}^{2+}, \mathrm{O}_{2}$ ) control microbial community structure and function in Yellowstone National Park geothermal springs. The waters, rocks, and mineral surfaces in geothermal sites provide an assortment of electron donors (hydrogen, sulfide, and ferrous iron), as well as electron acceptors (dissolved oxygen or elemental sulfur) that are energy sources for thermophilic microorganisms (Shock and others, 2010). A description of representative microorganisms and their characteristics and occurrences provides a sample of the broad diversity in Yellowstone National Park (table 4) (Yellowstone National Park, 2015).

Table 4. Representative microorganisms in Yellowstone National Park.

[Source: Yellowstone National Park, 2015. $\mathrm{pH}$ and temperature given are the conditions of survival of the bacteria. Abbreviations: ${ }^{\circ} \mathrm{C}$, degrees Celsius; ${ }^{\circ} \mathrm{F}$, degrees Fahrenheit]

\begin{tabular}{|c|c|c|c|}
\hline Name & $\begin{array}{c}\mathrm{pH} \text { and temperature } \\
\text { range }\end{array}$ & Description & Location in Yellowstone \\
\hline \multicolumn{4}{|c|}{ Thermophilic bacteria } \\
\hline \multicolumn{4}{|l|}{ Cyanobacteria } \\
\hline Calothrix & $\begin{array}{l}\mathrm{pH}: 6-9 \\
\text { Temperature: } 30-45^{\circ} \mathrm{C} \\
\left(86-113^{\circ} \mathrm{F}\right)\end{array}$ & $\begin{array}{l}\text { Color and form: dark brown mats } \\
\text { Metabolism: photosynthesis by day; fermentation by night }\end{array}$ & $\begin{array}{l}\text { - Mammoth Hot Springs } \\
\text { - Upper, Midway, and Lower Geyser Basins }\end{array}$ \\
\hline Phormidium & $\begin{array}{l}\mathrm{pH}: 6-8 \\
\text { Temperature: } 35-55^{\circ} \mathrm{C} \\
\left(95-135^{\circ} \mathrm{F}\right)\end{array}$ & $\begin{array}{l}\text { Color and form: orange mats } \\
\text { Metabolism: photosynthesis }\end{array}$ & $\begin{array}{l}\text { - Mammoth Hot Springs } \\
\text { - Upper, Midway, and Lower Geyser Basins }\end{array}$ \\
\hline Oscillatoria & $\begin{array}{l}\mathrm{pH}: 6-8 \\
\text { Temperature: } 36-45^{\circ} \mathrm{C} \\
\left(96-113^{\circ} \mathrm{F}\right)\end{array}$ & $\begin{array}{l}\text { Color and form: orange mats } \\
\text { Metabolism: photosynthesis }\end{array}$ & $\begin{array}{l}\text { - Mammoth Hot Springs } \\
\text { - Chocolate Pots }\end{array}$ \\
\hline Synechococcus & $\begin{array}{l}\mathrm{pH}: 7-9 \\
\text { Temperature: } 52-74^{\circ} \mathrm{C} \\
\left(126-165^{\circ} \mathrm{F}\right)\end{array}$ & $\begin{array}{l}\text { Color and form: green mats } \\
\text { Metabolism: photosynthesis by day; fermentation by night }\end{array}$ & $\begin{array}{l}\text { - Mammoth Hot Springs } \\
\text { - Upper, Midway, and Lower Geyser Basins }\end{array}$ \\
\hline Green sulfur & & & \\
\hline Chlorobium & $\begin{array}{l}\mathrm{pH}: 6-9 \\
\text { Temperature: } 32-52^{\circ} \mathrm{C} \\
\left(90-126^{\circ} \mathrm{F}\right)\end{array}$ & $\begin{array}{l}\text { Color and form: dark green mats (dense) } \\
\text { Metabolism: anaerobic photosynthesis; produces sulfate and } \\
\text { sulfur, not oxygen }\end{array}$ & $\begin{array}{l}\text { - Mammoth Hot Springs } \\
\text { - Calcite Springs }\end{array}$ \\
\hline Green non-sulfur & & & \\
\hline Chloroflexus & $\begin{array}{l}\mathrm{pH}: 7-9 \\
\text { Temperature: } 35-85^{\circ} \mathrm{C} \\
\left(95-185^{\circ} \mathrm{F}\right)\end{array}$ & $\begin{array}{l}\text { Color and form: green mats } \\
\text { Metabolism: anaerobic photosynthesis }\end{array}$ & $\begin{array}{l}\text { - Mammoth Hot Springs } \\
\text { - Upper, Midway, and Lower Geyser Basins }\end{array}$ \\
\hline Aquifex & & & \\
\hline Hydrogenobaculum & $\begin{array}{l}\mathrm{pH}: 3-5.5 \\
\text { Temperature: } 55-72^{\circ} \mathrm{C} \\
\left(131-162^{\circ} \mathrm{F}\right)\end{array}$ & $\begin{array}{l}\text { Color and form: yellow and white streamers } \\
\text { Metabolism: uses hydrogen, hydrogen sulfide, and carbon } \\
\text { dioxide as energy sources; can use arsenic in place of } \\
\text { hydrogen sulfide }\end{array}$ & $\begin{array}{l}\text { - Norris Geyser Basin } \\
\text {-Amphitheater Springs }\end{array}$ \\
\hline Deinococcus-Therm & & & \\
\hline Thermus & $\begin{array}{l}\text { pH: } 5-9 \\
\text { Temperature: } 40-79^{\circ} \mathrm{C} \\
\left(104-174^{\circ} \mathrm{F}\right)\end{array}$ & $\begin{array}{l}\text { Color and form: bright red or orange streamers; contains } \\
\text { carotenoid pigments that act as sunscreen } \\
\text { Metabolism: uses several substrates for growth, including } \\
\text { carbohydrates, amino acids, carboxylic acids, and peptides }\end{array}$ & - Lower Geyser Basin \\
\hline & & Thermophilic archaea & \\
\hline Domain Archaea & $\begin{array}{l}\mathrm{pH}: 0.9-5.8 \\
\text { Maximum temperature: } \\
>80^{\circ} \mathrm{C}\left(>176^{\circ} \mathrm{F}\right)\end{array}$ & $\begin{array}{l}\text { Color and form: no color; unicellular with a tough cell } \\
\text { membrane } \\
\text { Metabolism: chemosynthesis, using hydrogen, sulfur, carbon } \\
\text { dioxide }\left(\mathrm{CO}_{2}\right)\end{array}$ & $\begin{array}{l}\text { - In many of Yellowstone's hydrothermal features } \\
\text { - Norris Geyser Basin } \\
\text { - Lemonade Creek } \\
\text { - Nymph Creek }\end{array}$ \\
\hline Sulfolobus & $\begin{array}{l}\mathrm{pH}: 0-4 \\
\text { Temperature: } 55-80^{\circ} \mathrm{C} \\
\left(131-176^{\circ} \mathrm{F}\right)\end{array}$ & $\begin{array}{l}\text { Color and form: green, generally spherical cells producing } \\
\text { frequent lobes } \\
\text { Metabolism: can grow either lithoautotrophically by oxidizing } \\
\text { sulfur, or chemoheterotrophically using sulfur to oxidize } \\
\text { simple reduced carbon compounds }\end{array}$ & $\begin{array}{l}\text { - Norris Geyser Basin } \\
\text { - Grand Prismatic Spring } \\
\text { • Mud Volcano }\end{array}$ \\
\hline
\end{tabular}




\section{Geologic History of Yellowstone Lake}

Formation of a structural basin in the vicinity of the western edge of Yellowstone Lake may go as far back as to the collapse of the 2.08-Ma Huckleberry Ridge Caldera, when a moat zone may have been created in the collapsed portion of the caldera associated with eruption of Huckleberry Ridge Tuff member A (fig. 4) (Christiansen, 2001). Likewise, a moat zone associated with collapse of the Yellowstone Caldera extending to present-day eastern margin of Yellowstone Lake may have created additional depressions where water could accumulate. Yellowstone Lake (figs. 21,22) straddles the southeast topographic margin of the Yellowstone Caldera and is the largest high-altitude $(>2,133 \mathrm{~m})$ lake in North America.

In terms of geologic processes, the lake can be divided into two realms: (1) the northern two-thirds of the lake, within the Yellowstone Caldera, which has been shaped by processes dominated by volcanism and hydrothermal activity; and (2) the southern one-third of the lake, south of the topographic margin of the Yellowstone Caldera, which has been shaped primarily by tectonic, fluvial, and glacial processes. The entire lake has been influenced by recent tectonism and glacial activity in a lacustrine environment. High-resolution bathymetric, seismic-reflection, and aeromagnetic surveys of Yellowstone Lake have identified, in more detail, the extent of these various processes (Otis and others, 1977; Finn and Morgan, 2002; Morgan and others, 2003, 2007a, b; Shanks and others, 2007; Balistrieri and others, 2007). Multiple advances and retreats of thick glacial ice have overlapped volcanic and hydrothermal activity, leaving a lake basin shaped predominantly by fire and ice.

Detailed bathymetric and geologic maps and fluid flow models reveal that young, postcaldera rhyolitic lava flows underlie much of Yellowstone Lake and exert fundamental control on lake morphology and localization of hydrothermal activity in the northern, West Thumb, and central basins (figs. 21, 22) (Morgan and Shanks, 2005). Many other previously unknown features on the floor of Yellowstone Lake have been identified and include more than 650 hydrothermal vent craters ( 1 to $200 \mathrm{~m}$ in diameter) (figs. 12, 22), several large (as wide as $1.2 \mathrm{~km}$ in diameter) hydrothermal explosion craters, domed lacustrine sediments related to hydrothermal activity, elongate fissures and faults cutting postglacial sediments, siliceous hydrothermal-spire structures as large as $8 \mathrm{~m}$ tall, submerged former shorelines, large glacial melting features in the Southeast Arm, incipient faulting along the trace of the Eagle Bay Fault Zone, and an active graben near the northern outlet of the lake (fig. 21).

Studies of vent fluids, lake waters, and stream tributaries indicate that approximately 10 percent of the total flux of hydrothermal fluids in Yellowstone National Park occurs as sublacustrine vents in the lake, indicating that some of the park's largest geothermal fields are in Yellowstone Lake (Shanks and others, 2005; Balistrieri and others, 2007). Chemical studies of stream and lake waters indicate that hydrothermal vent fluids enrich lake waters in dissolved As, B, Cl, Cs, Ge, $\mathrm{Li}, \mathrm{Mo}, \mathrm{Sb}$, and $\mathrm{W}$ by at least an order of magnitude relative to the flow-weighted composition of in-flowing streams.
Several active hydrothermal vents on the lake floor have measured at temperatures as high as $120^{\circ} \mathrm{C}$ (Shanks and others, 2007), and more recent data indicate active venting at $173^{\circ} \mathrm{C}$ at $114 \mathrm{~m}$ depth as part of the ongoing National Science Foundation grant supporting the Hydrothermal Dynamics of Yellowstone Lake (HD-YLAKE) project (W.E. Seyfried, written commun., 2016).

Siliceous lake-floor hydrothermal deposits occur as pipes (conduits), tabular horizontal deposits (flanges), vertical joint fillings, and spires composed largely of amorphous or chalcedonic silica with included diatoms, and filamentous bacteria (Morgan and others, 2003, 2007a, b; Shanks and others, 2005, 2007). Siliceous hydrothermal conduits and spires are enriched in As, Hg, $\mathrm{Mo}, \mathrm{Tl}$, and $\mathrm{W}$ relative to normal lake sediment. Oxygen-isotope temperature calculations suggest formation of sublacustrine siliceous deposits at about 78 to $164^{\circ} \mathrm{C}$. Seismic-reflection profiles, aeromagnetic data, and field evidence suggest that lateral migration of hydrothermal fluids in the subsurface is an important and widespread process (Finn and Morgan, 2002; Johnson and others, 2003; Shanks and others, 2007). Porous sediments in recently collected piston cores from Yellowstone Lake reflect the importance of migration of hydrothermal fluids in the subsurface; here, at greater depths in the cores, many individual detrital grains have hydrothermal quartz overgrowths precipitated on them. These cores were collected in 2016 as part of the HD-YLAKE project (see fig. 21 for the piston core locations).

The South, Southeast, and Flat Mountain Arms in the southern lake are fault-controlled valleys enlarged by glaciation (figs. 21, 22). The hummocky floor of the Southeast Arm reflects many glacial-meltwater and stagnant-ice-block features associated with ponded blocks of ice from the last glacial recession. These kettle-like features are present on The Promontory (Alder Lake) but are not so apparent in the South Arm.

Geologic stages in an evolving Yellowstone Lake occurred in roughly the following sequence (fig. 23): (1) a large depression, most likely a caldera moat zone, accumulated water and sediment after the eruption and collapse of the Yellowstone Caldera; (2) a large canyon of the ancestral Yellowstone River was established prior to pre-Bull Lake Glaciation; this system flowed south to north from Southeast Arm to near the northern-basin, present-day outlet for Yellowstone Lake (Otis and others, 1977); (3) several postcaldera rhyolitic lavas flowed into the northern, central, and West Thumb basins, creating morphologically significant landforms in the lake (Stevenson, Frank, and Dot Islands are underlain by large rhyolitic lava flows); (4) the West Thumb Caldera erupted the majority of the mapped tuff of Bluff Point distributed to the west (Christiansen, 2001) and collapsed forming an 8-km-wide caldera, similar in dimension to that at Crater Lake, Oregon; (5) ice advanced and retreated multiple times during the Bull Lake and Pinedale glaciations, leaving a mantle of till on the postcaldera rhyolitic lava flows and lake floor; and (6) development of a large hydrothermal field in the northern and West Thumb basins of Yellowstone Lake with hydrothermal vents and explosion craters. An estimated ice thickness of $1 \mathrm{~km}$ filled the central and northern basins during the Pinedale glaciation; ice receded from the northern basin about 14,000 years before present (Licciardi and Pierce, 2008; Pierce and others, 2014). The crest or 


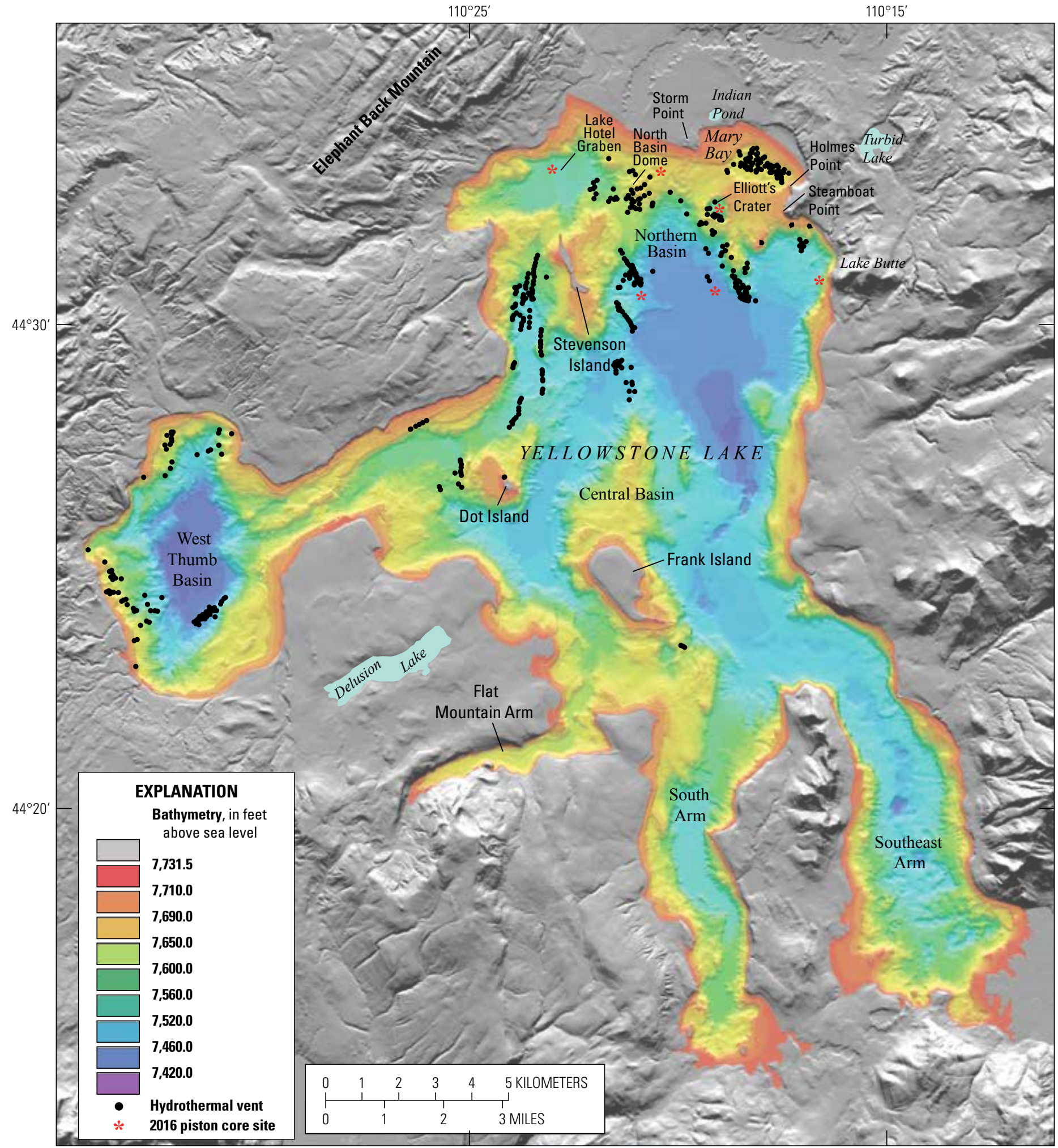

Figure 21. Bathymetric map of Yellowstone Lake. Locations of hydrothermal vents are shown with black dots. The red asterisks show sites where piston cores were collected during 2016. Modified from Morgan and others, 2007a. 

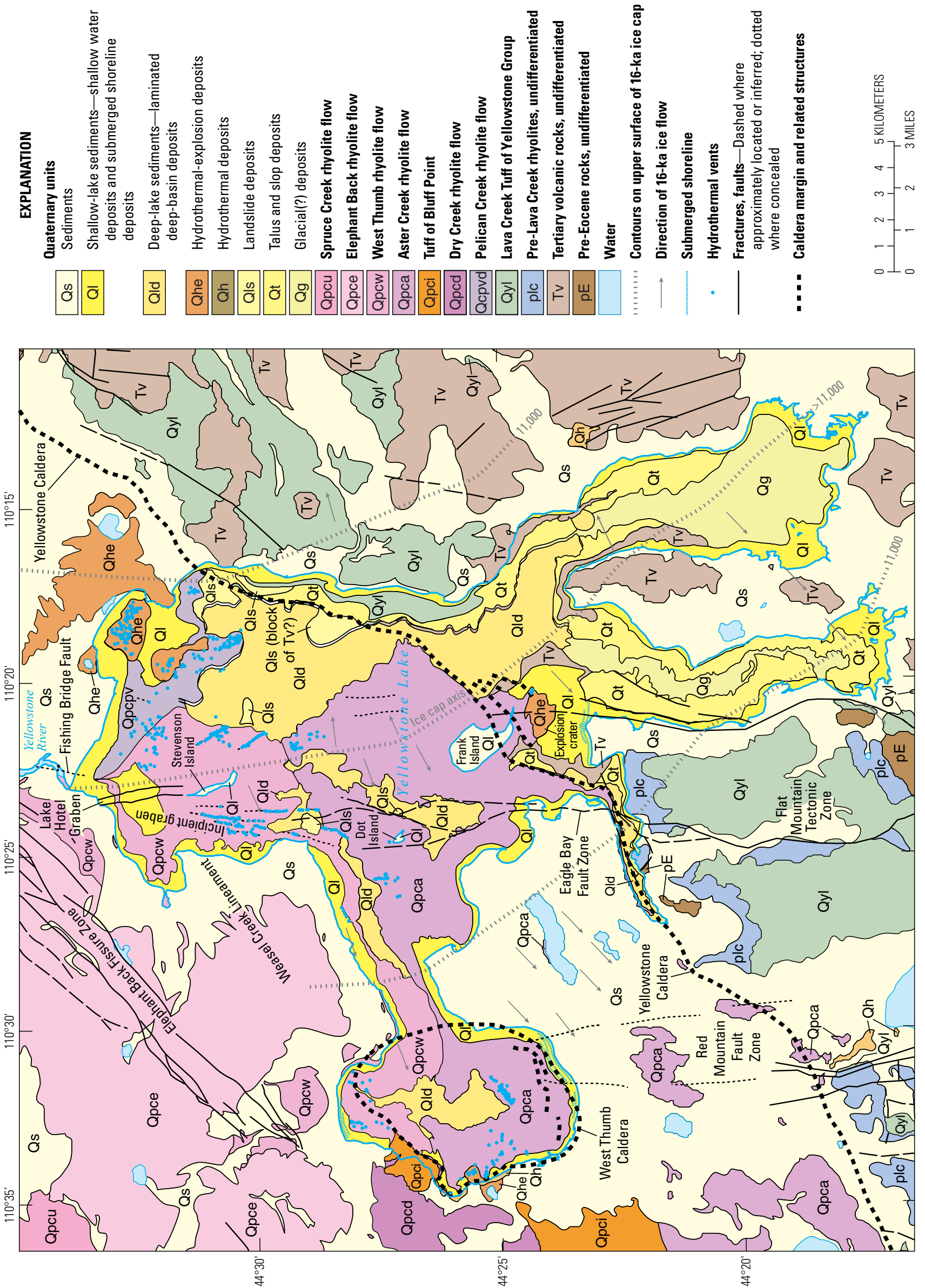

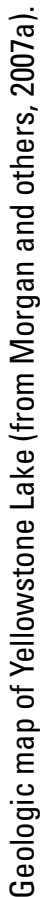
촌 


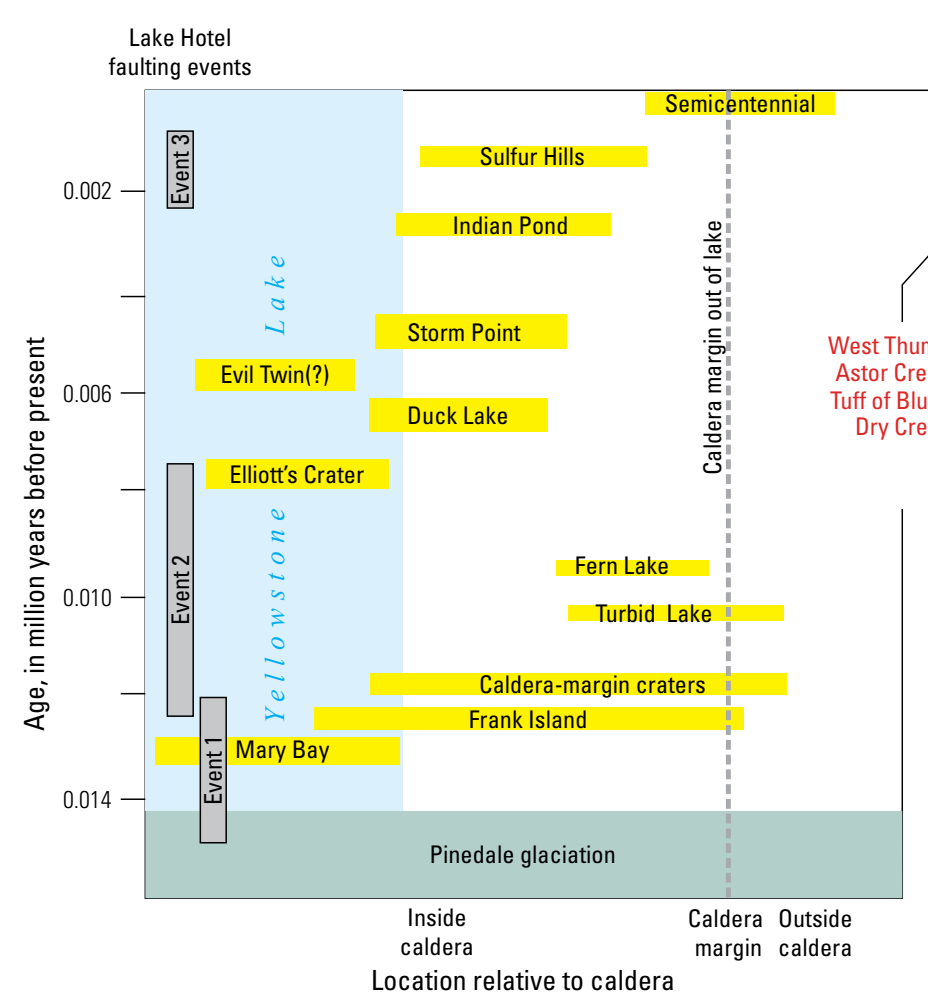

Lake Hotel Large hydrothermal explosion faulting events or doming events $0 \rightarrow$

Pinedale al

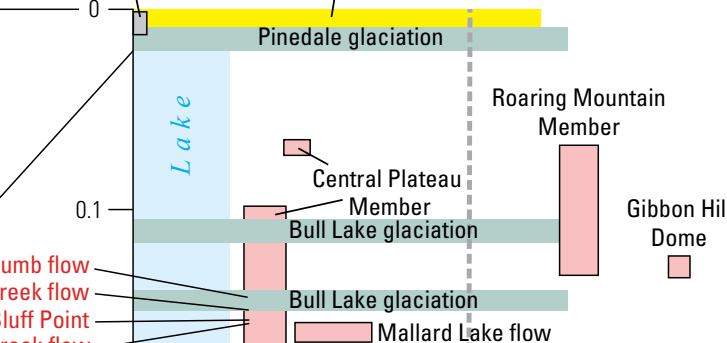

Figure 23. Schematic diagram of the geologic history of Yellowstone Lake (modified from Morgan and others, 2007a) and comparison of timing of other volcanic events on the Yellowstone Plateau. Yellow boxes represent a large hydrothermal explosion or doming event. Several rhyolitic units (identified with red text) have been mapped in Yellowstone Lake and (or) have been identified as breccia clasts within the Mary Bay hydrothermal explosion breccia (as is the case for the unmapped rhyolitic lava flow from Pelican Valley). Events 1, 2, and 3 refer to seismic events that contributed to the formation of the Lake Hotel Graben; some of these events may coincide with hydrothermal explosion events.

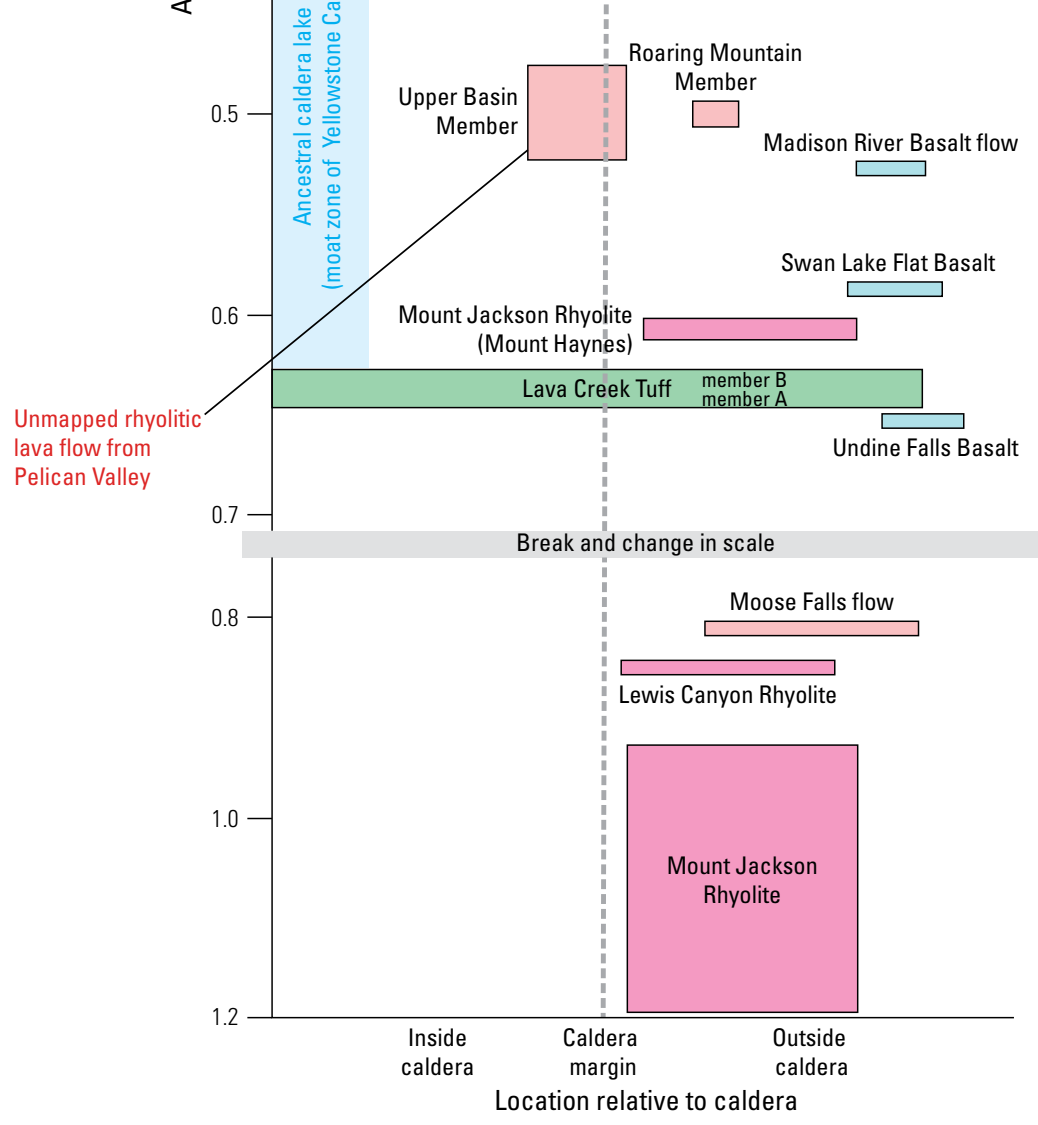


highest point of ice trended north-south as shown in figs. 11 and 22 and, thus, ice flowed off the crest to the west or east and may have contributed to scour features, such as the northeast-trending Breeze Bay between the central and West Thumb basins (also the contact between the Aster Creek flow and the West Thumb flow) and (or) the northeast orientation of Delusion Lake (fig. 21). Lake level changes are well documented (Pierce and others, 2007; Locke and others, 1992; Locke and Meyer, 1994; Meyer and Locke, 1986) and suggest millennial-scale variations in lake level and hydrothermal activity (Pierce and others, 2007).

\section{Yellowstone Seismicity}

Yellowstone is well known as one of the most seismically active areas in the Intermountain West. Over 44,000 earthquakes $\left(-1.0<\mathrm{M}_{\text {сомР }}<6.1\right)$ have been located in the Yellowstone region with an annual rate of 1,500 to 2,000 earthquakes per year since 1973 (Farrell and others, 2009) (fig. 24). Furthermore, the Yellowstone area has experienced the largest historic earthquake in the Intermountain West, the August 1959 Hebgen Lake, Montana, earthquake $\left(\mathrm{M}_{\mathrm{w}} 7.3\right)$ located $\sim 25 \mathrm{~km}$ northwest of the Yellowstone Caldera (Doser, 1985). This earthquake occurred on the two southdipping fault planes of the Hebgen Lake and Red Canyon Faults, which are Basin-and-Range-style normal faults. The caldera also has experienced a $M_{L} 6.1$ earthquake in 1975 southeast of Norris Junction (Pitt and others, 1979; Smith and Arabasz, 1991).

Overall, seismic activity in Yellowstone is characterized by episodic occurrences of small, generally shallow, earthquake swarms (Farrell and others, 2009, 2010; Shelly and others, 2013). The most intense area of seismicity extends from the Hebgen Lake area east to the northern caldera boundary near Norris Junction (fig. 24). Although this area only constitutes 16 percent of the area, it contains 75 percent of the earthquakes. Linear bands of earthquakes occur within and adjacent to the caldera and are aligned generally north-northwest, parallel to alignments of postcaldera volcanic vents and nearby large regional normal faults. These faults are cut by the Yellowstone Caldera and are hypothesized to have once been continuous Basin-and-Range faults (Smith and Seigel, 2000; Christiansen, 2001).

\section{Notable Periods of Unrest: 1985-2015}

Geodetic measurements (global positioning system [GPS] and spirit leveling) in Yellowstone began when the road system was established in 1923. After resurveying the extensive network of leveling benchmarks for the vertical component of deformation in 1975, 1976, and 1977, Pelton and Smith (1982) discovered an extraordinary 740 millimeters $(\mathrm{mm})$ of uplift in a $\sim 50$ year time period, averaging $\sim 15$ millimeters per year $(\mathrm{mm} / \mathrm{yr})$. Subsequent leveling found different rates of uplift in the northeast and southwest parts of the caldera continuing though 1984 (Dzurisin and others, 1990). An episode of caldera subsidence at $10 \pm 2 \mathrm{~mm} / \mathrm{yr}$ that began in 1984 to 1985 was first measured by the first GPS campaigns, giving an estimate of both vertical and horizontal deformation rates (Meertens and
Smith, 1991). More recent Interferometric Synthetic Aperture Radar (InSAR) measurements between 1992 and 2003 revealed changing centers of subsidence and uplift in the northwest caldera boundary region (Wicks and others, 1998, 2006). In 2004, the Yellowstone Caldera entered a period of accelerated uplift (fig. 25) with rates as high as 7 centimeters per year (cm/yr) (Chang and others, 2007, 2010). Using both GPS and InSAR data, the uplift was modeled as an inflating sill near the top of a tomographically imaged magma reservoir at about 8 to $10 \mathrm{~km}$ depth (Chang and others, 2007, 2010).

Uplift of the northern caldera from 1996 to 2003 was accompanied by high heat flow, changes in geyser periodicity, and the creation of new thermal features near Norris Junction (Wicks and others, 2006; Dawson and others, 2012). Wicks and others (2006) speculated that dilatation associated with the uplift resulted in increased hydrothermal flow. Another remarkable event during the early 2000s was the dynamic triggering of hundreds of local earthquakes, as well as geyser eruptions, due to passage of seismic waves originating in Alaska from the $2002 \mathrm{M}_{\mathrm{w}} 7.9$ Denali earthquake (Husen, Taylor, and others, 2004). Clearly, the stress regime within the upper crust and hydrothermal system can be sensitive to outside perturbations, though the timing and magnitude of unrest may vary widely.

Overall, Yellowstone experiences decadal periods of uplift and subsidence that are believed to be due to magma migration during recharge of crustal magma reservoirs (fig. 26). Notably, large earthquake swarms in Yellowstone appear to be correlated with the onset of periods of deformation reversal (fig. 26), suggesting that these swarms are an indication of fluid movement in the shallow crust escaping the caldera into the surrounding region. The three largest modern Yellowstone swarms all coincided with one of these deformation reversals.

The 1985 swarm, the largest swarm to be recorded in Yellowstone, occurred near the northwest boundary of the Yellowstone Caldera and was modeled as a migrating swarm moving $\sim 150$ meters per day to the northwest and outward from the caldera (Waite and Smith, 2002). This swarm coincided with a caldera deformation reversal from uplift to subsidence.

The 2008 to 2009 Yellowstone Lake swarm occurred beneath northern Yellowstone Lake and had an unusually high migration rate of $\sim 1 \mathrm{~km}$ per day with shallowing focal depths through time from 10 to $2 \mathrm{~km}$ (Farrell and others, 2010; Massin and others, 2013). The accelerated uplift rate decreased from $\sim 3.5 \mathrm{~cm} / \mathrm{yr}$ to $\sim 1.7 \mathrm{~cm} / \mathrm{yr}$ after this swarm (fig. 26).

The 2010 Madison Plateau swarm on the western caldera boundary occurred about $10 \mathrm{~km}$ to the south of the $1985 \mathrm{swarm}$ and showed similar focal mechanisms and source geometries (Massin and others, 2013; Shelly and others, 2013). Following the 2010 swarm, caldera deformation reversed from uplift at a rate of $\sim 1.7 \mathrm{~cm} / \mathrm{yr}$ prior to the swarm to $\sim 2.6 \mathrm{~cm} / \mathrm{yr}$ of subsidence (fig. 26). It is hypothesized that the movement of magma or magmatically derived fluids triggers these swarms as they move away from the caldera (Massin and others, 2013; Shelly and others, 2013). The escaping fluids, in turn, cause a pressure decrease that allows the caldera to move into a phase of subsidence. Though most workers seem to favor such a model, 


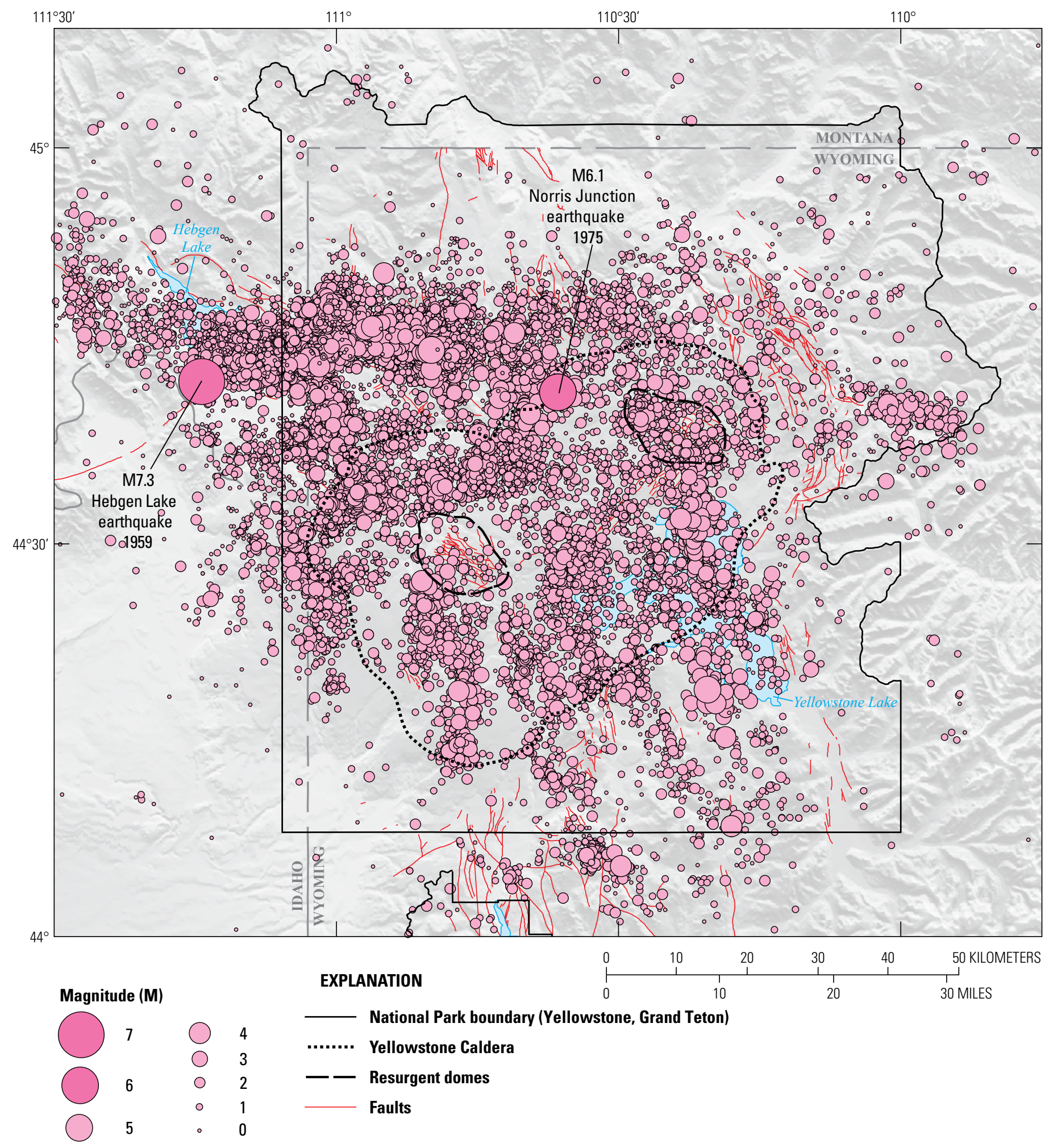

Figure 24. Map showing earthquakes at Yellowstone National Park and the surrounding area recorded by the Yellowstone Seismic Network from 1972 to the present. Courtesy of the University of Utah Seismograph Stations (http://quake.utah.edu/). 


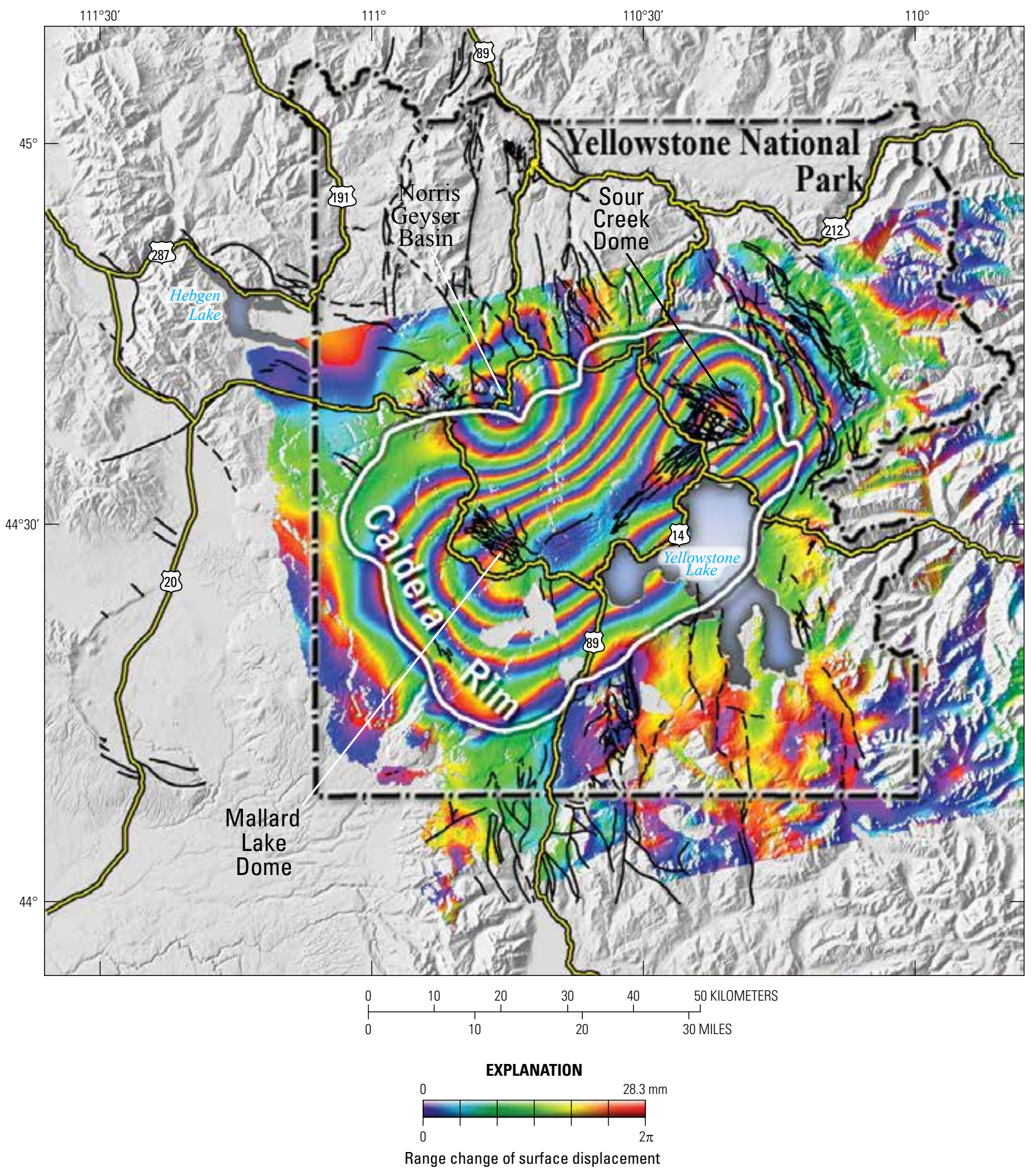

Fault-dashed where inferred

Figure 25. Interferometric synthetic aperture radar (InSAR) image of Yellowstone National Park showing the range change of ground surface to satellite for the period from September 2004 to August 2006. The range of colors from violet to red in each band is equivalent to approximately 28 millimeters $(\mathrm{mm})$ of surface displacement between a point on the ground and the satellite. The amount of surface displacement indicates about $110 \mathrm{~mm}$ of total uplift in the western part of the caldera at Mallard Lake Dome, about $150 \mathrm{~mm}$ of uplift in the eastern part of the caldera at the Sour Creek Dome, and about 60 to $70 \mathrm{~mm}$ of subsidence near the Norris Geyser Basin. The Yellowstone Caldera rim is shown with the white line. Modified from Waite and Smith (2002). 


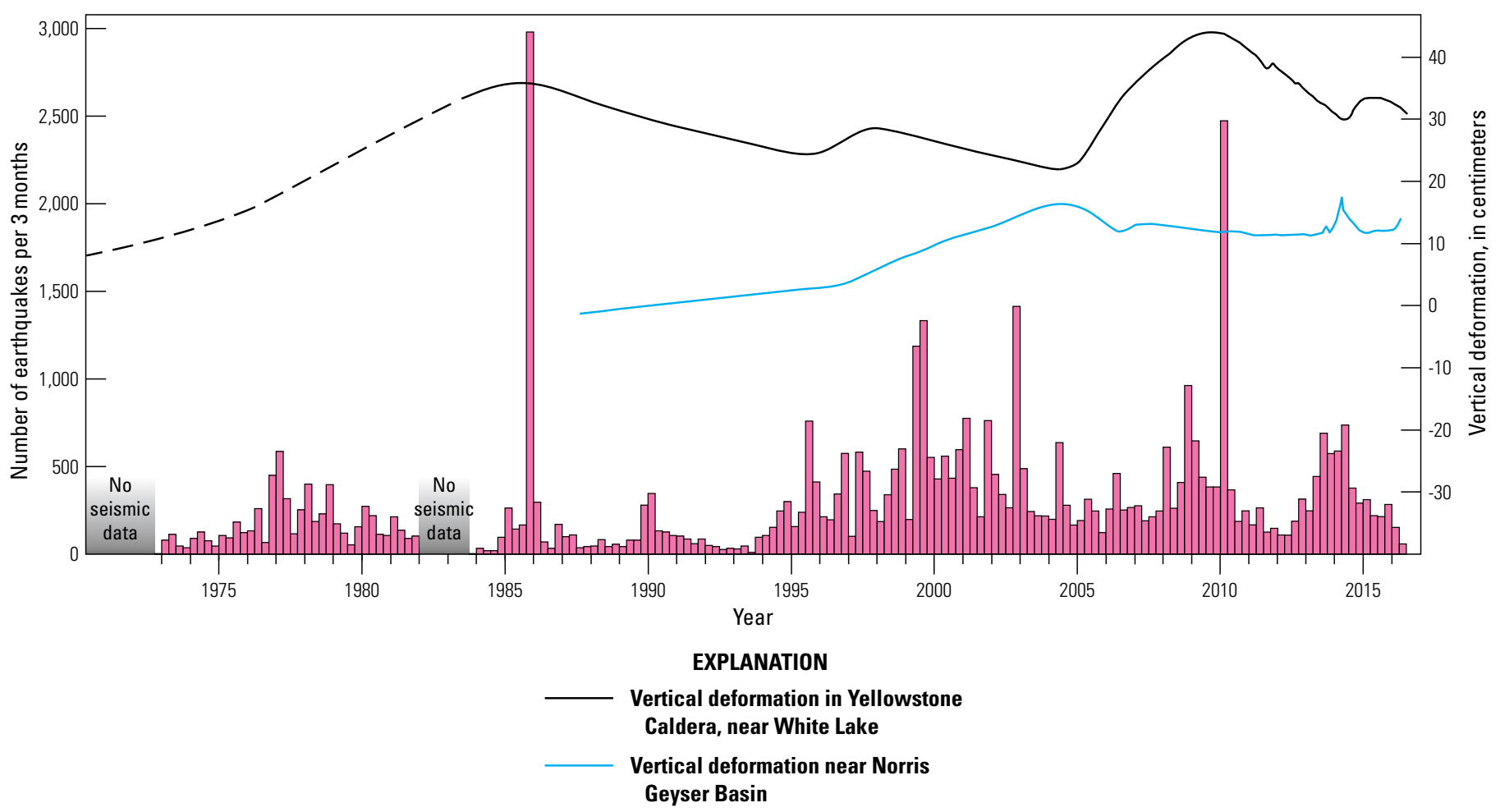

Figure 26. Overview graph of seismicity and ground deformation in the Yellowstone Caldera. Blue line is recorded deformation from a global positioning system (GPS) station near Norris Geyser Basin; black line is recorded deformation from a GPS station near White Lake within the Yellowstone Caldera near the Sour Creek resurgent dome (GPS data from UNAVCO [https://www. unavco.org/]); dashed line is inferred deformation from the time the roads were first surveyed in 1923 and the leveling campaign in the middle 1970s (Pelton and Smith, 1982); pink bars represent all recorded earthquakes in the Yellowstone region per quarter of each year shown. Earthquake data from the three-dimensional velocity model of Farrell and others (2014) and University of Utah Seismograph Stations (http://quake.utah.edu/).

it is challenging to detect the presence of any escaping fluids at the surface due to the difficulty of geochemical surveillance over the broad Yellowstone region. Existing geochemical monitoring (solute flux) has not detected correlations between water chemistry or flow and either uplift/subsidence cycles or seismic swarms (Hurwitz and Lowenstern, 2014).

The Norris Geyser Basin region experienced an episode of high-rate uplift and subsequent subsidence related to an episode of intense swarm activity surrounding the region in 2013 to 2014. Uplift began in the region around October 2013 coincident with a few earthquake swarms to the west of Norris Geyser Basin. This deformation episode intensified with uplift rates $>12 \mathrm{~cm} / \mathrm{yr}$ and ongoing swarm activity to the west and north of Norris through the beginning of 2014. The largest swarm in the sequence began in late March 2014 and culminated with a $\mathrm{M}_{\mathrm{w}} 4.8$ earthquake just northeast of Norris, the largest earthquake to occur in Yellowstone in more than 30 years. Concurrent with the $\mathrm{M}_{\mathrm{w}} 4.8$ earthquake, deformation reversed to subsidence in the Norris area with rates $>40 \mathrm{~cm} / \mathrm{yr}$. Swarm activity continued at much lower rates during the subsidence period and by late 2014 and early 2015 deformation rates returned to background levels. During this entire episode centered on Norris, caldera deformation returned to a brief period of uplift that lasted until early 2015 (Farrell and others, 2014b).

\section{Yellowstone National Park and the Yellowstone Volcano Observatory}

Yellowstone National Park was founded in 1872 after a series of expeditions yielded an incredible wealth of photographs, descriptions, and artwork about the high plateau at the source of the Yellowstone River. In 1869 and 1870, the FolsomCook-Peterson and Washburn-Langford-Doane Expeditions, respectively, provided sufficient information to stoke the interest of the public. In 1871, Ferdinand Hayden, head of the U.S. Geological and Geophysical Survey, led a survey of the Yellowstone area with a full staff of scientists as well as a photographer, William Henry Jackson, and artists Henry Elliott and Thomas Moran. The artwork and careful documentation of unique thermal features and geological formations inspired the U.S. Congress to pass the Yellowstone National Park Protection Act, creating the world's first national park. For the first five years, however, no funds were appropriated to maintain or protect the 
park. Even after funding was granted, Yellowstone was ravaged by poachers, squatters, and loggers. At the request of the Secretary of the Interior, the U.S. Army was asked for assistance to oversee park operations. Legacy of the army's 30+ years of management can be seen in the architecture of the buildings at park headquarters (Mammoth Hot Springs). As more national parks were created across the country, it became clear that a new agency was needed to manage the national parks. In 1916, the National Park Service (NPS) was established within the Department of the Interior, and over the next two years, the Army force withdrew entirely, leaving the NPS to run Yellowstone.

The early descriptions of the area by Hayden (1872) made it clear that the Yellowstone area was a volcanic region that had undergone massive eruptions, and that the geothermal features were in some way linked to that earlier volcanic activity:

...it is probable that during the Pliocene period the entire country drained by the sources of the Yellowstone and the Columbia was the scene of as great volcanic activity as that of any portion of the globe. It might be called one vast crater, made up of thousands of smaller volcanic vents and fissures out of which the fluid interior of the earth, fragments of rock, and volcanic dust were poured in unlimited quantities .... Indeed, the hot springs and geysers of this region, at the present time, are nothing more than the closing stages of that wonderful period of volcanic action that began in Tertiary times (Hayden, 1872, p. 81).

Undoubtedly, the Hayden expedition experienced some of the continuing activity of this long-active system; a swarm of earthquakes on August 20,1871, rocked their camp near Mary Bay at the north end of Yellowstone Lake. Jaggar (1922), the founder of the Hawaiian Volcano Observatory, also exhorted the active nature of Yellowstone and encouraged the development of an observatory to track changes over time. Not until the 1960s, however, did scientists begin to acknowledge that the Yellowstone area was a still-active volcanic system with considerable volcanic hazards and potential for future activity. Boyd (1961) recognized the recent history of large volcanic eruptions and the mapping and geochronology of Christiansen and Blank (1972) made it clear that multiple massive eruptions had occurred in the Quaternary. Soon thereafter Eaton and others (1975) laid out the evidence for a large subterranean magma chamber based on geologic, geophysical, and thermal evidence. Changes in lake level hinted that the caldera also might experience tumescence. A survey to re-level the Yellowstone road system revealed large changes in ground elevation within the caldera (Pelton and Smith, 1979). The Yellowstone seismic network (fig. 27) was installed by the USGS in the 1970s and was later transferred to the University of Utah. A series of geophysical studies as summarized in Smith and Braile (1994) and later Smith and others (2009) described the impressive gravity, thermal, and seismic anomalies associated with the Yellowstone Caldera.
In 2001, the USGS combined forces with the University of Utah and Yellowstone National Park to form the Yellowstone Volcano Observatory (YVO), joining the other USGS volcano observatories in Hawaii, Alaska, the Cascades, and California. Under YVO, the three partners assembled a monitoring plan (Yellowstone Volcano Observatory, 2006), a hazards assessment (Christiansen and others, 2007), and a response plan (Yellowstone Volcano Observatory, 2010, 2014). The monitoring plan was used as the basis for improvements to the seismic, geodetic, and geochemical instrumentation undertaken in 2010 and 2011 under the American Recovery and Reinvestment Act of 2009 , which provided about $\$ 1$ million for improvements to the YVO monitoring system. In 2013, the observatory was expanded to include eight different agencies, including the three original groups, as well as the three geological surveys of Montana, Wyoming, and Idaho, the University of Wyoming, and the University NAVSTAR Consortium (UNAVCO), which administers, on behalf of the National Science Foundation, the facilities of the Plate Boundary Observatory, including the GPS network and borehole strainmeters and seismometers.

Today, the Yellowstone Seismic Network (fig. 27) contains 38 seismometers (including related telemetry equipment). Most of it is operated by the University of Utah with contributions of additional data made by nearby seismic networks operated by the Montana Bureau of Mines and Geology, the Idaho National Laboratory, and the USGS. The Plate Boundary Observatory operates 24 GPS receivers, 6 seismometers, 5 strainmeters, and 6 tiltmeters that also are critical to monitoring the Yellowstone volcanic system. Geothermal emissions are tracked primarily with streamgages equipped with specific conductance probes. Correlations in sulfate and chloride with specific conductance permit the tabulation of solute emissions at 15-minute intervals on USGS streamgages (McCleskey and others, 2010).

\section{Road Log}

Numbers at left are distances in miles from starting point. Number in bold at the end of each entry is the distance in miles to the next entry.

\section{Day 1: Meet at Bozeman in the Late Afternoon (Fig. 1.)}

The field trip will begin with an evening lecture to prepare the group for the coming six days of field observations.

\section{Day 2: Bozeman to Old Faithful via West Yellowstone, Montana (Figs. 1, 28)}

Meet at Bozeman Yellowstone International Airport. Take Alaska Road South across Interstate 90 (I-90), to the junction with East Cameron Bridge Road. 2.5 


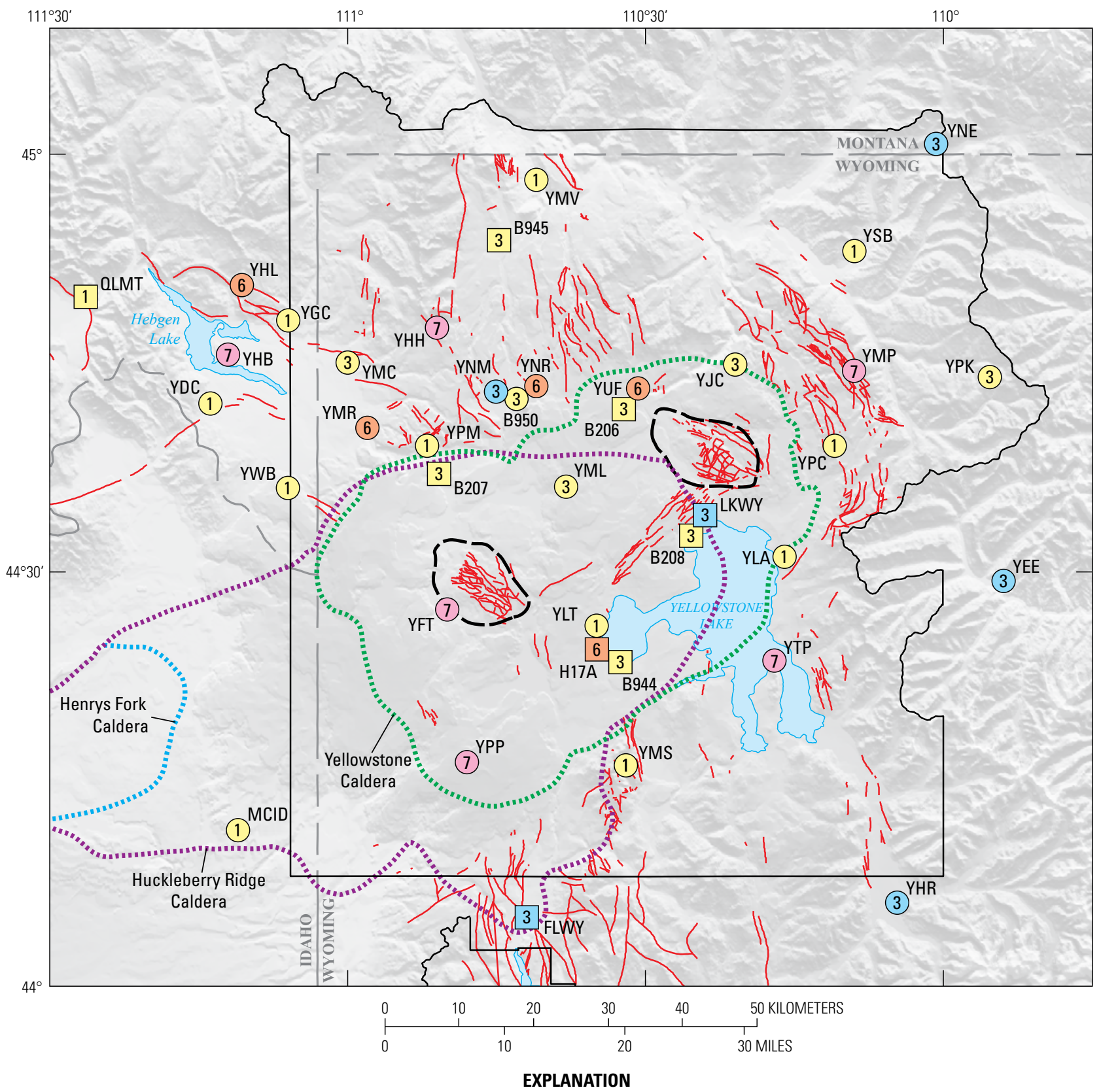

\begin{tabular}{|l|l}
\multicolumn{1}{c}{$\begin{array}{c}\text { Non-UUSS imported seismograph station } \\
\text { Broadband, strong-motion }\end{array}$} \\
\hline$\square$ Broadband \\
Short-period \\
UUSS seismograph station \\
Broadband, strong-motion \\
Broadband \\
Short-period \\
Broadband, strong-motion, short-period
\end{tabular}

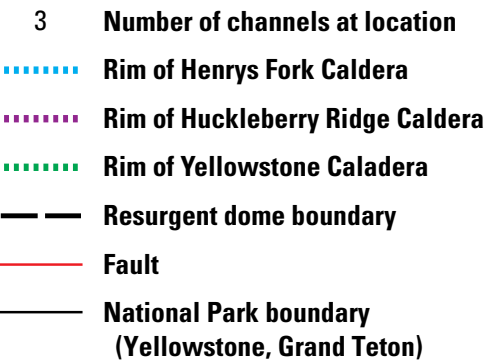

Figure 27. Map of the Yellowstone Seismic Network as of 2016. Squares represent non-UUSS imported seismograph stations operated by the U.S. Geological Survey (LKWY, FLWY), the Plate Boundary Observatory (B206, B207, B208, B944, B945, B950), the Transportable Array (H17A), and the Montana Bureau of Mines and Geology (OLMT). Circles represent seismographs operated by the University of Utah Seismograph Stations (UUSS). From the University of Utah Seismograph Stations (http://quake.utah.edu/). 
2.5 Turn right on East Cameron Bridge Road. 1.0

3.5 Turn left onto Montana Highway 85 (MT-85) South/ Jackrabbit Lane. $\mathbf{5 . 5}$

9.0 Road will continue through Four Corners as U.S. Route 191. 5.5

14.5 Pass Gallatin Gateway Inn, a relic of the early competition to become the most popular gateway to Yellowstone National Park. 7.6

22.1 After entering Gallatin Canyon (fig. 1), note an excellent exposure of Archean gneiss saturated by pegmatite veins and dikes. $\mathbf{3 6 . 9}$

59.0 Crown Butte (fig. 1, inset), is capped by 2.08-Ma Huckleberry Ridge Tuff, the deposit from the first-cycle caldera of the YPVF, whose total volume is estimated at $2,500 \mathrm{~km}^{3}$. It sits here upon Cretaceous rocks. After a short distance, we will pass through a northwest slice of Yellowstone National Park, passing thick sections of Paleozoic carbonates and sediment, Precambrian metamorphic rocks, Tertiary (Absaroka) volcanic rocks, and the Huckleberry Ridge Tuff. 24.0

83.0 Turn right onto U.S. Route 287 North.

Discuss Hebgen Lake Fault Zone and 1959 earthquake. 13.8

96.8 Turn right into Cabin Creek Earthquake Scarp Exhibit. $\mathbf{5 . 5}$

\section{Stop 1a. Hebgen Lake Fault Scarp}

Here we see the $\sim 6$-m-high scarp produced by the rupture of the Hebgen Lake Fault during the 1959 Hebgen Lake earthquake. 5.5

102.3 Turn into the parking lot of Earthquake Lake Visitor Center (lat $44.83092^{\circ} \mathrm{N}$., long $111.42546^{\circ} \mathrm{W}$.)

\section{Stop 1b. Earthquake Lake Visitor Center}

The Madison slide occurred on the south side of the canyon in Precambrian rocks of gneiss, schist, and dolomite dipping into the canyon. The slide was induced by the 1959 Hebgen Lake earthquake. The slide crossed the canyon with sufficient momentum to climb the south wall to a height of $130 \mathrm{~m}$ above the riverbed (fig. 29). The air blast related to the slide blew away people and cars. Nineteen people were buried by the slide and remain entombed beneath the 80 million tons of debris. Seven others suffered fatal injuries or died when hit by rocks, were washed away by a 9-m-tall, slide-induced wave, or were drowned as river water rapidly backed up behind the slide. Two were crushed in their tent by a falling boulder at Cliff Lake Campground, $11.3 \mathrm{~km}$ southwest of here (Smith and Siegel, 2000), making a total of 28 who perished from the earthquake. The slide dammed the Madison River to create Earthquake Lake (locally known as Quake Lake). Heavy equipment was rapidly brought in to create a stable overflow channel and lower the level of Quake Lake (U.S. Geological Survey, 1975; Witkind and Stickney, 1987; Morgan and others, 2008).

102.3 Turn left on U.S. Route 287 and return to U.S. Route 191. Time on this field trip is not sufficient to go farther south on U.S. Route 191 and explore aspects of recent glaciation, faulting, and exposures related to the 1.30Ma Henrys Fork Caldera but, for those interested in this fuller perspective of the evolution of the YPVF, two sites the reader may visit in this vicinity include the following:

1. East of the entrance to Henrys Lake (fig. 1) State Park, the road ascends an old alluvial fan. Continue toward the park entrance station. Cross the old alluvial fan to the top of a strand of the 9-m-high Centennial fault scarp (Morgan and others, 2008). Estimates for the age of this scarp range from $\sim 140 \mathrm{ka}$ (Bull Lake stage) to as young as $75 \mathrm{ka}$, based on thickness of carbonate buildup on Pinedale calcic soils.

2. As one continues farther south on U.S. Route 191, inside the 1.30-Ma Henrys Fork Caldera, (secondcycle caldera of the YPVF, a number of basalt lava flows $<0.5$ Ma are present (Abedini, 2009). 17.7

113.2 Turn south on U.S. Route 20/U.S. 191 toward the town of West Yellowstone. $\mathbf{8 . 3}$

131.5 Enter the town of West Yellowstone. Continue east on U.S. Route 20 through town; continue east past intersection of Firehole Avenue (U.S. Route 20) and Canyon Street (U.S. Route 191) one block. Turn right (south) onto Boundary Street. Go south 2 blocks. 0.2

131.7 Turn left onto U.S. Route 191. After a short distance you will enter the west entrance of Yellowstone National Park. Pay entrance fee. $\mathbf{1 . 3}$

133.0 Drive east along the Madison River (fig. 28). Here we can consider the bimodal nature of the YPVF. Exposed volcanic rock related to Yellowstone volcanism is approximately 85 to 90 percent rhyolite $(\sim 74$ percent $\mathrm{SiO}_{2}$ ) and less than 15 percent basalt ( $\sim 48$ to 51 percent $\mathrm{SiO}_{2}$ ).

About 5 miles $(\sim 8 \mathrm{~km})$ east of the park entrance (fig. 1, inset), note the ridge/small domes to the north. Most of these small hills are the postcaldera Madison River Basalt; the northwest ridge is a postcaldera, extracaldera rhyolite. To the south, a series of larger hills 


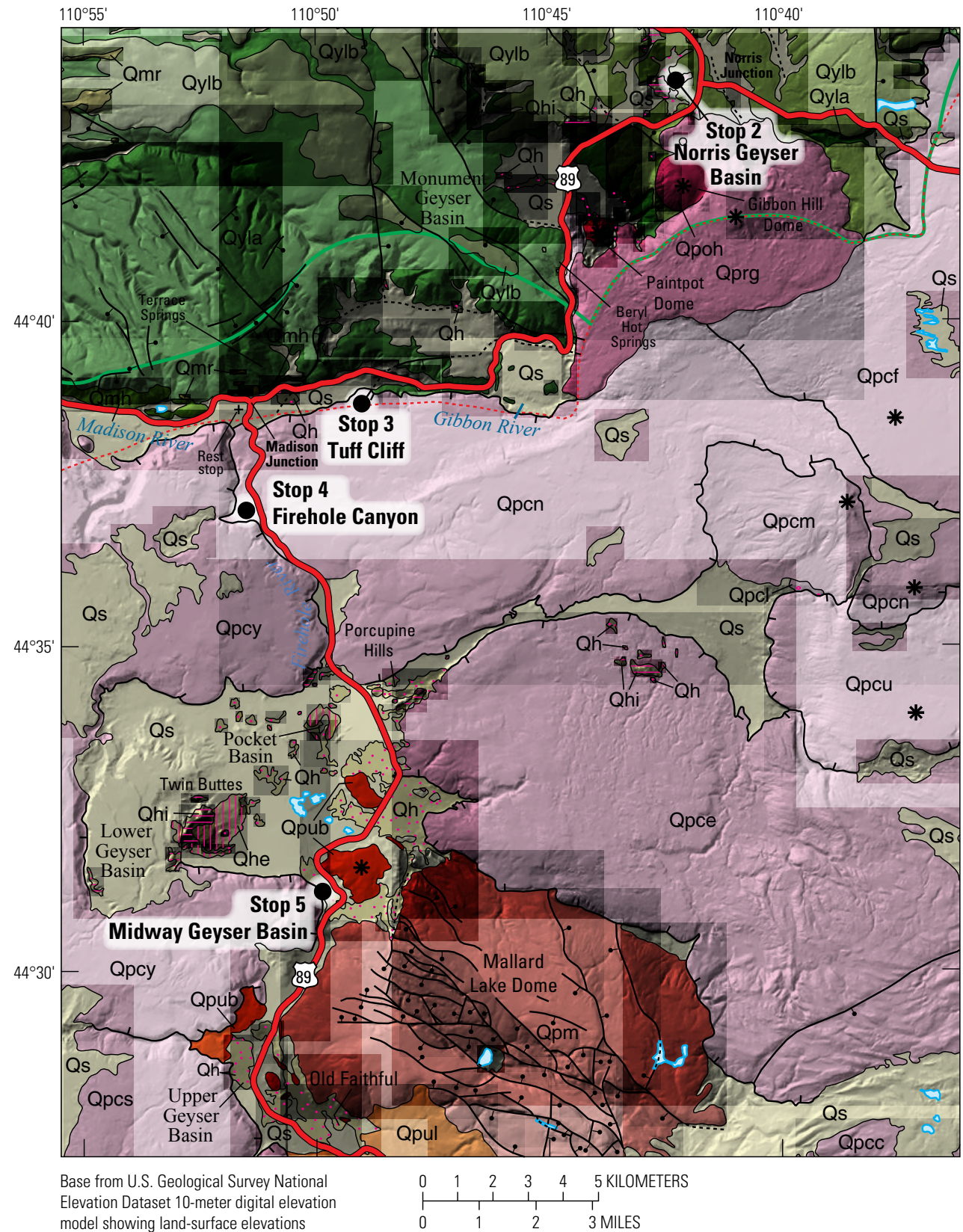

\begin{tabular}{|c|c|}
\hline & EXPLANATION \\
\hline Os & Surficial deposits \\
\hline Qh: & Hot-spring deposits \\
\hline EQhï & $\begin{array}{l}\text { Cemented ice-contact deposits } \\
\text { localized by hot springs }\end{array}$ \\
\hline Qhe & Hydrothermal-explosion deposits \\
\hline Qpcy & $\begin{array}{l}\text { Plateau Rhyolite } \\
\text { Central Plateau Member } \\
\text { West Yellowstone flow }\end{array}$ \\
\hline Qpcf & Solfatara Plateau flow \\
\hline Qpcs & Summit Lake flow \\
\hline Qpcc & Spring Creek flow \\
\hline Qpcn & Nez Perce Creek flow \\
\hline Qpcu & Spruce Creek flow \\
\hline Qpce & Elephant Back flow \\
\hline Qpं! & Tuff of Bluff Point \\
\hline Qpcm & Mary Lake flow \\
\hline Qprg & $\begin{array}{l}\text { Roaring Mountain Member } \\
\text { Gibbon River flow }\end{array}$ \\
\hline Qpm & $\begin{array}{l}\text { Mallard Lake Member } \\
\text { Mallard Lake flow }\end{array}$ \\
\hline Qpoh & $\begin{array}{l}\text { Obsidian Creek Member } \\
\text { Gibbon Hill Dome }\end{array}$ \\
\hline Qpul & $\begin{array}{l}\text { Upper Basin Member } \\
\text { Scaup Lake flow }\end{array}$ \\
\hline Qpub & Biscuit Basin flow \\
\hline Qmr & Madison River Basalt \\
\hline Qylb & $\begin{array}{l}\text { Lava Creek Tuff of Yellowstone Group } \\
\text { Member B }\end{array}$ \\
\hline Qyla & Member A \\
\hline & Mount Jackson Rhyolite \\
\hline Qmh & Mount Haynes flow \\
\hline . & $\begin{array}{l}\text { Normal fault-Dotted where concealed. } \\
\text { Bar and ball on downthrown block }\end{array}$ \\
\hline & $\begin{array}{l}\text { Lava-flow front-Hachures on } \\
\text { younger flow } \\
\text { Yellowstone Caldera }\end{array}$ \\
\hline * & Volcanic vent \\
\hline
\end{tabular}

Figure 28. Overview geologic map showing the location of field trip stops on day 2. Stops on day 2 include Hebgen Lake fault scarp and Earthquake Lake Visitor Center, Stops 1a and 1b, respectively (see fig. 1 for locations), Norris Geyser Basin (Stop 2), Tuff Cliff (Stop 3), Firehole Canyon (Stop 4) and Midway Geyser Basin (Stop 5). The main road is shown by the heavy red line. Geology by R.L. Christiansen (2001). 

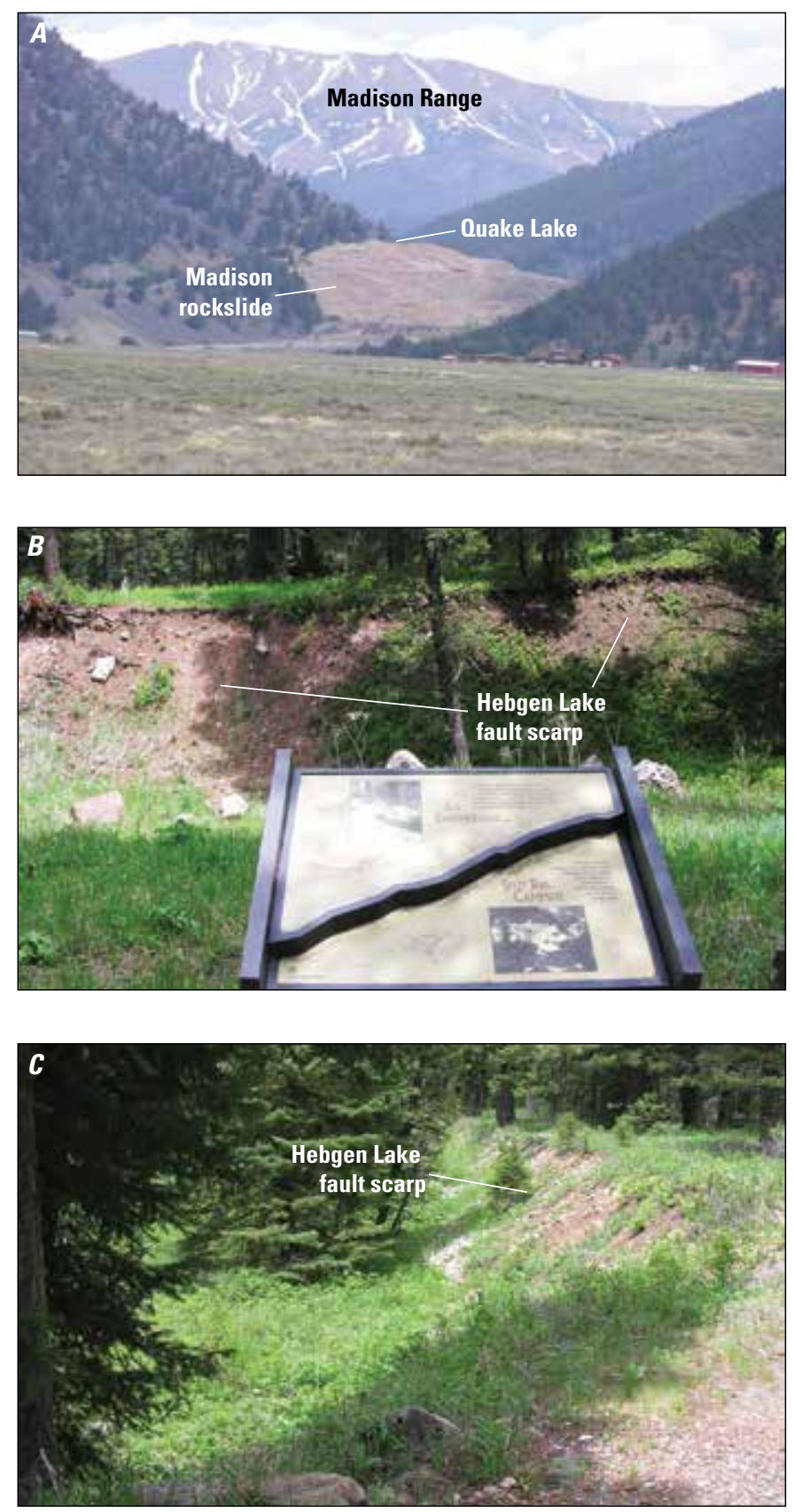

Figure 29. Photographs of the Hebgen Lake fault scarp and Madison rockslide (Stops 1a and $1 \mathrm{~b}$ ). A, View of the Madison rockslide triggered by the 1959 Hebgen Lake earthquake. The rockslide occurred on the south side of the canyon in Precambrian rocks of gneiss, schist, and dolomite. The rockslide crossed the canyon with sufficient momentum to climb the south wall to a height of 130 meters $(\mathrm{m})$ above the riverbed and dammed the Madison River to create Earthquake Lake (locally known as Quake Lake) (Morgan and others, 2008). B, View of the Hebgen Lake fault scarp at Cabin Creek. Cabin Creek is at the northwest end of the August 17, 1959, surface rupture of the Hebgen Fault. The scarp offsets two terraces of different ages; a 3- to 1-ka lower terrace that has $3.1 \mathrm{~m}$ of surface offset from the 1959 event, and an 17- to 11-ka upper terrace that is offset $5.3 \mathrm{~m}$ (Morgan and others, 2008). C, Another view of the Hebgen Lake fault scarp showing the actual displacement due to the 1959 quake. are mapped as the Lava Creek Tuff: member B close to the road and member A at slightly higher elevations. Continue east, with the Lava Creek Tuff now exposed to the south and north of the road. At mile 135, across the river you can see the vertically jointed cliffs of the Mount Haynes lava flow, a normally magnetized member of the Mount Jackson Rhyolite, a series of precaldera rhyolite lava flows erupted around the periphery of the growing magma system associated with the third-cycle caldera that formed from eruption of the Lava Creek Tuff (table 1). Along the north side of the road is a small exposure of the reversely magnetized $0.839 \pm 0.007 \mathrm{Ma}$ (Christiansen and Blank, 1972; Obradovich, 1992) Harlequin Lake Flow, an earlier phase of Mount Jackson Rhyolite volcanism (Finn and Morgan, 2002). 12.7

145.7 Turn right and turn right again immediately to go to Madison Junction rest stop. After rest stop, leave parking area and turn left and head north of Madison Junction and then east on U.S. Route 89 north toward Norris Geyser Basin. 0.8

146.5 Pass Terrace Springs, a notable thermal feature (discharge of 90 liters per second) that occurs in the collapse zone of the wall of the Yellowstone Caldera and forms a substantial terrace of travertine and silica sinter. Substantial $\mathrm{CO}_{2}$ bubbles out of the $\sim 60^{\circ} \mathrm{C}$ water. The combined discharge, as bubbles, diffuse soil flux, and bicarbonate, yields 11.4 tons per day of total $\mathrm{CO}_{2}$ (Lowenstern, Evans, and Bergfeld, 2005). 1.5

148.0 The road follows the edge of the Yellowstone Caldera (fig. 28), with extracaldera Lava Creek Tuff to the north and the intracaldera 0.148-Ma Nez Perce Creek flow (rhyolite) across the river to the south (Christiansen and others, 2007). The Nez Perce Creek flow is part of the Central Plateau Member of the postcaldera Plateau Rhyolite, filling the Yellowstone Caldera. The Gibbon River flows along the caldera contact between the younger Nez Perce Creek flow to the south and the older caldera wall exposing the Lava Creek Tuff. 2.0

150.0 The road passes Gibbon Falls, where the Gibbon River surges over vertically jointed welded Lava Creek Tuff at the fault-scarp margin of the Yellowstone Caldera. Above the falls in the cliffs to the east is the Gibbon River flow, a member of the extracaldera Roaring Mountain Member, dated at 0.118 Ma (N. Nastanski and T.L. Spell, University of Nevada, Las Vegas, unpub. data, 2004, in Christiansen and others, 2007). 5.0

155.0 The road passes through the Gibbon River Canyon (fig. 28), north of the Yellowstone Caldera, along a previously active fault, filled in to the east with the Gibbon River rhyolite lava flow. In the river bottom are numerous thermally altered areas that follow the 
linear north-south fault. Notable thermal features include Beryl Spring, Chocolate Pots, and Monument Geyser Basin. 4.0

\subsection{Turn right at Norris Junction toward Canyon Village. $\mathbf{0 . 5}$}

159.5 Turn left and head into Norris Picnic Area for lunch. After lunch, head back from the picnic area to Norris Junction. 0.5

160.0 Head straight through Norris Junction and into the Norris Geyser Basin parking lot.

\section{Stop 2. Norris Geyser Basin}

Norris Geyser Basin sits north of the Yellowstone Caldera, but represents one of the most active and dynamic thermal areas in Yellowstone National Park (White and others, 1988). Besides being located near the northern edge of the first cycle and third cycle calderas, it also sits at the south end of the Norris-Mammoth Tectonic Corridor, an active volcano-tectonic lineament with abundant volcanic vents and hydrothermal manifestations. Yellowstone's most active seismic zone sits in the region in between the Hebgen Lake Fault and Norris Geyser Basin (fig. 24). Complementary uplift and subsidence cycles between the caldera and deformation sources near Norris are inferred to signify that magma can transit between the caldera and the Norris-Mammoth Tectonic Corridor (Wicks and others, 2006). The thermal area itself is located within the Lava Creek Tuff, member B. Outside the Yellowstone Caldera margin, abundant joint sets in the tuff control the distribution of thermal features along specific azimuths, including prominent northeastsouthwest and north-south trends (Jaworowski and others, 2006). Acid-sulfate and alkaline-chloride waters are distributed widely, and commonly mix in the subsurface, creating acid chloride features, which are relatively rare elsewhere at Yellowstone (White and others, 1988; Fournier, Christiansen, and others, 1994). Examples of the varied composition of Norris waters are shown in figures 13 and 14.

Norris Geyser Basin is well known for occasional seasonal disturbances characterized by changes in spring chemistry, local increases in boiling, and changes in ground-surface temperatures (White and others, 1988). The highest subsurface temperature ever recorded in Yellowstone was $237.5^{\circ} \mathrm{C}$ at $332 \mathrm{~m}$ within the Y-12 drill hole, near Porcelain Terrace, in 1968 (White and others, 1975).

Notable thermal features include Steamboat Geyser, which creates the highest eruptive geyser plumes at Yellowstone (and the world) at 70 to $120 \mathrm{~m}$ high. Normally, however, it displays only minor eruptions where water jets 5 to $15 \mathrm{~m}$ high. Major eruptions are highly irregular with long intervals between events (White and others, 1988; Fournier, Christiansen, and others, 1994). Steamboat Geyser is thought to be relatively recent in origin, possibly only first erupting in the late 19th century (White and others, 1988). It was dormant from 1911 until 1961, but has erupted dozens of times since then, causing considerable erosion around its vent.
Steamboat's last eruption was September 3, 2014. A typical eruption begins with 3 to 40 minutes of co-erupted water and steam (fig. 30). Once the reservoir is emptied, steam continues to emerge. Typically, the forceful ejection of steam lasts less than a day, but a persistent steam cloud may last for several days (White and others, 1988). The May 23, 2004, eruption is estimated to have discharged 11,500 gallons of water (H. Heasler, former Park Geologist of Yellowstone National Park, oral commun., 2005).

Steamboat Geyser eruptions are accompanied by the complete draining of nearby Cistern Spring (fig. 31). During the fifty-year period without major eruptions of Steamboat Geyser, Cistern Spring was not active (Fournier, Christiansen, and others, 1994). In recent years, after Cistern drains in response to Steamboat Geyser eruptions, re-filling of this large pool can take several weeks. Eventually, once Cistern is re-filled and the subsurface reservoirs are pressurized, minor eruptions of Steamboat Geyser re-commence. One odd characteristic of Steamboat Geyser minor eruptions is that they may be continuous

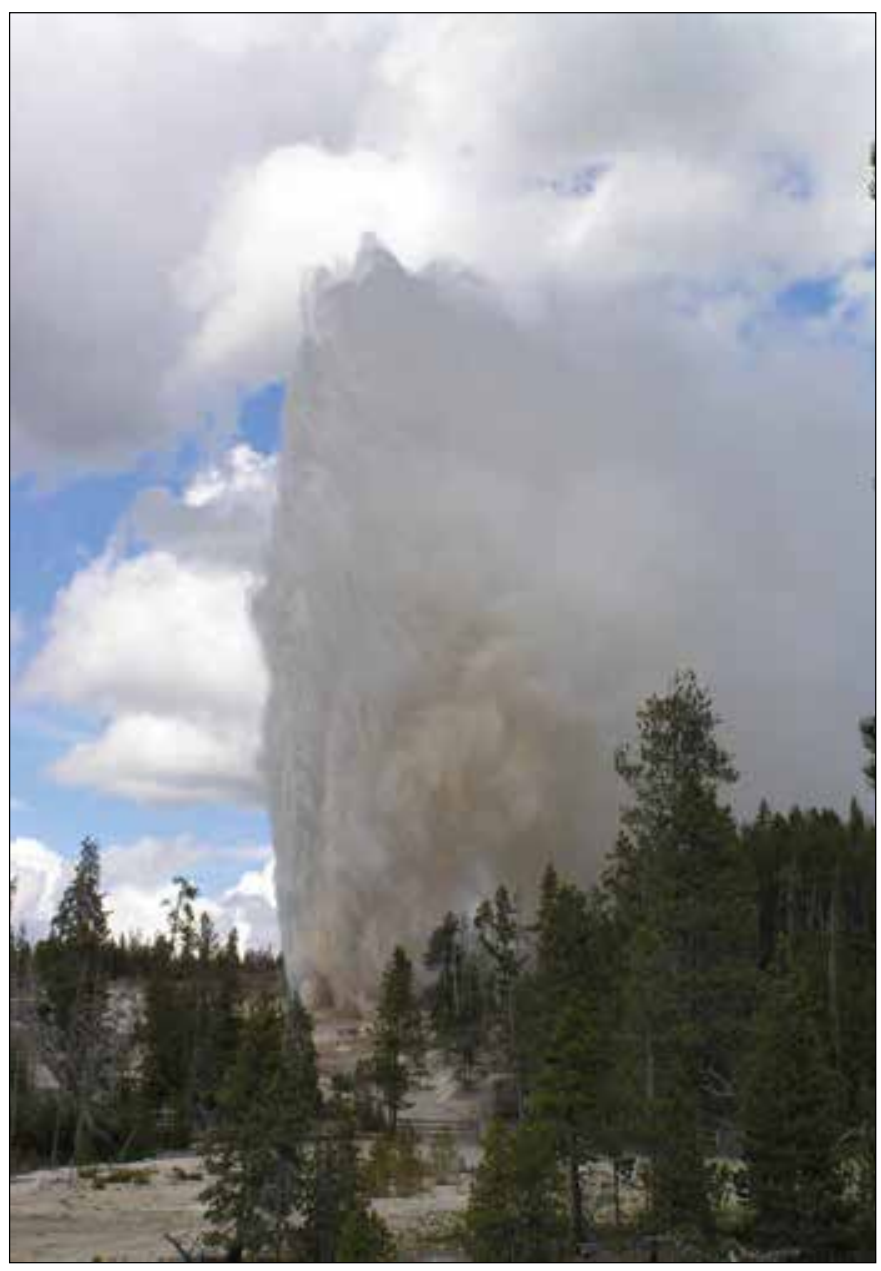

Figure 30. Photograph of the main (liquid) phase of an eruption of Steamboat Geyser in the Norris Geyser Basin on May 23, 2005 (Stop 2). Photograph from Wikipedia Commons by Hsing-Mei Wu (https:// en.wikipedia.org/wiki/Steamboat_Geyser\#/media/File:Steamboat_ Geyser_Major_Eruption_in_2005.jpg, accessed June 29, 2017). 
for four or five days at a time, but then stop entirely for a day or so. The temperature of the outlet channel for Steamboat Geyser, as well as several other features (Porkchop and Echinus Geysers, described below), are currently (2016) available at: http://volcanoes.usgs.gov/volcanoes/yellowstone/yellowstone_ monitoring_32.html.

Another well-known feature is Echinus Geyser, named for the spiny growth of its silica mineralization. The waters of Echinus Geyser are relatively low in $\mathrm{pH}$ (3.2) (table 3), making it one of the most acidic geysers in the world. For the past decade, Echinus Geyser has been minimally active as a geyser, with only a few recorded eruptions per year. In early 2005 , Clor and others (2007) recorded Echinus Geyser eruptions around every 4.5 hours, through use of temperature sensors placed in the outlet channel immediately downstream from the geyser. The pulses of water from Echinus Geyser could be detected 80 to 90 minutes later about $2 \mathrm{~km}$ downstream at the Tantalus Creek streamgage. The large seating area adjacent to Echinus Geyser reflects its popularity with visitors as an eruptive spectacle during its intermittent periods of activity.
Porkchop Geyser (fig. 32) is well known for its explosive activity in 1989, which created a $\sim 4$-m-wide explosion crater with an apron of silica sinter blocks that surround the current pool. The evolution of Porkchop Geyser from an intermittently flowing spring to its 1989 explosion was chronicled by Fournier and others (1991). They used long-term monitoring of spring chemistry and cation geothermometry to infer a 60 to $70{ }^{\circ} \mathrm{C}$ increase in the temperature of the deep water feeding the thermal feature between 1961 and 1989. The low initial temperatures were attributed to changes in hydrothermal flow caused by the $1959 \mathrm{M}_{\mathrm{w}} 7.5$ Hebgen Lake earthquake, that caused a drop in basin-wide discharge that lasted about 3 years and may have caused longer-term changes in the access of high-temperature thermal water to features like Porkchop Geyser (Fournier and others, 1991). As time passed, geothermometer temperatures increased, and in the five years prior to 1989 , Porkchop Geyser had evolved into a "perpetual spouter" with forceful venting of water and steam that was audible as far as $2 \mathrm{~km}$ from the vent (Fournier and others, 1991). After the eruption, blocks of ejected sinter were found lined with pliable, translucent botryoidal silica. Fournier and others (1991) interpreted this
Figure 31. Photographs at Stop 2 demonstrating normal conditions at the alkaline-chloride Cistern Spring, shown in $A$, versus the drained pool immediately after an eruption of nearby Steamboat Geyser, shown in $B$; the pool typically remains empty for several weeks after a major eruption.
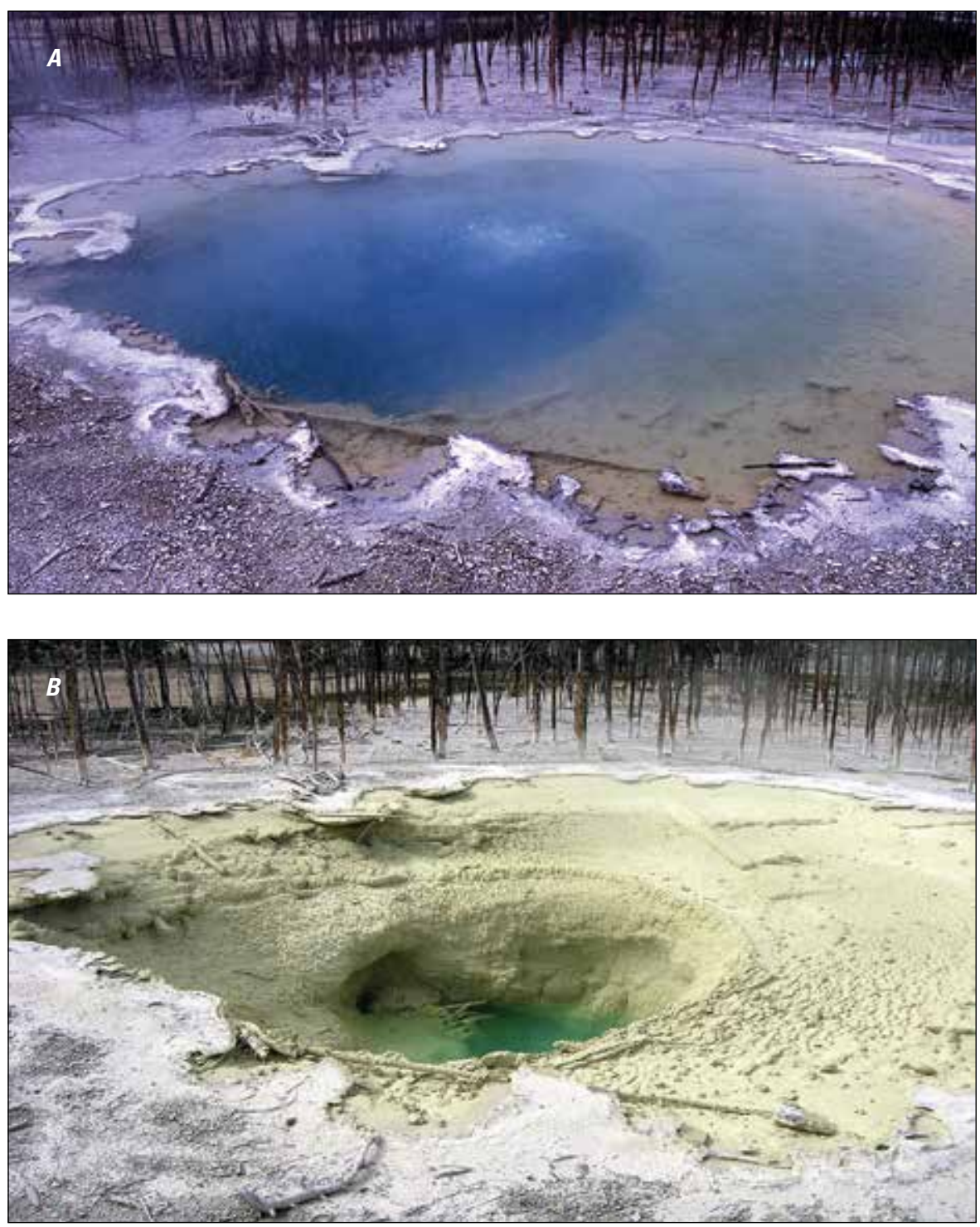


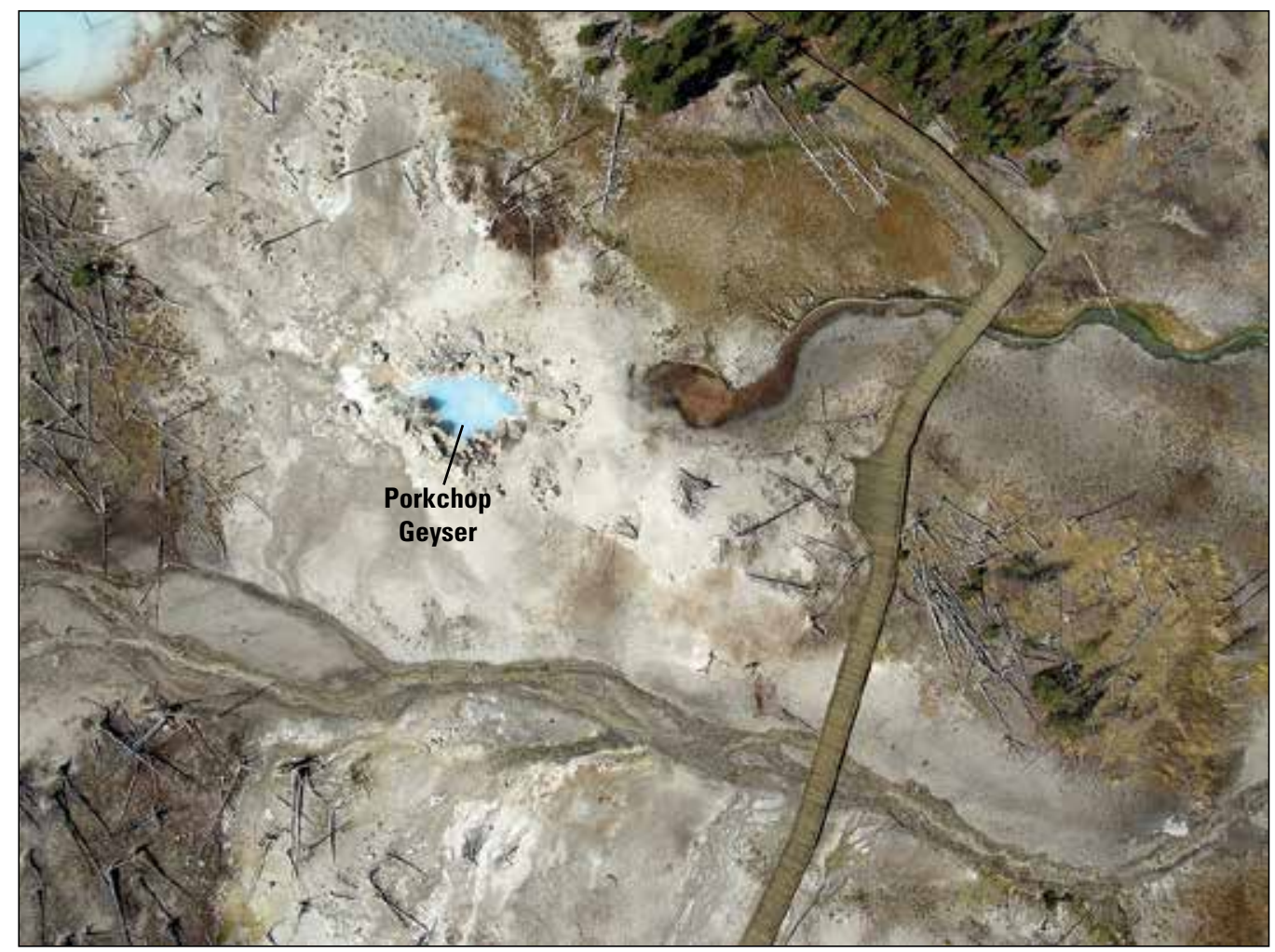

Figure 32. Aerial view of Porkchop Geyser, located in the Norris Geyser Basin (Stop 2). Large blocks of sinter ejecta are visible around the periphery of the enlarged $\sim 4$-meter-long vent area due to a relatively small 1989 hydrothermal explosion (Fournier and others, 1991). Photograph by B. Graham Wall, U.S. Geological Survey.

material to be agglomerations of silica forming a gelatinous material lining the conduit walls. Four months after the eruption, this material had become hard and brittle.

The Norris Geyser Basin is long known for its "disturbances," alternatively considered to be annual, or seasonal, but not demonstrably either. White and others (1988) listed 22 such disturbances between 1926 and 1984. Since then, fewer examples have been identified, though it is not clear whether this is due to less careful surveillance from fewer long-term naturalists who catalogue such activity. It is clear, though, that periodic changes, interpreted as subsurface, basin-wide "geyser eruptions" cause significant changes in the degree of boiling and chemical mixing in thermal features throughout Norris Geyser Basin (White and others, 1988; Fournier and others, 2002). In 2003, a disturbance was inferred based on anomalous behavior in numerous thermal features in the Back Basin, including (1) reduced outflow of water, (2) increased evidence of boiling, (3) changes in ground surface temperatures, and (4) changes in the interval of eruptions at Echinus Geyser (Lowenstern and others, 2003). Much of the present boardwalk in the western Back Basin was re-routed as a result of the hydrothermal activity during the summer and fall of 2003.

In response to the 2003 disturbance, a small network of seismometers and GPS receivers was deployed by R.B. Smith of the University of Utah, with collaborators at Yellowstone National Park, the U.S. Geological Survey, Incorporated Research Institutions for Seismology (IRIS), and UNAVCO (http://volcanoes.usgs.gov/volcanoes/yellowstone/yellowstone monitoring_49.html). Dawson and others (2012) discovered that shallow hydrothermal tremors were related to cavitation of steam bubbles in liquid water beneath the basin. Tiny tremor signals correlated with daily temperature variations and pool temperatures (the latter two being inversely correlated). In contrast, no actual earthquakes were detected near Norris Geyser Basin. As concluded by Fournier and others (2002), it appears that much of the activity related to the disturbances is due to hydrologic response to annual recharge patterns and tectonic stresses. Regarding the latter, Wicks and others (2006) linked the 2003 disturbance and other activity in the Norris-Mammoth Tectonic Corridor to regional dilatation associated with the 1996 to 2003 uplift of the northern Yellowstone Caldera.

160.0 Leave Norris. Take right turn onto U.S. Route 89 South. On the right (west) side of the road, we will pass the trailhead to Monument Geyser Basin and, farther south, Beryl Hot Springs.

Monument Geyser Basin is located on a ridgetop along a northwest-trending fault and is comprised of intensely altered 0.631-Ma Lava Creek Tuff (Morgan and others, 2007b; Matthews and others, 2015). Monument Basin is unusual due to the siliceous sinter deposits there that occur as "monuments" or structures, similar to the siliceous spires discovered in 1997 and recovered from Bridge Bay in 1999 on the floor of Yellowstone Lake (Morgan and others, 2003; 2007b). Currently, Monument Geyser Basin sits about $250 \mathrm{~m}$ above the water table and emits highly acidic steam that is consistent with the intense alteration of the host rock (Lava Creek Tuff). It is unlikely these monuments formed from an acid-steam system because steam has a very limited capacity for carrying $\mathrm{SiO}_{2}$. We suggest these deposits formed from a hot water system, probably 
related to a glacially dammed lake during the waning stages of the Pinedale glaciation about 15,000 to 12,000 years ago.

In contrast to the high acidity at Monument Hot Springs, Beryl Spring, located at the base of the hill and along the same northwest-trending fault system as Monument Geyser Basin, issues alkaline-chloride water. It is one of a few thermal vents in Yellowstone that precipitates significant gold $(\mathrm{Au})$ in its sinter (1.4 parts per million [ppm]) (Fournier, Kennedy, and others, 1994).

Thermal fluids and gases of the Gibbon River Canyon have high ${ }^{3} \mathrm{He} /{ }^{4} \mathrm{He}$ ratios $(10-12 \mathrm{Ra})$, having the second highest helium isotope ratios in the park, after Mud Volcano (Kennedy and others, 1985; Lowenstern and others, 2015). 10.9

170.9 We will stop at a pull-off to look west toward Tuff Cliff and to note (1) the topographic margin of the Yellowstone Caldera defined by the contact between precaldera Mount Haynes flow, (2) the postcaldera West Yellowstone flow, (3) scarps related to collapse of the Yellowstone Caldera as seen in Tuff Cliff and Secret Valley to the north, and (4) the outflow facies of the Lava Creek Tuff (fig. 33). 1.0

Turn into the Tuff Cliff parking lot on the right.

\section{Stop 3. Tuff Cliff}

Tuff Cliff is a massive 200-m-thick exposure of Lava Creek Tuff, member A (fig. 33). Much of the lower part of the cliff consists of non-welded to incipiently welded ignimbrite. Columnar joints of densely welded ignimbrite can be seen high up on the cliff. The white-to-light-gray coloration of the Lava Creek Tuff has experienced vapor-phase alteration by water and other gases trapped in the tuff and released during degassing and devitrification. Tuff Cliff represents a portion of the caldera wall that collapsed immediately after emplacement of the Lava Creek Tuff while the ignimbrite was hot, crystallizing, and welding. $\mathbf{1 . 8}$

173.7 Continue straight at Madison Junction toward Old Faithful. South of the Madison Junction rest stop (and west [right] of the road at the bridge), the Gibbon River meets the Firehole River to form the Madison River. 0.4

174.1 Turn right onto Firehole Canyon Drive. Follow the road along Firehole River at the contact between two postcaldera Central Plateau Member rhyolitic lava flows: the 0.148-Ma Nez Perce Creek flow and the 0.114-Ma West Yellowstone flow. 1.4

\section{Stop 4. Firehole Canyon}

175.5 Drive along the west edge of the Nez Perce Creek flow; the western side of the road parallels the Firehole River. To the immediate west, vertically jointed, flow banded, brecciated flow fronts of the younger west Yellowstone flow are well exposed. We will stop at several pull-offs to examine some of the features associated with both rhyolitic lava flows (fig. 34). 0.5

176.0 At the intersection of Firehole Canyon Drive and the Grand Loop Road (U.S. Route 89 South), turn right toward Old Faithful. Note the contact and flow fronts of the Nez Perce Creek flow to the east and the West Yellowstone flow to the west. $\mathbf{1 . 7}$

177.7 As we continue south, the area opens up into the Lower Geyser Basin, so named because it is downstream along the north-flowing Firehole River from the Upper Geyser Basin in the Old Faithful area. The Lower Geyser Basin is rimmed by vertical cliffs of postcaldera rhyolitic lava flows including the West Yellowstone flow to the north, west, and south, the Nez Perce Creek and Elephant Back flows to the east, and small outcrops of early volcanism associated with the Mallard Lake resurgent dome.

Near the northern part of Lower Geyser Basin is Pocket Basin, a large hydrothermal explosion crater described first in detail by Muffler and others (1971). Pocket Basin (figs. 12, 28) is in the broad, flat alluvial valley of the Firehole River $\sim 4 \mathrm{~km}$ northeast of Twin Buttes (fig. 33). It forms an elongate, northeast-trending, flat-bottomed crater associated with a well-defined breccia deposit that forms its rim; the rim has been breached on its southwest margin by the Firehole River (Muffler and others, 1971). The crater is $\sim 300 \mathrm{~m}$ wide by $500 \mathrm{~m}$ long and the ejecta rim rises in most places $\sim 10 \mathrm{~m}$ above the floor of Pocket Basin; a maximum relief crater wall is $\sim 20 \mathrm{~m}$ on the east side. The floor of the crater is at about the same elevation as that of the surrounding floodplain and contains abundant hot springs, diatomaceous sediment, and modern sinter deposits, especially in its southeast part.

Clasts of Pocket Basin explosion breccia, collected from deposits on the crater rim around the basin include chalcedony; chalcedonic breccia; and silicified, fine-grained, laminated mudstone and siltstone (lake deposits). Other explosion breccia clasts include quartzcemented sandstone and occasional fragments of wellcrystallized quartz veins as thick as $4 \mathrm{~cm}$ with euhedral crystals growing inward toward vein clusters. Many fragments are stained orange, and some contain angular, orange-stained cavities up to $1 \mathrm{~cm}$ long that often contain 


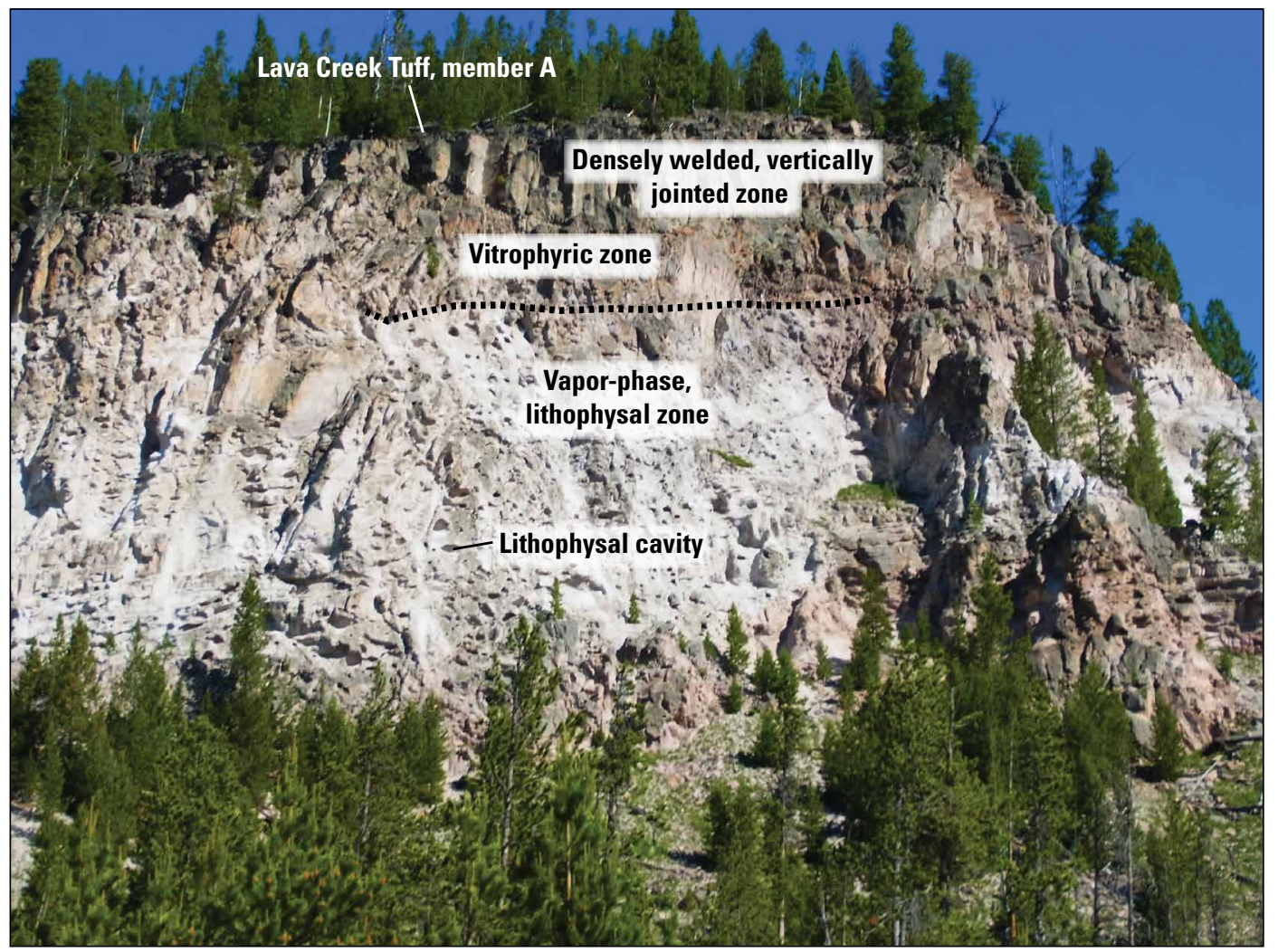

Figure 33. Photograph at Tuff Cliff (Stop 3) showing characteristic zones within the Lava Creek Tuff of Yellowstone Group, member $A$, including an extensive vapor-phase zone containing abundant lithophysal cavities capped by a vitrophyric zone that is strongly jointed. A dashed black line marks the general contact between these two zones. The view of the photograph is to the north.
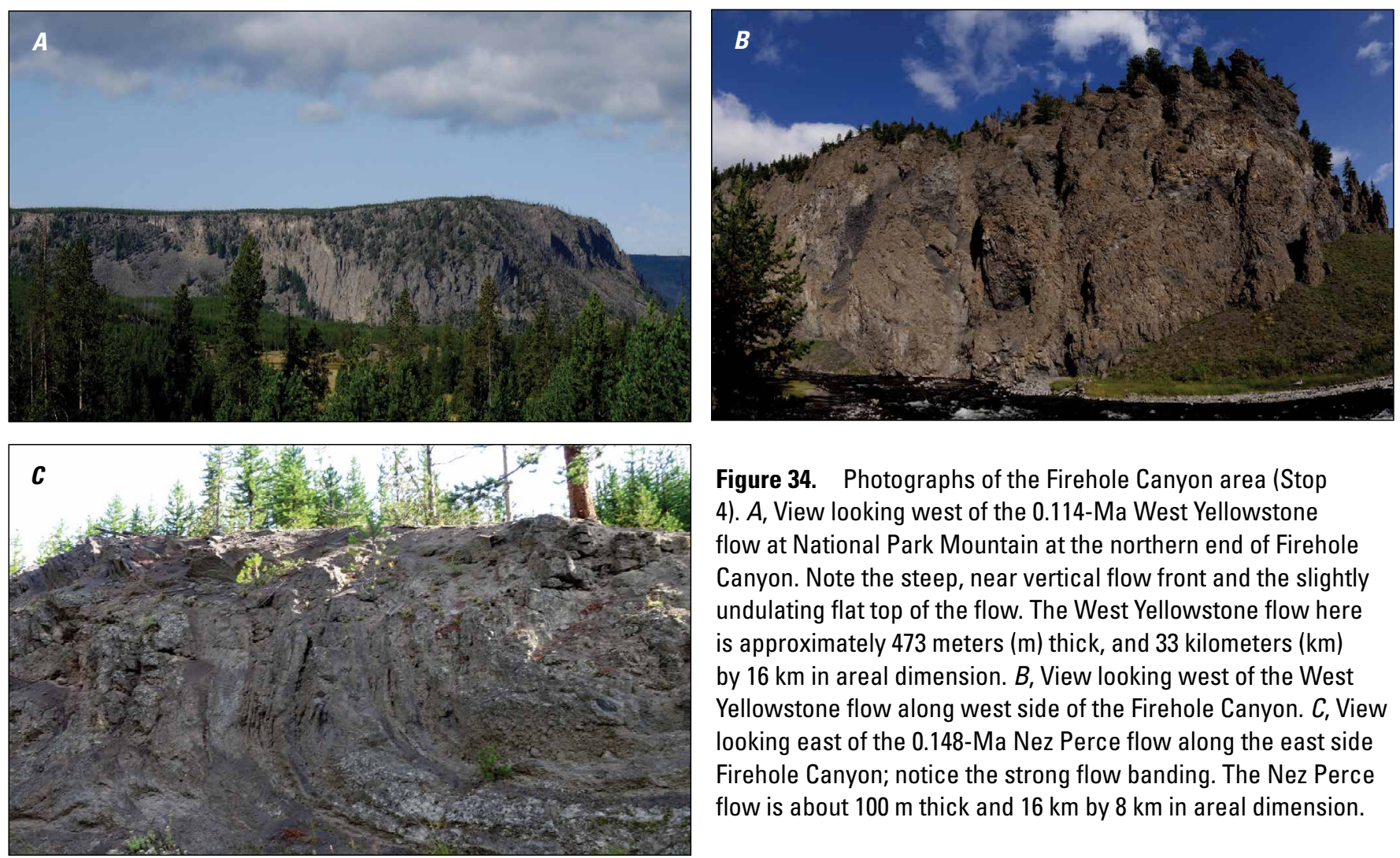

Figure 34. Photographs of the Firehole Canyon area (Stop 4). $A$, View looking west of the 0.114-Ma West Yellowstone flow at National Park Mountain at the northern end of Firehole Canyon. Note the steep, near vertical flow front and the slightly undulating flat top of the flow. The West Yellowstone flow here is approximately 473 meters $(\mathrm{m})$ thick, and 33 kilometers $(\mathrm{km})$ by $16 \mathrm{~km}$ in areal dimension. $B$, View looking west of the West Yellowstone flow along west side of the Firehole Canyon. $C$, View looking east of the 0.148-Ma Nez Perce flow along the east side Firehole Canyon; notice the strong flow banding. The Nez Perce flow is about $100 \mathrm{~m}$ thick and $16 \mathrm{~km}$ by $8 \mathrm{~km}$ in areal dimension. 
powdery iron-sulfate formed from oxidation of pyrite $\left(\mathrm{FeS}_{2}\right)$ or other sulfides. Primary volcanic rock clasts have not been found in the explosion breccia; however, Muffler and others (1971) report occasional rounded rhyolitic fragments that were probably derived from underlying alluvial or glacial deposits.

Cores from the Fountain Flats Bridge area (that contain fragments of Pinedale Lake sediment and possibly older, silicified lake sediment at greater depth) (fig. 28) suggest a sizeable lake in the area at the end of Pinedale glaciation (Muffler and others, 1982; Pierce, 1979). Muffler and others (1971) argued that Pocket Basin exploded during the waning stages of Pinedale glaciation and was triggered by the sudden pressure decrease that accompanied rapid drainage of an ice-dammed lake. This explanation is plausible and is consistent with field evidence, but the lack of geochronology data for the explosion breccia deposit at Pocket Basin leaves uncertainty about timing and mechanism (Morgan and others, 2009). 5.8

182.0 As we drive south into the valley, postcaldera rhyolitic lava flows are exposed on either side of the main road and create the hummocky topography of topographically high, steep-sided hills with undulating hilltops. To the west is the 0.114-Ma West Yellowstone flow and to the east are exposures of the 0.148-Ma Nez Perce Creek flow and, farther south, the 0.153-Ma Elephant Back flow (table 1). As discussed in Morgan and Shanks (2005), the low permeability of the postcaldera rhyolites has a profound influence on the location of later hydrothermal features. The valley is filled with various sediment types, including lacustrine, fluvial, and glacial sediments.

Hydrothermal activity was focused at the edges of the high-silica rhyolitic lava flows and introduced ascending hydrothermal fluids enriched in silica into these valley-filled sediments. During glaciation, ice melted over hydrothermally active sites, such as at Twin Buttes, Porcupine Hills, and Pocket Basin, contributing additional fluids and glacial debris to the hydrothermal system that eventually became silicified and resistant. To the east, near the road, are the Porcupine Hills and to the west-southwest, across the Lower Geyser Basin, are Twin Buttes (figs. 12, 28). Both sets of hills are thermal kames, formed of poorly sorted, hydrothemally cemented Pleistocene glacial sediments deposited by localized melting of ice above a thermal area and later cemented to form resistant lower hills in the valley. Zeolites and a variety of clay minerals are found that normally form at temperatures much higher than are currently found at the surface. Temperatures were elevated relative to current conditions because the boiling temperature is much higher at pressures found beneath thousands of feet of glacial ice. Fluid inclusions in minerals sampled from geothermal drill holes confirm that downhole temperatures in many geothermal reservoirs at Yellowstone were 10 to $50^{\circ} \mathrm{C}$ higher during glacial periods (Bargar and Fournier, 1988).

Twin Buttes is a complex of thermal kames with hydrothermal explosion craters near the top. Resistant ice-contact deposits stand high along the northwest margin of the main explosion crater rim. The central part of Twin Buttes contains several nested explosion craters in a depression that is $\sim 500$ to $600 \mathrm{~m}$ in aerial dimensions (Morgan and others, 2009). Six of the craters are filled by lakes that are perched $\sim 80 \mathrm{~m}$ above the elevation of the nearby Firehole River floodplain. Hydrothermal explosion breccia deposits have been mapped (Christiansen, 2001) along the south and east rims of the explosion crater area and extend $\sim 1 \mathrm{~km}$ to the northeast as a breccia lobe that may represent a directed blast. Hydrothermal explosion breccia from the Twin Buttes crater includes a variety of silicified sandstone and conglomerate (Muffler and others, 1971); many of the fragments are cemented by opal and zeolite minerals and presumably were derived from the hydrothermally cemented ice-contact deposits that underlie the buttes. Rhyolite fragments identified as clasts in the breccia deposit are likely derived from nearby rhyolitic lava flows inferred in the shallow subsurface (Morgan and others, 2009). 1.2

\section{Stop 5. Midway Geyser Basin}

183.2 Follow the bridge across the Firehole River to the Midway Geyser Basin, where the geysers and hot springs are the slightly alkaline, chloride-rich variety typical of deep-seated hot fluids hosted in rhyolitic terranes within the Yellowstone Caldera. Here, Excelsior Geyser Crater (fig. 35) discharges about 15,200 liters ( 4,000 gallons) of boiling water per minute that flow into the river near the walking path. Cooling and evaporation of hydrothermal waters causes deposition of chalcedonic silica as sinter terraces that extend all the way to the river. Excelsior Geyser erupted in a series of violent explosions in the 1880s (Norris, 1881) and 1890s (Allen and Day, 1935). Rocks were dislodged and thrown more than 100 meters into the air, providing quite a spectacle for early visitors to the park. Other than a short period of geyser activity in 1985, the Excelsior Geyser has since remained quiet (Lowenstern, Christiansen, and others, 2005).

The Grand Prismatic Spring is the largest hot spring in the United States, and the third largest in the world (the largest are in New Zealand and the Dominican Republic). It is $113 \mathrm{~m}$ in diameter and is more than $37 \mathrm{~m}$ deep in its central vent area. The spring was named by the Hayden Expedition in 1871 after the striking prismatic colors that grade from the clear blue boiling waters in its center to lower-temperature bands around its margins. Fluid temperatures range from $87^{\circ} \mathrm{C}$ near the central vent to 


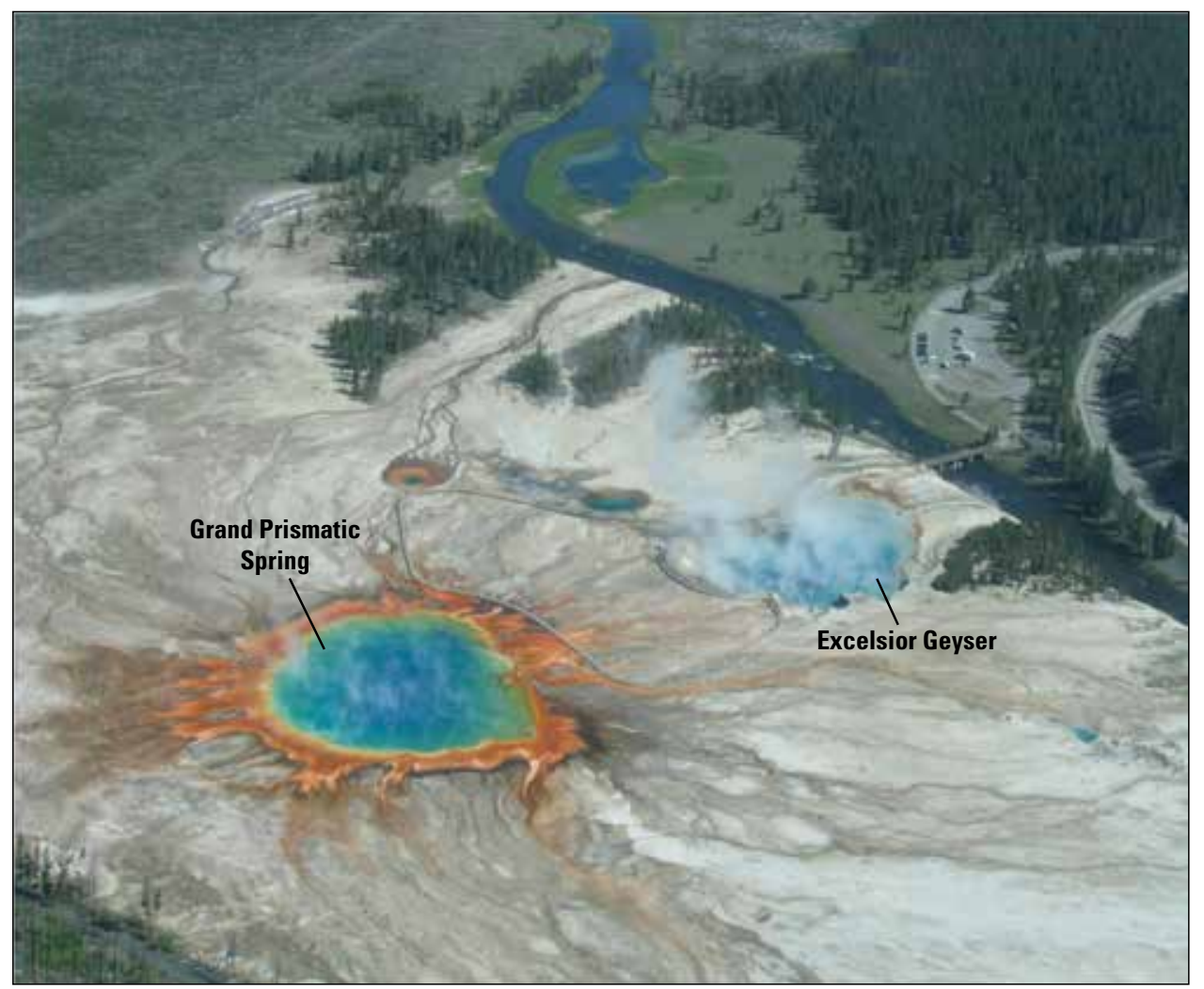

Figure 35. Oblique overhead image of Grand Prismatic Spring and Excelsior Geyser in the Midway Geyser Basin (Stop 5). Excelsior Geyser crater formed by hydrothermal explosions, mainly in the 1880s, and outflow from Excelsior exceeds 250 liters per second, which is the largest hot spring discharge in Yellowstone National Park. Grand Prismatic Spring is the largest, and many would argue most scenic, hot spring pool ( 105 meters in diameter by $\sim 37$ meters deep) in North America and is the third largest in the world. Photograph by Ken McGee, U.S. Geological Survey.

$63{ }^{\circ} \mathrm{C}$ on the margin of the pool. Only chemosynthetic hypothermophilic bacteria or archea can live near the vent. As the fluids cool near the margins, photosynthetic themophilic bacteria in the cyanobacteria group provide the bright orange, red, yellow, and green colors.

Return to cars. Proceed south on main road (U.S. Route 89) to Old Faithful in the Upper Geyser Basin. 6.0

189.2 Arrive at the Old Faithful area, Upper Geyser Basin. Tonight and tomorrow we will stay in the Old Faithful area cabins. Dinner is on your own; food is available at several locations in the general Old Faithful/Snow Lodge area.

\section{Day 3: Old Faithful to Pitchstone Plateau and West Thumb Geyser Basin with Return to Old Faithful (Fig. 36)}

0.0 Turn left onto Grand Loop Road toward West Thumb Geyser Basin from the Old Faithful area. Drive southeast toward Craig Pass. Leave the Old Faithful area at 7:30 a.m.

As we head east from Old Faithful (fig. 36), we rise out of the Upper Geyser Basin up onto the Mallard Lake resurgent dome of the third-cycle Yellowstone Caldera. At Mallard Lake Dome, a series of rhyolitic lava flows were emplaced beginning with eruption of the $0.516 \pm 0.007-\mathrm{Ma}$ Biscuit Basin flow (Gansecki and others, 1996), followed by eruption of the $0.257 \pm 0.013-\mathrm{Ma}$ (A. Calvert, unpub. data, 2005, in Christiansen and others, 2007) Scaup Lake flow, and later by eruption of the $0.164 \pm 0.014$-Ma Mallard Lake rhyolite flow (Christiansen and others, 2007). Our route passes through the latter two units on the resurgent dome. As we start gaining elevation on the dome, note the extensive hydrothermal alteration associated with the bright gold, red, orange, and white coloration of the Scaup Lake flow exposed on the north side of the road. 6.1

6.1 The road passes the contact between the older, more hydrothermally altered Scaup Lake flow to the west and the younger Mallard Lake flow, exposed farther east and on the north side of the road. Look north and northwest on the dome to see the surficial expression of mapped rectilinear faults in the Mallard Lake flow. As we drive east, the road follows the contact of the Mallard Lake flow to the north (on the Mallard Lake resurgent dome) and, to the south, the Spring Creek flow, another postcaldera rhyolite flow that erupted at about $\sim 0.145 \mathrm{Ma}$ (Christiansen and others, 2007).

Continue east crossing the DeLacy Creek drainage which flows into Shoshone Lake. Look south for views into Shoshone Lake as we continue east and rise from that drainage. $\mathbf{1 . 7}$ 

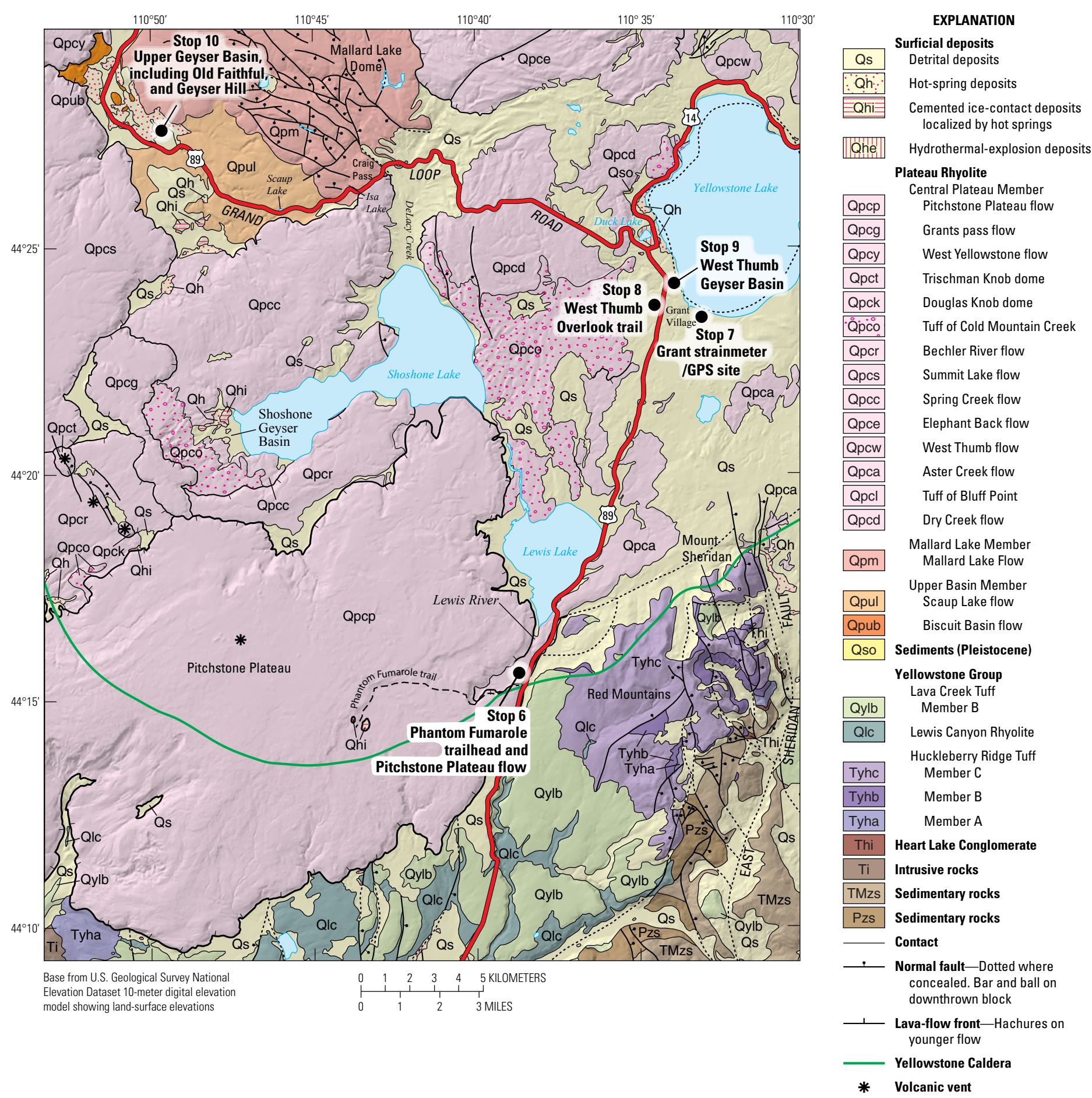

Figure 36. Geologic map and field trip stops on day 3. Stops include Phantom Fumarole trailhead and Pitchstone Plateau flow (Stop 6), Grant strainmeter/GPS site (Stop 7), West Thumb Overlook trail (Stop 8), West Thumb Geyser Basin (Stop 9), and Upper Geyser Basin, including Old Faithful and Geyser Hill (Stop 10). Note the full areal extent of the Pitchstone Plateau lava flow at Stop 6. The main road is shown by the heavy red line. Geology by R.L. Christiansen (2001). 
7.8 Near Craig Pass, Isa Lake sits atop the Continental Divide. The lake has two outlets, and surprisingly, the east outlet drains to the Pacific Ocean, via the Snake River and Columbia River systems. The west outlet, in turn, feeds the Firehole River, and ultimately ends up delivering water to the Gulf of Mexico through the Missouri and Mississippi River systems.

Continue east up onto the $0.166-$ Ma Dry Creek flow. As we descend into the Yellowstone Lake basin, look east for views of Duck Lake (a 500-m-wide hydrothermal explosion crater; fig. 37), West Thumb Caldera (a 6-km by $8-\mathrm{km}$-wide structure associated with eruption of the tuff of Bluff Point), and Yellowstone Lake at the base of the Absaroka Range (the eastern topographic margin of the Yellowstone Caldera) (figs. 1, 37). Look south to the Red Mountains and views of Mount Sheridan and Flat Mountain (fig. 1), where the margins of both the first- and third-cycle calderas coincide. The 0.631-Ma Lava Creek Tuff member B is on the flanks of Mount Sheridan more than $900 \mathrm{~m}$ above the down-dropped and adjacent Heart Lake block to the east along the active East Sheridan fault (eastern edge of figs. 2, 36). The rate of uplift along this fault is comparable to that for the Teton Fault (fig. 2) to the south $(\sim 1,250$ meters per million years) (Pierce and Morgan, 1992).

On a clear day from the north shore of West Thumb Basin, one can see the Teton Range far to the south. The Teton Range (fig. 2) is a fault-bounded mountain range that has developed over the past 4 to 10 million years. The spectacular topography and scenery of one of North America's youngest mountain ranges are a result of rapid uplift along a system of faults present at the base of the eastern mountain front. Uplift rates over the past 5 million years are as great as 1,250 meters per million years, making the Tetons one of the fastest rising ranges in North America (Pierce and Morgan, 1992). The distribution of the outflow facies of the 4.45-Ma Kilgore Tuff, erupted from the Kilgore Caldera on the eastern Snake River Plain, indicates that the northern Teton Range was not a significant topographic feature at this time and suggests an even higher rate of uplift in the northern block (Morgan and McIntosh, 2005). 9.9

\subsection{Continue straight south on U.S. Route 89 to Lewis} Falls, passing the turn-off on the left for West Thumb Geyser Basin. 11.1

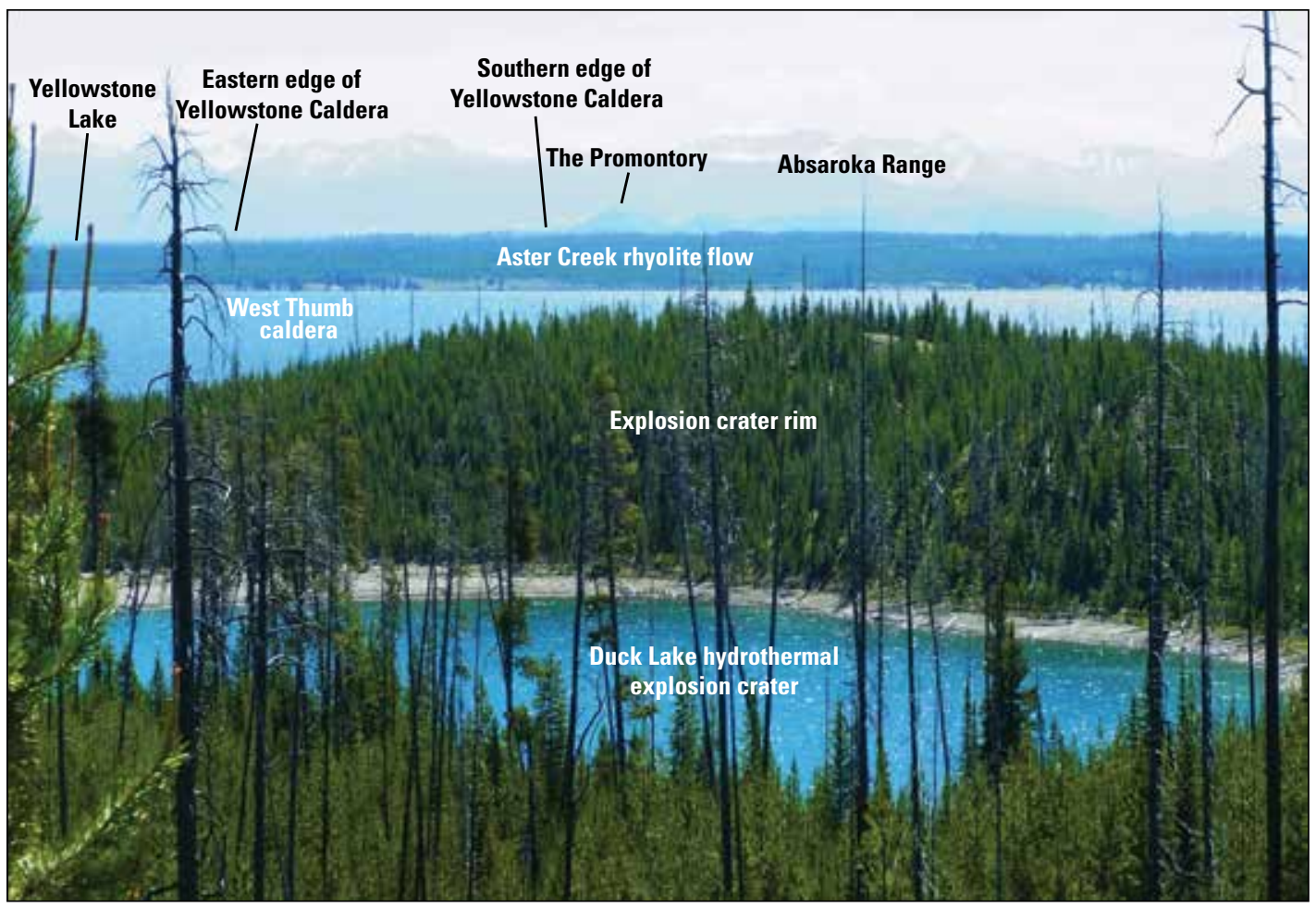

Figure 37. View on day 3 looking east from Grand Loop Road immediately west of Duck Lake. Duck Lake is a 6- to 4-ka hydrothermal explosion crater surrounded by a rim of explosion breccia. East of Duck Lake is the West Thumb Caldera and the $0.155-\mathrm{Ma}$ Aster Creek rhyolite flow. To the east of the Aster Creek flow is the main body of Yellowstone Lake. On the eastern edge of Yellowstone Lake and at the base of the Absaroka Range is the eastern topographic margin of the Yellowstone Caldera. The Promontory, which separates the Southeast Arm from the South Arm of the lake, also can be seen low in the background to the east of the Aster Creek flow. The Promontory is composed of Tertiary pre-Yellowstone volcanic rocks; directly north of the Promontory is the southern topographic margin of the Yellowstone Caldera. Abbreviations: ka, kilo-annum (thousand years before present); $M a$, mega-annum (million years before present). 
28.8 As we cross the bridge across the Lewis River, look west up the Lewis River to Lewis Falls where the river is incising along the contact between the younger Pitchstone Plateau flow, higher and exposed to the west and south, and the older Aster Creek flow exposed to the north and east. Continue south on U.S. Route 89 to the parking area on west side of the road associated with the Phantom Fumarole trailhead (fig. 36). 2.0

30.8 Arrive at the Phantom Fumarole trailhead. We will hike up this trail $\sim 2.0 \mathrm{mi}(\sim 3.2 \mathrm{~km})$ round trip to exposures along the Phantom Fumarole trail ascending the flow front of the Pitchstone Plateau lava flow and to exposures near its cap (fig. 36).

\section{Stop 6. Phantom Fumarole Trailhead and Pitchstone Plateau Flow}

The rhyolitic lava flows within the Yellowstone Caldera, known as the Central Plateau Member of the Plateau Rhyolite (Christiansen, 2001), are very large and thick. Individual flows exceed $30 \mathrm{~km}$ in maximum areal dimension. Characteristic lavaflow morphologies include lobate forms, near-vertical margins (some as high as $300 \mathrm{~m}$ ), rubbly vitric flow carapaces, hummocky or ridged tops, and strongly jointed interiors. Stream drainages tend to occur along flow boundaries, rather than within flow interiors (Christiansen and Blank, 1972; U.S. Geological Survey, 1972b; Christiansen, 2001; Morgan and Shanks, 2005).

The $0.0749 \pm 0.0034-\mathrm{Ma}$ Pitchstone Plateau flow (table 1, fig. 36) is an excellent example of a postcaldera lava flow and also is one of the largest measured $(30.5 \mathrm{~km}$ long by $16 \mathrm{~km}$ wide, $>300 \mathrm{~m}$ thick) lava flows in Yellowstone. Christiansen (2001) infers the vent area to be in the north-central part of the flow (fig. 36), where the flow is thickest.

The trailhead starts from near the edge of the Pitchstone Plateau flow and climbs along switchbacks in the flow front to near the flow top. To the east, the Red Mountains are in the foreground with Mount Sheridan at the high point (3,147 m; $10,315 \mathrm{ft}$ ). The Red Mountains sit astride a major extracaldera, north-south tectonic zone and consist of Huckleberry Ridge Tuff with extensive exposures of the Lava Creek Tuff on the lower flanks of the mountains. Heart Lake Geyser Basin (fig. 12), north of the Red Mountains and west of Heart Lake, issues along a series of north-south-trending normal faults known as the East Sheridan Fault (fig. 2) and the southern margin of the Yellowstone Caldera.

The Pitchstone Plateau flow provides an outstanding opportunity to examine a young high-silica rhyolite lava flow edge and carapace. Many outcrops show vitrophyric exterior flow rinds with shrinkage cracks and sheet-jointed crystallized interior zones. Vapor-phase spherulitic and lithophysal zones commonly include large cavities. Befus (2016) estimated that spherulites grow through devitrification of the post-eruption obsidian at temperatures as high as $\sim 580{ }^{\circ} \mathrm{C}$ and cease growing at about $300^{\circ} \mathrm{C}$. Abundant perlitic zones are related to devitrification.
Flow banding and brecciation occur locally. Thermally oxidized red glass is common in the Pitchstone Plateau flow, sometimes alternating with black glass in flow-banded rocks.

Return to the cars and head back north to West Thumb. 11.4

\subsection{Turn right into Grant Village. 0.9}

43.1 Turn right on the road across from the service station. $\mathbf{0 . 7}$

43.8 Stop along the edge of the road and walk out to the Grant strainmeter/GPS site.

\section{Stop 7. Grant Strainmeter/GPS Site}

Here we observe the Grant strainmeter/GPS site (fig. 36). The borehole here is one of six boreholes drilled in Yellowstone by the Plate Boundary Observatory (the geodetic component of the National Science Foundation [NSF] funded EarthScope project). The boreholes range in depth from around $361 \mathrm{ft}(110 \mathrm{~m})$ to almost $800 \mathrm{ft}(240 \mathrm{~m})$. Five of the six boreholes contain strainmeters and all six contain seismometers and tiltmeters, as well as full meteorological instrumentation. These are some of the many instruments used in the larger Yellowstone seismic/geodetic monitoring network. This network is used to monitor the Yellowstone caldera for seismic and deformation signals related to the volcanic system. These networks are, for the most part, operated by the University of Utah and the Plate Boundary Observatory where data are analyzed and disseminated in near-real time. Data from this strainmeter helped scientists discover that Yellowstone Lake has frequent seiche waves (fig. 38; Luttrell and others, 2013).

The borehole, B944, was the second one drilled by the Plate Boundary Observatory in the Grant area. The first, known as Grant 1, was located about $0.5 \mathrm{~km}$ west of the Grand Loop Road at a similar latitude to B944. That hole was anomalously hot, with a bottom-hole temperature of $92.0^{\circ} \mathrm{C}$ at 206 feet $(63.4 \mathrm{~m})$ depth and was not suitable for instrumentation (Jaworowski and others, 2016). The B944 well penetrated to 505 feet (154 m) through a sequence of shallow sediments and underlying lavas and tuffs associated with formation of the West Thumb Caldera (Jaworowski and others, 2016). The bottom-hole temperature in B944 was $34.8^{\circ} \mathrm{C}$, much cooler than that at Grant 1. At B944, considerable water flow was evident at the bottom hole, exceeding 300 gallons per minute ( $\sim 19$ liters per second).

Proceed back to the main road, turning left. 1.6

45.4 Turn right (north) on U.S. Route 89. 1.5

46.9 Park on the west side of U.S. Route 89 just south of the intersection with Grand Loop Road. There are pullouts for the trailhead just south of a marked crosswalk. Bring lunches and head out on West Thumb Overlook trail (west of road). 
$\boldsymbol{A}$

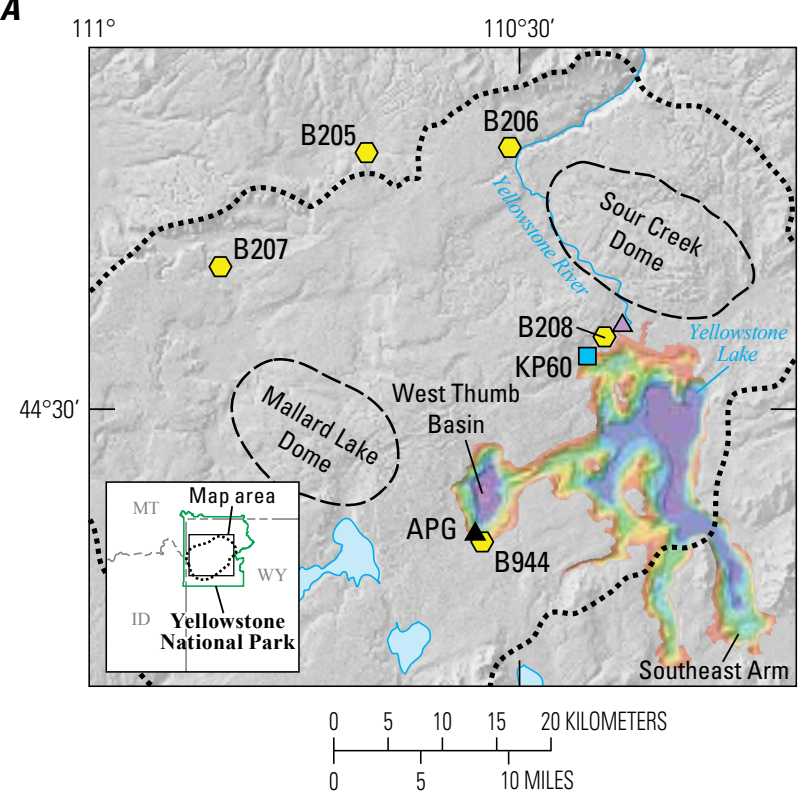

B

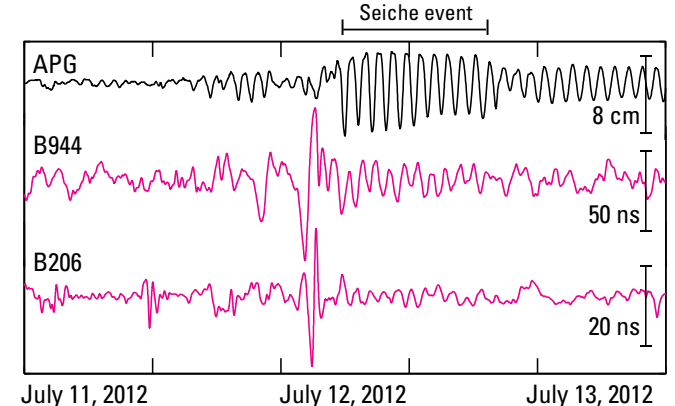

C
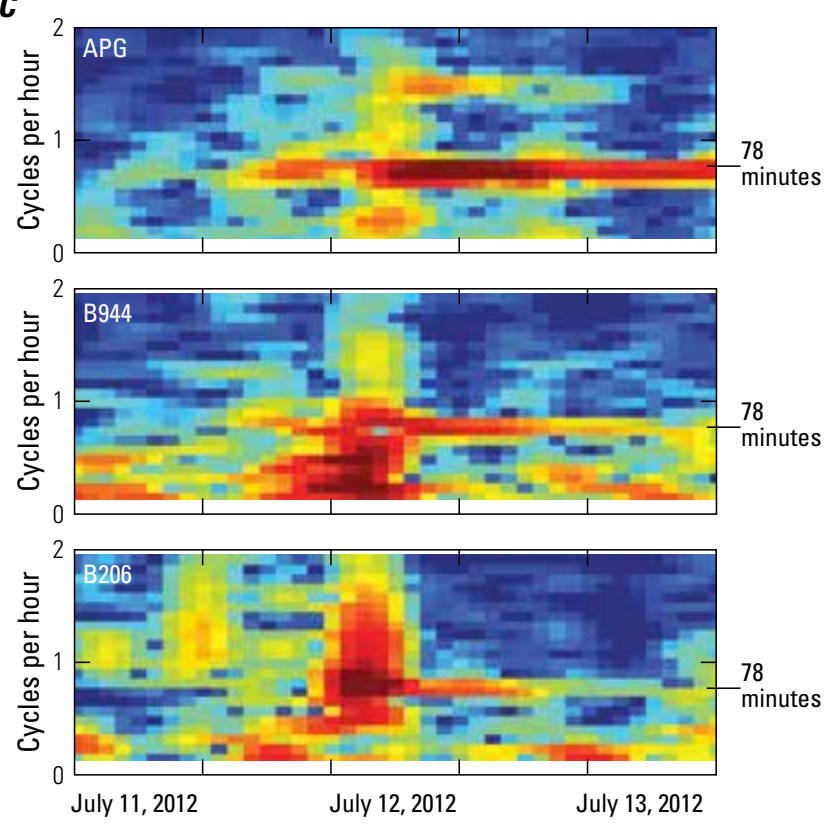

\section{EXPLANATION}

Depth in meters

0

10

20

30

40

50

60

70

80

90

100

110

○ Borehole strainmeter

$\square \quad$ Weather sation KP60

$\triangle \quad$ Streamgauge

- Absolute pressure gauge (APG)
Figure 38. Map, seismograph, and spectrogram showing evidence for a seiche event on Yellowstone Lake in 2012. $A$, Bathymetric map (Morgan and others, 2007) of Yellowstone Lake showing locations of Yellowstone Caldera (black dotted line), both resurgent domes (black long-dashed lines), and instrument locations for this study. The solid green line (in the inset) indicates the Yellowstone National Park boundary. $B$, Seiche signals recorded between July 11 and July 13, 2012, on APG (top), B944 areal strain (middle), and B206 areal strain (bottom). All time series band pass filtered between 8 hours and 20 minutes. C, Spectrogram of APG (top), B944 areal strain (middle), and B206 areal strain (bottom). Frequency is in cycles per hour (left axis), with a 78-minute period indicated at the right. The colors in the spectrum range represent high spectral energy (red) to low spectral energy (blue) at the time/frequency shown. See Luttrell and others (2013) for a detailed discussion. Abbreviations: cm, centimeters; ns, nanoseconds. 


\section{Stop 8. West Thumb Overlook Trail}

Hike to the top of West Thumb Overlook trail $(0.75 \mathrm{mi}$ round trip). Hiking west on the trail, we cross Quaternary sediments and exposures of white sinter associated with mildly active hydrothermal springs. Capping the upper hill are exposures of the tuff of Bluff Point. Acid-sulfate hot springs are present along the eastern edges of the lava flow.

Immediately to the north and west are exposures of the Dry Creek flow, one of the oldest documented rhyolite lava flows of the Central Plateau Member dated to $0.166 \pm 0.009 \mathrm{Ma}$ (Christiansen and others, 2007). Locally, exposures of the tuff of Bluff Point are stratigraphically above and closely associated with the Dry Creek flow.

From here, we have an excellent panoramic view of (1) the southern margin of the 2.08-Ma first-cycle caldera, (2) the southern and eastern topographic margins of the $0.63-\mathrm{Ma}$ Yellowstone Caldera, (3) the West Thumb Basin, and (4) Yellowstone Lake and postcaldera lavas. We are standing on the tuff of Bluff Point, a welded to densely welded, pumice-, glass-, and crystal-rich ignimbrite.

Return to vehicles. If time allows, we will drive north a short distance and turn right (east) for West Thumb Geyser Basin (Stop 9). 0.3

47.2 Turn onto U.S. Route 14 toward Yellowstone Lake and West Thumb Geyser Basin. 0.2

47.5 Turn into the West Thumb Geyser Basin parking lot.

\section{Stop 9. West Thumb Geyser Basin}

West Thumb Geyser Basin represents a relatively small but impressive and varied thermal area on the southwest shore of West Thumb Basin; one of the most scenic areas in the park. West Thumb Basin formed as a smaller caldera in response to the eruption of the tuff of Bluff Point within the much larger 75-km- by 45-km-wide Yellowstone Caldera when the tuff of Bluff Point was erupted about 0.170 Ma (Christiansen, 2001). The West Thumb Caldera (figs. 21, 22, 36), while relatively small by Yellowstone standards, is about $6 \mathrm{~km}$ by $8 \mathrm{~km}$ wide, similar in size to the very impressive Crater Lake Caldera of Mount Mazama, Oregon.

The West Thumb Geyser Basin has active but infrequent geyser eruptions. More common are the deep thermal pools (at or near the boiling point of water) and extensive siliceous sinter terrace deposits that form due to overflow of the thermal pools. The small pools are steep-sided and conical-shaped pools, and probably form by dissolution. Occasional blocks of sinter ejecta can be seen in the southeastern part of the thermal basin, indication of a historical explosion from an obscure source in that area. Infrequent and intermittent geysers at West Thumb Geyser Basin include Occasional Geyser, Twin Geysers, and Lakeshore Geyser. Twin Geysers and Abyss Pool produce occasional violent eruptions. Twin Geysers erupted in 1934, sending mud, sticks, and boiling water about $120 \mathrm{ft}(65 \mathrm{~m})$ high. Abyss Pool erupts occasionally to heights of $100 \mathrm{ft}(30 \mathrm{~m})$, sometimes throwing out chunks of siliceous sinter and disrupting bacterial mats in and around the deep pool.

West Thumb Geyser Basin also hosts Collapse Pool, which shows evidence of collapse of the sinter rim into the pool as a result of the 1959 Hebgen Lake earthquake. West Thumb Paint Pots represents a lone acid-sulfate steam area with a variety of pastel-colored muds that are now flooded by groundwater and have a soapy, frothy appearance. Thermophilic cyanobacteria are common at West Thumb along drainage channels on the sinter terrace and around the periphery of hot springs and mud pots, resulting in a variety of red, orange, pink, and green colors.

Hydrothermal fluids at West Thumb Geyser Basin are typical alkaline-chloride fluids (figs. 13 and 14) with a $\mathrm{pH}$ range of 7.3 to 8.2. Fluids are $\mathrm{Na}$ and $\mathrm{Cl}$ rich, with lesser $\mathrm{K}, \mathrm{SO}_{4}$, and variable $\mathrm{HCO}_{3}$ concentration (table 3 ). $\mathrm{SiO}_{2}$ ranges from 232 to 360 milligrams per liter $(\mathrm{mg} / \mathrm{L})$, typical of sinter-depositing alkaline-chloride fluids in Yellowstone National Park.

Along the shore, and offshore for as much as $100 \mathrm{~m}$, are submerged hydrothermal vents (Morgan and others, 2007a, b). Three of these vents have sinter cones that rise above lake level except during periods of high water. One of these is Fishing Cone, where the Hayden party first suggested the now famous "hook and cook" technique, where members of the Hayden party caught fish with their hooks and then submerged the fish in the hot water thereby cooking the fish. Farther offshore, in 3 to $4 \mathrm{~m}$ of water, low temperature $\left(15-20^{\circ} \mathrm{C}\right)$ vents commonly are grazed by schools of cutthroat trout. Offshore sinter deposits near West Thumb Geyser Basin are characterized by $\delta^{18} \mathrm{O}$ values (20.6 to 21.4 per mil) indicative that they formed subaerially when the lake level was lower (Shanks and others, 2005, 2007).

Other nearshore hydrothermal vents in shallow water off West Thumb Geyser Basin are frequented by native cutthroat trout that feed on amphipods and bacteria. Vent fluids are enriched in $\mathrm{As}, \mathrm{Sb}, \mathrm{Hg}, \mathrm{Tl}, \mathrm{Mo}$, and $\mathrm{W}$, which has raised concern about potentially toxic metals in edible fish and in the lake trout that feed on native and threatened cutthroat trout. Investigations have indicated significant mercury $(\mathrm{Hg})$ in both cutthroat and lake trout muscle and liver tissue, averaging 0.2 milligrams per kilogram $(\mathrm{mg} / \mathrm{kg})$ wet weight, with some samples exceeding the World Health Association limit of $0.5 \mathrm{ppm}(0.2 \mathrm{mg} / \mathrm{kg})$ (Chaffee and others, 2007).

Return to vehicles and retrace the path over Craig Pass back to Old Faithful. 17.7

65.2 Arrive at Old Faithful at 5 p.m. You now have free time and dinner on your own. We will reconvene at 6:30 p.m. for an evening walk around Upper Geyser Basin.

\section{Stop 10. Upper Geyser Basin, Including Old Faithful and Geyser Hill}

The Upper Geyser Basin is underlain by the 0.516-Ma Biscuit Basin rhyolitic lava flow along the Firehole River Basin, 
which is flanked on the east by the bluffs of the 0.164-Ma Mallard Lake flow and on the west by the 0.124-Ma Summit Lake flow (fig. 39). Fluids contributing to the hot springs and geysers of this area transect mainly rhyolitic lava flows en route to the surface, and, due to reaction with rhyolitic glass, carry abundant silica that is deposited as sinter at the surface.

The Upper Geyser Basin contains the largest concentration of active geysers in the world, including Old Faithful, Beehive, Giantess, Lion, Castle, Grand, Grotto, and Riverside Geysers. We will observe an Old Faithful eruption from the boardwalk and then explore Geyser Hill, a large sinter mound to the north across the Firehole River that hosts more than 50 geysers and hot springs.

The waters from Old Faithful and Geyser Hill are all of the alkaline-chloride type (figs. 12-15, 18). Fournier, Christiansen, and others (1994) and Hurwitz and others (2012) have suggested that the fluids rise from a $215^{\circ} \mathrm{C}$ reservoir, based on silica and other geothermometers. Studies of the water isotopes $\left(\delta \mathrm{D}\right.$ and $\left.\delta^{18} \mathrm{O}\right)$ have shown that there is a deep reservoir of hydrothermal fluid underlying the caldera that is mainly meteoric water with a $\delta \mathrm{D}$ of -149 per mil, $\mathrm{Cl}^{-}$concentration of $\sim 315 \mathrm{ppm}$, and temperature of 350 to $400{ }^{\circ} \mathrm{C}$ (Truesdell and others, 1977). The $\delta \mathrm{D}$ of the deep reservoir fluid indicates it is isotopically lighter than present-day surface and groundwater in Yellowstone National Park and is either (1) a mixture of modern waters and waters derived from the last glacial epoch, or (2) waters recharged under colder conditions during the Little Ice Age (Rye and Truesdell, 2007; Yokochi and others 2013). Boiling and conductive cooling of this deep reservoir fluid produces shallower reservoir fluids at temperatures around 200 to $220^{\circ} \mathrm{C}$. The geochemical characteristics of shallower reservoir fluids depend on boiling, mixing with local groundwater, and water-rock reaction (fig. 15).

\section{Old Faithful}

Old Faithful geyser is world renowned because it is a solitary, large, and powerful geyser with regular eruption intervals. It was discovered and named in 1870 by the members of the Washburn Expedition. Eruptions expel 14,000 to 32,000 liters of boiling water to a height of 32 to $56 \mathrm{~m}$ and last from 1.5 to 5 minutes (Vandemeulebrouck and others, 2013). The average height of an eruption is $44 \mathrm{~m}$. Intervals between eruptions can range from 45 to 125 minutes. Eruption timing was 66.5 minutes in 1939, and has slowly increased to an average of about 90 minutes in 2016. Changes in eruption intervals after the $1959 \mathrm{M}_{\mathrm{w}} 7.5$ earthquake at Hebgen Lake were noted at Old Faithful and other geysers in Yellowstone (Marler and White, 1975). Other significant seismic events outside of Yellowstone, nearby and as far away as Denali, Alaska, have had impacts on the geyser and hot spring activity in the vicinity (Husen, Taylor, and others, 2004).

Old Faithful is a global icon and its continuing "geologic health" is of concern to the National Park Service (Old Faithful Science Review Panel, 2014). Old Faithful Geyser (figs. 39, 40) has been studied in much greater detail than most geysers. Exploration of the geyser conduit by video camera and, mostly recently, by acoustic study of hydrothermal tremors in the conduit have produced new insights. The upper part of the main vent conduit and its constriction were defined by Hutchinson and others (1997) by lowering a video camera down the main vent of the geyser. The widening of the main geyser conduit at about $10 \mathrm{~m}$ depth is related to horizontal fractures. Vandemeulebrouck and others (2013) used seismic tremor data collected earlier by Kedar and others (1996) to define a subterranean lateral cavity between Old Faithful and Split Cone Geyser (to the west-southwest) that plays a major role in the eruptive dynamics of Old Faithful Geyser (fig. 40). The acoustic tremor sources are located inside the geyser conduit and in a lateral recharge cavity. Based on these data, the side cavity has a connection to the main geyser conduit of Old Faithful.

\section{Geyser Hill}

Geyser Hill is a $300+-m$-diameter sinter terrace that hosts a large number of hot spring pools and a number of interesting geysers. It demonstrates a remarkable range of occurrence and behavior within a group of vents that emit silica-depositing, alkaline-chloride fluids that tend to be low in $\mathrm{CO}_{2}$ (for example, fig. 18A). Most are at or near boiling conditions $\left(94^{\circ} \mathrm{C}\right.$ at this altitude). Geysers here have the following characteristics: (1) Anemone Geyser erupts as high as $2 \mathrm{~m}$ every 7 to 15 minutes and drains between eruptions; (2) Plume Geyser erupts without warning as high as 7 to $8 \mathrm{~m}$ approximately every hour; (3) Beehive Geyser erupts once or twice a day in a narrow plume as high as 40 to $55 \mathrm{~m}$ and is often preceded by an eruption of a small nearby indicator geyser; (4) Lion Geyser erupts every 1 to 2 days in a series of sequential eruptions as high as $24 \mathrm{~m}$ that are sometimes preceded by "roaring" steam explosions in the conduit; and (5) Giantess Geyser erupts between 2 and 6 times a year and sends a fountain as high as $60 \mathrm{~m}$ accompanied by groundshaking underground steam explosions. Geyser Hill also has many hot springs. On this loop, we will observe large and small pools, boiling and degassing still pools, and pools that form by collapse or explosion. An especially interesting one is Doublet Pool, which produces vibrations, thumps, and surface waves due to bubble collapse (cavitation).

At 9 p.m. return to Old Faithful Lodge. There will be no evening talk.

\section{Day 4: Old Faithful to Mary Bay and Elephant Back Mountain, with Return to Lake Village (Fig. 41)}

0.0 Leave Old Faithful at 7:30 a.m. and head southeast along Grand Loop Road, U.S. Route 191. 17.7

17.7 Turn left at sign to West Thumb Geyser Basin on U.S. Route 14 and follow Grand Loop Road north. 20.6

38.3 Turn right on U.S. Route 14 (U.S. 14) at the north end of Yellowstone Lake. 0.4

38.7 Cross Yellowstone River at Fishing Bridge (fishing no longer allowed); this is the only outlet of Yellowstone Lake. The river here is actually a northward extension 


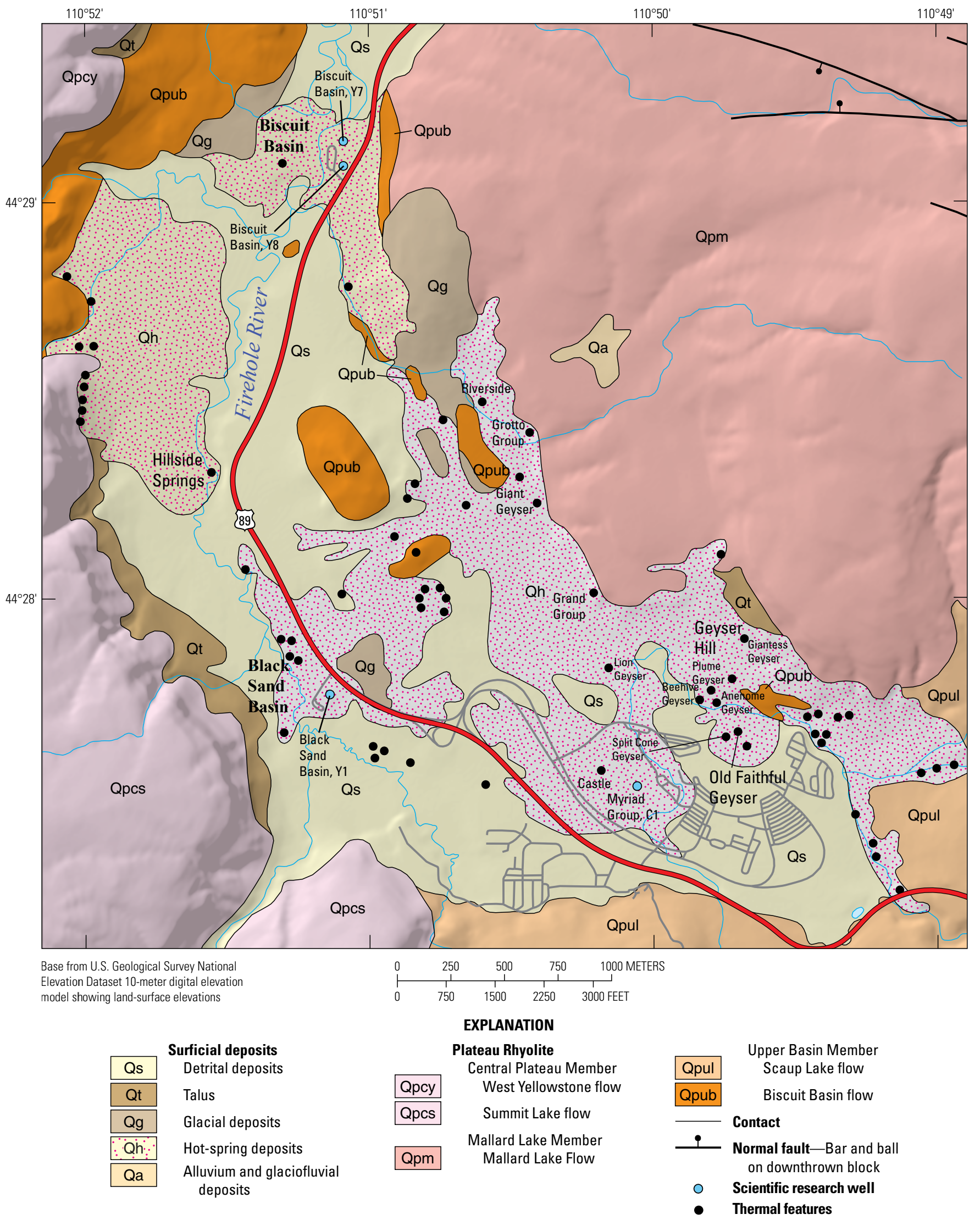

Figure 39. Geologic map of the Upper Geyser Basin area (Stop 10). Wells completed for scientific drilling prior to 1970 are shown as blue dots located at Biscuit Basin (wells Y7 and Y8), Black Sand Basin (well Y1), and the Myriad Group (well C1). Black filled dots represents thermal features. The main road is shown by the heavy red line. Additional roads are shown as gray lines. Geology by Christiansen and Blank (1974). 

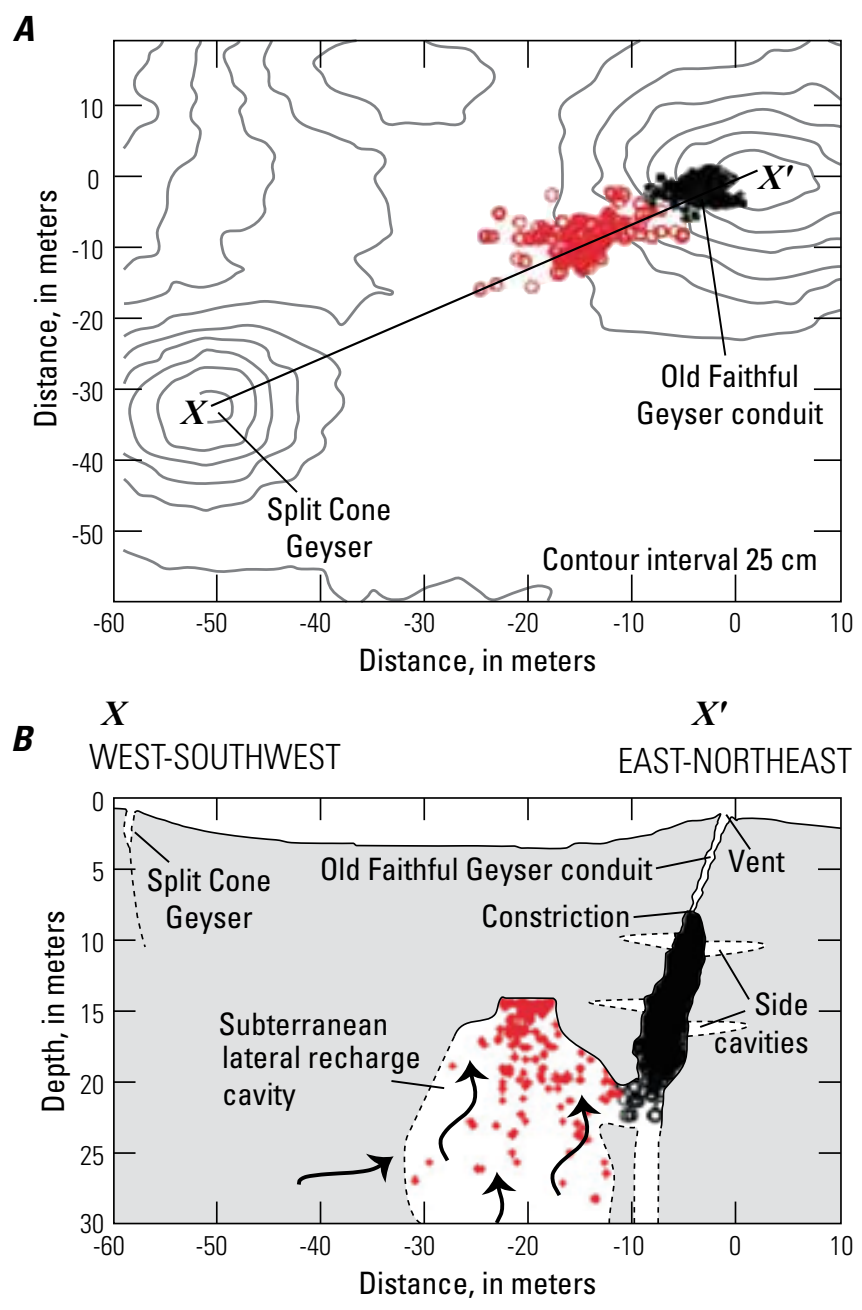

C

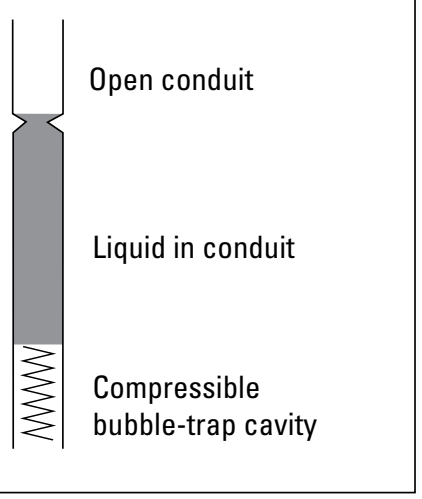

Figure 40. Generalized map and cross section showing hydrothermal acoustic tremor data near Old Faithful Geyser and cross section illustrating the cause of an eruption. $A$, Map of hydrothermal acoustic tremor data showing the sources of tremors (cluster of black dots) in the Old Faithful Geyser conduit and the sources of tremors (red dots) in a significant lateral recharge cavity to the west-southwest. Contours are approximately 25 centimeters. $B$, Cross section $(X-X$, from $A)$ showing how a side cavity adjacent to Old Faithful Geyser traps steam bubbles and creates a compressible phase (illustrated in $C$ ) that is important for harmonic oscillations during the pre-play period before Old Faithful erupts. Arrows represent the flow of fluid into the cavity. The cavity and the conduit are vacated during the eruption. Dashed lines are inferred. $C$, Schematic diagram illustrating how an oscillating liquid-water column over a bubble-trap cavity is compressed and results in a geyser eruption. The compressible bubble-trap cavity is compared here to a massspring harmonic oscillator. Modified from Vandemeulebrouck and others (2013). 


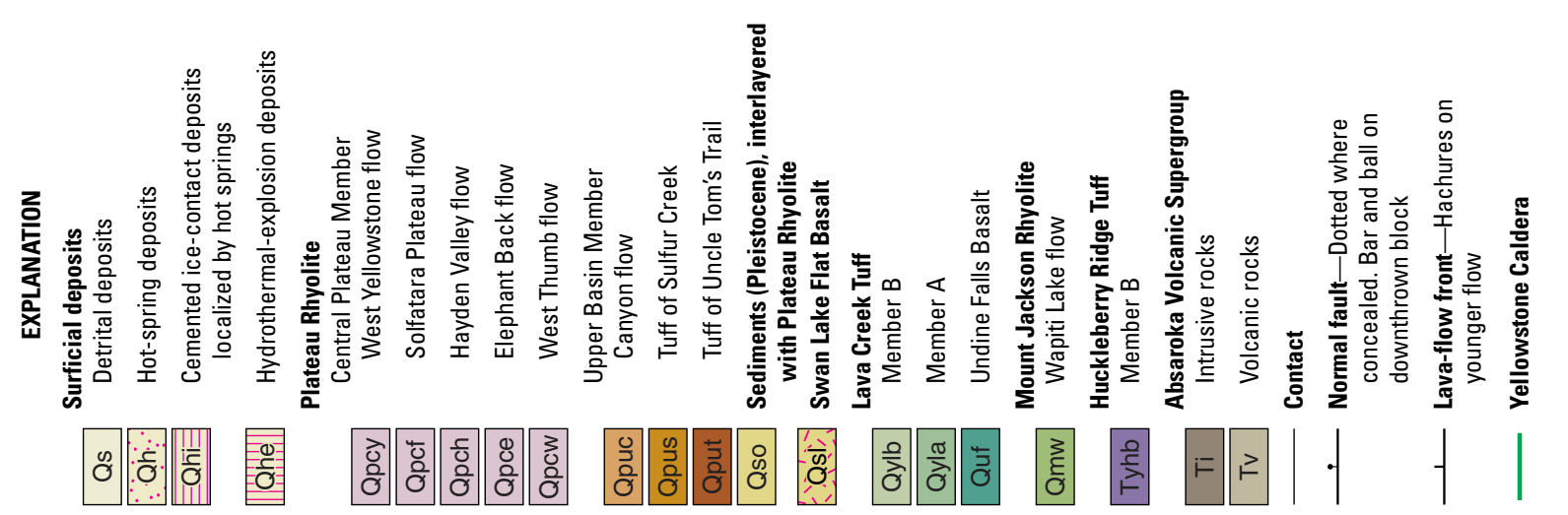

๘

के

เก

高

市

总 車

言 $\frac{\partial}{\mathrm{t}}$

흘 음

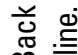

荿

등 궁

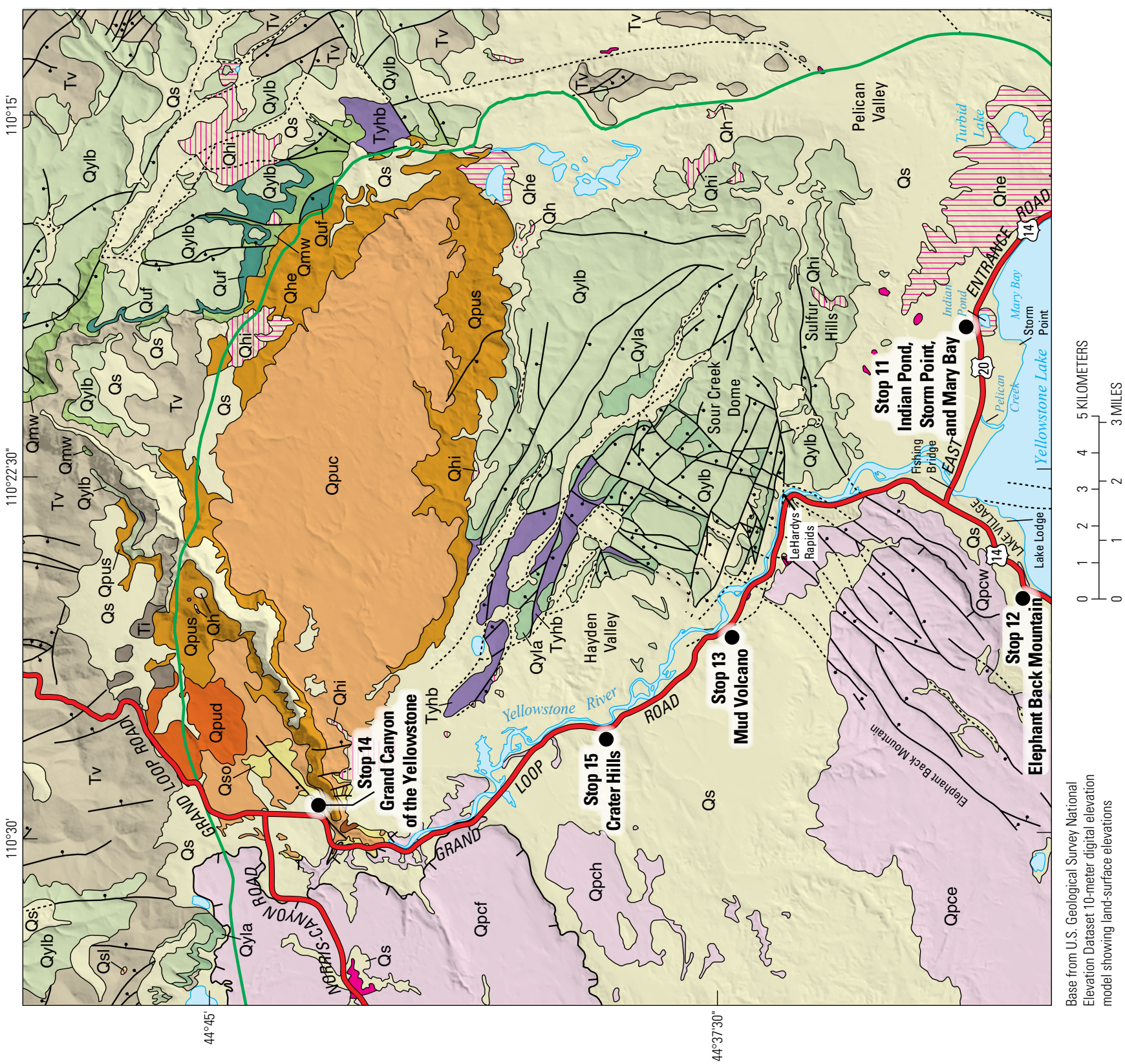

동

츨

을 兘

ते

永

등

吉

혼호

틈 응

के

言

跑

흔

。ํํㅇ

근

总

ส

它

志

क

흥

등

응

옳 空

을 음

흔

들

율 홍

능 음

웡

சं

혼

政 
of the lake itself, which ends at LeHardys Rapids $5 \mathrm{~km}$ to the north.

No gaging stations are on any of the 144 tributaries that feed Yellowstone Lake, though the outlet does have a gaging station just downstream from Fishing Bridge. The dominant inlet is the Yellowstone River, entering Yellowstone Lake at the south end of the Southeast Arm.

Stable isotope studies of lake and stream waters, coupled with estimates of the water budget, indicate the lake waters are 13 percent evaporated. Moreover, $\sim 10$ percent of the total chloride flux from Yellowstone National Park rivers can be tied to sublacustrine vents in the lake (Balistrieri and others, 2007). This calculation, coupled with lake-bottom submersible investigations, indicates that some of the park's largest geothermal fields are in Yellowstone Lake (Shanks and others, 2007). 1.4

40.1 Continue on U.S. Route 14 (East Entrance Road), crossing over Pelican Creek, another tributary to Yellowstone Lake. Farther upstream in Pelican Valley is a common area to see grizzly bears. Once we are east of Pelican Creek, we traverse over the 13-ka Mary Bay hydrothermal explosion breccia deposit (Morgan and others, 2009). To the north side of the road, note a light-colored exposure in the eastern bank of Pelican Creek. This is a distal facies of the Mary Bay hydrothermal explosion breccia exposed in the bluff. As we drive east, the top of the explosion deposit creates a hummocky surface in the sage-covered landscape north of the road. $\mathbf{1 . 7}$
41.8

Arrive at Indian Pond (fig. 42). Turn right and park in one of two small parking lots on south side of road.

\section{Stop 11. Indian Pond, Storm Point, and Mary Bay}

\section{Indian Pond}

We stand on the rim of the Indian Pond hydrothermal explosion crater, a $\sim 500$-m-wide, 2.9-ka crater surrounded by a rim of explosion breccia (Morgan and others, 2009). Indian Pond is one example of at least 20 large $(>100$-m-diameter up to $2.5-\mathrm{km}$-diameter) hydrothermal explosion craters that have been identified within Yellowstone Caldera and along the active Norris-Mammoth Tectonic Corridor (fig. 12; these deposits are known only in the postglacial record $(<16-14 \mathrm{ka})$ in Yellowstone National Park.

Hydrothermal explosions in Yellowstone occur in nearsurface environments where near-boiling water is present. If conditions in this type of environment suddenly change, resulting in a rapid pressure reduction, the contained fluids may flash to steam (fig. $19 C-F$ ), resulting in a significant volume increase, fragmentation of enclosing rocks, and formation of large craters (McKibben, 1990; Smith and McKibben, 2000; Browne and Lawless, 2001). They fall into the category of "non-juvenile eruptions" or "boiling point eruptions" (Mastin, 1995).

The northern part of Yellowstone Lake is well known for its active hydrothermal features, notable explosion craters, and active faulting. For two weeks in late 2008 and early 2009, an earthquake swarm resulted in over 800 located events and a small amount of related crustal deformation (Farrell and others, 2010). Maximum

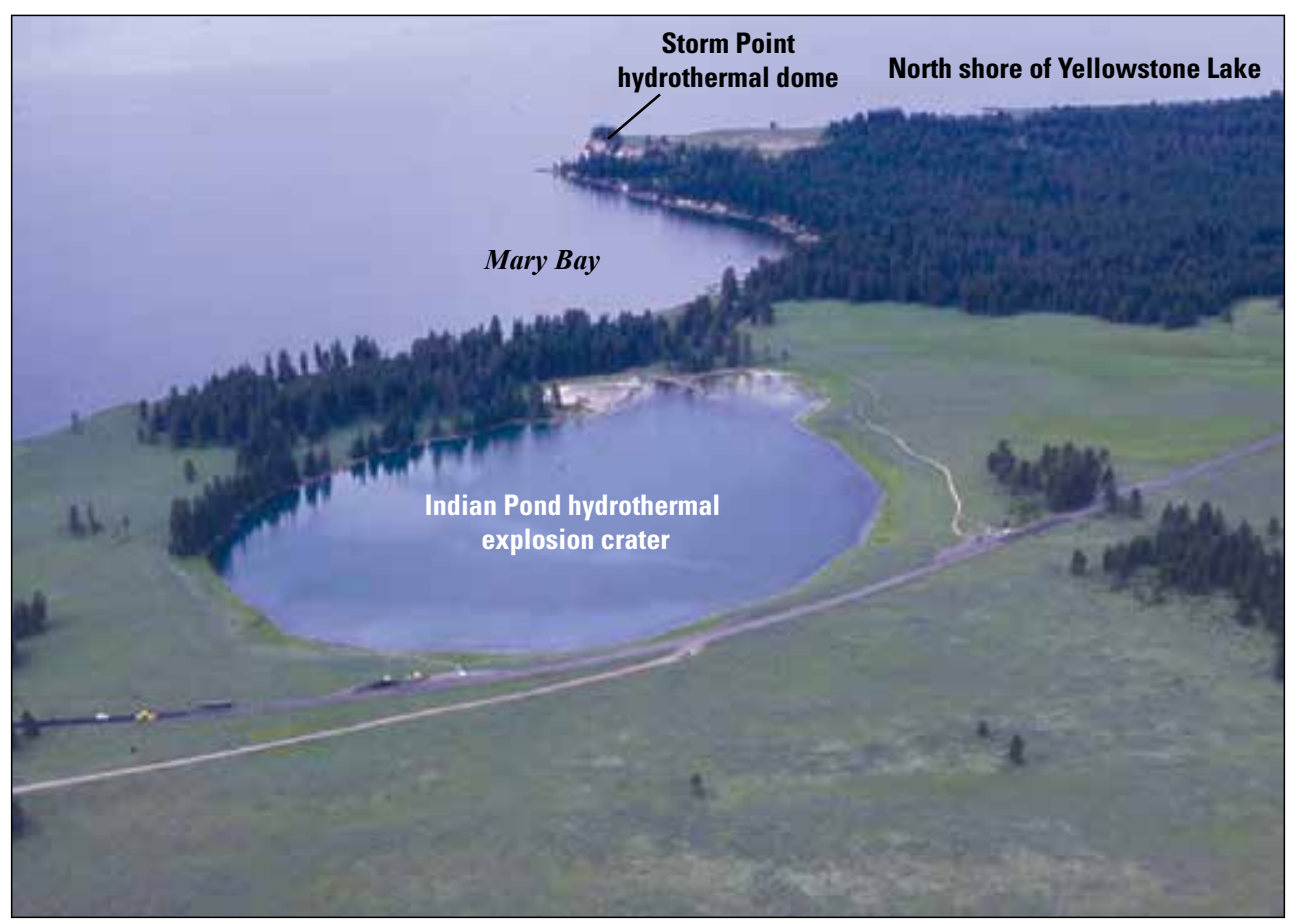

Figure 42. Photograph looking southwest toward Indian Pond, Storm Point, and Mary Bay (Stop 11). Indian Pond is $\sim 500$ meters in diameter. In the background is the Strom Point hydrothermal dome and the north shore of Yellowstone Lake at the western edge of Mary Bay. Photograph by Jim Peaco, National Park Service. 
earthquake hypocenter depths shallowed with time, and the northernmost events migrated north with time (fig. 43). Farrell and others (2010) interpreted the activity as related to a migration of deep magmatic or hydrothermal fluid.

To the north of Indian Pond is the Sour Creek Dome, one of two postcaldera resurgent domes in the Yellowstone Caldera. Note the rectilinear faults of the dome, which have displaced intracaldera facies of the Lava Creek Tuff. Sulphur Hills thermal basin caps the resurgent dome on the south. Extensive acid-sulfate hydrothermal alteration here is associated with abundant and active hydrothermal springs, fumaroles, related sulfur precipitates, and kaolinite deposits. The two hydrothermal explosion craters at Sulphur Hills are considered to be recently formed (Morgan and others, 2009). Hydrothermally cemented ice-contact deposits are exposed above variably altered Lava Creek Tuff. Also, Sulphur Hills is one of Yellowstone's most intense thermal anomalies as imaged with satellite thermal infrared data (Vaughan and others, 2012, 2014).

Southeast of Sulphur Hills is Turbid Lake, a 10.3-ka hydrothermal explosion crater complex, the second largest documented explosion crater in the world. To the east, the Absaroka Range (fig. 1), composed of 54- to 47-Ma Tertiary volcanic rocks, marks the eastern topographic margin of the third-cycle caldera.

Begin a 2.6-mile $(\sim 4.2 \mathrm{~km})$ hike to Storm Point and along the north shore of Yellowstone Lake. Walk along the west side of Indian Pond to the northern shore of Yellowstone Lake (fig. 42) where, from east to west, we can look into the Mary Bay embayment and view notable features such as the white slopes of the north crater wall of the Mary Bay hydrothermal explosion crater, Holmes Point (the eastern edge of the Mary Bay explosion crater), and Steamboat Point (actively steaming) (fig. 21). Farther southeast is Lake Butte (fig. 21), an intermediate composition intrusive rock associated with Eocene Absaroka volcanism; the topographic margin of Yellowstone Caldera emerges from Yellowstone Lake on the northwest side of the butte. To the south in the distance, the northern edges of Mount Sheridan and Flat Mountain (fig. 1) mark the southern topographic margin of the Yellowstone Caldera. To the west, along the northern shore of Yellowstone Lake, Storm Point (fig. 21), a 6- to 4-ka hydrothermal dome, is elevated above the surrounding terrain (Pierce and others, 2007). Sedimentary strata exposed on the dome dip away in all directions from the central high area.

\section{Storm Point}

Located along the northern shore of Yellowstone Lake, the Storm Point area stands about 10 to $20 \mathrm{~m}$ above lake level. Storm Point is a structural dome related to a large center of hydrothermal activity. Doming is evident in high resolution lidar data (Pierce, Cannon, and others, 2002) and in the diversion of stream channels away from these uplifted areas. The structure measures $\sim 840 \mathrm{~m}$ long by $795 \mathrm{~m}$ wide and has multiple craters exposed on its top (Morgan and others, 2009). Dips measured on bedded, cemented beach sands and gravels and altered laminated lake sediments on the eastern, southern, and western edges of the dome range from $8^{\circ}$ to $15^{\circ} \mathrm{E}$., $15^{\circ}$ to $22^{\circ} \mathrm{S}$., and $5^{\circ}$ to $8^{\circ} \mathrm{W}$., respectively. West of Storm Point, the 8-ka S2 shoreline and younger shorelines are tilted away from Storm Point $\sim 6 \mathrm{~m}$ over a distance of $1 \mathrm{~km}$ (Pierce and others, 2007).

At the edge of Yellowstone Lake, proceed west and south along the trail through spruce forest to the clearing at Storm Point. At least 30 hydrothermal craters occupy the top of the Storm Point Dome; individual craters range in diameter from $\sim 5 \mathrm{~m}$ to as large as $80 \mathrm{~m}$. Many are compound craters with smaller craters nested in a larger parent crater. Hydrothermal explosion breccia is associated with some of the craters. Most craters here do not have a rim of ejecta around their edges. This may be explained if the ejected material were predominantly sinter, because this would disintegrate rapidly. Marler and White (1975) described large sinter blocks ejected from Link Geyser in Upper Geyser Basin that disintegrated within a decade. At Storm Point, however, the substrata are mostly resistant silicified gravel and lake sediment and, thus, an alternative explanation for the lack of an ejecta rim associated with craters here is that most craters may have formed by collapse and (or) dissolution; this would be consistent with the absence of ejected blocks. Some craters are rimmed by isolated tilted blocks of hydrothermally cemented beach sands and sediments and contain no breccia fragments. Fine, well-sorted eolian sands cover the floors of the craters.

Follow the trail to west along the north shore of Yellowstone Lake and look at the hydrothermal alteration and deformation features present in sediments exposed on the south side of the dome. Thermal activity continues at present. Active hydrothermal vents are in the lake at the southern edge of the Storm Point. Temperatures as high as $68^{\circ} \mathrm{C}$ have been measured with shallow probes in the fine, sand-filled craters; typical temperatures range between $18{ }^{\circ} \mathrm{C}$ and $56^{\circ} \mathrm{C}$.

Return to the trail and climb to top of Storm Point, where one has an excellent view into the Mary Bay embayment and overview of Yellowstone Lake.

Return to the trail we came in on. Continue walking east and cross Little Indian Creek drainage. Turn right and walk to the northern shore of Yellowstone Lake on east side of Storm Point. Head east on the north shore of Yellowstone Lake and pass lake sediments exposed on terraces. High winds and the fetch across the lake of approximately $35 \mathrm{~km}$ contributes to erosion and formation of the high, wave-cut terraces exposed along the northern shore. Significant shoreline erosion here results in exposures that are constantly changing.

\section{Mary Bay}

Continuing east, hydrothermal explosion deposits from three explosion events are exposed (fig. 44). These include explosion breccia from the Mary Bay event at $13.0 \mathrm{ka}$, the Turbid Lake event at $9.4 \mathrm{ka}$, and the Indian Pond event at $2.9 \mathrm{ka}$ (Morgan and others, 2009). The most continuous and best exposed unit here is the Mary Bay deposit derived from a sublacustrine hydrothermal explosion crater complex. At 


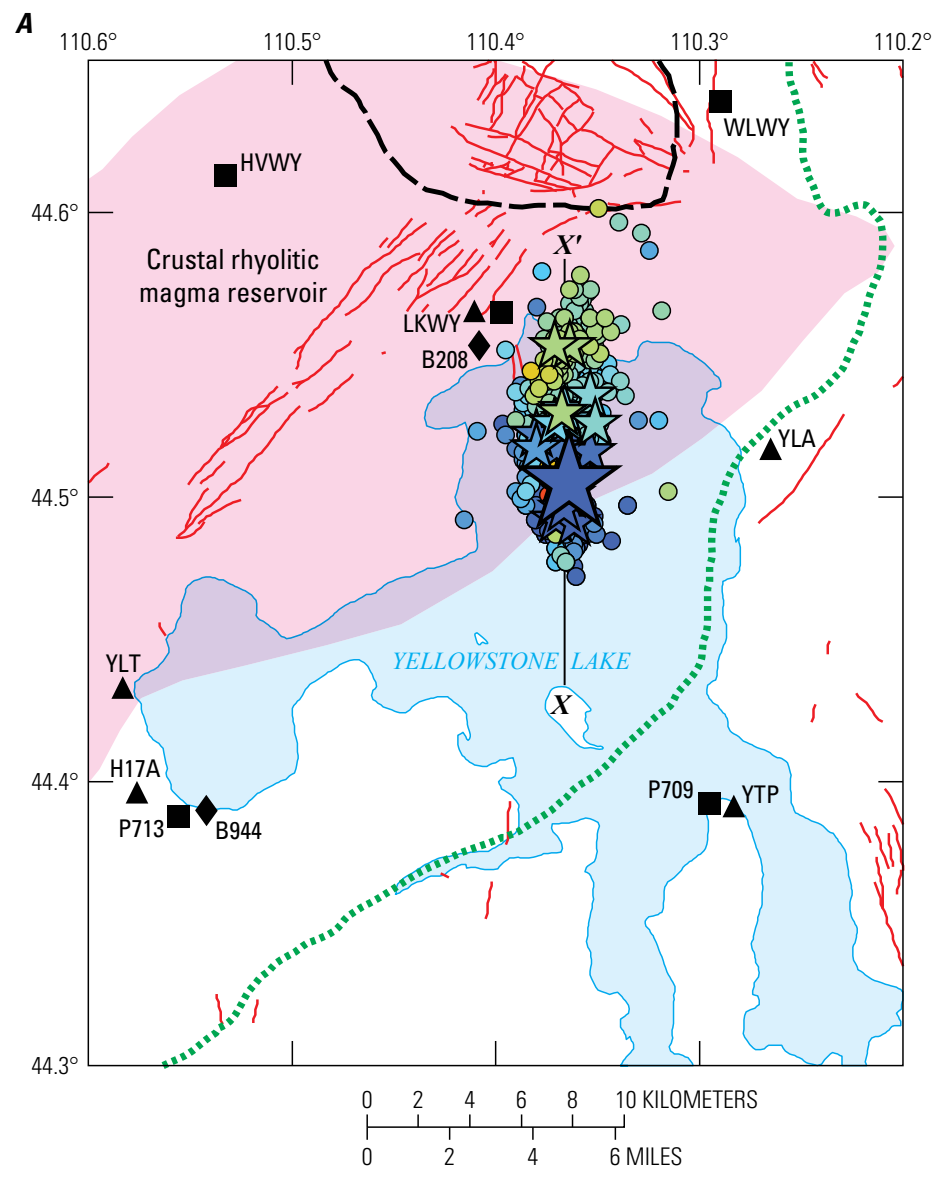

B
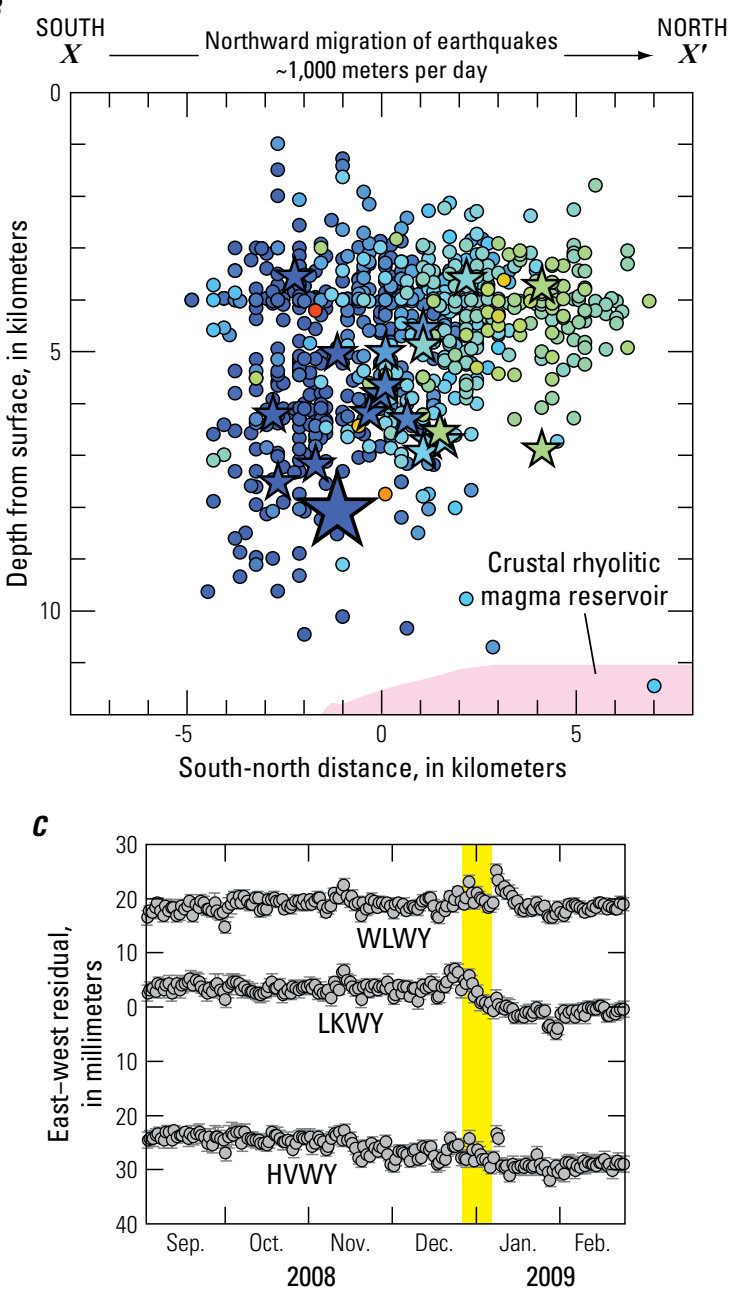

\section{EXPLANATION}

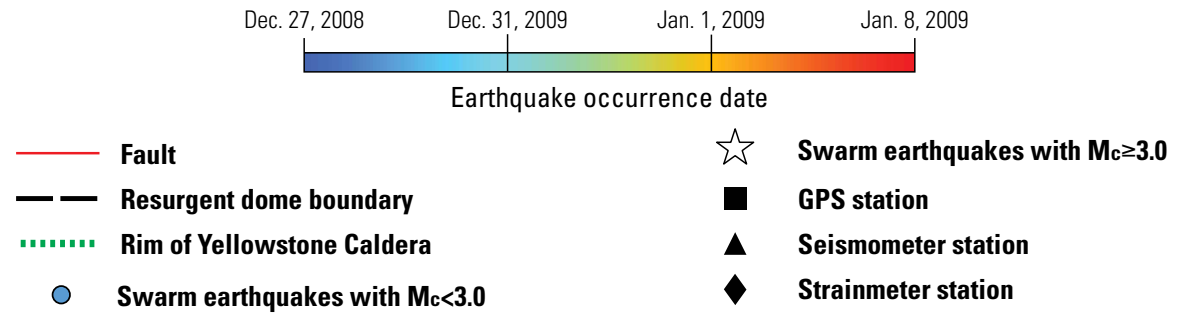

Figure 43. Yellowstone Lake earthquake swarm from 2008 to 2009 (from Farrell and others, 2010). A, Map of epicenters color coded by date showing the northern migration of the seismicity. Circles represent swarm earthquakes with $\mathrm{M}_{\mathrm{C}}<3.0$ and stars represent events with $M_{c} \geq 3.0$. The largest star is the largest recorded earthquake $\left(M_{w} 4.1\right)$. The pink area represents the lowseismic-velocity body interpreted as a shallow crustal rhyolitic magma reservoir (Husen and others, 2004). The lettered and numbered symbols represent seismic and GPS stations. $B$, Cross section of hypocenters along $X-X$ in $A$. Earthquakes moved northward and shallowed with time. Symbols are the same as in $A$. $C$, East-west component of GPS-derived ground motion of the Yellowstone Lake area stations WLWY, LKWY, and HVWY showing the related deformation. Grey circles represent the daily solutions of the position of each GPS station. A small deformation transient on station LKWY (within 1 kilometer of the swarm) accompanied the swarm of earthquakes in late December 2008, to early January 2009 (shown as the yellow band). Abbreviations: GPS, global positioning system; $\mathrm{M}_{\mathrm{C}^{\prime}}$ coda magnitude; $\mathrm{M}_{\mathrm{w}^{\prime}}$ moment magnitude. 


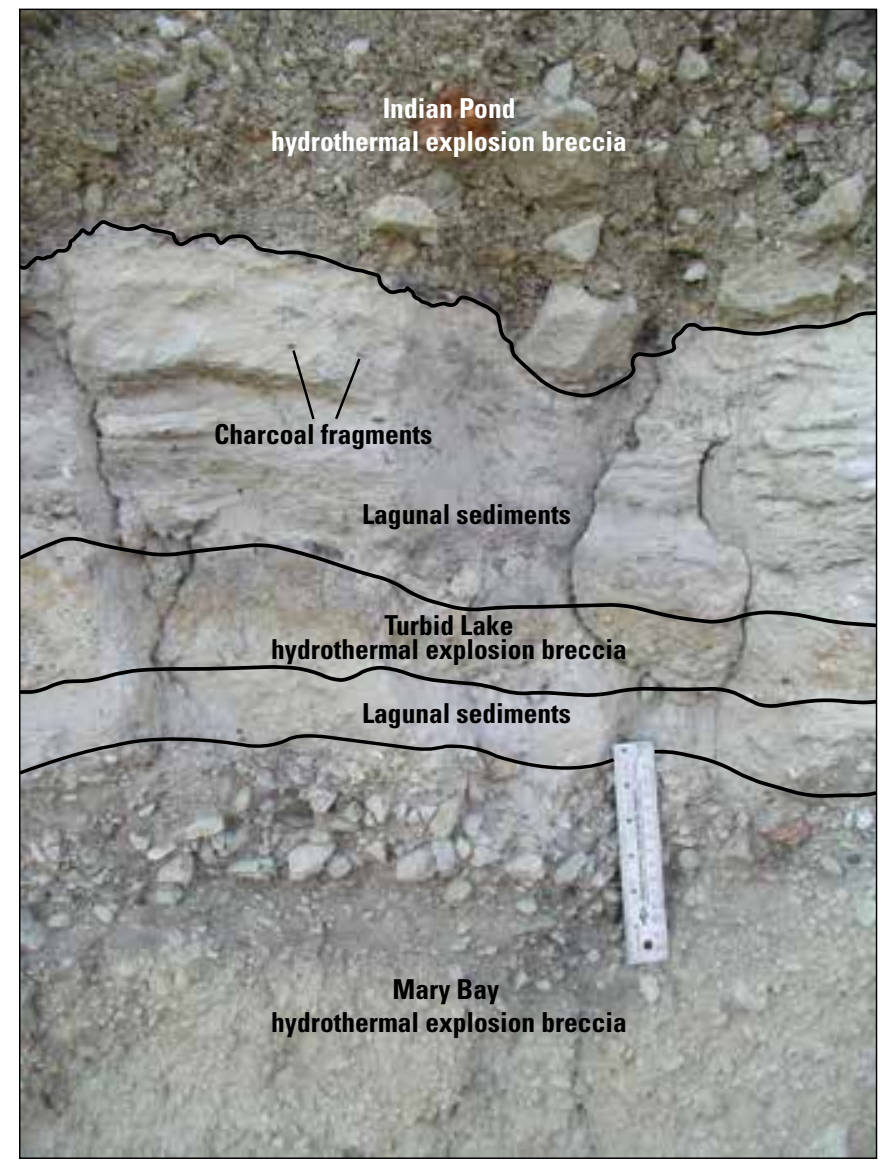

Figure 44. Photograph of hydrothermal explosion deposits along the north shore of Yellowstone Lake (Stop 11). The photograph shows the explosion breccia stratigraphy in wave-cut terraces west of Mary Bay including the Indian Pond, Turbid Lake, and Mary Bay hydrothermal explosion breccias intercalated with lagunal sediments. Following the Mary Bay explosion event, deposition of lagunal and lacustrine (lake) sediments continued until $9.4 \mathrm{ka}$, when a distal facies of the Turbid Lake explosion breccia was deposited along the shores of northern Yellowstone Lake about 4.5 to 5 kilometers from the center of the Turbid Lake crater. This deposit is separated from the overlying Indian Pond explosion breccia by 25 centimeters $(\mathrm{cm})$ of lagunal sediments. Above this is a soil containing charcoal fragments that yielded an age of $\sim 3.1 \mathrm{ka}$, which is immediately overlain by $40 \mathrm{~cm}$ of greenish-stained Indian Pond explosion breccia. The sequence is capped by 1.5 to 2 meters of eolian sand (not shown on figure). The Indian Pond explosion breccia is the last major hydrothermal explosion deposit known in this area.

$2.6 \mathrm{~km}$ in diameter, this is the world's largest documented hydrothermal explosion crater. In the subaerial environment north of Yellowstone Lake, the Mary Bay explosion deposit is distributed from its crater rim $\sim 3.5$ to $4 \mathrm{~km}$ to the northwest and 2.5 to $3 \mathrm{~km}$ to the northeast and covers $\sim 30 \mathrm{~km}^{2}$. Fragments in the Mary Bay breccia are as large as $2.8 \mathrm{~m}$ in maximum dimension and include hydrothermally altered rhyolitic lava flow, cemented beach sand and gravels, multigenerational silicified breccias, silicic veins and silicified lake beds, and a variety of older rocks derived from the subsurface. These reveal a long history of pre-explosion alteration, vein development, mineralization, and brecciation. The discovery of lead-, tin-, and copper-bearing minerals in some lithic clasts suggests that the explosion derived from the deep-seated portions of the hydrothermal system.

We also will examine the Black Dog breccia pipe, which represents an extinct, exposed sublacustrine vent. It consists, from bottom to top, of several small veins that crosscut laminated lake beds, a zone of open channelways for hydrothermal fluids, a 1-m-diameter breccia pipe, a zone of silicified lake beds, and a cap of silicified Mary Bay breccia. Between January and June 2012, headward erosion on the north shore of Yellowstone Lake finally surrounded the silicified breccia pipe and by June 2012, the welldocumented breccia pipe on the northern shore of Yellowstone Lake had fallen on its side.

Return to cars and head west, back to Fishing Bridge. 3.5

45.3 A restroom stop is located slightly east of Fishing Bridge Visitor Center, located on south side of the road across from the gas station. The Visitor Center has a three-dimensional, solid-terrain model of Yellowstone Lake based on high-resolution bathymetric mapping (Morgan and others, 2007a).

Drive west on U.S. Route 20, cross Fishing Bridge, and head south on Grand Loop Road to the Elephant Back Mountain Trailhead (drive 1.1 miles $[\sim 1.8 \mathrm{~km}]$ from the intersection to the parking lot on west side of the road). $\mathbf{4 . 6}$

49.9 Arrive at the Elephant Back Mountain parking area. We will hike $\sim 3.6 \mathrm{mi}(5.8 \mathrm{~km})$ round trip with a $720-\mathrm{ft}$ (220-m) elevation gain up Elephant Back Mountain to Stop 12.

\section{Stop 12. Elephant Back Mountain}

Elephant Back Mountain (figs. 21, 41, 45) is a prominent feature with active northeast-trending fractures that accommodate strain between the two resurgent domes, the Sour Creek Dome directly to the northeast and the Mallard Lake Dome (fig. 1) directly to the west and northwest. The resurgent domes have a complex geologic history ranging from early postcaldera volcanism (0.45-0.60 Ma) to most recent postcaldera rhyolitic volcanism ( $\sim 170-0.070 \mathrm{Ma})$. Emplacement of the $0.164 \pm$ 0.014-Ma Mallard Lake flow at the Mallard Lake Dome is close in time with volcanism represented at Elephant Back Mountain.

As we hike to the top of Elephant Back Mountain, we will observe two postcaldera rhyolitic lava flows; the lower $0.173 \pm 0.011$-Ma West Thumb flow is capped by exposures of the $0.153 \pm 0.002-$ Ma Elephant Back rhyolite flow (Obradovich, 1992).

Notable northeast-trending fractures form elongate valleys and represent active deformation associated with the Yellowstone Caldera (Dzurisin and others, 2012). As described 


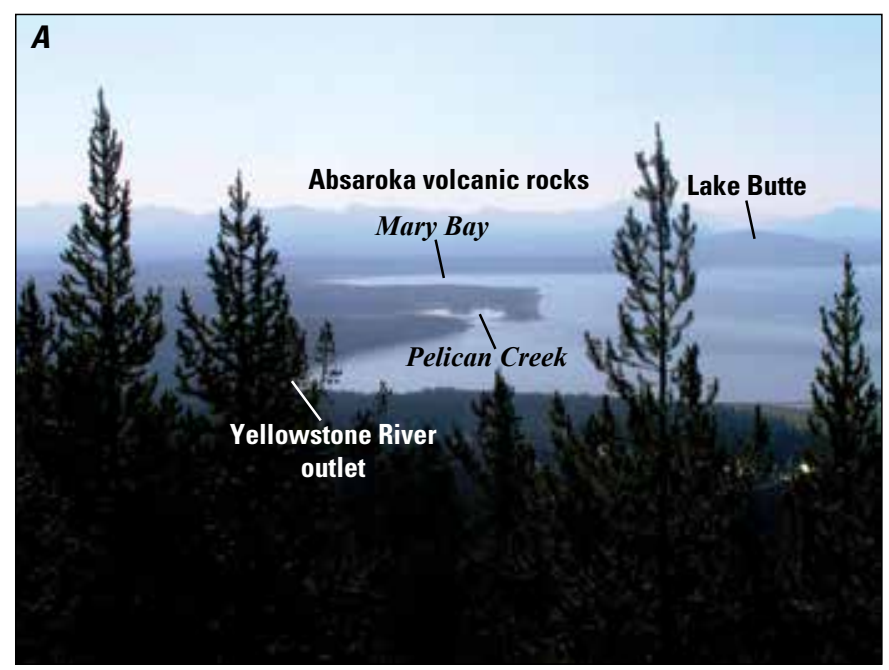

\section{Day 5: Lake Village to Mud Volcano, Grand Canyon of the Yellowstone, Crater Hills, and Return to Lake Village (Fig. 41)}

Leave Lake Lodge at 7:30 p.m. At the intersection with Grand Loop Road, turn right and head north to Mud Volcano (fig. 41). 0.8

Turn right on Grand Loop Road. 0.8

1.6 Continue north past the intersection with the East Entrance Road, and follow the Yellowstone River north as it cuts its way downstream between the contact of the Sour Creek Dome to the east and the postcaldera lavas of Elephant Back Mountain to the west. As we proceed north, note to your right (east) the stream gradient of the Yellowstone River, which is a drowned valley, or a northward extension of

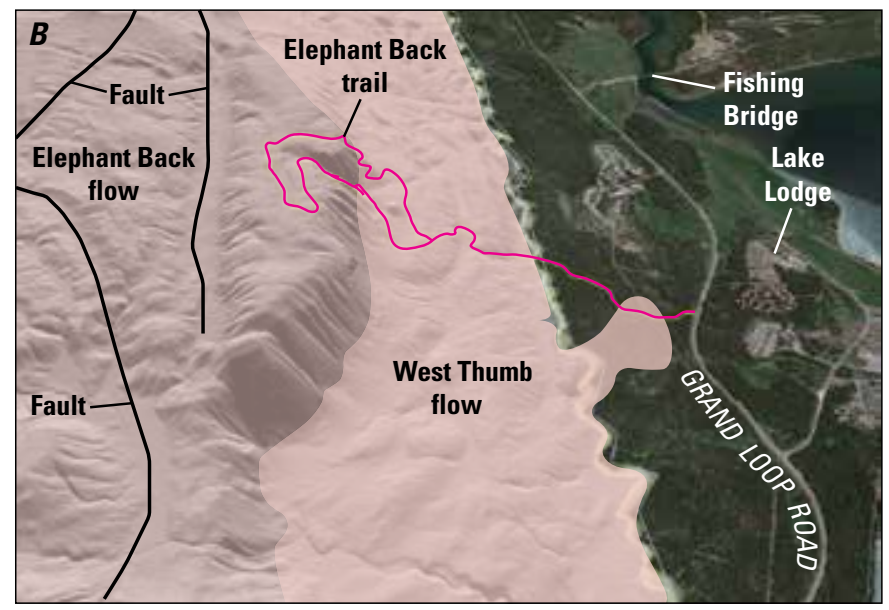

Yellowstone Lake. On your left (west), note the excellent exposures of the West Thumb flow at the base of Elephant Back Mountain, which we hiked by yesterday. Here are exposures of the distal facies of a compound lava flow where several individual flows are exposed one above the other. 3.7

5.3 Here at LeHardys Rapids a rapid change in stream gradient occurs. Located between the Sour Creek Dome and Elephant Back Mountain, LeHardy Rapids acts as a northeast-trending axis of uplift and subsidence associated with the active deformation of the Yellowstone Caldera (an extension of the Elephant Back faults). The rapids flow over a densely welded section of intracaldera Lava Creek Tuff, which serves as a threshold that controls the level of the Yellowstone River and Yellowstone Lake. Doming along the northeast-trending caldera axis reduces the gradient of the Yellowstone River from LeHardy Rapids (south) to the Yellowstone Lake outlet at Fishing Bridge and ultimately causes an increase in lake level (Morgan and others, 2008). Uplift and subsidence cycles of the central part of the Yellowstone Caldera may reflect a combination of several processes in addition to postglacial isostatic rebound including: (1) magmatic inflation, (2) tectonic stretching and deflation, and (3) inflation from hydrothermal fluid sealing, followed by cracking of the seal, pressure release, and deflation (Pierce and others, 2007). Paleoshorelines descend toward the caldera axis, indicating that although inflation has periodically occurred, no net buildup of the center of the caldera has occurred (Pierce, Cannon, and others, 2002). 2.9

active deformation of the Yellowstone Caldera, and history of leveling and geodesy at Yellowstone.

Hike back to the trail head and return south to Lake Village. $\mathbf{0 . 5}$

55.2 From Grand Loop Road, turn left at Lake Village (fig. 41) at mile 55.2 and proceed to Lake Lodge (figs. 41, 45). There will be an evening lecture at 7 p.m.

Arrive at Mud Volcano. Park in the lot (west of the road). Mud Volcano is a great example of migrating hydrothermal systems that reflect seasonal changes and is the site of a large hydrothermal explosion in 1948. 


\section{Stop 13. Mud Volcano (Fig. 41)}

Hike up and around along the boardwalk areas $(\sim 1.0 \mathrm{mi}$ [1.6 km]) and examine and discuss (1) gas discharge, (2) the 1948 hydrothermal explosion crater, (3) the migration of the hydrothermal field since 1978, (4) hydrothermal alteration processes, (5) the Sour Creek resurgent dome, and (6) deformation of the Yellowstone Caldera.

The Mud Volcano thermal area is one of the more easily accessible acid-sulfate areas within the park. Acid-sulfate waters are created by the dissolution and oxidation of $\mathrm{H}_{2} \mathrm{~S}$ within shallow meteoric-derived perched groundwater (figs. 13, 14; table 3). Much of the conversion of $\mathrm{H}_{2} \mathrm{~S}$ to sulfuric acid is biologically mediated (Nordstrom and others, 2009). The acid reacts with surface rocks and sediments to form a clay-altered terrain dominated by kaolinite and alunite (Livo and others, 2007). Alkaline-chloride waters, which are so common to the west along the Firehole River (fig. 39), are rare at Mud Volcano, and spring discharge is notably minor compared with the geyser basins (Allen and Day, 1935), totaling only 80 liters per minute for the entire $2.5-\mathrm{km}^{2}$ area of Mud Volcano.

The acid chemistry at Mud Volcano is due to a vapordominated reservoir of steam that overlies a slightly alkaline geothermal reservoir (White and others, 1975). Anomalous gas and steam discharge also occur across the Yellowstone River. Careful inspection of the river near Mud Volcano reveals vigorous gas venting through the river bottom without any obvious associated heat.

Most of the Mud Volcano area is covered with Pinedale glacial deposits, though exposures of intracaldera Lava Creek Tuff are found in an outcrop at Dragons Mouth Spring and near Sulfur Cauldron. In 1968, the U.S. Geological Survey drilled into the area to a depth of $105.7 \mathrm{~m}$ (the $\mathrm{Y}-11$ research drill hole). After penetrating the upper $15 \mathrm{~m}$ of fluvial and glacial deposits that caps a short section of postcaldera tuff beds, the well penetrated another $86.2 \mathrm{~m}$ of Lava Creek Tuff (Bargar and Muffler, 1982). Hydrothermal alteration was formed by an early neutral hot-water system, followed by the later (and still-present) vapor-dominated system. Minerals related to the current acid alteration include opal, kaolinite, alunite, pyrite and montmorillonite (Bargar and Muffler, 1982). The Y-11 research drill hole was considered to be at the edge of a vapor-dominated system, with sufficient liquid water in fractures and pores to ensure a pressure gradient intermediate between vapor-static and hydrostatic (White and others, 1975).

The fumaroles and frying pans (sizzling ground) at Mud Volcano are higher in gas than any other location in the park, ranging from 10 to 15 percent $\mathrm{CO}_{2}$ primarily, with the remainder present as steam (Bergfeld and others, 2011). They yield the highest helium isotope ratios $\left({ }^{3} \mathrm{He} /{ }^{4} \mathrm{He}\right)$ found at Yellowstone and some of the highest for thermal waters in the world at $\sim 16$ R/Ra (Craig and others, 1978; Kennedy and others, 1985). This reflects a clear mantle signature, often interpreted as due to a mantle plume (Craig and others, 1978). Moreover, crustal gases such as $\mathrm{CH}_{4}$ and radiogenic ${ }^{4} \mathrm{He}$ are very low, presumably because the connection to magma is more direct at this location than any other at Yellowstone (Lowenstern and others, 2015).
Other areas around the Sour Creek Dome show considerably more evidence for crustal contributions to the emitted gas (fig. 16). There is a clear anti-correlation at Yellowstone between $\mathrm{He}$ concentration and ${ }^{3} \mathrm{He} /{ }^{4} \mathrm{He}$ (Chiodini and others, 2012), requiring that radiogenic $\mathrm{He}$ is added to thermal fluids by degassing of old metamorphic and sedimentary rocks (Lowenstern and others, 2014).

Werner and others (2000) and Werner and Brantley (2003) observed that diffuse soil degassing was orders of magnitude higher through acid-sulfate soils than through those at alkaline-chloride or travertine-forming thermal areas. Mud Volcano emits about 290 tons per day of $\mathrm{CO}_{2}$ as diffuse emissions, with a similar amount likely dispersed via localized vents (Werner and others, 2000). Similar flux per square kilometer was found at other major acid-sulfate areas at Yellowstone such as Crater Hills, Brimstone Basin, and Hot Springs Basin (Werner and Brantley, 2003; Hurwitz and Lowenstern, 2014).

After walking the boardwalk, gather in the parking lot and together cross to the east side of the road. From here we can look at exposures of intracaldera Lava Creek Tuff.

\subsection{Leave Mud Volcano.}

Continue north along the Grand Loop Road and enter Hayden Valley (fig. 41), a broad glaciated valley within the Yellowstone Caldera. This valley was once occupied by an arm of ancestral Yellowstone Lake (Love and others, 2007) and contains fine-grained, clay-rich lake sediments overlain by glacial till. The soils developed on these glacial lake sediments are rich in nutrients and have an increased water-holding capacity. It presently forms an extensive meadowland supporting a rich, diverse habitat, which includes bison, elk, grizzly bears, and wolves. Note the white, bedded lake sediments exposed in valley slopes. The very glassy and perlitic textures found in the Hayden Valley flow, in addition to the rhyolite exposed above fluvial and lacustrine sediments, suggest the $0.102 \pm$ 0.004-Ma Hayden Valley flow (Obradovich, 1992) may have been emplaced when a lake (probably glacially dammed) occupied the valley (Richmond, 1976; Christiansen, 2001). Stable isotopic data confirm that the hydration water was very low in $\delta \mathrm{D}$ and therefore glacial in origin (Bindeman and Lowenstern, 2016). Studies of lake sediments north of Yellowstone Lake indicate that ancestral Yellowstone Lake extended north throughout the Hayden Valley and into the Pelican Valley (fig. 41).

To the east, sections of both Lava Creek Tuff members A and B are exposed due to uplift of the Sour Creek Dome. 7.2

15.4 Arrive at Canyon Junction. Turn east on South Rim Drive. $\mathbf{1 . 1}$

16.5 Stop at Artist Point parking lot (Stop 14). 


\section{Stop 14. Grand Canyon of the Yellowstone}

The dramatic yellow, orange, and red rocks and sediments in the canyon are a result of hydrothermal alteration of postcaldera volcanic rocks. The outcrops in the incised canyon provide a unique opportunity to view the exposure of what was once the subsurface portion of a significant thermal basin.

The Grand Canyon of the Yellowstone (figs. 41, 46) is $28 \mathrm{~km}$ long, extending from the Lower Falls to the Tower Falls area. It is about 250 to $350 \mathrm{~m}$ deep and 450 to $1,200 \mathrm{~m}$ wide. The Upper Falls is $33 \mathrm{~m}$ high and the Lower Falls is $94 \mathrm{~m}$ high. The valley is distinctly V-shaped, even though thick ice occupied the area during the Pinedale glaciation, which occurred from 30 to $10 \mathrm{ka}$,
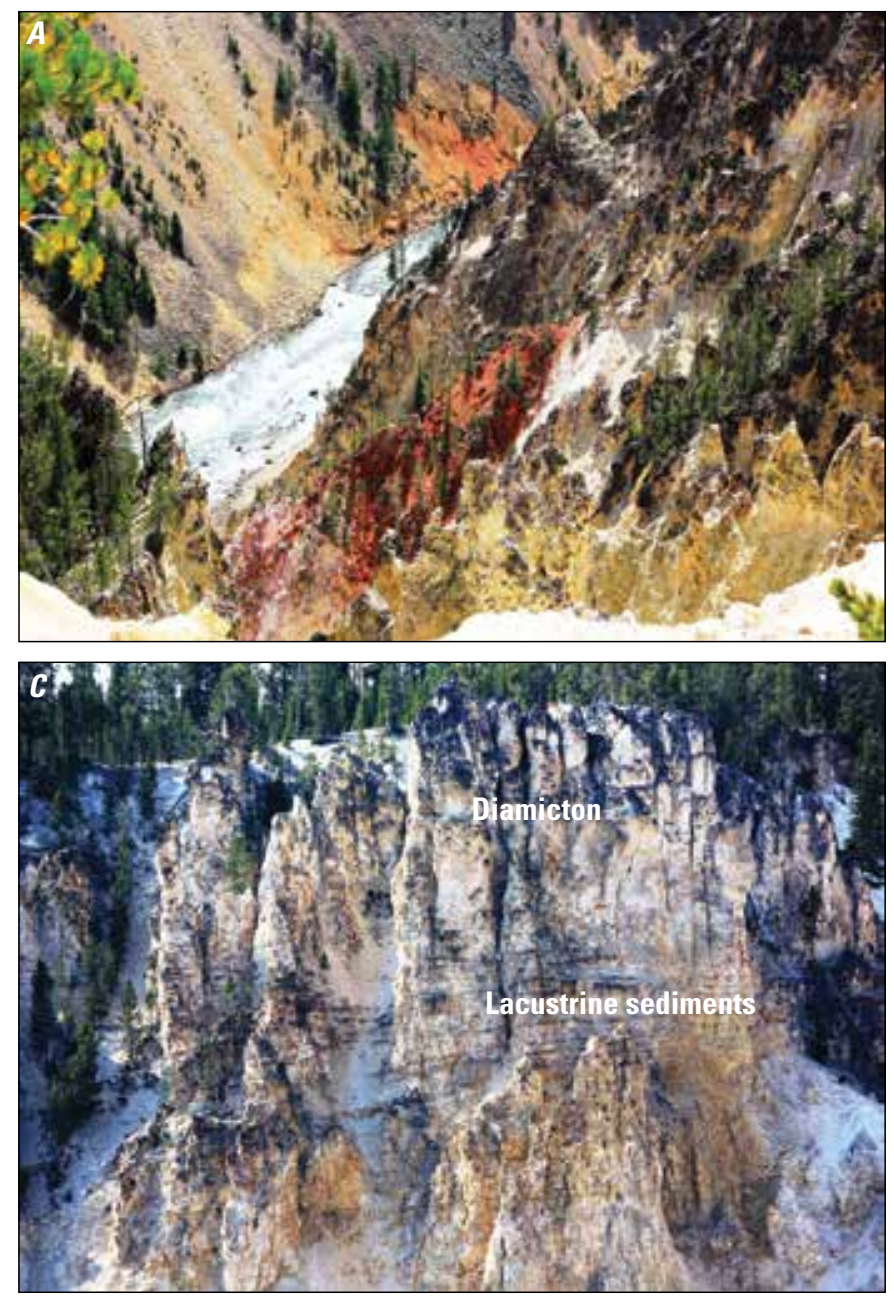

with its maximum at about $22 \mathrm{ka}$. Pierce (1979) suggests that, during glacial melting and retreat, an ice dam at Yellowstone Lake burst about 18 to $14 \mathrm{ka}$ and produced major floods that eroded the canyon. The area of the falls is also influenced by several faults that may have aided erosion. Finally, it is obvious that hydrothermal alteration of the rocks below the Lower Falls made them more susceptible to erosion, as evidenced by the abundant talus debris flows in the canyon now, including red-orange-yellow fine-grained material.

Rocks incised by the Yellowstone River and exposed in the walls of the Grand Canyon of the Yellowstone are in the Upper Basin Member of the Plateau Rhyolite (table 1) (Christiansen, 2001). Geochronology by Gansecki and others (1996) using
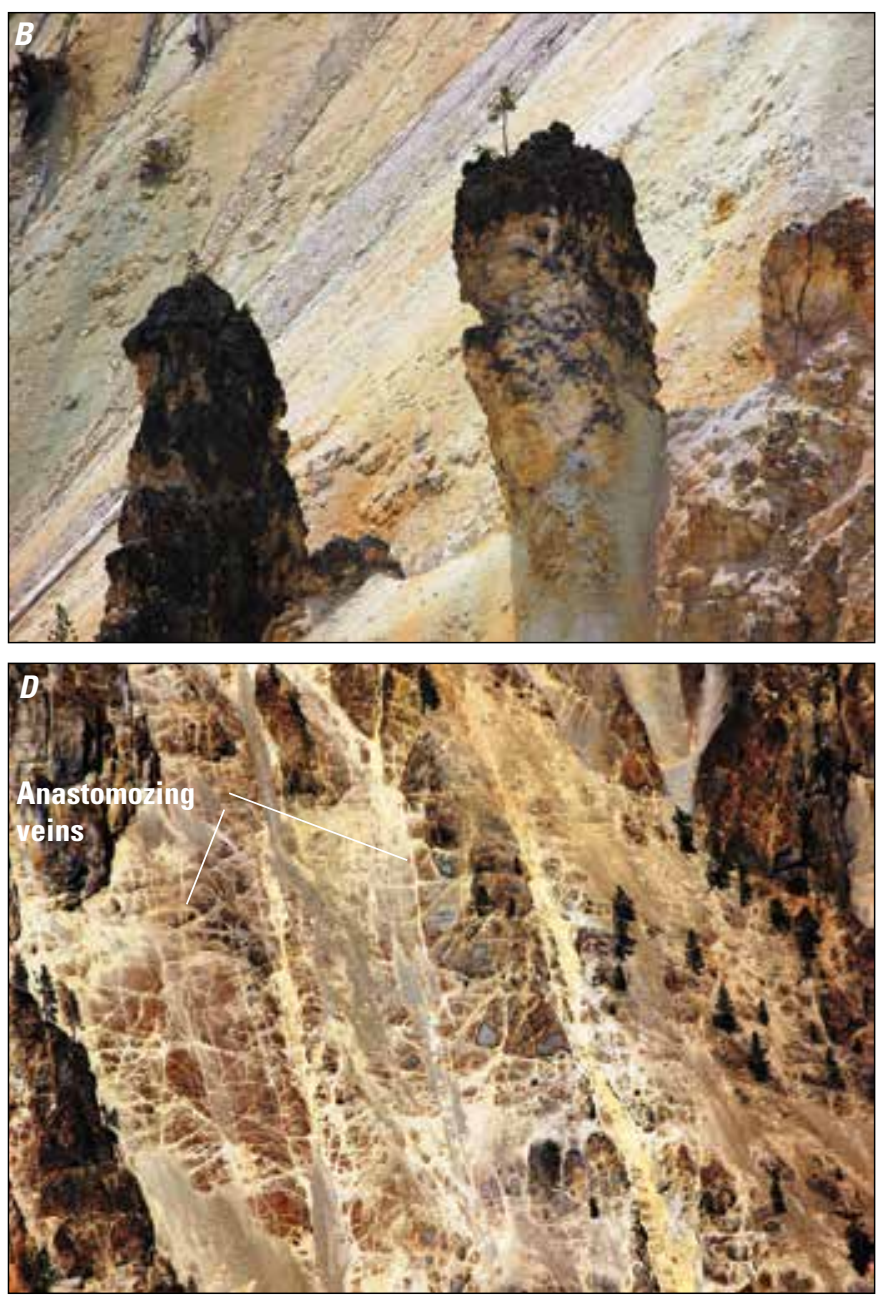

Figure 46. Photographs of hydrothermally altered rocks below Lower Falls in Grand Canyon of the Yellowstone (Stop 14). A, General view to the east of the Grand Canyon of the Yellowstone showing red, orange, and yellow sediments on the slopes derived from hydrothermally altered rocks. Hoodoos or pipe-like features that are resistant to erosion are located in the lower right (close-up photo of pipe-like features are shown in $B$ ). These features have coalesced into a linear chain of pipes that formed along a structure or fracture. Christiansen (2001) suggests that the pipe-like features cut the entire section and are fumarolic in origin. The width of the photo is approximately 50 meters across. $B$, Close-up photo of pipe-like features shown in $A$. C, Photograph looking north at an exposure of the sediments of Lower Falls (unit Qso on fig. 41) with a well cemented diamicton overlying a bedded lacustrine unit (Christiansen and Blank, 1975; Richmond, 1976). D, Photograph of a stockwork alteration zone in the west wall of the canyon just below Lower Falls, which represents a feeder zone for ascending hydrothermal fluids. Alteration includes anastomosing silica-filled veins with intermediate argillic alteration (includes quartz, illite, and adularia). 
${ }^{40} \mathrm{Ar}{ }^{\beta 9} \mathrm{Ar}$ techniques indicate similar ages for the Canyon flow $(0.484 \pm 0.015 \mathrm{Ma}$, table 1 ; and unit Qpuc in fig. 41) and the tuff of Sulphur Creek $(0.479 \pm 0.010 \mathrm{Ma}$, table 1; and unit Qpus in fig. 41). The tuff of Uncle Tom's Trail (unit Qput in fig. 41) has not been dated, but based on field, petrological, and geochemical studies, Pritchard and Larson (2012) argue that the tuff of Sulfur Creek and the tuff of Uncle Tom's Trail are the same unit. Typical of some early postcaldera rhyolites in Yellowstone, all of the Upper Basin Member units have anonymously low $\delta^{18} \mathrm{O}$ values compared to most Yellowstone National Park rhyolitic pyroclastic and lava flows. Melting of felsic rocks that were previously altered by meteoric water is the likely cause of the low $\delta^{18} \mathrm{O}$ values, which average about 5 per mil lower than normal (Hildreth and others, 1984, 1991; Bindeman and Valley, 2000, 2001).

Also exposed in the Grand Canyon of the Yellowstone area are the older Pleistocene sediments at Lower Falls (unit Qso in fig. 41), described by Richmond (1976) as diamicton that overlies a bedded lacustrine unit; both overlie the tuff of Sulphur Creek (or the tuff of Uncle Tom's Trail) in places (fig. 46). The Canyon flow directly overlies the tuff of Sulphur Creek in other places where the diamicton is absent. The diamicton may have formed as glacial till, as talus, or as a lacustrine tuffaceous olistostrome (Richmond, 1976).

On the east flank of the Grand Canyon of the Yellowstone, south and southeast of the Artists Point parking area, is an area of hummocky, hydrothermally cemented ice-contact deposits (also called thermal kames; unit Qhi in fig. 41) deposited due to localized glacial ice-melting above an area of sustained hydrothermal activity. The deposits are hydrothermally altered and cemented deposits of stratified or unstratified drift comprised of gravel and sand.

Features of hydrothermal alteration and mineralization within the Grand Canyon of the Yellowstone below Lower Falls include bright yellow, orange, and red hydrothermally altered rocks (sediments), or separate (sometimes linear) occurrences of pipe-like features (hoodoos) that stand as erosional remnants (fig. 46A). Additionally, bedded lacustrine and diamicton deposits of the sediments of Lower Falls (fig. 46B) are well exposed in the canyon. Stockwork alteration cuts altered rhyolite with anastomosing silica-filled veins (fig. 46C). Christiansen (2001) suggests that the pipe-like features cut the entire section and are fumarolic pipes. The stockwork alteration observed in lower parts of the canyon is well known from studies of volcanogenic massive sulfides (Shanks and Thurston, 2012) and other ore-forming systems. Stockwork veins represent the feeder zones for upwelling hydrothermal fluids where a combination of dissolution, alteration, fracturing, and mineralization have created permeability for fluid ascent.

The strongly altered rocks in the Grand Canyon of the Yellowstone observed from the south rim extend 3 to $4 \mathrm{~km}$ downstream to the northeast. Along the river about $9 \mathrm{~km}$ northeast of Lower Falls, extinct and active hydrothermal systems in the Seven Mile Hole area at the margin of the Yellowstone Caldera have been studied by Larson and others (2009). Results show that hydrothermal alteration of high-silica rhyolite produces adularia, clay minerals, silica minerals, disseminated pyrite and marcasite, zeolite minerals, iron oxides, native sulfur, and sulfate minerals (Andersen, 2010; Manion, 2010; Phillips, 2010). A distinct zoning at Seven Mile Hole is apparent where the upper $\sim 100 \mathrm{~m}$ in the canyon hosts advanced argillic minerals (opal and chalcedony, kaolinite and dickite, alunite and minor barite, and disseminated pyrite and marcasite) due to alteration by acid-sulfate fluids at temperatures below $\sim 150^{\circ} \mathrm{C}$. Deeper in the canyon, an intermediate argillic assemblage of quartz, illite, and adularia formed by reaction of rhyolitic rocks with alkalinechloride fluids at temperatures above $\sim 150^{\circ} \mathrm{C}$ (Larson and others, 2009). Geochronology using ${ }^{40} \mathrm{Ar} /{ }^{39} \mathrm{Ar}$ techniques on alunite indicate this system has been active since at least $0.154 \mathrm{Ma}$ (Larson and others, 2009).

15.4 Head to Wapiti Lake trailhead and picnic tables and eat lunch. After lunch, return west on South Rim Drive to Grand Loop Drive and turn north toward Canyon Village (fig. 1). 2.3

17.7 Stop at Canyon Visitor Education Center. You are on your own to investigate the exhibits and shopping opportunities. This is a good opportunity for a restroom stop as well.

Head back south on Grand Loop Drive toward Lake Village. 5.8

23.5 Before Lake Village, arrive at the trailhead to Crater Hills (fig. 41). We will hike $3 \mathrm{~km}$ round trip to Stop 15 through a meadow to a thermal area located about $2 \mathrm{~km}$ west of the Grand Loop Road as it passes through Hayden Valley.

\section{Stop 15. Crater Hills}

Crater Hills is a solitary thermal area with fumaroles, acid springs, and mixed acid-chloride waters. Care should be taken in approaching this backcountry thermal area, which requires traversing bear- and bison-frequented terrain. Visitors should follow precautions for avoiding conflicts with wildlife and to ensure the preservation of delicate thermal features.

Crater Hills is located within the area covered by the $0.102 \pm 0.004-M a$ Hayden Valley flow (fig. 47) and consists of a muted and hummocky surface that is expressed in the gently rolling landscape. As we walk toward Crater Hills, we will pass exposures of the Hayden Valley flow.

At Crater Hills (fig. 47A), fluvial-sorted gravels of rhyolite and obsidian fragments are cemented by opal (Allen and Day, 1935). In the southern and eastern parts of the thermal area, most features are fumaroles, frying pans, and acid muddy pools (fig. 47B). Noticeably different is the 6-m-diameter Sulphur Spring (fig. 47C), which emerges at the western base of cemented kame 

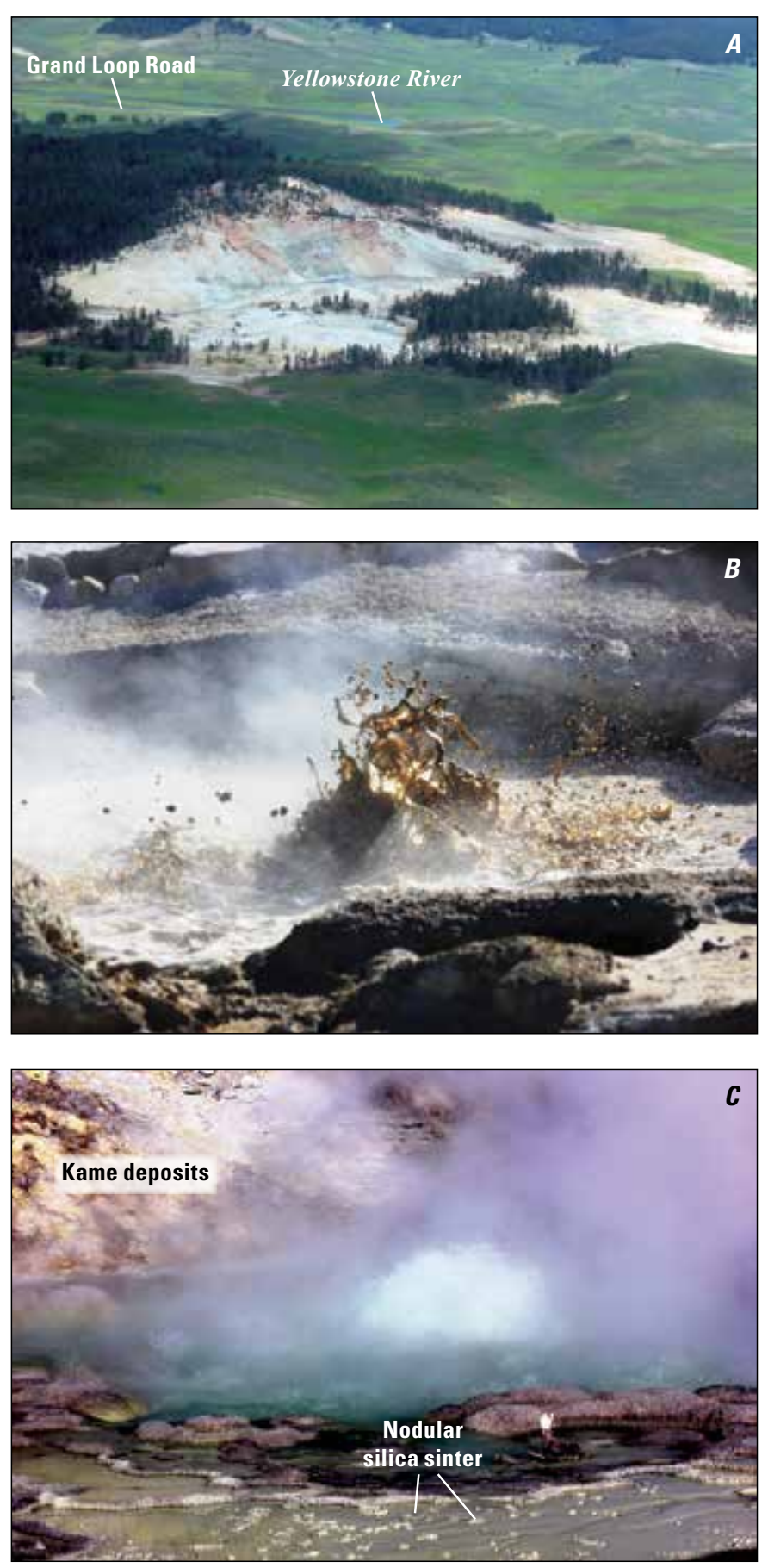

Figure 47. Photographs of the Crater Hills thermal area (Stop 15). $A$, Aerial view to the northeast showing intense hydrothermal alteration on the west side of Crater Hills. Notice Grand Loop Road and Yellowstone River beyond Crater Hills in the southern Hayden Valley. Photograph by Ken McGee, U.S. Geological Survey. B, Photograph of a low viscosity mudpot in the southern, acid-sulfate area of the Crater Hills field. $C$, Photograph of Sulphur Spring Geyser with altered and silica-cemented thermal kame deposits in the background and nodular, silica sinter deposition in the foreground. deposits within a broad area of bare, acid-altered terrain. Measured temperatures are typically 86 to $89^{\circ} \mathrm{C}$ in this frequently geysering and constantly agitated pool (Allen and Day, 1935; Fournier, 1989).

The chemistry of Sulphur Spring is unusual, with the highest measured $\mathrm{Cl}^{-}$concentrations in the park of 816 milligrams per liter, but also relatively high $\mathrm{SO}_{4}$ of 463 milligrams per liter and an acidic $\mathrm{pH}$ of 3.89 (figs. 13, 14; table 3). The high $\mathrm{SiO}_{2}$ and low $\mathrm{Na} / \mathrm{K}$ indicate the highest subsurface water temperatures at Yellowstone based on chemical geothermometry (Fournier and Truesdell, 1973). Fournier (1989) speculated that Sulphur Spring represents the most direct leakage of deep water anywhere in the system on the Yellowstone Plateau. Complicating matters, though, the $\delta \mathrm{D}$ and $\delta^{18} \mathrm{O}$ are consistent with evaporative concentration, which could contribute to the notably high solute concentrations. Allen and Day (1935) reported that minimal thermal water leaves the Crater Hills, and estimated that no more than 0.3 liter per second drains Sulphur Spring. He isotopes at Sulphur Spring (fig. 16) are among the highest at Yellowstone, with ${ }^{3} \mathrm{He} /{ }^{4} \mathrm{He}$ ratios $(10 \mathrm{R} / \mathrm{Ra})$, slightly less than the Gibbon Geyser Basin. Lin and others (2015) estimated a $\mathrm{CO}_{2}$ flux of 66 to 109 tons per day from this relatively small thermal area, about 30 percent of the discharge from neighboring Mud Volcano. Given the intense degassing and heat flow from this spring, its chemistry may be affected by both evaporation and mixing with acid condensate.

Return to the trail head.

23.5 Leave the Crater Hills area. Drive south on Grand Loop Road, turn left at Lake Village to Lake Lodge. 11.2

34.7 Arrive at Lake Lodge, where we will stay overnight. We will move tomorrow to Chico Hot Springs.

\section{Day 6: Lake Village to Caldera Overlook on Flanks of Mount Washburn, Calcite Springs Overlook, Lava Creek Tuff at Lost Creek, and Mammoth Hot Springs Terraces Finishing at Chico Hot Springs (Fig. 48)}

\section{Leave Lake Lodge at 7:30 a.m.}

Drive north of Lake Village (figs. 1, 41) along the Grand Loop Road paralleling the Yellowstone River (see description of the same stretch of road from day 5). As we continue across Hayden Valley (fig. 41), notice the highly eroded Eocene stratovolcanoes of the Washburn Range to the north. Continuing north, we leave the Hayden Valley, continuing to follow the Yellowstone River, now channeled where it cuts along the contact between the Solfatara Plateau flow to the west and the Hayden Valley flow to the east (fig. 41). The former is a subaerial lava flow that forms steep slopes and consists 


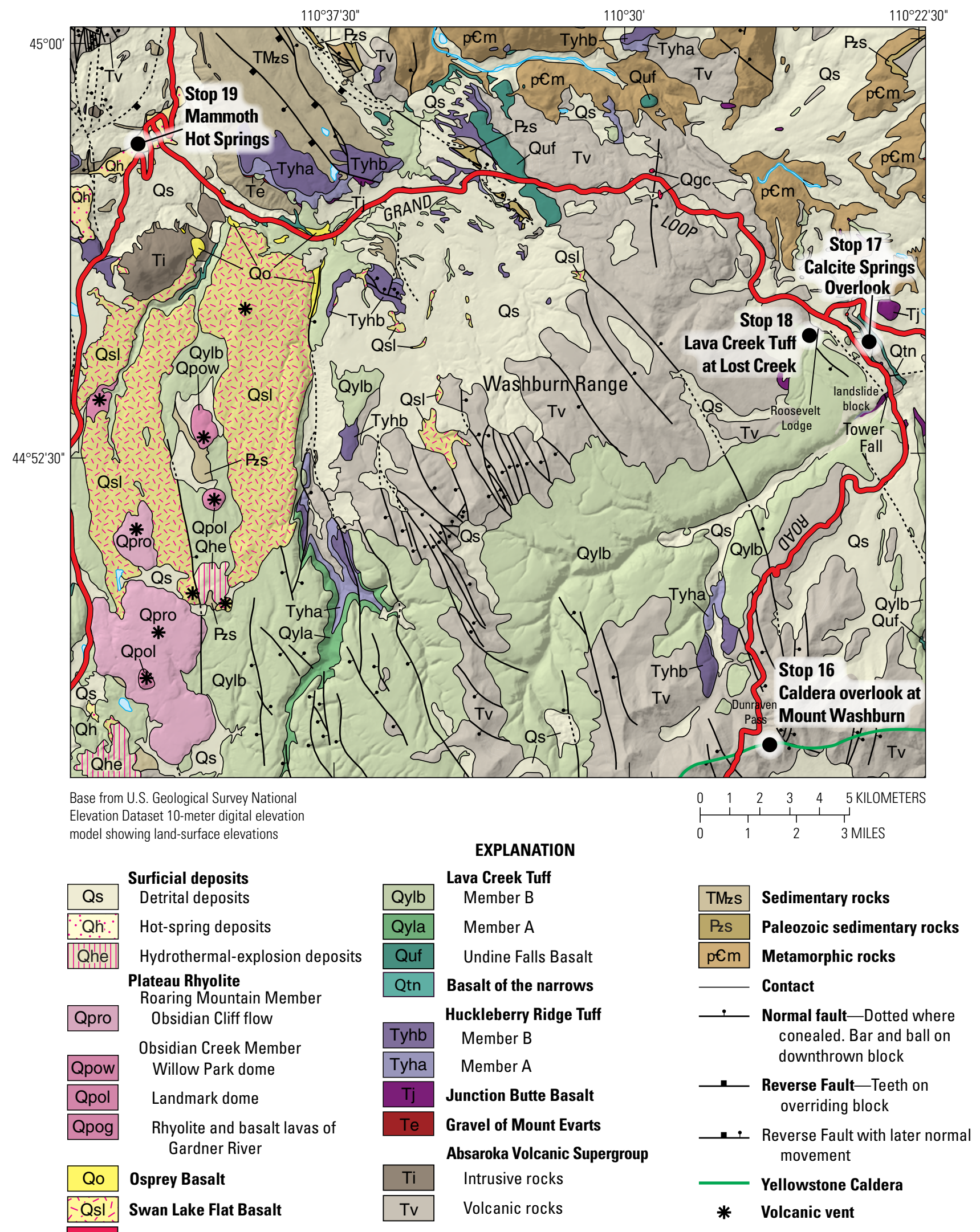

Figure 48. Geologic map and field trip stops on day 6. Stops include Caldera Overlook at Mount Washburn (Stop 16), Calcite Springs Overlook (Stop 17), Lava Creek Tuff at Lost Creek (Stop 18), and Mammoth Hot Springs (Stop 19). The main road is shown by the heavy red line. Geology by R.L. Christiansen (2001). 
of a series of thick, well-defined, dense individual flow units. In contrast, the Hayden Valley flow is exposed along the east bank of the Yellowstone River as gentle receding slopes composed of highly fragmented and incompetent perlitic rhyolite.

Continue north of the Grand Canyon of Yellowstone intersection (figs. 1, 41) while driving through monotonous lodgepole pine forests. As we continue north, look for a change in tree type from lodgepole pine to a more diverse forest of cedar, spruce, aspen, and other species. At that point, we cross from the northern topographic margin of the Yellowstone Caldera north to Tertiary volcanic terrain formed from 54 to $47 \mathrm{Ma}$. The diversity in vegetation (Pierce and others, 2007) is a reflection of the more nutrient-rich soil derived from mostly andesitic to trachytic volcanic rock compositions compared to the nutrient-poor soils produced from decomposition of high-silica rhyolites. 21.4

21.4 Enjoy the view to the south of the Yellowstone Caldera from the Washburn Overlook near Dunraven Pass (fig. 48).

\section{Stop 16. Caldera Overlook at Mount Washburn (Figs. 48, 49)}

The parking area is on the south-facing slope of Mount Washburn, a massive Tertiary (Eocene) stratovolcano associated with subduction-related volcanism around 54 to $47 \mathrm{Ma}$ and composed of andesitic to basaltic lava flows, dikes, debris flows, and subordinate ignimbrites (Feeley and others, 2002).

From Caldera Overlook at Mount Washburn, just south of Dunraven Pass, we have an excellent overview into the Yellowstone Caldera from its northern rim (fig. 49). Yellowstone Caldera is one of the largest calderas in the world at $\sim 75 \mathrm{~km}$ long (northeast to southwest) by $\sim 45 \mathrm{~km}$ wide (northwest to southeast). Looking south across the shorter dimension, Mount Sheridan and Flat Mountain (fig. 49) mark the southern margin of the third cycle caldera. Looking southeast into the Yellowstone Caldera, we can see the Grand Canyon of the Yellowstone. Here, the river cuts through the $0.479 \pm 0.010$-Ma tuff of Sulfur Creek (Gansecki and others, 1996) and the $0.484 \pm 0.015$-Ma Canyon flow (table 1). Sour Creek Dome, the Yellowstone Caldera rim, and other caldera features also are visible from here.

The view southward into the caldera includes the Yellowstone Plateau (fig. 1), a topographically high landscape of younger $(<0.200 \mathrm{Ma})$ postcaldera rhyolite lava flows that fill the collapsed Yellowstone Caldera. The morphology of these units is distinctive in their steep flow fronts, hummocky tops, and vast aerial extent.

To the east is the Absaroka Range, many peaks of which are eroded remnants of large stratovolcanoes similar to Mount Washburn. On a clear day, one can see Yellowstone Lake to the south, Flat Mountain, and Mount Sheridan. Farther south, the Teton Range can be seen.
22.8 Return to vehicles and head north on Grand Loop Road toward Tower Fall (fig. 48). As we approach Calcite Springs Overlook, observe the orientation of the tall Douglas firs on the hillside to the west (discussed below). 14.5

\subsection{Arrive at Calcite Springs Overlook (fig. 50). 1.9}

\section{Stop 17. Calcite Springs Overlook}

Park and walk up the boardwalk to get an excellent view of (1) the canyon cut by the Yellowstone River; (2) extracaldera hydrothermal spring activity along the canyon floor; and (3) exposures of the Junction Butte Basalt, dated to 2.1 Ma, and the "Basalt of the narrows," dated to 2 to $1.3 \mathrm{Ma}$, related to first- and second-cycle caldera-forming volcanism of the Yellowstone Plateau volcanic field, respectively (Christiansen, 2001) (fig. 50).

Calcite Springs is exposed at the base of the Yellowstone Canyon and is located above highly altered Eocene intermediate composition rocks with steep, unstable slopes. Across the road to the west from the Calcite Springs parking lot is a landslide block marked by a series of faults representing landslide scarps. Note that many of the large Douglas fir trees on this slope are tilted, some as much as $47^{\circ}$. Tree-ring analyses show an abrupt reduction in growth rate of Douglas firs starting at 1696 C.E. and this is inferred to represent a large earthquake event (Carrara, 2007). 1.9

39.2 Return to vehicles and continue north and west on the Grand Loop Road. Turn left into Tower-Roosevelt area (fig. 1).

\section{Stop 18. Lava Creek Tuff at Lost Creek}

Park in front of Roosevelt Lodge and proceed to the Lost Creek Falls trailhead (behind Roosevelt Lodge) south of the parking area. Follow the trail about $0.5 \mathrm{mi}$, climbing toward Lost Creek Falls to outcrops of Lava Creek Tuff member B in Lost Creek canyon.

Lava Creek Tuff member A is missing in this area; member B overlies Tertiary volcanic rocks of the Eocene Absaroka Supergroup (Christiansen, 2001). Typical Lava Creek Tuff member B exposures in this area are 40 to $50 \mathrm{~m}$ thick and roughly columnar in structure (fig. 51). They include a thin basal vitrophyre overlain by a thick spherulitic, vapor-phased lithophysal zone with lenticular cavities as long as $15 \mathrm{~cm}$, which is overlain in turn by a thick devitrified zone that commonly includes roughly horizontal platy joints. Densely to moderately welded vitrophyre is common in the top of the section (not shown).

Lava Creek Tuff member B has phenocrysts of quartz, sanidine $\left(\mathrm{Or}_{50-55}\right)$, and occasional plagioclase $\left(\mathrm{An}_{20}\right)$. Accessory phenocrysts commonly include magnetite, ilmenite, clinopyroxene (ferroaugite), fayalite, chevkinite, and allanite. 


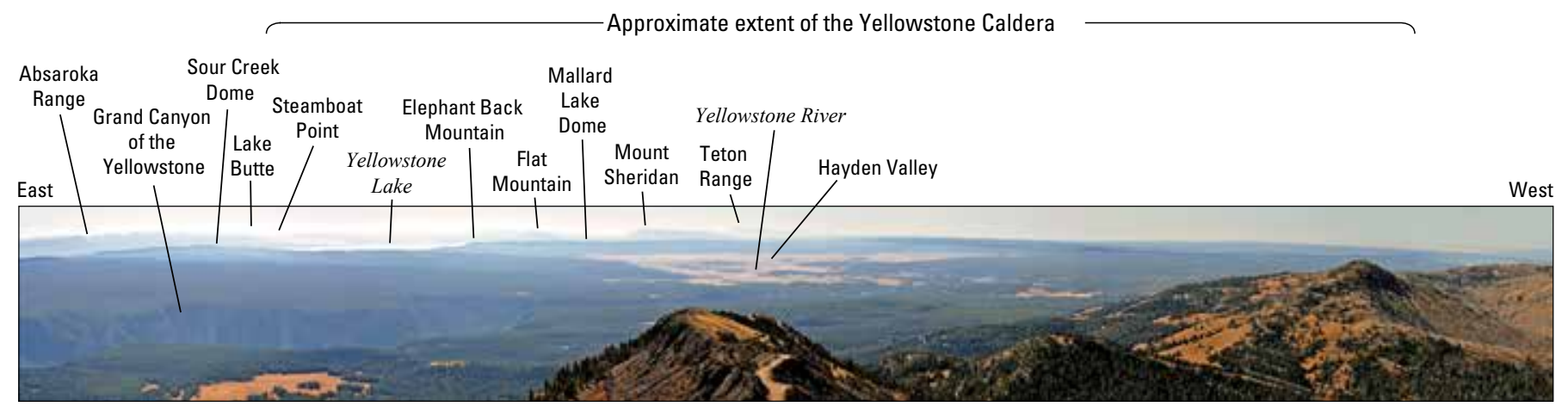

Figure 49. Panoramic photograph from Caldera Overlook at Mount Washburn (Stop 16). The photograph is looking south across the Yellowstone Caldera from Mount Washburn, a Tertiary (Eocene) stratovolcano. Many of the places and features visited during the field trip are identified in the photograph. Photograph from Dzurisin and others (2012).

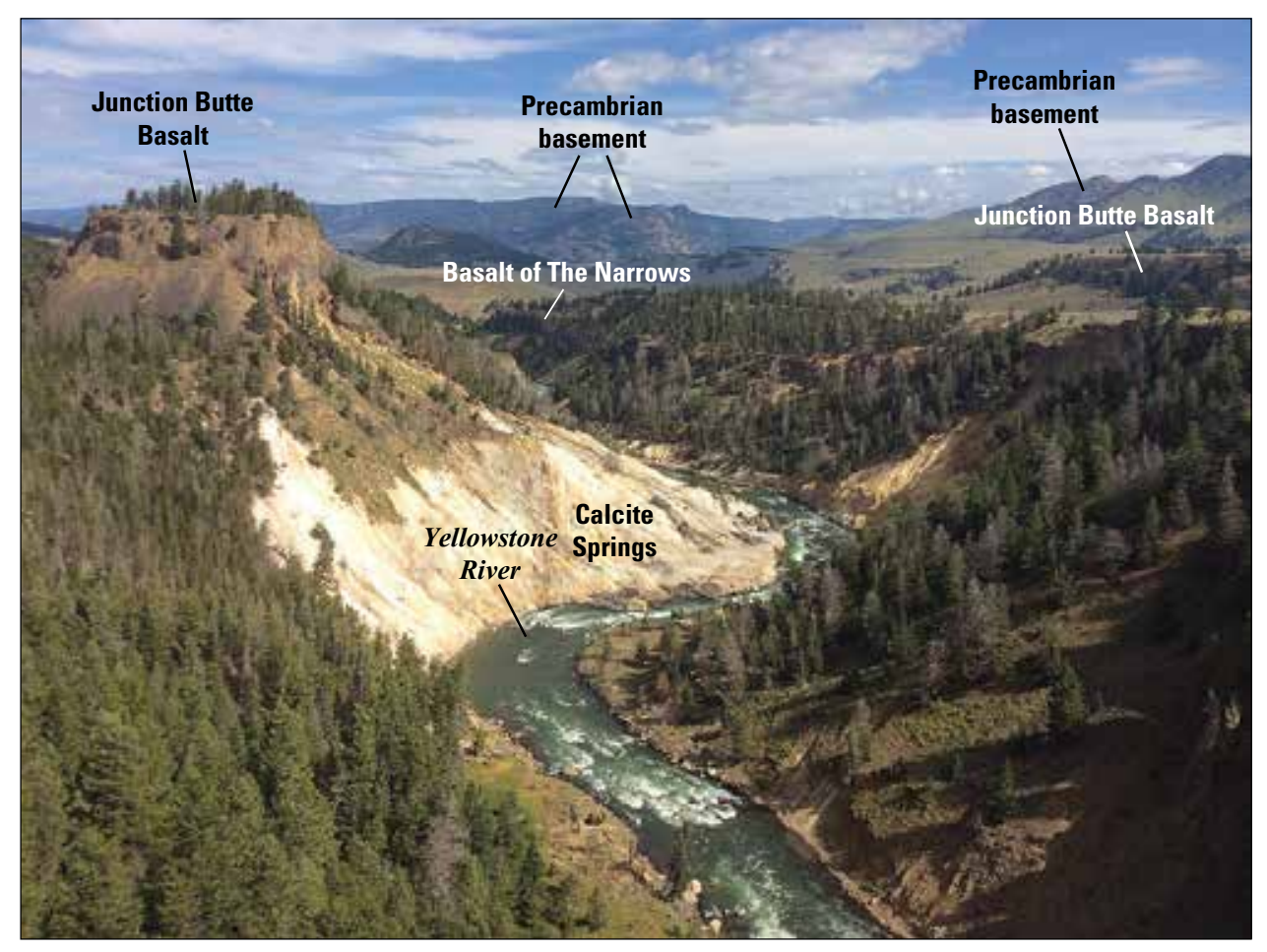

Figure 50. View looking northwest from Calcite Springs Overlook (Stop 17). Yellowstone River is shown in the lower-middle part of the photograph. The Junction Butte Basalt in the Tower Falls-Junction Butte area has been dated to $2.1 \mathrm{Ma}$ and underlies the Huckleberry Ridge Tuff of Yellowstone Group. Samples of the Basalt of The Narrows have been dated to 1.3 Ma. 

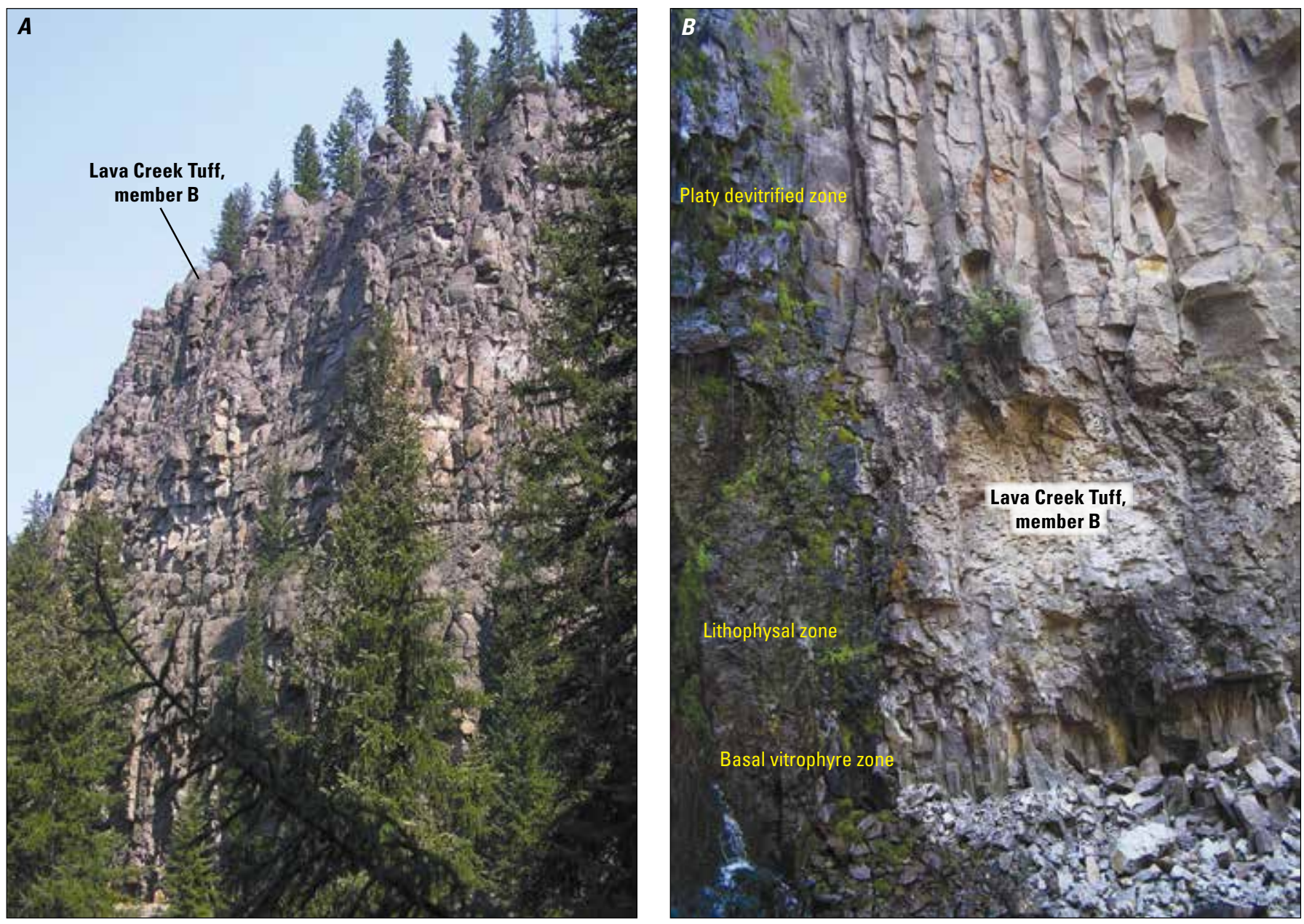

Figure 51. Photographs of an exposure of Lava Creek Tuff of Yellowstone Group at Lost Creek (Stop 18). A, View looking east of a 120-meter-thick section of Lava Creek Tuff (member B) along Lost Creek. B, Photograph of the lower section of the exposure of Lava Creek Tuff (member B) shown in $A$.

Hornblende is not present in Lava Creek Tuff member B but is common in Lava Creek Tuff member A.

Return to Roosevelt Lodge via the Lost Creek Falls trail. Return to vehicles and proceed west on the Grand Loop Road (U.S. Route 112) across northern Yellowstone National Park to Mammoth Hot Springs (figs. 48, 52). 31.5

57.0 Explore Mammoth Hot Springs.

Enter the boardwalks by foot at the upper parking area along the main road and walk generally north to the bottom of the terraces near Liberty Cap, where we will rejoin our vehicles. $\mathbf{0 . 5}$

\section{Stop 19. Mammoth Hot Springs}

Mammoth Hot Springs is the only major thermal area in Yellowstone National Park dominated by deposition of hydrothermal $\mathrm{CaCO}_{3}$ (travertine) rather than siliceous sinter.
The currently active Mammoth Hot Springs area (figs. 48, 52) is an elongate northeast-southwest depositional mound with an area of nearly $1 \mathrm{~km}^{2}$ that hosts approximately 100 active hot springs (Bargar, 1978). The total thickness of travertine deposits can be approximated using results from U.S. Geological Survey research drill hole Y-10, which was drilled near Bath Lake in 1967 to 1968 to a total depth of $113 \mathrm{~m}$. Travertine comprises the upper $77 \mathrm{~m}$ of the section, with Mesozoic limestones below the travertine (White and others, 1975).

Pierce and others (1991) and Sturchio and others (1994) report uranium-series age determinations on travertine. They found that Mammoth Hot Springs deposits have been active since $8.8 \mathrm{ka}$, whereas travertine deposits atop Terrace Mountain (fig. 52) to the southwest formed about $375 \mathrm{ka}$.

Rapid growth of travertine deposits at Mammoth Hot Springs has been identified since investigations by Allen (1934), who measured terrace buildup of 0.028 to 0.565 meters per year (Bargar, 1978). More recently, Houseal and others (2010) measured growth of 0.3 to $0.6 \mathrm{~m}$ in 10 months (1-2 millimeters 


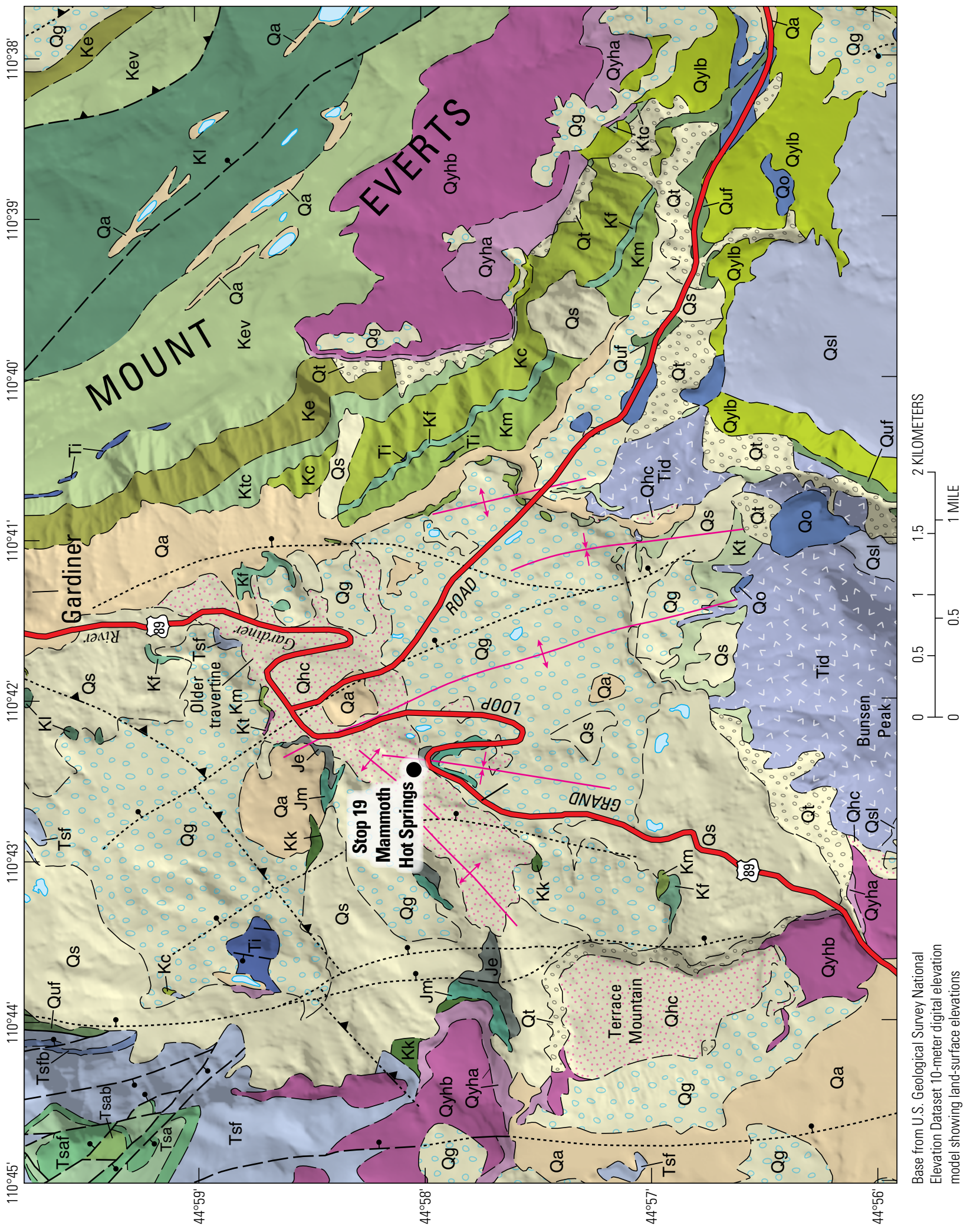

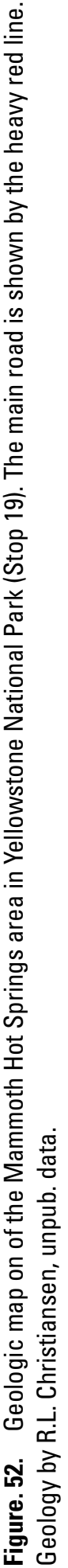




\begin{tabular}{|c|c|c|c|}
\hline \multicolumn{4}{|c|}{ EXPLANATION } \\
\hline & \multicolumn{2}{|l|}{ Surficial deposits } & \multirow{2}{*}{$\begin{array}{l}\text { Intrusive rocks } \\
\quad \text { Andesite sills and dikes }\end{array}$} \\
\hline \multirow[t]{2}{*}{ Qho } & \multirow{2}{*}{$\begin{array}{l}\text { Calcareous hot-spring deposits } \\
\text { (travertine) }\end{array}$} & $\mathrm{Ti}$ & \\
\hline & & $\operatorname{Tid}_{A}$ & Dacite stock of Bunsen Peak \\
\hline Qa & Alluvium and glaciofluvial deposits & $\mathrm{KI}$ & Landslide Creek Formation \\
\hline 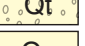 & Talus & Kev & \multirow{2}{*}{$\begin{array}{l}\text { Everts Formation } \\
\text { Eagle Sandstone }\end{array}$} \\
\hline Qs & Landslide deposits & $\mathrm{Ke}$ & \\
\hline Qg & Glacial deposits & Ktc & \multirow{2}{*}{$\begin{array}{l}\text { Telegraph Creek Formation of Montana Group } \\
\text { Cody Shale }\end{array}$} \\
\hline Qo & Osprey Basalt & Kc & \\
\hline Qsl & Swan Lake Flat Basalt & $\mathrm{Kf}$ & Frontier Sandstone \\
\hline Qylb & Member B & $\mathrm{Km}$ & Mowry Shale \\
\hline Quf & Undine Falls Basalt & $\mathrm{Kt}$ & \multirow{2}{*}{$\begin{array}{l}\text { Thermopolis Shale } \\
\text { Kootenai Formation }\end{array}$} \\
\hline & Huckleberry Ridge Tuff & Kk & \\
\hline Qyhb & Member B & $\mathrm{Jm}$ & Morrison Formation \\
\hline Qyha & Member A & Je & Ellis Group, undivided \\
\hline & $\begin{array}{l}\text { Sepulcher Formation of the Washburn Formation } \\
\text { of the Absaroka Volcanic Super Group }\end{array}$ & 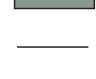 & Contact \\
\hline Tsa & Andesite lava flows & -1 & \multirow{2}{*}{$\begin{array}{l}\text { Approximately located normal fault- Dotted } \\
\text { where concealed. Ball and bar on downthrown } \\
\text { block }\end{array}$} \\
\hline \begin{tabular}{|c|} 
Tsaf \\
$T$
\end{tabular} & Key-bed lava flows & & \\
\hline Tsab & Flow breccia & $-\Lambda-$ & \multirow{2}{*}{$\begin{array}{l}\text { Approximately located thrust fault-Dotted } \\
\text { where concealed. Sawteeth on upper plate }\end{array}$} \\
\hline Tsf & Fortress Mountain Member & & \\
\hline Tsfb & \multirow[t]{2}{*}{ Basalt lava flow } & $\uparrow$ & \multirow{2}{*}{$\begin{array}{l}\text { Anticline } \\
\text { Syncline }\end{array}$} \\
\hline & & $\frac{\downarrow}{\uparrow}$ & \\
\hline
\end{tabular}

per day) at the Narrow Gauge hot spring. Detailed measurements of accumulation in different environments (facies) at Angel Terrace (fig. 53) indicate a growth rate of 0.1 to 5 millimeters per day, generally consistent with the Allen (1934) data. Of course, these locally measured accumulation rates are much more rapid than indicated by the $77 \mathrm{~m}$ of total accumulated thickness of the Mammoth Hot Springs deposits since $8.8 \mathrm{ka}$; average rate of accumulation is 0.00088 meters per year, or 0.024 millimeters per day. The difference can be explained by shifting hydrothermal vents and thermal water areas over time, as documented using historic and recent air photographs taken from 1954 to 2010 (Carr and others, 2010). Their time-series of shifting hydrothermal activity shows that the average area covered at a given time is 22,055 square meters (ranging from 8,500 to 32,900 square meters) and that the aggregate thermal water coverage of the Mammoth Hot Springs area over the 56 years of observation is about 35 percent.

The distinctive morphology of the terraces at Mammoth Springs reflects distributions of multiple pools within travertine rims arranged in stair-step fashion on the top and sides of the composite mound. Bargar (1978) and Allen and Day (1935) have grouped travertine terraces into three size categories that include terraces (tens of square meters), terracettes (a few square meters), and microterracettes (a few square centimeters or less). A typical travertine facies arrangement around a vent area at Angel Terrace is shown in figure $53 \mathrm{~A}$ and consists of vent, apron and channel, pond, proximal slope, and distal slope facies (Fouke and others, 2000).

Fouke and others (2000) report venting fluid temperatures of 71 to $73{ }^{\circ} \mathrm{C}$ and $\mathrm{pH}$ of 6 , with $\mathrm{CO}_{2}$ degassing and cooling downstream causing $\mathrm{CaCO}_{3}$ precipitation (fig. $53 \mathrm{~B}$ ). Fouke and others (2000) document deposition of aragonite in the vent, apron and channel, and pond facies, with calcite predominating at lower temperature and higher $\mathrm{pH}$ in the proximal and distal slope facies. Calcite also is commonly present in pond facies along with aragonite. Deposits formed at higher temperatures close to vents are predominantly aragonite needles and coatings on bacterial streamers, whereas calcite spherules, shrubs, and feathery crystals form in cooler distal areas downstream. An unusual feature in cooler, quiet areas is the formation of calcite "ice" that forms as a thin sheet at the surface of the pool.

Bargar (1978) has indicated that in addition to terracettes, prominent depositional geomorphologies include fissure ridges and mounds related to tension fractures, and cone shaped deposits up to 14 meters tall that develop above a stationary vent. De Filipis and Billi (2012) have recently studied fissure ridges at Mammoth Hot Springs and concluded that they form in the hanging-wall of normal faults with a common orientation of northeast-southwest. The ridges themselves are not offset by fault movement, but they often develop elongate central fissures that infill over time with dense banded travertine. In contrast, travertines in active depositional facies 


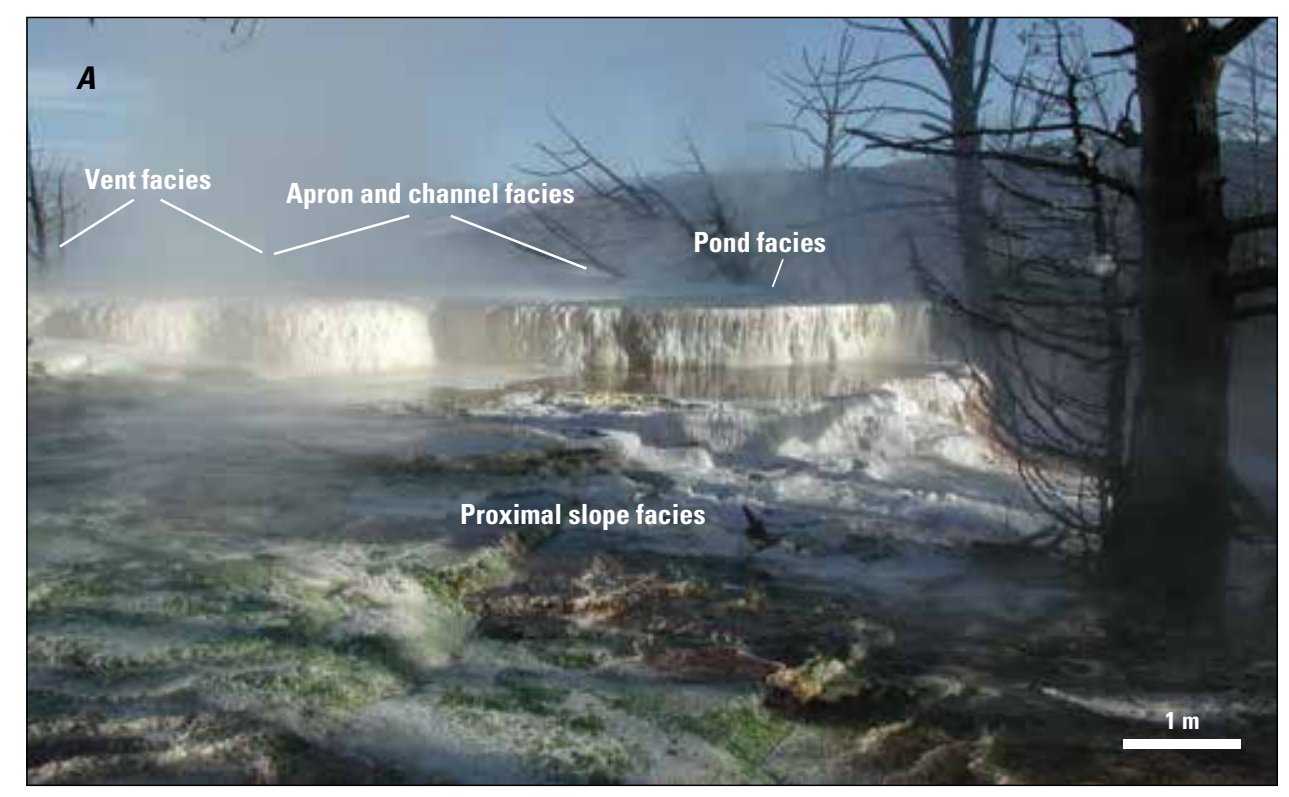

Figure 53. Photograph and facies diagram at Mammoth Hot Springs (Stop 6.4). A, Photograph looking southwest of Angel Terrace, showing the downstream facies succession from vent to apron to channel to pond to proximal slope facies. The facies at Angel Terrace are representative of active and inactive travertine areas in Yellowstone National Park and in Gardiner, Montana. B, Cross section and tabular data showing fluid temperature, $\mathrm{pH}$, mineralogy, and accretion rate of various terrace facies shown in $A$ (from Fouke, 2011). The distal slope facies shown in $B$ is not shown on the photograph in $A$. Abbreviations: ${ }^{\circ} \mathrm{C}$, degrees Celsius; $\mathrm{m}$, meters; mm, millimeters, Temp.; temperature.

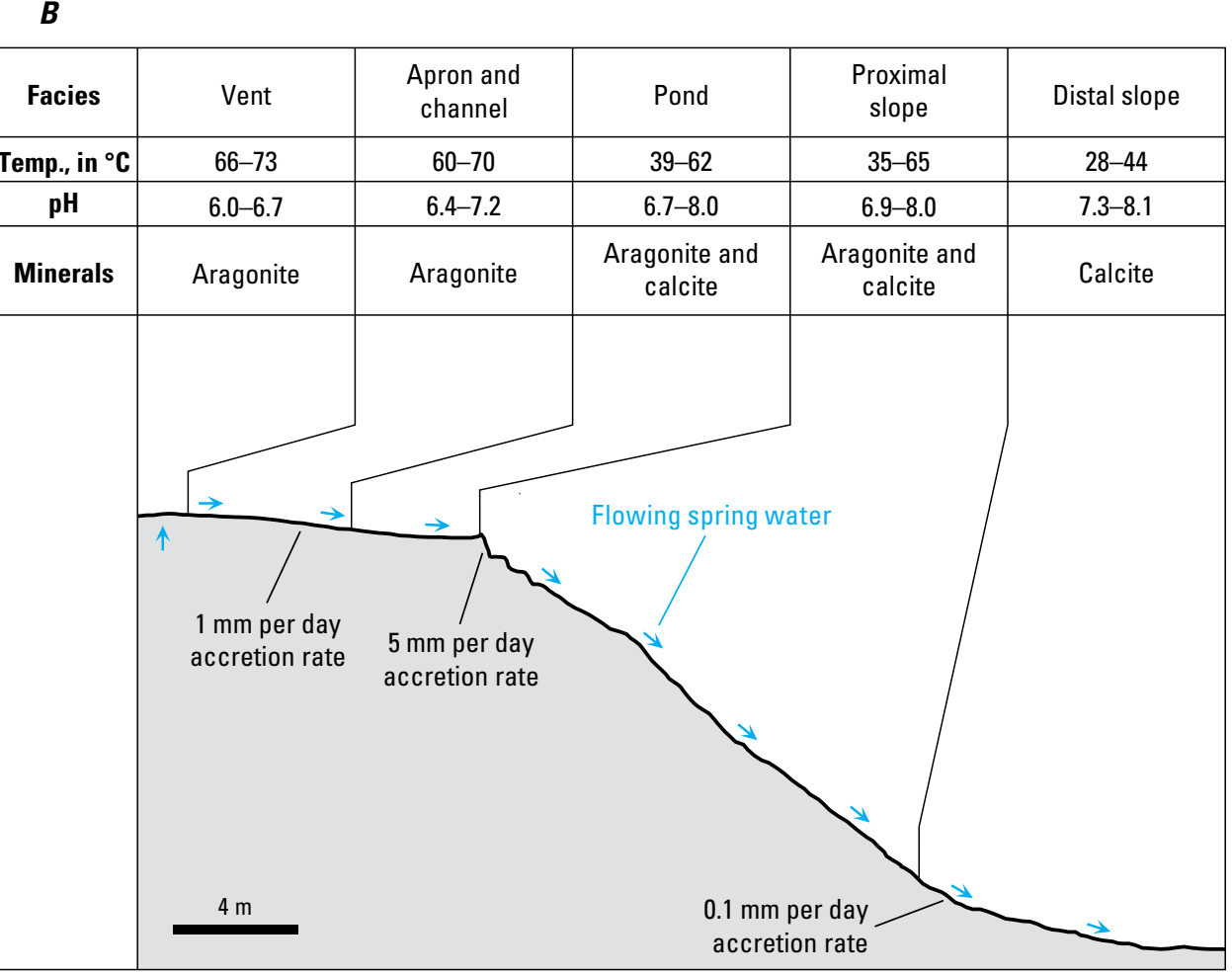

and on the flanks of fissure ridges are typically quite porous. Travertine at depth transforms into more massive forms by slow infill of porosity (Bargar, 1978). Vertical fractures and dissolution cavities (caves or grottos) are common in inactive areas.

The hydrothermal fluids at Mammoth Hot Springs (fig. 13) are cooler than many other areas in the park, with maximum temperatures of $\sim 73{ }^{\circ} \mathrm{C}$, and are $\mathrm{HCO}_{3}$-rich due to subsurface reaction with Paleozoic or Mesozoic limestones (Sturchio and others, 1994) and due to addition of magmatic
$\mathrm{CO}_{2}$. Carbon and helium isotope studies indicate that there are both magmatic and sedimentary carbon components in the Mammoth Hot Springs fluids (Kharaka and others, 2000; Sorey and Colvard, 1997). The hot spring fluids flow across and pool at the surface forming travertine deposits due to degassing of $\mathrm{CO}_{2}$, which produces an increase in $\mathrm{pH}$ by as much as 2 units (from $\mathrm{pH} 6$ to $\mathrm{pH} 8$ ), causing precipitation of $\mathrm{CaCO}_{3}$. Fluids are rich in $\mathrm{Ca}^{2+}, \mathrm{Mg}^{2+}, \mathrm{HCO}_{3}^{-}$, and $\mathrm{SO}_{4}^{2-}$ (figs. 13, 14). Water-rock interaction in the subsurface with Paleozoic and Mesozoic limestone presumably controls hot 
spring composition. The heat source is poorly constrained, but the Norris-Mammoth tectonic corridor (fig. 12) hosts multiple rhyolite and basalt vents that intruded through the sedimentary sequence, suggesting magmatic heat driving the system (Sorey and Colvard, 1997). Helium isotopes are notably higher here at Mammoth Hot Springs than $15 \mathrm{~km}$ south within the NorrisMammoth tectonic corridor (Kennedy and others, 1985).

Most of the thermal water from Mammoth Hot Springs re-enters the subsurface through karst terrain and re-issues along the Gardiner River in a series of springs known as Boiling River (Sorey and others, 1991), one of the two legal warm-water swimming holes in Yellowstone. Sulfide-oxidizing Aquificales bacteria contribute to the bright yellow, orange, and red coloration of the pools and channels. Detailed bacterial studies at Mammoth Hot Springs by Inskeep and others (2010) and Hamamura and others (2013) have shown that Aquificales bacteria are dominated by Sulfurihydrogenibium and S. yellowstonense, indicating metabolism dominated by sulfur oxidation utilizing $\mathrm{S}^{\circ}$ (elemental sulfur), $\mathrm{S}_{2} \mathrm{O}_{3}$, or $\mathrm{H}_{2} \mathrm{~S}$.

Fouke and coworkers (Kandianis and others, 2008) have addressed the issue of whether in situ $\mathrm{CaCO}_{3}$ precipitation is abiotic or biotic by conducting precipitation experiments in active channelways. They have shown that bacterial filaments provide a substrate where accumulation rates are much faster than on non-biological substrates. The cause of more rapid precipitation is not completely understood, but Kandianis and others (2008) have shown that rates are much slower (by more than one order of magnitude) when thermal waters are filtered to remove biomass prior to reaction with the abiotic substrate. In general, they conclude that bacteria are not directly mediating precipitation reactions, but rather are providing a favorable substrate. $\mathbf{0 . 5}$

57.5 Head to Gardiner by continuing north on U.S. Route 89. As we leave the Mammoth Hot Springs area, note the sheet-like units capping Mount Everts, the flat-topped mountain to the east. Here, both the 2.08Ma Huckleberry Ridge Tuff and the 0.63-Ma Lava Creek Tuff fill paleovalleys on top of Mount Everts, which is composed of Cretaceous strata dominated by carbonaceous shales (fig. 52). Note also the basal contact of the Huckleberry Ridge Tuff where the lower sedimentary units of the Cretaceous sequence have been oxidized by hot pyroclastic flows (Reynolds, 1977). As we approach Gardiner, note the basalt and travertine exposures to the north above the town. As we drive north from Gardiner, observe the basaltic dikes and continuous exposures of 2.2-Ma basalt (Smith and others, 1995). Absaroka Volcanic Supergroup units are exposed at higher elevations on both sides of the Paradise Valley (fig. 1, inset). From Gardiner, continue driving north on U.S. Route 89 up the Paradise Valley.

On the east side of the road, across the Yellowstone River, note the continuous exposure of the 2.2-Ma Hepburns Mesa Basalt (Smith and others, 1995) capping the hillslope. The Hepburns Mesa Basalt is similar in age to the initial phases of the YPVF. Olivine phenocrysts from this unit have ${ }^{3} \mathrm{He} /{ }^{4} \mathrm{He}$ ratios $>21 \mathrm{R} / \mathrm{Ra}$ (Pierce and others, 2014). Ratios above $8 \mathrm{R} / \mathrm{Ra}$ are commonly thought to indicate a deep mantle source, and thus support a deep mantle origin for the Yellowstone hot spot (Pierce and others, 2014), although other interpretations are possible (for example, Graham and others, 2009). The surface of this basalt is striated and polished by the Pinedale glaciation (Pierce and others, 2014). Below the basalt are white tuffaceous beds that dip 8 to $10^{\circ}$ into the Emigrant Fault and are Barstovian (15 Ma) in age (Burbank and Barnosky, 1990), similar in age to earliest caldera formation on the Snake River Plain.

Hepburns Mesa was used by Native Americans as a bison jump, a method for hunting bison by diverting and chasing them so they unwittingly jumped off the cliff and perished. Continue driving north on U.S. Route 89 along the Yellowstone River. Take East River Road to look at a dike sheet exposure. Turn east, continuing on East River Road toward Chico Hot Springs and drive through glacial moraines (unit Qg in fig. 52) (Pierce and others, 2014). $\mathbf{3 1 . 7}$

97.3 Arrive at Chico Hot Springs, where we will stay our final night.

\section{References Cited}

Abedini, A.A., 2009, Basalt petrogenesis and evolution in the Yellowstone Plateau Volcanic Field: Hayward, Calif., California State University, M.S. thesis, 140 p.

Abedini, A.A., Robinson, J.E., Muffler, L.J.P., White, D.E., Beeson, M.H., and Truesdell, A.H., 2015, Database for the geologic map of upper Geyser basin, Yellowstone National Park, Wyoming: U.S. Geological Survey Data Series 911, scale 1:4,800, accessed September 15, 2016 at https://doi.org/10.3133/ds911.

Allen, E.T., 1934, The agency of algae in the deposition of travertine and silica in thermal waters: American Journal of Science, ser. 5, v. 28 , no. 167 , p. $373-389$.

Allen, E.T., and Day, A.L. [Microscopic examinations by Merwin, H.E.], 1935, Hot Springs of the Yellowstone National Park: Carnegie Institute of Washington Publication 466, Washington, D.C., 525 p.

Anders, M.H., Geissman, J.W., Piety, L.A., and Sullivan, T.J., 1989, Parabolic distribution of circumeastern Snake River Plain seismicity and latest Quaternary faulting-Migratory pattern and association with the Yellowstone hotspot: Journal of Geophysical Research, v. 94, no. B2, p. 1,589-1,621. 
Anders, M.H., Rodgers, D.W., Hemming, S.R., Saltzman, J., DiVenere, V.J., Hagstrum, J.T., Embree, G.F., and Walker, R.C., 2014, A fixed sublithospheric source for the late Neogene track of the Yellowstone hotspot-Implications of the Heise and Picabo Volcanic Fields: Journal of Geophysical Research Solid Earth, v. 119, no. 4, p. 2,871-2,906, accessed September 20, 2016, at https://doi. org/10.1002/2013JB010483.

Andersen, A.K., 2010, Geochemistry of Inkpot Spring, Sulphur Creek-Sevenmile Hole area, Yellowstone Caldera, Wyoming: Pullman, Wash., Washington State University, M.S. thesis, 172 p., accessed August 5, 2016, at http://citeseerx.ist.psu.edu/viewdoc/download?doi=10.1.1.425.2122\& rep=rep $1 \&$ type $=$ pdf.

Armstrong, R.L., Leeman, W.P., and Malde, H.E., 1975, K-Ar dating, Quaternary and Neogene volcanic rocks of the Snake River Plain, Idaho: American Journal of Science, v. 275 , no. 3, p. 225-251. [Also available at http://www. ajsonline.org/content/275/3/225.citation.]

Balistrieri, L.S., Shanks, W.C.P., III, Cuhel, R.L., Aguilar, C., and Klump, J.V., 2007, The influence of sublacustrine hydrothermal vent fluids on the geochemistry of Yellowstone Lake, chap. F of Morgan, L.A., ed., Integrated geoscience studies in the greater Yellowstone area-Volcanic, tectonic, and hydrothermal processes in the Yellowstone geoecosystem: U.S. Geological Survey Professional Paper 1717, p. 173-199. [Also available at https://pubs.usgs.gov/pp/1717/.]

Ball, J.W., McCleskey, R.B., Nordstrom, D.K., Holloway, J.M., and Verplanck, P.L., 2002, Water-chemistry data for selected springs, geysers, and streams in Yellowstone National Park, Wyoming, 1999-2000: U.S. Geological Survey Open-File Report 02-382, 104 p. [Also available at https://pubs.er.usgs. gov/publication/ofr02382.]

Ball, J.W., McCleskey, R.B., Nordstrom, D.K., and Holloway, J.M., 2006, Water-chemistry data for selected springs, geysers, and streams in Yellowstone National Park, Wyoming, 20032005: U.S. Geological Survey Open-File Report 2006-1339, 137 p. [Also available at https://pubs.er.usgs.gov/publication/ ofr20061339.]

Ball, J.W., McCleskey, R.B., and Nordstrom, D.K., 2010, Water-chemistry data for selected springs, geysers, and streams in Yellowstone National Park, Wyoming, 20062008: U.S. Geological Survey Open-File Report 2010-1192, 109 p., accessed September 5, 2016 at https://pubs.er.usgs. gov/publication/ofr20101192.

Ball, J.W., Nordstrom, D.K., Cunningham, K.M., Schoonen, M.A., Xu, Y., and DeMonge, J.M., 1998b, Water-chemistry and on-site sulfur-speciation data for selected springs in Yellowstone National Park, Wyoming, 1994-1995: U.S. Geological Survey Open File Report 98-574, 35 p., accessed September 14, 2016, at https://pubs.er.usgs.gov/publication/ofr98574.
Ball, J.W., Nordstrom, D.K., Jenne, E.A., and Vivit, D.V., 1998a, Chemical analyses of hot springs, pools, geysers, and surface waters from Yellowstone National Park, Wyoming, and vicinity, 1974-1975: U.S. Geological Survey Open File Report 98-182, 45 p., accessed September 14, 2016, at https://pubs.er.usgs.gov/ publication/ofr98182.

Bargar, K.E., 1978, Geology and thermal history of Mammoth Hot Springs, Yellowstone National Park, Wyoming: U.S. Geological Survey Bulletin 1444, 55 p., 1 pl. [Also available at https://pubs. er.usgs.gov/publication/b1444.]

Bargar, K.E. and Fournier, R.O., 1988, Effects of glacial ice on subsurface temperatures of hydrothermal systems in Yellowstone National Park, Wyoming — Fluid-inclusion evidence: Geology, v. 16, no. 12, p. 1,077-1,080. [Also available at http://geology.gsapubs.org/content/16/12/1077. full.pdf + html.]

Bargar, K.E. and Muffler, L.J.P., 1982, Hydrothermal alteration in research drill hole Y-11 from a vapor-dominated geothermal system at Mud Volcano, Yellowstone National Park, Wyoming: Thirty-Third Annual Field Conference, 1982, Wyoming Geological Association Guidebook, p. 139-152. [Also available at http://archives.datapages.com/data/wga/data/039/039001/ pdfs/139.pdf.]

Befus, K.S., 2016, Crystallization kinetics of rhyolitic melts using oxygen isotope ratios: Geophysical Research Letters, v. 43, no. 2, p. 592-599, accessed August 1, 2016, at https://doi.org/10.1002/2015GL067288.

Befus, K.S., and Gardner, J.E., 2016, Magma storage and evolution of the most recent effusive and explosive eruptions from Yellowstone Caldera: Contributions to Mineralogy and Petrology, v. 171, no. 30, 19 p., accessed August 1, 2016, at https://doi.org/10.1007/s00410-016-1244-x.

Belousov, A., Belousova, M., and Nechayev, A., 2013, Video observations inside conduits of erupting geysers in Kamchatka, Russia, and their geological frameworkImplications for the geyser mechanism: Geology, v. 41, no. 3, p. 387-390. [Also available at https://doi.org/10.1130/ G33366.1.]

Benz, H.M., and Smith, R.B., 1984, Simultaneous inversion for lateral velocity variations and hypocenters in the Yellowstone region using earthquake and refraction data: Journal of Geophysical Research, v. 89, no. B2, p. 1,2081,220. [Also available at http://onlinelibrary.wiley.com/ doi/10.1029/JB089iB02p01208/pdf.]

Beranek, L.P., Link, P.K., and Fanning, C.M., 2006, Miocene to Holocene landscape evolution of the western Snake River Plain region, Idaho-Using the SHRIMP detrital zircon provenance record to track eastward migration of the Yellowstone hotspot: Bulletin of the Geological Society of America, v. 118, no. 9-10, p. 1,027-1,050. [Also available at https://doi.org/10.1130/B25896.1.] 
Bergfeld, D., Lowenstern, J.B., Hunt, A.G., Shanks, W.C.P., III, and Evans, W.C., 2011, Gas and isotope chemistry of thermal features in Yellowstone National Park, Wyoming: U.S. Geological Survey Scientific Investigations Report 2011-5012, 28 p. and data files. [Also available at https:// pubs.usgs.gov/sir/2011/5012/.]

Bindeman, I.N., and Lowenstern, J.B., 2016, Low-SD hydration rinds in Yellowstone perlites record rapid syneruptive hydration during glacial and interglacial conditions: Contributions to Mineralogy and Petrology, v. 171, no. 89, 24 p., accessed November 10, 2016, at https:// doi.org/10.1007/s00410-016-1293-1.

Bindeman, I.N., and Valley, J.W., 2000, Formation of low- $\delta{ }^{18} \mathrm{O}$ rhyolites after caldera collapse at Yellowstone, Wyoming, USA: Geology, v. 28, no. 8, p. 719-722. [Also available at http://geology.gsapubs.org/content/28/8/719. full.pdf + html.]

Bindeman, I.N., and Valley, J.W., 2001, Low- $\delta^{18} \mathrm{O}$ rhyolites from Yellowstone-Magmatic evolution based on analyses of zircons and individual phenocrysts: Journal of Petrology, v. 42, no. 8, p. 1,491-1,517. [Also available at https://doi. org/10.1093/petrology/42.8.1491.]

Bonnichsen, B., and Kauffman, D.F., 1987, Physical features of rhyolite lava flows in the Snake River Plain volcanic province, southwestern Idaho: Geological Society of America Special Paper 212, p. 119-145. [Also available at https://pubs.geoscienceworld.org/books/book/349/ chapter/3796389/Physical-features-of-rhyolite-lava-flowsin-the.]

Bonnichsen, B., Leeman, W.P., Honjo, N., McIntosh, W.C., and Godchaux, M., 2007, Miocene silicic volcanism in southwestern Idaho - Geochronology, geochemistry, and evolution of the central Snake River Plain: Bulletin of Volcanology, v. 70, no. 3, p. 315-342. [Also available at http://link.springer.com/article/10.1007/s00445-007-0141-6.]

Boyd, F.B., 1961, Welded tuffs and flows in the rhyolite plateau of Yellowstone Park, Wyoming: Bulletin of the Geological Society of America, v. 72, no. 3, p. 387-426. [Also available at http://bulletin.geoscienceworld.org/content/72/3/387.]

Braunstein, D., and Lowe, D.R., 2001, Relationship between spring and geyser activity and the deposition and morphology of high temperature $\left(>73^{\circ} \mathrm{C}\right)$ siliceous sinter, Yellowstone National Park, Wyoming, U.S.A.: Journal of Sedimentary Research, v. 71, p. 747-763, accessed May 4, 2016, at https://doi.org/10.1306/2DC40965-0E47-11D78643000102C1865D.

Brock, T.D., 1978, Thermophilic microorganisms and life at high temperatures: New York, Springer-Verlag, 465 p. [Also available at http://digicoll.library.wisc.edu/cgi-bin/Science/ Science-idx?id=Science.BrockTher.]
Browne, P.R.L., and Lawless, J.V., 2001, Characteristics of hydrothermal eruptions, with examples from New Zealand and elsewhere: Earth Science Reviews, v. 52, no. 4, p. 299-331. [Accessed June 12, 2004, at https://doi. org/10.1016/S0012-8252(00)00030-1.]

Bryan, T.S., 2008, The geysers of Yellowstone, 4th edition: Boulder, Colo., University Press of Colorado, 480 p.

Burbank, D.W., and Barnosky, A.D., 1990, The magnetochronology of Barstovian mammals in southwestern Montana and implications for the initiation of Neogene crustal extension in the northern Rocky Mountains: Geological Society of America Bulletin, v. 102, no. 8, p. 1,093-1,104, accessed May 6, 2000, at http://gsabulletin. gsapubs.org/content/102/8/1093.

Camp, V.E., Pierce, K.L., and Morgan, L.A., 2015, Yellowstone plume trigger for Basin and Range extension, and coeval emplacement of the Nevada-Columbia basin magmatic belt: Geosphere, v. 11, no. 2, p. 203-225. [Also available at http:// geosphere.gsapubs.org/content/11/2/203.]

Camp, V.E., and Ross, M.E., 2004, Mantle dynamics and genesis of mafic magmatism in the intermontane Pacific Northwest: Journal of Geophysical Research Solid Earth, v. 109, no. B8, 9 p., accessed November 6, 2005, at http:// agupubs.onlinelibrary.wiley.com/hub/issue/10.1002/jgrb. v109.B8/.

Carr, B.B., Jaworowski, C., and Heasler, H.P., 2010, It's not drying up, just changing-Mapping change at Mammoth Hot Springs using aerial photographs and visual observations: Yellowstone Science, v. 18, no. 3, p. 15-22. [Also available at https://www.nps.gov/yell/learn/upload/YS_18_3_sm.pdf.]

Carrara, P.E., 2007, Movement of a large landslide block dated by tree-ring analysis, Tower Falls area, Yellowstone National Park, Wyoming, chap. B of Morgan, L.A., ed., Integrated geoscience studies in the greater Yellowstone area-Volcanic, hydrothermal and tectonic processes in the Yellowstone geoecosystem: U.S. Geological Survey Professional Paper 1717, p. 41-52. [Also available at https://pubs.usgs.gov/ $\mathrm{pp} / 1717 /$.

Cathey, H.E., and Nash, B.P., 2004, The Cougar Point TuffImplications for thermochemical zonation and longevity of high-temperature, large-volume silicic magmas of the Miocene Yellowstone hotspot: Journal of Petrology, v. 45, no. 1, p. 27-58. [Also available at https://doi.org/10.1093/ petrology/egg081.]

Cathey, H.E. and Nash, B.P., 2009, Pyroxene thermometry of rhyolitic lavas of the Bruneau-Jarbridge eruptive center, Central Snake River Plain: Journal of Volcanology and Geothermal Research, v. 188, nos. 1-3, p. 173185. [Also available at http://dx.doi.org/10.1016/j. jvolgeores.2009.05.024.] 
Chaffee, M.A., Shanks, W.C.P., III, Rye, R.O., Schwartz, C.C., Carlson, R.R., Crock, J.G., Adams, M., Gemery, P.A., Gunther, K.A., Kester, C.L., King, H.D., and Podruzny, S.R., 2007, Applications of trace-element and stableisotope geochemistry to wildlife issues, Yellowstone National Park and vicinity, chap. J of Morgan, L.A., ed., Integrated geoscience studies in the greater Yellowstone area-Volcanic, hydrothermal and tectonic processes in the Yellowstone geoecosystem, U.S. Geological Survey Professional Paper 1717, p. 299-334. [Also available at https://pubs.usgs.gov/pp/1717/.]

Chang, W.L., Smith, R.B., Farrell, J., and Puskas, C.M., 2010, An extraordinary episode of Yellowstone Caldera uplift, 2004-2010, from GPS and InSAR observations: Geophysical Research Letters, v. 37, no. 23, 5 p., accessed July 2, 2012, at https://doi. org/10.1029/2010GL045451.

Chang, W.L, Smith, R.B., Wicks, C., Farrell, J.M., and Puskas, C.M., 2007, Accelerated uplift and magmatic intrusion of the Yellowstone Caldera, 2004 to 2006: Science, v. 318, no. 5852, p. 952-956, accessed March 19, 2015, at https:// doi.org/10.1126/science.1146842.

Chiodini, G., Caliro, S., Lowenstern, J.B., Evans, W.C., Bergfeld, D., Tassi, F., and Tedesco, D., 2012, Insights from fumarole gas geochemistry on the origin of hydrothermal fluids on the Yellowstone plateau: Geochimica et Cosmochimica Acta, v. 89, p. 265-278, accessed at http:// dx.doi.org/10.1016/j.gca.2012.04.051.

Christiansen, R.L., 1984, Yellowstone magmatic evolution; Its bearing on understanding large-volume explosive volcanism, in Explosive volcanism-Inception, evolution, and hazards: Washington, D.C., National Academy Press, p. 84-95.

Christiansen, R.L., 2001, The Quaternary and Pliocene Yellowstone Plateau Volcanic Field of Wyoming, Idaho, and Montana: U.S. Geological Survey Professional Paper 729-G, 145 p., 3 pls. [Also available at https://pubs.er.usgs. gov/publication/pp729G.]

Christiansen, R.L., and Blank, H.R., Jr., 1972, Volcanic stratigraphy of the Quaternary rhyolite plateau in Yellowstone National Park: U.S. Geological Survey Professional Paper 729-B, 18 p. [Also available at https:// pubs.er.usgs.gov/publication/pp729B.]

Christiansen, R.L., Foulger, G.R., and Evans, J.R., 2002, Upper-mantle origin of the Yellowstone hotspot: Geological Society of America Bulletin, v. 114, no. 10, p. 1,2451,256. [Also available at http://gsabulletin.gsapubs.org/ content/114/10/1245.]
Christiansen, R.L., Lowenstern, J.B., Smith, R.B., Heasler, H., Morgan, L.A., Nathenson, M., Mastin, L.G., Muffler, L.J.P., and Robinson, J.E., 2007, Preliminary assessment of volcanic and hydrothermal hazards in Yellowstone National Park and vicinity: U.S. Geological Survey Open-File Report 2007-1071, 94 p. [Also available at https://pubs.usgs.gov/of/2007/1071/.]

Clifton, C.G., Walters, C.C. and Simoneit, B.R.T., 1990, Hydrothermal petroleums from Yellowstone National Park, Wyoming, U.S.A.: Applied Geochemistry, v. 5, nos. 1-2, p. 169-191. [Also available at http://dx.doi.org/10.1016/08832927(90)90047-9.]

Clor, L.E., Lowenstern, J.B., and Heasler, H.P., 2007, Systematics of water temperature and flow at Tantalus Creek during calendar year 2005, Norris Geyser Basin, Yellowstone National Park, Wyoming: U.S. Geological Survey Scientific Investigations Report 2007-5234, 17 p., accessed at http://pubs.usgs.gov/ sir/2007/5234/.

Coble, M.A., and Mahood, G.A., 2012, Initial impingement of the Yellowstone plume located by widespread silicic volcanism contemporaneous with Colombia River flood basalts: Geology, v. 40, no. 7, p. 655-658. [Also available at https://doi. org $/ 10.1130 / \mathrm{G} 32692.1$.

Coble, M.A., and Mahood, G.A., 2016, Geology of the High Rock caldera complex, northwest Nevada, and implications for intense rhyolitic volcanism associated with flood basalt magmatism and the initiation of the Snake River PlainYellowstone trend: Geosphere, v. 12, no. 1, p. 58-113, accessed at https://doi.org/10.1130/GES01162.1.

Craig, H., Lupton, J.E., Welhan, J.A., and Poreda, R., 1978, Helium isotope ratios in Yellowstone and Lassen Park volcanic gases: Geophysical Research Letters, v. 5, no. 11, p. 897-900. [Also available at https://doi.org/10.1029/GL005i011p00897.]

Dawson, P.B., Benitez, M.C., Lowenstern, J.B., and Chouet, B.A., 2012, Identifying bubble collapse in a hydrothermal system using hidden Markov models: Geophysical Research Letters, v. 39 , no. 1,5 p.

De Filippis, L., and Billi, A., 2012, Morphotectonics of fissure ridge travertines from geothermal areas of Mammoth Hot Springs (Wyoming) and Bridgeport (California): Tectonophysics, v. 548-549, p. $34-48$. [Also available at http:// dx.doi.org/10.1016/j.tecto.2012.04.017.]

Doe, B., Leeman, W., Christiansen, R., and Hedge, C., 1982, Lead and strontium isotopes and related trace elements as genetic tracers in the upper Cenozoic rhyolite-basalt association of the Yellowstone Plateau Volcanic Field: Journal of Geophysical Research Solid Earth, v. 87, no. B6, p. 4,785-4,806. [Also available at http://dx.doi.org/10.1029/ JB087iB06p04785.] 
Doser, D.I., 1985, Source parameters and faulting processes of the 1959 Hebgen Lake, Montana, earthquake sequence: Journal of Geophysical Research Solid Earth, v. 90, no. B6, p. 4,537-4,556. [Also available at http://dx.doi.org/10.1029/ JB090iB06p04537.]

Draper, D.S., 1991, Late Cenozoic bimodal magmatism in the northern Basin and Range province of southeastern Oregon: Journal of Volcanology and Geothermal Research, v. 47, nos. 3-4, p. 299-328. [Also available at http://dx.doi. org/10.1016/0377-0273(91)90006-L.]

Dzurisin, D., Savage, J.C., and Fournier, R.O., 1990, Recent crustal subsidence at Yellowstone Caldera, Wyoming: Bulletin of Volcanology, v. 52, no. 4, p. 247-270. [Also available at http://dx.doi.org/10.1007/BF00304098.]

Dzurisin, D., Wicks, C.W., and Poland, M.P., 2012, History of surface displacements at the Yellowstone Caldera, Wyoming, from leveling surveys and InSAR observations, 1923-2008: U.S. Geological Survey Professional Paper 1788, v. 1.1, 68 p. and data files, accessed at http://pubs.usgs.gov/pp/1788/.

Eaton, G.P., Christiansen, R.L., Iyer, H.M., Pitt, A.M., Blank, H.R., Jr., Zietz, I., Mabey, D.R., and Gettings, M.E., 1975, Magma beneath Yellowstone National Park: Science, v. 188, no. 4190, p. 787-796. [Also available at http://dx.doi.org/10.1126/ science.188.4190.787.]

Ellis, B.S., Mark, D.F., Pritchard, C.J., and Wolff, J.A., 2012, Temporal dissection of the Huckleberry Ridge Tuff using the ${ }^{40} \mathrm{Ar} /{ }^{39} \mathrm{Ar}$ dating technique: Quaternary Geochronology, v. 9, p. 34-41, accessed at http://dx.doi.org/10.1016/j. quageo.2012.01.006.

Farrell, J., Husen, S., and Smith, R.B., 2009, Earthquake swarm identification and b-value mapping of the Yellowstone volcanictectonic system: Journal of Volcanology and Geothermal Research, v. 188, p. 260-276. [Also available at http://doi. org/10.1016/j.jvolgeores.2009.08.008.]

Farrell, J., Smith, R.B., Husen, S., and Diehl, T., 2014a, Tomography from 26 years of seismicity revealing that the spatial extent of the Yellowstone crustal magma reservoir extends well beyond the Yellowstone Caldera: Geophysical Research Letters, v. 41, no. 9, p. 3,068-3,073, accessed at http:// doi.org/10.1002/2014GL059588.

Farrell, J., Smith, R.B., Shelly, D., Puskas, C.M., and Chang, W.C., 2014b, The $\mathrm{M}_{\mathrm{w}} 4.8$ Norris Geyser Basin earthquake of 30 March, 2014 and its relationship to crustal deformation and seismic activity of the Yellowstone volcanic system [abs.]: Abstract presented at the American Geophysical Union Fall Meeting, San Francisco, Calif., Dec. 15-19, 2014, abstract no. S11E-4400, accessed at http://adsabs.harvard.edu/ abs/2014AGUFM.S11E4400F.
Farrell, J., Smith, R.B., Taira, T., Chang, W.L., and Puskas, C.M., 2010, Dynamics and rapid migration of the energetic 2008-2009 Yellowstone Lake earthquake swarm: Geophysical Research Letters, v. 37, no. 19, 5 p. [Also available at http://doi.org/10.1029/2010GL044605.]

Feeley, T.C., Cosca, M.A., and Lindsay, C.R., 2002, Petrogenesis and implications of calc-alkaine cryptic hybrid magmas from Washburn volcano, Absaroka volcanic province, USA: Journal of Petrology, v. 43, no. 4, p. 663-703, accessed at https://doi.org/10.1093/ petrology/43.4.663.

Fenner, C.N., 1938, Contact relations between rhyolite and basalt on Gardiner River, Yellowstone Park: Bulletin of the Geological Society of America, v. 49, no. 9, p. 1,4411,484. [Also available at https://doi.org/10.1130/GSAB-491441.]

Fenner, C.N., 1944, Rhyolite-basalt complex on Gardiner River, Yellowstone Park, Wyoming - A discussion: Bulletin of the Geological Society of America, v. 55, p. 1,0811,096. [Also available at http://bulletin.geoscienceworld. org/content/abull/55/9/1081.full.pdf.]

Finn, C.A., and Morgan, L.A., 2002, High-resolution aeromagnetic mapping of volcanic terrain, Yellowstone National Park: Journal of Volcanology and Geothermal Research, v. 115, nos. 1-2, p. 207-231. [Also available at https://doi.org/10.1016/S0377-0273(01)00317-1.]

Fouke, B.W., 2011, Hot-spring systems geobiologyAbiotic and biotic influences on travertine formation at Mammoth Hot Springs, Yellowstone National Park, USA: Sedimentology, v. 58, no. 1, p. 170-219.

Fouke, B.W., Farmer, J.D., Des Marais, D.J., Pratt, L., Sturchio, N.C., Burns, P.C., and Discipulo, M.K., 2000, Depositional facies and aqueous-solid geochemistry of travertine- depositing hot springs (Angel Terrace, Mammoth Hot Springs, Yellowstone National Park, U.S.A.): Journal of Sedimentary Research, v. 70, no. 3, p. 565-585. [Also available at https://doi. org/10.1306/2DC40959-0E47-11D7-8643000102C1865D.]

Foulger, G.R., Christiansen, R.L., and Anderson, D.L., 2015, The Yellowstone "hot spot" track results from migrating basin-range extension: Geological Society of America Special Paper 514, p. 215-238, accessed at https://doi. org/10.1130/2015.2514(14).

Fournier, R.O., 1989, Geochemistry and dynamics of the Yellowstone National Park hydrothermal system: Annual Review of Earth and Planetary Sciences, v. 17, p. 13-53. [Also available at http://www.annualreviews.org/doi/ abs/10.1146/annurev.ea.17.050189.000305.] 
Fournier, R.O., Christiansen, R.L., Hutchinson, R.A. and Pierce, K.L., 1994, A field-trip guide to Yellowstone National Park, Wyoming, Montana, and Idaho-Volcanic, hydrothermal, and glacial activity in the region: U.S. Geological Survey Bulletin 2099, 46 p. [Also available at http://pubs.er.usgs.gov/publication/b2099.]

Fournier, R.O., Kennedy, B., Mack, A.M., and Thompson, J.M., 1994, Correlation of gold in siliceous sinters with ${ }^{3} \mathrm{He} /{ }^{4} \mathrm{He}$ in hot spring waters of Yellowstone National Park: Geochimica et Cosmochimica Acta, v. 58, no. 24, p. 5,401-5,419. [Also available at http://www.sciencedirect. com/science/article/pii/0016703794902380.]

Fournier, R.O., Thompson, J.M., Cunningham, C.G., and Hutchinson, R.A., 1991, Conditions leading to a recent small hydrothermal explosion at Yellowstone National Park: Geological Society of America Bulletin, v. 103, no. 8, p. 1,114-1,120. [Also available at http://gsabulletin. gsapubs.org/content/103/8/1114.full.pdf+html.]

Fournier, R.O., and Truesdell, A.H., 1973, An empirical Na-K-Ca geothermometer for natural waters: Geochimica et Cosmochimica Acta, v. 37, no. 5, p. 1,255-1,275. [Also available at https://doi.org/10.1130/B25896.1.]

Fournier, R.O., and Truesdell, A.H., 1974, Geochemical indicators of subsurface temperature-Part 2, Estimation of temperature and fraction of hot water mixed with cold water: Journal of Research of the U.S. Geological Survey, v. 2, no. 3, p. 263-270.

Fournier, R.O., Weltman, U., Counce, D., White, L.D., and Janik, C.J., 2002, Results of weekly chemical and isotopic monitoring of selected springs in Norris Geyser Basin, Yellowstone National Park during June-September, 1995: U.S. Geological Survey Open-File Report 02-344, 50 p. [Also available at https://pubs.er.usgs.gov/publication/ ofr02344.]

Fournier, R.O., White, D.E., and Truesdell, A.H., 1976, Convective heat flow in Yellowstone National Park, in Proceedings of the Second United Nations Symposium on the Development and Use of Geothermal Resources: San Francisco, Calif., U.S. Government Printing Office, Washington D.C., v. 1, p. 731-739.

Friedman, Irving, and Norton, D.R., 1990, Anomalous chloride flux discharges from Yellowstone National Park: Journal of Volcanology and Geothermal Research, v. 42, p. 225-234.

Friedman, Irving, and Norton, D.R., 2000, Data used for calculating chloride flux out of Yellowstone National Park for the water years 1983-1999: U.S. Geological Survey Open-File Report 00-194, 48 p. [Also available at https:// pubs.er.usgs.gov/publication/ofr00194.]
Friedman, Irving, and Norton, D.R., 2007, Is Yellowstone losing its steam? - Chloride flux out of Yellowstone National Park, chap. I of Morgan, L.A., ed., Integrated geoscience studies in the greater Yellowstone area-Volcanic, hydrothermal and tectonic processes in the Yellowstone geoecosystem: U.S. Geological Survey Professional Paper 1717, p. 271-297. [Also available at https://pubs.usgs.gov/pp/1717/.]

Gansecki, C.A., Mahood, G.A., and McWilliams, M.O., 1996, ${ }^{40} \mathrm{Ar} /{ }^{39} \mathrm{Ar}$ geochronology of rhyolites erupted following collapse of the Yellowstone Caldera, Yellowstone Plateau Volcanic Field - Implications for crustal contamination: Earth and Planetary Science Letters, v. 142, nos. 1-2, p. 91-108. [Also available at https://doi.org/10.1016/0012821X(96)00088-X.]

Gemery-Hill, P.A., Shanks, W.C.P., III, Balistrieri, L.S., Lee, G.K., 2007, Geochemical data for selected rivers, lake waters, hydrothermal vents and subaerial geysers in Yellowstone National Park, Wyoming, and vicinity, 1996-2002, chap. L of Morgan, L.A., ed., Integrated geoscience studies in the greater Yellowstone area-Volcanic, hydrothermal and tectonic processes in the Yellowstone geoecosystem: U.S. Geological Survey Professional Paper 1717, p. 365-426. [Also available at https://pubs.usgs.gov/pp/1717/.]

Girard, G., and Stix, J., 2009, Magma recharge and crystal mush rejuvenation associated with early post-collapse Upper Basin Member rhyolites, Yellowstone Caldera, Wyoming: Journal of Petrology, v. 50, no. 11, p. 2,095-2,125, accessed at https:// doi.org/10.1093/petrology/egp070.

Girard, G., and Stix, J., 2010, Rapid extraction of discrete magma batches from a large differentiating magma chamber-The Central Plateau Member rhyolites, Yellowstone Caldera, Wyoming: Contributions to Mineralogy and Petrology, v. 160, no. 3, p. 441-465, accessed at https:// doi.org/10.1007/s00410-009-0487-1.

Girard, G., and Stix, J., 2012, Future volcanism at Yellowstone Caldera-Insights from geochemistry of young volcanic units and monitoring of volcanic unret: GSA Today, v. 22, no. 9, p. 4-10, accessed at https://doi.org/10.1130/ GSATG143A.1.

Good, J.M., and Pierce, K.L., 1996, Interpreting the landscape - Recent and ongoing geology of Grand Teton and Yellowstone National Parks: Moose, Wyo., Grand Teton Natural History Society, 58 p.

Graham, D.W., Reid, M.R., Jordan, B.T., Grunder, A.L., Leeman, W.P., and Lupton, J.E., 2009, Mantle source provinces beneath the northwestern USA delimited by helium isotopes in young basalts: Journal of Volcanology and Geothermal Research, v. 188, nos. 1-3, p. 128-140. [Also available at https://doi.org/10.1016/j.jvolgeores.2008.12.004.] 
Guidry, S.A., and Chafetz, H.S., 2002, Factors governing subaqueous siliceous sinter precipitation in hot springsExamples from Yellowstone National Park, USA: Sedimentology, v. 49, no. 6, p. 1,253-1,267. [Also available at https://doi.org/10.1046/j.1365-3091.2002.00494.x.]

Hague, A., 1896, The age of the igneous rocks of the Yellowstone National Park: American Journal of Science, v. 1, no. 6, p. 445457. [Also available at https://doi.org/10.2475/ajs.s4-1.6.445.]

Hamamura, N., Meneghin, J., and Reysenbach, A.L., 2013, Comparative community gene expression analysis of Aquificales-dominated geothermal springs: Environmental Microbiology, v. 15, no. 4, p. 1,226-1,237, accessed at https:// doi.org/10.1111/1462-2920.12061.

Hamilton, W.B., 2003, An alternative Earth: GSA Today, v. 13, no. 11, p. 4-12, accessed at https://www.geosociety.org/ gsatoday/archive/13/.

Hayden, F.V., 1872, Preliminary report of the United States Geological Survey of Montana and portions of adjacent territories - Being a fifth annual report of progress: Washington, D.C., Government Printing Office, 537 p. [Also available at https://archive.org/details/preliminaryrepor00geol.]

Hildreth, W., Christiansen, R.L., and O'Neil, J.R., 1984, Catastrophic isotopic modification of rhyolitic magma at times of caldera subsidence, Yellowstone Plateau Volcanic Field: Journal of Geophysical Research Solid Earth, v. 89, no. B10, p. 8,339-8,369. [Also available at https://doi.org/10.1029/ JB089iB10p08339.]

Hildreth, W., Halliday, A.N., and Christiansen, R.L., 1991, Isotopic and chemical evidence concerning the genesis and contamination of basaltic and rhyolitic magma beneath the Yellowstone Plateau Volcanic Field: Journal of Petrology, v. 32, no. 1, p. 63-138. [Also available at https://doi. org/10.1093/petrology/32.1.63.]

Honjo, N., Bonnichsen, B., Leeman, W.P., and Stormer, J.C., 1992, High-temperature rhyolites from the central and western Snake River Plain: Bulletin of Volcanology, v. 54, p. 220-237. [Also available at http://www.academia.edu/17136180/Hightemperature_rhyolites_from_the_central_and_western_Snake River_Plain.]

Houseal, A.K., Fouke, B.W., Sanford, R., Fuhrmann, R., and Petrick, E., 2010, Mammoth Hot Springs-Where change is constant: Yellowstone Science, v. 18, no. 3, p. 7-14. [Also available at https://www.nps.gov/yell/learn/upload/YS_18_3 sm.pdf.]

Huang, H.H., Lin, F.C., Schmandt, B., Farrell, J., Smith, R.B., and Tsai, V., 2015, The Yellowstone magmatic system from the mantle plume to the upper crust: Science, v. 348, no. 6236, p. 773-776. [Also available at https://doi.org/10.1126/science. aaa5648.]
Hughes, S.S., and McCurry, M., 2002, Bulk major and trace element evidence for a time-space evolution of Snake River Plain rhyolites, Idaho, in Bonnichsen, B., White, C.M., and McCurry, M., eds., Tectonic and magmatic evolution of the Snake River Plain volcanic province: Idaho Geological Survey Bulletin, v. 30, p. 161-176. [Also available at http:/ www.idahogeology.org/PDF/Bulletins_(B)/ Snake_River_Plain_B-30.pdf.]

Humphreys, E.D., Dueker, K.G., Schutt, D.L., and Smith, R.B., 2000, Beneath Yellowstone-Evaluating plume and nonplume models using teleseismic images of the upper mantle: GSA Today, v. 10, no. 12, p. 1-7. [Also available at https://www. geosociety.org/gsatoday/archive/10/12/pdf/i1052-5173-10-12-1. pdf.]

Hurwitz, S., Clor, L.E., McCleskey, B.R., Nordstrom, D.K., Hunt, A.G., and Evans, W.C., 2016, Dissolved gases in hydrothermal (phreatic) and geyser eruptions at Yellowstone National Park, USA: Geology, v. 44, no. 3, p. 235-238. [Also available at https://doi.org/10.1130/G37478.1.]

Hurwitz, S., Hunt, A.G., and Evans, W.C., 2012, Temporal variations of geyser water chemistry in the Upper Geyser basin, Yellowstone National Park, USA: Geochemistry, Geophysics, Geosystems, v. 13, no. 12, 19 p. [Also available at https://doi. org $/ 10.1029 / 2012$ GC004388.]

Hurwitz, S., and Lowenstern, J.B., 2014, Dynamics of the Yellowstone hydrothermal system: Reviews in Geophysics, v. 52, no. 3, p. 375-411. [Also available at http://dx.doi. org/10.1002/2014RG000452.]

Hurwitz, S., Lowenstern, J.B., and Heasler, H., 2007, Spatial and temporal geochemical trends in the hydrothermal system of Yellowstone National Park-Inferences from river solute fluxes: Journal of Volcanology and Geothermal Research, v. 162 , nos. 3-4, p. 149-171. [Also available at http://dx.doi. org/10.1016/j.jvolgeores.2007.01.003.]

Husen, S., Smith, R.B., and Waite, G.P., 2004, Evidence for gas and magmatic sources beneath the Yellowstone Volcanic Field from seismic tomographic imaging: Journal of Volcanology and Geothermal Research, v. 131, nos. 3-4, p. 397-410. [Also available at https://doi.org/10.1016/S0377-0273(03)00416-5.]

Husen, S., Taylor, R., Smith, R.B., and Heasler, H., 2004, Changes in geyser behavior and remotely triggered seismicity in Yellowstone National Park produced by the 2002 M7.9 Denali fault earthquake: Geology, v. 32, no. 6, p. 537-540. [Also available at http://geology.gsapubs.org/ content $/ 32 / 6 / 537$.]

Hutchinson, R.A., Westphal, J.A., and Kieffer, S.W., 1997, In situ observations of Old Faithful geyser: Geology, v. 25, no. 10, p. 875-878. [Also available at http://geology.gsapubs.org/ content/25/10/875.full.pdf + html.] 
Inskeep, W.P., Rusch, D.B., Jay, Z.J., Herrgard, M.J., Kozubal, M.A., Richardson, T.H., Macur, R.E., Hamamura, N., Jennings, R.M., Fouke, B.W., Reysenbach, A.L., Roberto, F., Young, M., Schwartz, A., Boyd, E.S., Badger, J.H., Mathur, E.J., Ortmann, A.C., Bateson, M., Geesey, G., and Frazier, M., 2010, Metagenomes from high-temperature chemotrophic systems reveal geochemical controls on microbial community structure and function: PLOS ONE, v. 5, no. 3., 15 p., accessed at http://dx.doi.org/10.1371/ journal.pone.0009773.

Izett, G.A., 1981, Volcanic ash beds-Records of upper Cenozoic silicic pyroclastic volcanism in the western United States: Journal of Geophysical Research Solid Earth, v. 86 , no. B11, p. 10,200-10,222. [Also available at https:// doi.org/10.1029/JB086iB11p10200.]

Jaggar, T.A., 1922, A plea for geophysical and geochemical observatories: Journal of the Washington Academy of Sciences, v. 12 , no. 15 , p. 343-353.

James, D.E., Fouch, M.J., Carlson, R.W., and Roth, J.B., 2011, Slab fragmentation, edge flow and the origin of the Yellowstone hotspot track: Earth and Planetary Science Letters, v. 311, nos. 1-2, p. 124-135, accessed at http:// dx.doi.org/10.1016/j.epsl.2011.09.007.

Jaworowski, C., Heasler, H.P., Hardy, C.C., and Queen, L.P., 2006, Control of hydrothermal fluids by natural fractures at Norris Geyser Basin: Yellowstone Science, v. 14, no. 4, p. 13-23. [Also available at https://volcanoes.usgs.gov/vsc/ file_mngr/file-25/JaworowskiYellSciFall06.pdf .]

Jaworowski, C., Susong, D., Heasler, H., Mencin, D., Johnson, W., Conrey, R., and Von Stauffenberg, J., 2016, Geologic and geochemical results from boreholes drilled in Yellowstone National Park, Wyoming, 2007 and 2008: U.S. Geological Survey Open-File Report 2016-1028, 39 p. [Also available at http://dx.doi.org/10.3133/ofr20161028.]

Johnson, S.Y., Stephenson, W.J., Morgan, L.A., Shanks, W.C., and Pierce, K.L., 2003, Hydrothermal and tectonic activity in northern Yellowstone Lake, Wyoming: Geological Society of America Bulletin, v. 115, no. 8, p. 954-971. [Also available at http://dx.doi.org/10.1130/B25111.1.]

Kandianis, M., Fouke, B.W., Johnson, R., Veysey, J., and Inskeep, W., 2008, Microbial biomass-A catalyst for $\mathrm{CaCO}_{3}$ precipitation in advection-dominated transport regimes: Bulletin of the Geological Society of America, v. 120 , nos. 3-4, p. 442-450, accessed at http://gsabulletin. gsapubs.org/content/120/3-4/442.

Kedar, S., Sturtevant, B., and Kanamori, H., 1996, The origin of harmonic tremor at Old Faithful geyser: Nature, v. 379, p. 208-711. [Also available at https://doi. org/10.1038/379708a0.]
Kelbert, A., Egbert, G.D., and de Groot-Hein, C., 2012, Crust and upper mantle electrical conductivity beneath the Yellowstone hotspot track: Geology, v. 40, no. 5, p. 447450, accessed at https://doi.org/10.1130/G32655.1.

Kennedy, B.M., Lynch, M.A., Reynolds, J.H., and Smith, S.P., 1985, Intensive sampling of noble gases in fluids at Yellowstone; I-Early overview of the data, regional patterns: Geochimica et Cosmochimica Acta, v. 49, no. 5, p. 1,251-1,261. [Also available at https://doi. org/10.1016/0016-7037(85)90014-6.]

Kharaka, Y.K., Sorey, M.L., and Thordsen, J.J., 2000, Large-scale hydrothermal fluid discharges in the NorrisMammoth corridor, Yellowstone National Park, USA: Journal of Geochemical Exploration, v. 69-70, p. 201205. [Also available at https://doi.org/10.1016/S03756742(00)00025-X.]

Kharaka, Y.K., Thordsen, J.J., and White L.D., 2002, Isotope and chemical compositions of meteoric and thermal waters and snow from the greater Yellowstone National Park region: U.S. Geological Survey Open-File Report 02-194, $75 \mathrm{p}$. [Also available at https://pubs.er.usgs.gov/publication/ ofr02194.]

King, J.S., 1982, Selected volcanic features of the southcentral Snake River Plain, Idaho, in Bonnichsen, B., and Breckenridge, R.M., eds., Cenozoic geology of Idaho: Idaho Bureau of Mines and Geology Bulletin 26, p. 439-454. [Also available at http://geology.isu.edu/Digital_Geology_ Idaho/papers/B-26ch7-3.pdf.]

Kistler, R.W., and Lee, D.E., 1989, Rubidium and strontium isotopic data for a suite of granitoid rocks from the Basin and Range province, Arizona, California, Nevada, and Utah: U.S. Geological Survey Open-File Report 89-199, 13 p. [Also available at https://pubs.er.usgs.gov/publication/ ofr89199.]

Kistler, R.W., Ghent, E.D., and O’Neil, J.R., 1981, Petrogenesis of garnet two-mica granites in the Ruby Mountains, Nevada: Journal of Geophysical Research, v. 86, no. B11, p. 10,591-10,606. [Also available at https:// doi.org/10.1029/JB086iB11p10591.]

Ladd, B.S., and Ryan, C.M., 2016, Can $\mathrm{CO}_{2}$ trigger a thermal geyser eruption?: Geology, v. 44, no. 4, p. 307-310. [Also available at https://doi.org/10.1130/G37588.1.]

Lanphere, M.A., Champion, D.E., Christiansen, R.L., Izett, G.A., and Obradovich, J.D., 2002, Revised ages for tuffs of the Yellowstone Plateau Volcanic Field-Assignment of the Huckleberry Ridge Tuff to a new geomagnetic polarity event: Geological Society of America Bulletin, v. 114, no. 5, p. 559-568. 
Larson, P., Phillips, A., John, D.C., Cosca, M., Pritchard, C., Andersen, A., and Manion, J., 2009, A preliminary study of older hydrothermal alteration in Sevenmile Hole, Grand Canyon of the Yellowstone River, Yellowstone Caldera, Wyoming: Journal of Volcanology and Geothermal Research, v. 188, nos. 1-3, p. 225-236, accessed at https://doi.org/10.1016/j. jvolgeores.2009.07.017.

Leeman, W.P., Annen, C., and Dufek, J., 2008, Snake River Plain-Yellowstone silicic volcanism-Implications for magma genesis and magma fluxes: Geological Society of London Special Publication, v. 304, no. 1, p. 235-259. [Also available at https://doi.org/10.1144/SP304.12.]

Leeman, W.P., Oldow, J.S., and Hart, W.K., 1992, Lithospherescale thrusting in the western U.S. Cordillera as constrained by $\mathrm{Sr}$ and $\mathrm{Nd}$ isotopic transitions in Neogene volcanic rocks: Geology, v. 20, no. 1, p. 63-66.

Leeman, W.P., Schutt, D.L., and Hughes, S.S., 2009, Thermal structure beneath the Snake River Plain - Implications for the Yellowstone hot spot: Journal of Volcanology and Geothermal Research, v. 188, nos. 1-3, p. 57-67. [Also available at http:// dx.doi.org/10.1016/j.jvolgeores.2009.01.034.]

Lehman, J.A., Smith, R.B., and Schilly, M.M., 1982, Upper crustal structure of the Yellowstone Caldera from seismic delay time analyses and gravity correlations: Journal of Geophysical Research Solid Earth, v. 87, no. B4, p. 2,713-2,730. [Also available at https://doi.org/10.1029/ JB087iB04p02713.]

Licciardi, J.M., and Pierce, K.L., 2008, Cosmogenic exposure-age chronologies of Pinedale and Bull Lake glaciations in greater Yellowstone and the Teton Range, USA: Quaternary Science Reviews, v. 27, nos. 7-8, p. 814-831. [Also available at https:// doi.org/10.1016/j.quascirev.2007.12.005.]

Lin, P., Deering, C.D., Werner, C.A., and Torres, C., 2015, Origin and quantification of $\mathrm{CO}_{2}$ and $\mathrm{H}_{2} \mathrm{~S}$ emission at Crater Hills, Yellowstone National Park [abs.]: Abstract presented at the American Geophysical Union Fall Meeting, San Francisco, Calif., Dec. 14-18, 2016, abstract no. V23B-3094, accessed at http://adsabs.harvard.edu/abs/2015AGUFM. V23B3094L.

Link, P.K., McDonald, H.G., Fanning, C.M., and Godfrey, A.E., 2002, Detrital zircon evidence for Pleistocene drainage reversal at Hagerman Fossil Beds National Monument, Central Snake River Plain, Idaho, in Bonnichsen, B., White, C.M., and McCurry, M., eds., Tectonic and magmatic evolution of the Snake River Plain volcanic province: Idaho Geological Survey Bulletin 30, p. 105-119. [Also available at http://www.idahogeology.org/PDF/Bulletins_(B)/Snake_ River_Plain_B-30.pdf.]
Livo, K.E., Kruse, F.A., Clark, R.N., Kokaly, R.F., and Shanks, W.C., III, 2007, Hydrothermally altered rock and hot-spring deposits at Yellowstone National Park - Characterized using airborne visible- and infrared-spectroscopy data, chap. O of Morgan, L.A., ed., Integrated geoscience studies in the greater Yellowstone area-Volcanic, hydrothermal and tectonic processes in the Yellowstone geoecosystem: U.S. Geological Survey Professional Paper 1717, p. 491-507. [Also available at https://pubs.usgs.gov/pp/1717/.]

Locke, W.W., and Meyer, G., 1994, A 12,000-year record of vertical deformation across the Yellowstone Caldera margin - The shorelines of Yellowstone Lake: Journal of Geophysical Research Solid Earth, v. 99, no. B10, p. 20,07920,094. [Also available at http://onlinelibrary.wiley.com/ doi/10.1029/94JB00243/epdf.]

Locke, W.W., Meyer, G.A., and Pings, J.C., 1992, Morphology of a post-glacial fault scarp across the Yellowstone (Wyoming) caldera margin, and its implications: Seismological Society of America Bulletin, v. 82, no. 1, p. 511-516. [Also available at http://www.bssaonline.org/content/82/1/511.extract.]

Loewen, M.W., and Bindeman, I.N., 2015, Oxygen isotope and trace element evidence for three-stage petrogenesis of the youngest episode (260-79 ka) of Yellowstone rhyolitic volcanism: Contributions to Mineralogy and Petrology, v. 170 , no. 39,25 p., accessed at https://doi.org/10.1007/ s00410-015-1189-5.

Loewen, M.W., and Bindeman, I.N., 2016, Oxygen isotope thermometry reveals high temperature magmatic temperatures and short residence times in Yellowstone and other hotdry rhyolites compared to cold-wet systems: American Mineralogist, v. 101, no. 5, p. 1,222-1,227, accessed at https:// doi.org/10.2138/am-2016-5591.

Love, J.D., and Good, J.M., 1970, Hydrocarbons in thermal areas, northwestern Wyoming: U.S. Geological Survey Professional Paper 644-B, 23 p. [Also available at https://pubs.er.usgs.gov/ publication/pp644B.]

Love, J.D., Good, J.M., and Browne, D.G., 2007, Reconnaissance study of Pleistocene lake and fluvial deposits in and near ancestral Yellowstone Lake, Wyoming, chap. C of Morgan, L.A., ed., Integrated geoscience studies in the greater Yellowstone area-Volcanic, hydrothermal and tectonic processes in the Yellowstone geoecosystem: U.S. Geological Survey Professional Paper 1717, p. 53-90. [Also available at https://pubs.usgs.gov/pp/1717/.]

Lowenstern, J.B., Bergfeld, D., Evans, W.C., and Hunt, A.G., 2015, Origin of geothermal gases at Yellowstone: Journal of Volcanology and Geothermal Research, v. 302, p. 87-101. [Also available at https://doi.org/10.1016/j. jvolgeores.2015.06.010.] 
Lowenstern, J.B., Bergfeld, D., Evans, W.C., and Hurwitz, S., 2012, Generation and evolution of hydrothermal fluids at Yellowstone - Insights from the Heart Lake Geyser basin: Geochemistry Geophysics Geosystems, v. 13, no. 1, 11 p., accessed at https://doi.org/10.1029/2011GC003835.

Lowenstern, J.B., Christiansen, R.L, Smith, R.B., Morgan, L.A., and Heasler, H., 2005, Steam explosions, earthquakes, and volcanic eruptions-What's in Yellowstone's future?: U.S. Geological Survey Fact Sheet 2005-3024, 6 p. [Also available at https://pubs.er.usgs.gov/publication/fs20053024.]

Lowenstern, J.B., Evans, W.C., and Bergfeld, D., 2005, Diffuse and direct sources of $\mathrm{CO}_{2}$ from Terrace Springs, a large-discharge travertine-forming spring at Yellowstone National Park: Presented at the 9th Workshop of the IAVCEI Commission on the Chemistry of Volcanic Gases, Palermo, Italy, May 1-10, 2005, Palermo, Italy, International Association for Volcanology and Chemistry of the Earth's Interior [IAVCEI], accessed at https://doi.org/10.13140/ RG.2.1.1675.3681.

Lowenstern, J.B., Evans, W.C., Bergfeld, D., and Hunt, A.G., 2014, Prodigious degassing of a billion years of accumulated radiogenic helium at Yellowstone: Nature, v. 506, no. 7488, p. 355-358, accessed at https://doi.org/10.1038/nature12992.

Lowenstern, J.B., Heasler, H., and Smith, R.B., 2003, Hydrothermal disturbances at the Norris Geyser Basin, Yellowstone National Park (USA) in 2003 [abs.]: Abstracts of Eos, Transactions American Geophysical Union 2003 Fall Meeting, San Francisco, Calif., Dec. 8-12, 2003, supplemental abstract no. V31B-05. [Also available at http://abstractsearch. agu.org/meetings/2003/FM/V31B-05.html.]

Lowenstern, J.B., and Hurwitz, S., 2008, Monitoring a supervolcano in repose- Heat and volatile flux at the Yellowstone Caldera: Elements, v. 4, p. 35-40. [Also available at https://doi.org/10.2113/GSELEMENTS.4.1.35.]

Lowry, A.R., Ribe, N.M., and Smith, R.B., 2000, Dynamic elevation of the Cordillera, western United States: Journal of Geophysical Research, v. 105, no. B10, p. 23,371-23,390, accessed at https://doi.org/10.1029/2000JB900182.

Luttrell, K., Mencin, D., Francis, O., and Hurwitz, S., 2013, Constraints on the upper crustal magma reservoir beneath Yellowstone Caldera inferred from lake-seiche induced strain observations: Geophysical Research Letters, v. 40, no. 3, p. 501506. [Also available at https://doi.org/10.1002/grl.50155.]

Manea, V.C., Manea, M., Leeman, W.P., and Schutt, D.L., 2009, The influence of plume head-lithosphere interaction on magmatism associated with the Yellowstone hotspot track: Journal of Volcanology and Geothermal Research, v. 188, nos. 1-3, p. 68-85. [Also available at https://doi.org/10.1016/j. jvolgeores.2008.12.012.]
Manion, J.L., 2010, Epithermal alteration in tuff of Sulphur Creek, Yellowstone National Park, Wyoming: Pullman, Wash., Washington State University, M.S. thesis, 472 p. [Also available at http://www.dissertations.wsu.edu/Thesis/ Summer2010/j_manion_050710.pdf.]

Mansfield, G.R., and Ross, C.S., 1935, Welded rhyolitic tuffs in southeastern Idaho: Eos, Transactions, American Geophysical Union, v. 16, no. 1, p. 308-321. [Also available at http://onlinelibrary.wiley.com/doi/10.1029/ TR016i001p00308/full.]

Marler, G.D., and White, D.E., 1975, Seismic geyser and its bearing on the origin and evolution of geysers and hot springs of Yellowstone National Park: Geological Society of America Bulletin, v. 86, no. 6, p. 749-759. [Also available at https://doi.org/10.1130/0016-7606(1975)86<749:SGAIBO> 2.0.CO;2.]

Massin, F., Farrell, J., and Smith, R.B., 2013, Repeating earthquakes in the Yellowstone Volcanic Field-Implications for rupture dynamics, ground deformation, and migration in earthquake swarms: Journal of Volcanology and Geothermal Research, v. 257, p. 159-173, accessed at https://doi. org/10.1016/j.jvolgeores.2013.03.022.

Mastin, L.G., 1995, Thermodynamics of gas and steam-blast eruptions: Bulletin of Volcanology, v. 57, no. 2, p. 85-98. [Also available at https://doi.org/10.1007/BF00301399.]

Mastin, L.G., Van Eaton, A.R., and Lowenstern, J.B., 2014, Modeling ash fall distribution from a Yellowstone supereruption: Geochemistry, Geophysics, Geosystems, v. 15 , no. 8 , p. $3,459-3,475$, accessed at https://doi. org/10.1002/2014GC005469.

Matthews, N.E., Vazquez, J.A., and Calvert, A.T., 2015, Age of the Lava Creek supereruption and magma chamber assembly at Yellowstone based on ${ }^{40} \mathrm{Ar} /{ }^{39} \mathrm{Ar}$ and $\mathrm{U}-\mathrm{Pb}$ dating of sanidine and zircon crystals: Geochemistry, Geophysics, Geosystems, v. 16 , no. 8 , p. 2,508-2,528, accessed at https:// doi.org/10.1002/2015GC005881.

McCleskey, R.B., Ball, J.W., Nordstrom, D.K., Holloway, J.M., and Taylor, H.E., 2004, Water-chemistry data for selected hot springs, geysers and streams in Yellowstone National Park, Wyoming, 2001-2002: U.S. Geological Survey OpenFile Report 2004-1316, accessed at http://pubs.usgs.gov/ of/2004/1316/.

McCleskey, R.B., Chiu, R.B., Nordstrom, D.K., Campbell, K.M., Roth, D.A., Ball, J.W., and Plowman, T.I., 2014, Water chemistry data for selected springs, geysers, and streams in Yellowstone National Park, Wyoming, beginning 2009-Sample information [Supporting files, sample information pdf]: U.S. Geological Survey web page, accessed at https://doi.org/10.5066/F7M043FS. 
McCleskey, R.B., Nordstrom, D.K., Susong, D.D., Ball, J.W., and Taylor, H.E., 2010, Source and fate of inorganic solutes in the Gibbon River, Yellowstone National Park, Wyoming, USA; II-Trace element chemistry: Journal of Volcanology and Geothermal Research, v. 196, nos. 3-4, p. 139-155, accessed at http://dx.doi.org/10.1016/j. jvolgeores.2010.05.004.

McCurry, M., and Rodgers, D.W., 2009, Mass transfer along the Yellowstone hot spot track I-Petrologic constraints on the volume of mantle-derived magma: Journal of Volcanology and Geothermal Research, v. 188, nos. 1-3, p. 86-98. [Also available at http://dx.doi.org/10.1016/j. jvolgeores.2009.04.001.]

McKibben, R., 1990, Mathematical modeling of hydrothermal eruptions: Geothermal Resources Council Transactions, v. 14, pt. 2, p. 1,309-1,316. [Also available at https://www. geothermal-library.org/index.php? mode=pubs\&action=view \&record=1002040.]

Meertens, C.M., and Smith, R.B., 1991, Crustal deformation of the Yellowstone Caldera from first GPS measurements; 1987-1989: Geophysical Research Letters, v. 18, no. 9, p. 1,763-1,766. [Also available at http://dx.doi. org/10.1029/91GL01470.]

Meqbel, N., Egbert, G.D., Wannamaker, P.E., Kelbert, A., and Schultz, A., 2014, Deep electrical resistivity structure of the northwestern U.S. derived from 3-D inversion of USArray magnetotelluric data: Earth and Planetary Science Letters, v. 402, p. 290-304, accessed at http://dx.doi.org/10.1016/j. eps1.2013.12.026.

Meyer, G.A., and Locke, W.W., 1986, Origin and deformation of Holocene shoreline terraces, Yellowstone Lake, Wyoming: Geology, v. 14, no. 8, p. 699-702. [Also available at http://geology.gsapubs.org/content/14/8/699.]

Miller, D.S., and Smith, R.B., 1999, P and S velocity structure of the Yellowstone Volcanic Field from local earthquake and controlled source tomography: Journal of Geophysical Research Solid Earth, v. 104, no. B7, p. 15,105-15,121. [Also available at http://dx.doi.org/10.1029/1998JB900095.]

Morgan, L.A., and McIntosh, W.C., 2005, Timing and development of the Heise Volcanic Field, Snake River Plain, Idaho, western USA: Bulletin of the Geological Society of America, v. 117, nos. 3-4, p. 288-306. [Also available at http://gsabulletin.gsapubs.org/content/117/3-4/288.]

Morgan, L.A., McIntosh, W.C., and Pierce, K.L., 1997, Inferences for changes in plume dynamics from stratigraphic framework studies of ignimbrites, central Snake River Plain, Idaho: Geological Society of America Abstracts with Programs, v. 29, no. 6, p. 299.
Morgan, L.A., Pierce, K.L., and Shanks, W.C.P., 2008, Track of the Yellowstone hot spot-Young and on-going processes from the Snake River Plain to the Yellowstone Plateau, in Raynolds, R.G., ed., Roaming the Rocky Mountains and environs: Geological Society of America Field Guide 10, p. 139-174. [Also available at http://dx.doi. org/10.1130/2008.fld010(08).]

Morgan, L.A., and Shanks, W.C.P., III, 2005, Influences of rhyolitic lava flows on hydrothermal processes in Yellowstone Lake and on the Yellowstone Plateau, in Inskeep, W.P., and McDermott, T.R., eds., Geothermal biology and geochemistry in Yellowstone National Park: Bozeman, Mont., Thermal Biology Institute, Montana State University, p. 31-52. [Also available at http://www.rcn.montana.edu/Publications/Detail. aspx?id=68.]

Morgan, L.A., Shanks, W.C.P., III, Lee, G.K., and Webring, M.W., 2007a, Bathymetry and geology of the floor of Yellowstone Lake, Yellowstone National Park, Wyoming, Idaho, and Montana: U.S. Geological Survey Scientific Investigations Map 2973, 2 pls. [Also available at https:/pubs.er.usgs.gov/ publication/sim2973.]

Morgan, L.A., Shanks, W.C.P., III, Lovalvo, D.A., Johnson, S.Y., Stephenson, W.J., Pierce, K.L., Harlan, S.S., Finn, C.A., Lee, G., Webring, M., Schulze, B., Duehn, J., Sweeney, R.E., and Balistrieri, L.S., 2003, Exploration and discovery in Yellowstone Lake-Results from high-resolution sonar imaging, seismic reflection profiling, and submersible studies: Journal of Volcanology and Geothermal Research, v. 122, nos. 3-4, p. 221-242. [Also available at http://dx.doi. org/10.1016/S0377-0273(02)00503-6.]

Morgan, L.A., Shanks, W.C.P., III, and Pierce, K.L., 2009, Hydrothermal processes above the Yellowstone magma chamber - Large hydrothermal systems and large hydrothermal explosions: Geological Society of America Special Paper 459, p. 1-95. [Also available at http://dx.doi. org/10.1130/2009.2459(01).]

Morgan, L.A., Shanks, W.C.P., III, Pierce, K.L., Lovalvo, D.A., Lee, G.A., Webring, M.W., Stephenson, W.J., Stephenson, W.J., Harlan, S.S., Schulze, B., and Finn, C.A., 2007b, The floor of Yellowstone Lake is anything but quiet-New discoveries from high-resolution sonar imaging, seismic reflection profiling, and submersible studies, chap. D of Morgan, L.A., ed., Integrated geoscience studies in the greater Yellowstone area-Volcanic, hydrothermal and tectonic processes in the Yellowstone geoecosystem: U.S. Geological Survey Professional Paper 1717, p. 91-126. [Also available at https://pubs.usgs.gov/ $\mathrm{pp} / 1717 /$.

Morgan, W.J., 1972, Plate motions and deep-mantle convection: Geological Society of America Memoir, v. 132, p. 7-22. [Also available at http://dx.doi.org/10.1130/MEM132-p7.] 
Morgavi, D., Arzilli, F., Pritchard, C., Perugini, D., Mancini, L., Larson, P., and Dingwell, D.B., 2016, The Grizzly Lake Complex (Yellowstone Volcano, USA)—Mixing between basalt and rhyolite unraveled by microanalysis and X-ray microtomography: Lithos, v. 260, p. 457-474. [Also available at http://dx.doi.org/10.1016/j.lithos.2016.03.026.]

Muffler, L.J.P., White, D.E., Beeson, M.H., and Truesdell, A.H., 1982, Geologic map of Upper Geyser Basin, Yellowstone National Park, Wyoming: U.S. Geological Survey Miscellaneous Investigations Series Map I-1371, 1 sheet, scale 1:4,800. [Also available at https://pubs.er.usgs.gov/publication/ i1371.]

Muffler, L.J.P., White, D.E., and Truesdell, A.H., 1971, Hydrothermal explosion craters in Yellowstone National Park: Geological Society of America Bulletin, v. 82, no. 3, p. 723-740. [Also available at http://gsabulletin.gsapubs.org/ content $/ 82 / 3 / 723$.]

Myers, M.L., Wallace, P.J., Wilson, C.J.N., Morter, B.K., and Swallow, E.J., 2016, Prolonged ascent and episodic venting of discrete magma batches at the onset of the Huckleberry Ridge supereruption, Yellowstone: Earth and Planetary Science Letters, v. 451, p. 285-297, accessed at http://dx.doi. org/10.1016/j.epsl.2016.07.023.

Nash, B.P., Perkins, M.E., Christensen, J.N., Lee, D.C., and Halliday, A.N., 2006, The Yellowstone hotspot in space and time - $\mathrm{Nd}$ and $\mathrm{Hf}$ isotopes in silicic magmas: Earth and Planetary Science Letters. v. 247, nos. 1-2, p. 143-156. [Also available at http://dx.doi.org/10.1016/j. epsl.2006.04.030.]

Nastanski, N.M., 2005, Petrogenesis of extracaldera rhyolites at Yellowstone Volcanic Field-Evidence for an evolving silicic magma system north of Yellowstone Caldera: Las Vegas, Nev., University of Nevada, Las Vegas, M.S. thesis, $192 \mathrm{p}$.

Nordstrom, D.K., McCleskey, R.B., and Ball, J.W., 2009, Sulfur geochemistry of hydrothermal waters in Yellowstone National Park - IV acid-sulfate waters: Applied Geochemistry, v. 24, no. 2, p. 191-207, accessed at http://dx.doi.org/10.1016/j. apgeochem.2008.11.019.

Norris, P.W., 1881, Fifth Annual Report of the Superintendent of the Yellowstone National Park: Washington, D.C., Government Printing Office, 94 p. [Also available at https://archive.org/ details/annualreportofsu1881unit.]

Obradovich, J.D., 1992, Geochronology of the late Cenozoic volcanism of Yellowstone National Park and adjoining areas, Wyoming and Idaho: U.S. Geological Survey Open File Report 92-408, 45 p. [Also available at https://pubs.er.usgs. gov/publication/ofr92408.]
Obrebski, M., Allen, R.M., Pollitz, F., and Hung, S.H., 2011, Lithosphere-asthenosphere interaction beneath the western United States from the joint inversion of bodywave travel times and surface-wave phase velocities: Geophysical Journal International, v. 185, no. 2, p. 1,003-1,021, accessed at https://doi.org/10.1111/j.1365246X.2011.04990.x.

Old Faithful Science Review Panel, 2014, Hydrogeology of the Old Faithful area, Yellowstone National Park, Wyoming, and its relevance to natural resources and infrastructure: U.S. Geological Survey Open-File Report 2014-1058, 28 p., accessed at http://doi.org/10.3133/ ofr20141058.

Otis, R.M., Smith, R.B., and Wold, R.J., 1977, Geophysical surveys of Yellowstone Lake, Wyoming: Journal of Geophysical Research, v. 82, no. 26, p. 3,705-3,717. [Also available at https://doi.org/10.1029/JB082i026p03705.]

Parsons, T., Thompson, G.A., and Sleep, N.H., 1994, Mantle plume influence on the Neogene uplift and extension of the U.S. western Cordillera?: Geology, v. 23, no. 1, p. 83-86. [Also available at http://geology.gsapubs.org/ content $/ 22 / 1 / 83$.]

Pelton, J.R., and Smith, R.B., 1979, Recent crustal uplift in Yellowstone National Park: Science, v. 206, no. 4423, p. 1,179-1,182. [Also available at https://doi.org/10.1126/ science.206.4423.1179.]

Pelton, J.R., and Smith, R.B., 1982, Contemporary vertical surface displacements in Yellowstone National Park: Journal of Geophysical Research Solid Earth, v. 87, no. B4, p. 2,745-2,761. [Also available at https://doi.org/10.1029/ JB087iB04p02745.]

Perkins, M.E., and Nash, B.P., 2002, Explosive silicic volcanism of the Yellowstone hotspot-The ash fall tuff record: Bulletin of the Geological Society of America, v. 114 , no. 3, p. 367-381. [Also available at http:// gsabulletin.gsapubs.org/content/114/3/367.]

Phillips, A.R., 2010, An oxygen isotope, fluid inclusion, and mineralogy study of the ancient hydrothermal alteration in the Grand Canyon of the Yellowstone River, Yellowstone National Park, Wyoming: Pullman, Wash., Washington State University, M.S. thesis, 142 p., accessed at http://citeseerx. ist.psu.edu/viewdoc/download?doi=10.1.1.428.3039\&rep=r ep1\&type=pdf.

Pierce, K.L., 1979, History and dynamics of glaciation in the northern Yellowstone National Park area: U.S. Geological Survey Professional Paper 729-F, 90 p., 4 pls. [Also available at https://pubs.er.usgs.gov/publication/pp729F.] 
Pierce, K.L., 2004, Pleistocene glaciations of the Rocky Mountains, in Gillespie, A.R., Porter, S.C., and Atwater, B.F., eds., The Quaternary Period in the United States: Developments in Quaternary Science, v. 1, p. 63-76. [Also available at http:// dx.doi.org/10.1016/S1571-0866(03)01004-2.]

Pierce, K.L., Cannon, K.P., Meyer, G.A., Trebesch, M.J., and Watts, R., 2002, Post-glacial inflation-deflation cycles, tilting and faulting in the Yellowstone Caldera based on Yellowstone Lake shorelines: U.S. Geological Survey Open-File Report 02-0142, 61 p. [Also available at https://pubs.er.usgs.gov/ publication/ofr02142.]

Pierce, K.L., Despain, D.G., Morgan, L.A., and Good, J.M., 2007, The Yellowstone hotspot, greater Yellowstone ecosystem, and human geography, chap. A of Morgan, L.A., ed., Integrated geoscience studies in the greater Yellowstone area-Volcanic, hydrothermal and tectonic processes in the Yellowstone geoecosystem: U.S. Geological Survey Professional Paper 1717, p. 1-35. [Also available at https:// pubs.usgs.gov/pp/1717/.]

Pierce, K.L., Licciardi, J.M., Krause, T.R., and Whitlock, C., 2014, Glacial and Quaternary geology of the northern Yellowstone area, Montana and Wyoming, in Shaw, C.A., and Tikoff, B., eds., Exploring the northern Rocky Mountains: Geological Society of America Field Guide 37, p. 189-203. [Also available at https://doi.org/10.1130/2014.0037(09).]

Pierce, K.L., and Morgan, L.A., 1990, The track of the Yellowstone hotspot-Volcanism, faulting, and uplift: U.S. Geological Survey Open-File Report 90-0415, 70 p. [Also available at https://pubs.er.usgs.gov/publication/ofr90415.]

Pierce, K.L., and Morgan, L.A., 1992, The track of the Yellowstone hot spot-Volcanism, faulting, and uplift, in Link, P.K., Kuntz, M.A., and Platt, L.B., eds., Regional geology of eastern Idaho and western Wyoming: Geological Society of America Memoir 179, p. 1-53. [Also available at http://dx.doi. org/10.1130/MEM179.]

Pierce, K.L., and Morgan, L.A., 2009, Is the track of the Yellowstone hotspot driven by a deep mantle plume?Review of volcanism, faulting, and uplift in light of new data: Journal of Volcanology and Geothermal Research, v. 188, nos. 1-3, p. 1-25. [Also available at http://dx.doi. org/10.1016/j.jvolgeores.2009.07.009.]

Pierce, K.L., Morgan, L.A., and Saltus, R.W., 2002, Yellowstone plume head-Postulated tectonic relations to the Vancouver slab, continental boundaries, and climate, in Bonnichsen, B., White, C., and McCurry, M., eds., Tectonic and magmatic evolution of the Snake River Plain volcanic province: Idaho Bureau of Mines and Geology Bulletin 30, p. 5-33. [Also available at http://www.rcn.montana.edu/Publications/ Pdf/2000/Y\%20plumehead_Idaho\%20volume.pdf.]
Pierce, K.L., Obradovich, J.D., and Friedman, I., 1976, Obsidian hydration dating and correlation of Bull Lake and Pinedale Glaciations near West Yellowstone, Montana: Bulletin of the Geological Society of America, v. 87, no. 5, p. 703-710. [Also available at http://gsabulletin.gsapubs. org/content/87/5/703.]

Pitt, A.M., Weaver, C.S., and Spence, W., 1979, The Yellowstone Park earthquake of June 30, 1975: Seismological Society of America Bulletin, v. 69, no. 1, p. 187-205. [Also available at http://bssa.geoscienceworld. org/content/69/1/187.]

Pritchard, C.J., and Larson, P.B., 2012, Genesis of the post-caldera eastern Upper Basin Member rhyolites, Yellowstone, WY - From volcanic stratigraphy, geochemistry, and radiogenic isotope modeling: Contributions to Mineralogy and Petrology, v. 164, no. 2, p. 205-228, accessed at https://doi.org/10.1007/s00410-0120733-9.

Pritchard, C.J., Larson, P.B., Spell, T.L., and Tarbert, K.D., 2013, Eruption-triggered mixing of extra-caldera basalt and rhyolite complexes along the East Gallatin-Washburn Fault Zone, Yellowstone National Park, WY, USA: Lithos, v. 175-176, p. 163-177, accessed at http://dx.doi. org/10.1016/j.lithos.2013.04.022.

Reynolds, R.L., 1977, Paleomagnetism of welded tuffs of the Yellowstone Group: Journal of Geophysical Research Solid Earth: v. 82, p. 3,677-3,693. [Also available at https://doi. org/10.1029/JB082i026p03677.]

Richmond, G.M., 1976, Surficial geologic history of the Canyon Village quadrangle, Yellowstone National Park, Wyoming, for use with map I-652: U.S. Geological Survey Bulletin 1427, 35 p. [Also available at https://pubs.er.usgs. gov/publication/b1427.]

Rye, R.O., and Truesdell, A.H., 2007, The question of recharge to the deep thermal reservoir underlying the geysers and hot springs of Yellowstone National Park, chap. H of Morgan, L.A., ed., Integrated geoscience studies in the greater Yellowstone area-Volcanic, hydrothermal and tectonic processes in the Yellowstone geoecosystem: U.S. Geological Survey Professional Paper 1717, p. 235-270. [Also available at https://pubs.usgs.gov/ $\mathrm{pp} / 1717 /$.

Savov, I.P., Leeman, W.P., Lee, C.T.A., and Shirey, S.B., 2009, Boron isotope variations in NW USA rhyolitesYellowstone, Snake River Plain, eastern Oregon: Journal of Volcanology and Geothermal Research, v. 188, nos. 1-3, p. 162-172. [Also available at https://doi.org/10.1016/j. jvolgeores.2009.03.008.] 
Schilly, M.M., Smith, R.B., Braile, L.W., Ansorge, J., Lehman, J.A., and Braile, L.W., 1982, The 1978 Yellowstone-Eastern Snake River Plain seismic profiling experiment-Data and upper crustal structure of the Yellowstone Region: Journal of Geophysical Research Solid Earth, v. 87, no. B4, p. 2,692-2,704. [Also available at https://doi. org/10.1029/JB087iB04p02692.]

Schreier, C., 1992, A field guide to Yellowstone's geysers, hot springs and fumaroles: Moose, Wyo., Homestead Publishing, $128 \mathrm{p}$.

Shanks, W.C.P., III, Alt, J.C., and Morgan, L.A., 2007, Geochemistry of sublacustrine hydrothermal deposits in Yellowstone Lake - Hydrothermal reactions, stable-isotope systematics, sinter deposition, and spire growth, chap. G of Morgan, L.A., ed., Integrated geoscience studies in the greater Yellowstone area-Volcanic, hydrothermal and tectonic processes in the Yellowstone geoecosystem: U.S. Geological Survey Professional Paper 1717, p. 201-234. [Also available at https://pubs.usgs.gov/pp/1717/.]

Shanks, W.C.P., III, Morgan, L.A., Balistrieri, L., and Alt, J.C., 2005, Hydrothermal vent fluids, siliceous hydrothermal deposits, and hydrothermally altered sediments in Yellowstone Lake, in Inskeep, W.P., and McDermott, T.R., eds., Geothermal biology and geochemistry in Yellowstone National Park: Bozeman, Mont., Thermal Biology Institute, Montana State University, p. 54-72. [Also available at http://www.ren. montana.edu/Publications/Detail.aspx?id=155.]

Shanks, W.C.P., III, and Thurston, R., 2012, Volcanogenic massive sulfide occurrence model: U.S. Geological Survey Scientific Investigations Report 2010-5070-C, 345 p. [Also available at http://pubs.usgs.gov/sir/2010/5070/c/.]

Sheehan, K.B., Patterson, D.J., Dicks, B.L., and Henson, J.M., 2005, Seen and unseen-Discovering the microbes of Yellowstone: Guilford, Conn., Falcon Guides, 106 p.

Shelly, D.R., Hill, D.P., Massin, F., Farrell, J., Smith, R.B., and Taira, T., 2013, A fluid-driven earthquake swarm on the margin of the Yellowstone Caldera: Journal of Geophysical Research Solid Earth, v. 118 , no. 9, p. 4,872-4,886, accessed at https:// doi.org/10.1002/jgrb.50362.

Shock, E.L., Holland, M., Meyer-Dombard, D., Amend, J.P., Osburn, G.R., and Fischer, T.P., 2010, Quantifying inorganic sources of geochemical energy in hydrothermal ecosystems, Yellowstone National Park, USA: Geochimica et Cosmochimica Acta, v. 74, nos. 14-15, p. 4,005-4,043. [Also available at http://dx.doi.org/10.1016/j.gca.2009.08.036.]

Smedes, H.W., and Prostka, H.J., 1972, Stratigraphic framework of the Absaroka Volcanic Supergroup in the Yellowstone National Park region: U.S. Geological Survey Professional Paper 729-C, 32 p. [Also available at https://pubs.er.usgs.gov/ publication/pp729C.]
Smith, E., and Bennett, K., 2006, Panther Creek volcano: Yellowstone Science, v. 14, no. 1, p. 5-12. [Also available at https://www.nps.gov/yell/learn/upload/ys_14_1_sm.pdf.]

Smith, M., Lageson, D., Heatherington, A., and Harlan, S., 1995, Geochronology, geochemistry, and isotopic systematics of the basalt of Hepburn Mesa, Yellowstone River Valley, Montana [abs.]: Geological Society of America Abstracts with Programs, v. 27, no. 4, p. 56.

Smith, R.B., and Arabasz, W.J., 1991, Seismicity of the Intermountain Seismic Belt, in Slemmons, D.B., Engdahl, E.R., Zoback, M.D., and Blackwell, D.D., eds., Neotectonics of North America-To accompany the neotectonic maps, part of the continent-scale maps of North America: Geological Society of America, decade map volume, p. 185-228.

Smith, R.B. and Braile, L.W., 1994, The Yellowstone hotspot: Journal of Volcanology and Geothermal Research, v. 61, nos. 3-4, p. 121-187. [Also available at https://doi. org/10.1016/0377-0273(94)90002-7.]

Smith, R.B., Jordan, M., Steinberger, B., Puskas, C.M., Farrell, J., Waite, G.P., Husen, S., Chang, W.L., and O'Connell, R., 2009, Geodynamics of the Yellowstone hotspot and mantle plume-Seismic and GPS imaging, kinematics, and mantle flow: Journal of Volcanology and Geothermal Research, v. 188, nos. 1-3, p. 26-56. [Also available at https://doi. org/10.1016/j.jvolgeores.2009.08.020.]

Smith, R.B., Schilly, M.M., Braile, L.W., Ansorge, J., Lehman, J.L., Baker, M.R., Prodehl, C., Healy, J.H., Mueller, S., and Greensfelder, R.W., 1982, The 1978 Yellowstone-Eastern Snake River Plain seismic profiling experiment-Crustal structure of the Yellowstone region and experiment design: Journal of Geophysical Research Solid Earth, v. 87, no. B4, p. 2,583-2,596. [Also available at https://doi.org/10.1029/ JB087iB04p02583.]

Smith, R.B., and Siegel, L.J., 2000, Windows into the Earth-The geologic story of Yellowstone and Grand Teton National Parks: New York, Oxford University Press, 242 p.

Smith, T., and McKibben, R., 2000, An investigation of boiling processes in hydrothermal eruptions: Proceedings of the World Geothermal Conference, Kyushu, Japan, May 28-June 10, 2000, Auckland New Zealand, International Geothermal Association, v. 1, p. 699-704. [Also available at https://www.geothermal-energy.org/pdf/IGAstandard/ WGC/2000/R0133.PDF.]

Sorey, M.L., and Colvard, E.M., 1997, Hydrologic investigations in the Mammoth Corridor, Yellowstone National Park and vicinity, U.S.A.: Geothermics, v. 26, no. 2, p. 221-249. [Also available at http://dx.doi. org/10.1016/S0375-6505(96)00041-7.] 
Sorey, M.L., Colvard, E.M., Nimick, D.A., Shields, R.R., and Thordsen, J.J.,1991, Hydrologic investigations in the Corwin Springs known geothermal resources area and adjacent parts of Yellowstone National Park, chap. G of Sorey, M.L., ed., Effects of potential geothermal development in the Corwin Springs known geothermal resources area, Montana, on the thermal features of Yellowstone National Park: U.S. Geological Survey Water-Resources Investigations Report 91-4052, p. G1-G41. [Also available at https://pubs.er.usgs.gov/ publication/wri914052.]

Stelten, M.E., Cooper, K.M., Vazquez, J.A., Calvert, A.T., and Glessner, J.J.G., 2015, Mechanisms and timescales of generating eruptible rhyolitic magmas at Yellowstone Caldera from zircon and sanidine geochronology and geochemistry: Journal of Petrology, v. 56, no. 8, p. 1,607-1,642. [Also available at https://doi.org/10.1093/petrology/egv047.]

Sturchio, N.C., Pierce, K.L., Murrell, M.T., and Sorey, M.L., 1994, Uranium-series ages of travertines and timing of the last glaciation in the northern Yellowstone area, WyomingMontana: Quaternary Research, v. 41, no. 3, p. 265-277. [Also available at https://doi.org/10.1006/qres.1994.1030.]

Suppe, J., Powell, C., and Berry, R., 1975, Regional topography, seismicity, and Quaternary volcanism, and the present-day tectonics of the western United States: American Journal of Science, v. 275-A, p. 397-436. [Also available at http://earth. geology.yale.edu/ ajs/1975/ajs_275A_1.pdf/397.pdf.]

Tauxe, L., Luskin, C., Selkin, P., Gans, P., and Calvert, A., 2004, Paleomagnetic results from the Snake River PlainContribution to the time-averaged field global database: Geochemistry, Geophysics, and Geosystems, v. 5, no. 8, 19 p. accessed at https://doi.org/10.1029/2003GC000661.

Tian, Y., and Zhao, D., 2012, P-wave tomography of the western United States-Insight into the Yellowstone hotspot and the Juan de Fuca slab: Physics of the Earth and Planetary Interiors, v. 200-201, p. 72-84, accessed at https://doi.org/10.1016/j. pepi.2012.04.004.

Till, C.B., Vazquez, J.A., and Boyce, J.W., 2015, Months between rejuvenation and volcanic eruption at Yellowstone Caldera, Wyoming: Geology, v. 43, no. 8, p. 695-698, accessed at http:// geology.gsapubs.org/content/43/8/695.

Thompson, J.M., Presser, T.S., Barnes, R.B., and Bird, D.B., 1975, Chemical analyses of waters of Yellowstone National Park, Wyoming, from 1965-1973: U.S. Geological Survey Open File Report 75-25, 59 p. [Also available at https://pubs.er.usgs.gov/ publication/ofr7525.]

Thompson, J.M., and Yadav, S., 1979, Chemical analyses of waters from geysers, hot springs and pools in Yellowstone National Park, Wyoming, from 1974-1978: U.S. Geological Survey Open-File Report 79-704, 49 p.
Truesdell, A.H., and Fournier, R.O., 1976, Conditions in the deeper parts of the hot spring systems of Yellowstone National Park, Wyoming: U.S. Geological Survey OpenFile Report 76-428, 29 p.

Truesdell, A.H., Nathenson, M., and Rye, R.O., 1977, The effects of subsurface boiling and dilution on the isotopic compositions of Yellowstone thermal waters: Journal of Geophysical Research Solid Earth, v. 82, no. 26, p. 3,694-3,704. [Also available at https://doi.org/10.1029/ JB082i026p03694.]

U.S. Geological Survey, 1972a, Surficial geologic map of the Yellowstone National Park: U.S. Geological Survey Miscellaneous Investigations Map I-710, 1 sheet, scale 1:125,000. [Also available at https://pubs.er.usgs.gov/ publication/i710.]

U.S. Geological Survey, 1972b, Geologic map of Yellowstone National Park: U.S. Geological Survey Miscellaneous Geological Investigations Map I-711, 1 sheet, scale 1:125,000. [Also available at https://pubs.er.usgs.gov/ publication/i711.]

U.S. Geological Survey, 1975, The Hebgen Lake, Montana, earthquake of August 17, 1959: U.S. Geological Survey Professional Paper 435, 340 p., 5 pls. [Also available at https://pubs.er.usgs.gov/publication/pp435.]

Vandemeulebrouck, J., Roux, P., and Cros, E., 2013, The plumbing of Old Faithful geyser revealed by hydrothermal tremor: Geophysical Research Letters, v. 40, no. 10, p. 1,989-1,993, accessed at https://doi.org/10.1002/ grl.50422.

Vandemeulebrouck, J., Sohn, R.A., Rudolph, M.L., Hurwitz, S., Manga, M., Johnston, M.J.S., Soule, S.A., McPhee, D., Glen, J.M., Karlstrom, L., and Murphy, F., 2014, Eruptions at Lone Star geyser, Yellowstone National Park, USA-2; Constraints on subsurface dynamics: Journal of Geophysical Research Solid Earth, v. 119, no. 12, p. 8,688-8,707, accessed at https://doi.org/10.1002/2014JB011526.

Vaughan, R.G., Keszthelyi, L.P., Lowenstern, J.B., Jaworowski, C., and Heasler, H.P., 2012, Use of ASTER and MODIS thermal infrared data to quantify heat flow and hydrothermal change at Yellowstone National Park: Journal of Volcanology and Geothermal Research, v. 233-234, p. 72-89. [Also available at https://doi.org/10.1016/j. jvolgeores.2012.04.022.]

Vaughan, R.G., Heasler, H., Jaworowoski, C., Lowenstern, J.B., and Keszthelyi, L.P., 2014, Provisional maps of thermal areas in Yellowstone National Park, based on satellite thermal infrared imaging and field observations: U.S. Geological Survey Scientific Investigations Report 2014-5137, 22 p., accessed at http://dx.doi.org/10.3133/sir20145137. 
Vazquez, J.A., Kyriazis, S.F., Reid, M.R., Sehler, R.C., and Ramos, F.C., 2009, Thermochemical evolution of young rhyolites at Yellowstone-Evidence for a cooling but periodically replenished post-caldera magma reservoir: Journal of Volcanology and Geothermal Research,

v. 188, nos. 1-3, p. 186-196. [Also available at https://doi. org/10.1016/j.jvolgeores.2008.11.030.]

Vazquez, J.A., and Reid, M.R., 2002, Time scales of magma storage and differentiation of voluminous high-silica rhyolites at Yellowstone Caldera, Wyoming: Contributions to Mineralogy and Petrology, v. 144, no. 3, p. 274-285. [Also available at https://doi.org/10.1007/s00410-002-0400-7.]

Waite, G.P., and Smith, R.B., 2002, Seismic evidence for fluid migration accompanying subsidence of the Yellowstone Caldera: Journal of Geophysical Research Solid Earth, v. 107, no. B9, 27 p. [Also available at https://doi. org/10.1029/2001JB000586.]

Waite, G.P., Smith, R.B., and Allen, R.M., 2006, $V_{P}$ and $V_{S}$ structure of the Yellowstone hot spot from teleseismic tomography - Evidence for an upper mantle plume: Journal of Geophysical Research Solid Earth, v. 111, no. B4, 21 p. [Also available at https://doi.org/10.1029/2005JB003867.]

Watts, K.E., Bindeman, I.N., and Schmitt, A.K., 2012, Crystal scale anatomy of a dying supervolcano-An isotope and geochronology study of individual phenocrysts from voluminous rhyolites of the Yellowstone Caldera: Contributions to Mineralogy and Petrology, v. 164, no. 1,

p. 45-67. [Also available at https://doi.org/10.1007/s00410-0120724-x.]

Wells, R., Bukry, D., Friedman, R., Pyle, D., Duncan, R., Haeussler, P., and Wooden, J., 2014, Geologic history of Siletzia, a large igneous province in the Oregon and Washington Coast Range - Correlation to the geomagnetic polarity time scale and implications for a long-lived Yellowstone hotspot: Geosphere, v. 10, no. 4, p. 692-719, accessed at https://doi. org/10.1130/GES01018.1.

Werner, C., and Brantley, S.L., 2003, $\mathrm{CO}_{2}$ emissions from the Yellowstone volcanic system: Geochemistry, Geophysics, Geosystems, v. 4, no. 7, p. 1,061, accessed at https://doi. org/10.1029/2002GC000473.

Werner, C., Brantley, S.L., and Boomer, K., 2000, $\mathrm{CO}_{2}$ emissions related to the Yellowstone volcanic system-2. Statistical sampling, total degassing and transport mechanisms: Journal of Geophysical Research, v. 105, no. B5, p. 10,831-10,846. [Also available at https://doi.org/10.1029/1999JB900331.]

White, D.E., Fournier, R.O., Muffler, L.J.P., and Truesdell, A.H., 1975, Physical results of research drilling in thermal areas of Yellowstone National Park, Wyoming: U.S. Geological Survey Professional Paper 892, 70 p. [Also available at https://pubs. er.usgs.gov/publication/pp892.]
White, D.E., Hutchinson, R.A., and Keith, T.E.C., 1988, The geology and remarkable thermal activity of Norris Geyser Basin, Yellowstone National Park, Wyoming: U.S. Geological Survey Professional Paper 1456, 84 p. [Also available at https:// pubs.usgs.gov/pp/1456/.]

White, D.E., Muffler, L.J.P., and Truesdell, A.H., 1971, Vapordominated hydrothermal systems compared with hot-water systems: Economic Geology, v. 66, no. 1, p. 75-97. [Also available at https://doi.org/10.2113/gsecongeo.66.1.75.]

Wicks, C., Thatcher, W., and Dzurisin, D., 1998, Migration of fluids beneath Yellowstone Caldera inferred from satellite radar interferometry: Science, v. 282, no. 5388, p. 458-462. [Also available at https://doi.org/10.1126/science.282.5388.458.]

Wicks, C., Thatcher, W., Dzurisin D., and Svarc, J., 2006, Uplift, thermal unrest and magma intrusion at Yellowstone Caldera: Nature, v. 440, p. 72-75. [Also available atn https://doi. org/10.1038/nature04507.]

Wilson, C.J., 2009, Physical volcanology of the Huckleberry Ridge Tuff [abs.]: Abstracts of Eos, Transactions American Geophysical Union 2009 Fall Meeting, San Francisco, Calif., Dec. 14-18, 2009, supplemental abstract no. V23C-2085, accessed at http://adsabs.harvard.edu/abs/2009AGUFM. V23C2085W.

Witkind, I.J., and Stickney, M.C., 1987, The Hebgen Lake earthquake area, Montana and Wyoming, in Beus, S.S., ed., Rocky Mountain Section of the Geological Society of America - Centennial field guide volume 2: Boulder, Colo., Geological Society of America, p. 89-94.

Wotzlaw, J-F., Bindeman, I.A., Stern, R.A., D’Abzac, F.X., and Schaltegger, U., 2015, Rapid heterogeneous assembly of multiple magma reservoirs prior to Yellowstone supereruptions: Scientific Reports, v. 5, article no. 14026, accessed at https://doi. org/10.1038/srep14026.

Yellowstone National Park, 2015, Yellowstone resources and issues handbook 2015: Yellowstone National Park, Wyo., $278 \mathrm{p}$.

Yellowstone Volcano Observatory, 2006, Volcano and earthquake monitoring plan for the Yellowstone Volcano Observatory, 2006-2015: U.S. Geological Survey Scientific Investigations Report 2006-5276, 17 p., accessed at https://pubs.usgs.gov/ sir/2006/5276/.

Yellowstone Volcano Observatory, 2010, Protocols for geologic hazards response by the Yellowstone Volcano Observatory: U.S. Geological Survey Circular 1351, 18 p., accessed at https://pubs.er.usgs.gov/publication/cir1351.

Yellowstone Volcano Observatory, 2014, Protocols for geologic hazards response by the Yellowstone Volcano Observatory (ver. 2.0, November 2014): U.S. Geological Survey Circular, 1351, 16 p. [Also available at https://pubs. usgs.gov/circ/1351/.] 
Yokochi, R., Sturchio, N.C., Purtschert, R., Jiang, W., Lu, Z.T., Mueller, P., Yang, G.M., Kennedy, B.M., and Kharaka, Y., 2013, Noble gas radionuclides in Yellowstone geothermal gas emissions - A reconnaissance: Chemical Geology, v. 339, p. 43-51, accessed at https://doi.org/10.1016/j. chemgeo.2012.09.037.

Yuan, H., and Dueker, K., 2005, Teleseismic $P$-wave tomogram of the Yellowstone plume: Geophysical Research Letters, v. 32, no. 7, article no. L07304, 4 p. [Also available at https://10.1029/2004GL022056.]
Zinder, S., and Brock, T.D., 1977, Sulfur dioxide in geothermal waters and gases: Geochimica et Cosmochimica Acta, v. 41, no. 1, p. 73-79. [Also available at https://doi.org/10.1016/00167037(77)90187-9.] 


\section{Appendix}

\section{What You Need for the Field Trip}

While this field trip is being held in summer months, weather here can be quite variable. It is important to bring warm clothing, rain gear, and good hiking shoes. Participants also will want to bring, in addition to their provided box lunch, ample water, snacks, extra socks, and sunscreen and other sun protection such as a hat. Most of our time will be spent outdoors regardless of the weather (rain or sunshine). You should be prepared for a variety of mountain weather conditions and temperatures, anywhere from below freezing in the mornings to $85^{\circ} \mathrm{F}$ in the afternoons. Appropriate clothing, equipment, and footwear are very important. The layered use of garments for protection against the wind, sun, and temperature extremes should guide your clothing choices. Loose fitting layers allow you to maintain a comfortable and dry body as outside temperatures change and as your own body's temperature and moisture output changes with different levels of exertion. Some of the colder-weather items may not be needed in August at the time of field trip but keep in mind that Yellowstone's weather is unpredictable. You are required to bring the following items and clothing with you during the field trip:

- Daypack - This should have enough capacity to carry extra clothes, water, lunch, camera, binoculars, field guides, etc.

- Water bottle - One quart size is the minimum recommended. Camelback or similar hydration systems work well in summer but can freeze in winter.

- Sunglasses

- Sunscreen and lip protector-The Sun at high altitude can burn unprotected skin quickly.

- Camera

- Binoculars

- Notebook

- Pencils

- Summer clothing

- Insulating underwear-Made of capilene, polypropylene, or similar wicking fabric.

- Midweight insulating layer-A light 200-weight synthetic fleece, wool shirt, or pullover.
- Heavyweight insulating layer-Made of wool; or a down or heavy-weight fleece jacket for less active times.

- Waterproof and windproof outer layer-Should be lightweight and breathable; jackets and pants are recommended.

- Short sleeved shirt - Cotton is fine in the summer, but synthetic wicking shirts are ideal.

- Pants or trousers - Hiking pants, lightweight pile or fleece pants, or tights.

- Hats - Bring both a brimmed sun hat and an insulating hat for cool weather.

- Gloves-Bring lightweight glove liners, and a pair of wool or fleece gloves or mittens.

\section{Hiking Conditions and Safety Precautions on the Field Trip}

Each day, we will hike 2 to 8 miles ( $\sim 3.2$ to $12.9 \mathrm{~km}$ ) mostly on trails or boardwalks. Much of the landscape we will be hiking is undulating; elevation gains in individual hikes may be as much as 985 feet $(\sim 300 \mathrm{~m})$. Participants also should be aware of the high elevation of the Yellowstone Plateau, which averages $\sim 8,200$ feet $(\sim 2,500 \mathrm{~m})$ above sea level.

Our hikes will lead us through terrains inhabited by a variety of species, including grizzly and black bear, bison, wolves, elk, and deer, etc. Please do not approach any wildlife and stay at safe distances recommended by the National Park Service. Visitors should take full recommended precautions to avoid conflicts with wildlife.

Care should be taken in approaching any backcountry thermal area; most are very hot and acidic and also require traversing bear- and bison-frequented terrain. Visitors should take full recommended precautions to stay on boardwalks and established trails to ensure personal safety and the preservation of delicate thermal features. Many hikes also will be in hot and acidic areas, so please stay on the boardwalk or trail. These areas are very prone to having thin sinter crusts and can be extremely dangerous and are potentially lethal.

It is against the law to collect rock, flower, plant, animal, soil, water, or any substance from Yellowstone National Park without a pre-approved permit. 
Menlo Park Publishing Service Center, California Manuscript approved July 3, 2017

Edited by David Shields

Layout by Cory Hurd 


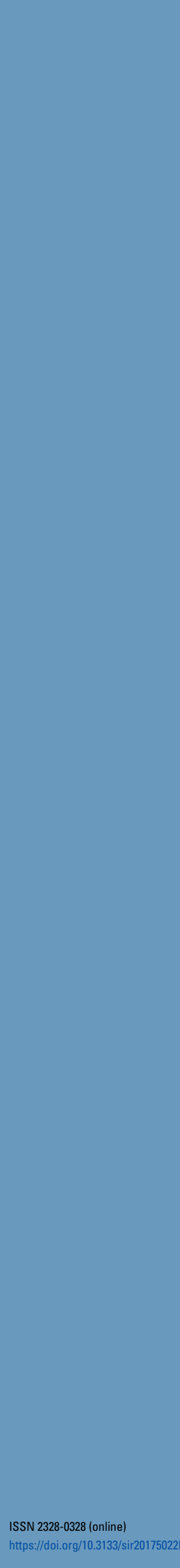

